\title{
Circos e palhaços brasileiros
}

\author{
Mario Fernando Bolognesi
}

BOLOGNESI, MF. Circos e palhaços brasileiros [online]. São Paulo: Cultura Acadêmica; São Paulo: Editora UNESP, 2009. 250 p. ISBN 978-85-7983-021-1. Available from SciELO Books <http://books.scielo.org>.

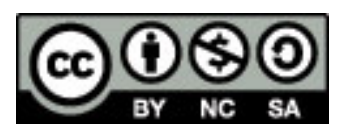

All the contents of this chapter, except where otherwise noted, is licensed under a Creative Commons Attribution-Non Commercial-ShareAlike 3.0 Unported.

Todo o conteúdo deste capítulo, exceto quando houver ressalva, é publicado sob a licença Creative Commons Atribuição - Uso Não Comercial - Partilha nos Mesmos Termos 3.0 Não adaptada.

Todo el contenido de este capítulo, excepto donde se indique lo contrario, está bajo licencia de la licencia Creative Commons Reconocimento-NoComercial-CompartirIgual 3.0 Unported. 


\section{Circos E PALHAÇOS BRASILEIROS}



MARIO FERNANDO BOLOGNESI

\author{
Circos E \\ PALHAÇOS \\ BRASILEIROS
}

CULTURA

$\frac{\text { ACADÊMICA }}{\varepsilon d i t o n a}$ 
(C) 2007 Editora UNESP

\section{Cultura Acadêmica}

Praça da Sé, 108

01001-900 - São Paulo - SP

Tel.: (0xx11) 3242-7171

Fax: (0xx11) 3242-7172

www.editoraunesp.com.br

feu@editora.unesp.br

CIP - Brasil. Catalogação na fonte

Sindicato Nacional dos Editores de Livros, RJ

B675c

Bolognesi, Mario Fernando

Circos e palhaços brasileiros / Mario Fernando Bolognesi. - São Paulo : Cultura Acadêmica, 2009.

il.

Inclui bibliografia

ISBN 978-85-7983-021-1

1. Palhaços - Brasil - História. 2. Circos - Brasil - História. 3. Representação teatral. 4. Aprendizagem. I. Título.

09-6218.

CDD: 791.330981

CDU: $791.8(81)$

Este livro é publicado pelo Programa de Publicações Digitais da Pró-Reitoria de Pós-Graduação da Universidade Estadual Paulista "Júlio de Mesquita Filho" (UNESP)

Editora afiliada:

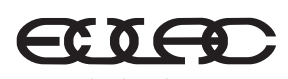

Asociación de Editoriales Universitarias de América Latina y el Caribe

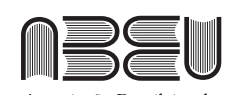

Associação Brasileira de Editoras Universitárias 


\section{SUMÁRIO}

Uma palavra inicial 7

1 Circo di Roma 9

2 Circo Astley 19

3 Circo Real 25

4 Circo Brother's 37

5 Super Circo Bira 45

6 Circo Vostok 51

7 Circo Real Argentino

57

8 Circo Sandriara 59

9 Circo Beto Carrero 65

10 Circo Brasil $2000 \quad 77$

11 Circo Roger 81

12 Circo Spacial 85

13 Circo di Napoli 93

14 Circo Weber 97

15 Circo Miami $2000 \quad 101$

16 Circo Garcia 107

17 Circo Xangai 117

18 Circo di Monza - Teatro Biriba/Geraldo 125 
19 Circo Maravilha 135

20 Teatro Biriba/Adriano

21 Teatro Serelepe 153

22 Teatro Bebé 161

23 Teatro Popular de Curitiba Piska-Piska 169

24 Circo di Mônaco 177

25 Circo Balão Mágico 181

26 Garden Circo 185

27 Circo Gitano 191

28 Pop Circo 197

29 Circo Raniere 201

30 Circo Mágico Alakazan II 205

31 Circo Washington 207

32 Circo de Las Vegas 213

33 Circo Pallesty Itália 217

34 Circo Real Bandeirantes 221

35 Circo Estrela 227

36 Circo Shalom 231

37 Parque Circo Las Vegas 237

38 Circo Rostok 241

Para finalizar... 249 


\section{UMA PALAVRA INICIAL}

Circos e palhaços brasileiros apresenta, em forma de catálogo, documentação iconográfica e escrita de alguns circos brasileiros e seus palhaços. De outubro de 1997 a julho de 2000, foram visitados diversos circos, em várias regiões do País, com o objetivo de documentar parte dos circos brasileiros e os diversos momentos dos palhaços, dentro e fora do picadeiro, além de resgatar o repertório cênico dos palhaços, envolvendo reprises, entradas, esquetes, comédias e dramas.

As várias faces do circo brasileiro têm, aqui, um pequeno registro, envolvendo basicamente os recursos materiais dos circos, contrastantes entre si (pequenos e grandes). O trabalho dos palhaços sob a lona também recebeu a devida atenção, envolvendo as mais variadas formas: palhaços que tiveram seu aprendizado no circo-teatro, os chamados palhaços de palco; os tapa-buracos dos circos grandes; o destaque do palhaço nos espetáculos dos pequenos circos; as quantidades e qualidades do repertório encenado; as opiniões dos artistas acerca da profissão etc.

Obviamente, nem todos os circos e palhaços brasileiros estão aqui registrados - tarefa impossível de ser realizada, quer seja pelas dimensões continentais deste País, quer seja pelo desconhecimento do número aproximado de companhias circenses que percorrem as mais 
diversas regiões do Brasil, ou mesmo pelos limites orçamentários para as viagens.

Alguns circos visitados e incluídos neste catálogo encerraram suas atividades ou alteraram o nome. $\mathrm{O}$ mesmo ocorre com os palhaços: alguns morreram, outros abandonaram a profissão, muitos trocaram de companhia etc.

Todo o trabalho de coleta, seleção e organização do material empírico foi realizado com a colaboração de alunos da Unesp, especialmente, Rodrigo Sampietro Leme, que, antes de estudante universitário, era circense, Alessandra Ortigosa Aro, Iara Toledo de Assis Bastos, Andrea Aparecida Pantano, Leonardo Rogério Mussi e Milene Valentir Ugliara. Além dos alunos, Kiko Roselli acompanhou boa parte das viagens com a preocupação exclusiva de captar imagens fotográficas dos circos e palhaços. Silvana, Marcelo e Hugo, além do estímulo afetivo, transformaram-se em auxiliares da pesquisa, por ocasião da viagem ao Nordeste.

Agradecimentos especiais merecem todos os artistas que partilharam seus saberes e experiências. A gratidão também se estende aos colegas da Universidade Estadual Paulista, que sempre incentivaram essas andanças. Os professores Vendramini, Neyde, Dilma, Reynuncio e Claude têm destaque especial nessa trajetória, pois foram os primeiros a avaliar parte significativa dos resultados da pesquisa.

Por fim, vale lembrar que toda a pesquisa não seria viável sem o auxílio financeiro da Fundação de Amparo à Pesquisa do Estado de São Paulo (Fapesp) e do Conselho Nacional de Desenvolvimento Científico e Tecnológico (CNPq). A edição deste catálogo só foi possível graças ao Prêmio Funarte Carequinha de Estímulo ao Circo 2007, Módulo Pesquisa. 


\section{1 \\ CIRCO DI ROMA}

O Circo di Roma foi visitado duas vezes. Na primeira, em agosto de 1997, na cidade de Marília-SP; a segunda, em Palmeira das Missões-RS, em 30 de janeiro de 1999.

O circo era grande, com boa estrutura física e muitos recursos sonoros e de iluminação. O primeiro espetáculo assistido foi de grande diversidade, com artistas que demonstraram perícia técnica, porém carentes de melhor acabamento nos números, tais como uma coreografia melhor trabalhada, um figurino de realce e melhor integração entre movimento e música.

Na segunda vez, no Sul do país, o encontro foi casual. Em Quilombo-SC, foi encontrado o Circo Xangai. Os contatos com as prefeituras da região indicavam que a viagem deveria prosseguir para a cidade de Coronel Martins, em busca do Circo Teatro Brasil e, depois, para Palmeira das Missões, ao encontro do Biriba. Nada ocorreu como planejado.

O caminho de Quilombo para Coronel Martins não era asfaltado, com aproximadamente 40 quilômetros de região serrana. O tempo estava chuvoso. O itinerário foi alterado e a viagem tomou o rumo de Palmeira das Missões, no Rio Grande do Sul, um percurso de 210 quilômetros. Pelas informações obtidas na prefeitura local, Biriba estaria em Palmeira das Missões. Porém, ali chegando, foi encontrado o Circo di Roma. 
O Circo di Roma foi, então, visitado pela segunda vez. O contato com o Roma também elucidou o paradeiro do Biriba: estava em Redentora, uma pequena cidade a 40 quilômetros de Palmeira das Missões.

\section{Primeiro espetáculo: Marília (SP)}

Primeira parte: Pêndulo; Clowns musicais; Pombas amestradas; Acrobacia com facas e bolas; Chevrolé e Parafuso em "Os atiradores de facas"; Bicicleta; Equilibrismo de bolas; Urso amestrado; Chevrolé e Parafuso em "O salto mortal na escada com a lata na mão"; Malabares.

Segunda parte: Trapézio Voador, com a participação do palhaço Chevrolé; Chevrolé e Parafuso em "A magia com patos"; Rola-rola; Corda indiana; Volteio; Pôneis amestrados; Elefante; Globo da Morte; Apoteose.

\section{Segundo espetáculo: Palmeira das Missões (RS)}

Primeira parte: Trapézio Voador, com a participação do palhaço Chevrolé; Chevrolé e Parafuso em "O salto mortal na escada com a lata na mão"; Laços e chicotes; Chevrolé e Parafuso em "O namoro dos palhaços"; Bambolê; Malabares.

Segunda parte: Double trapézio; Cavalo amestrado; Chevrolé e Parafuso em "A magia com patos"; Pôneis amestrados; Trapézio em Balanço; Corda indiana; Elefantes.

\section{Chevrolé}

Os palhaços eram os mesmos nos dois espetáculos: Chevrolé e Parafuso. Chevrolé participou do trapézio. A trupe de voos era composta de três elementos apenas, o aparador, um volante e o palhaço. 

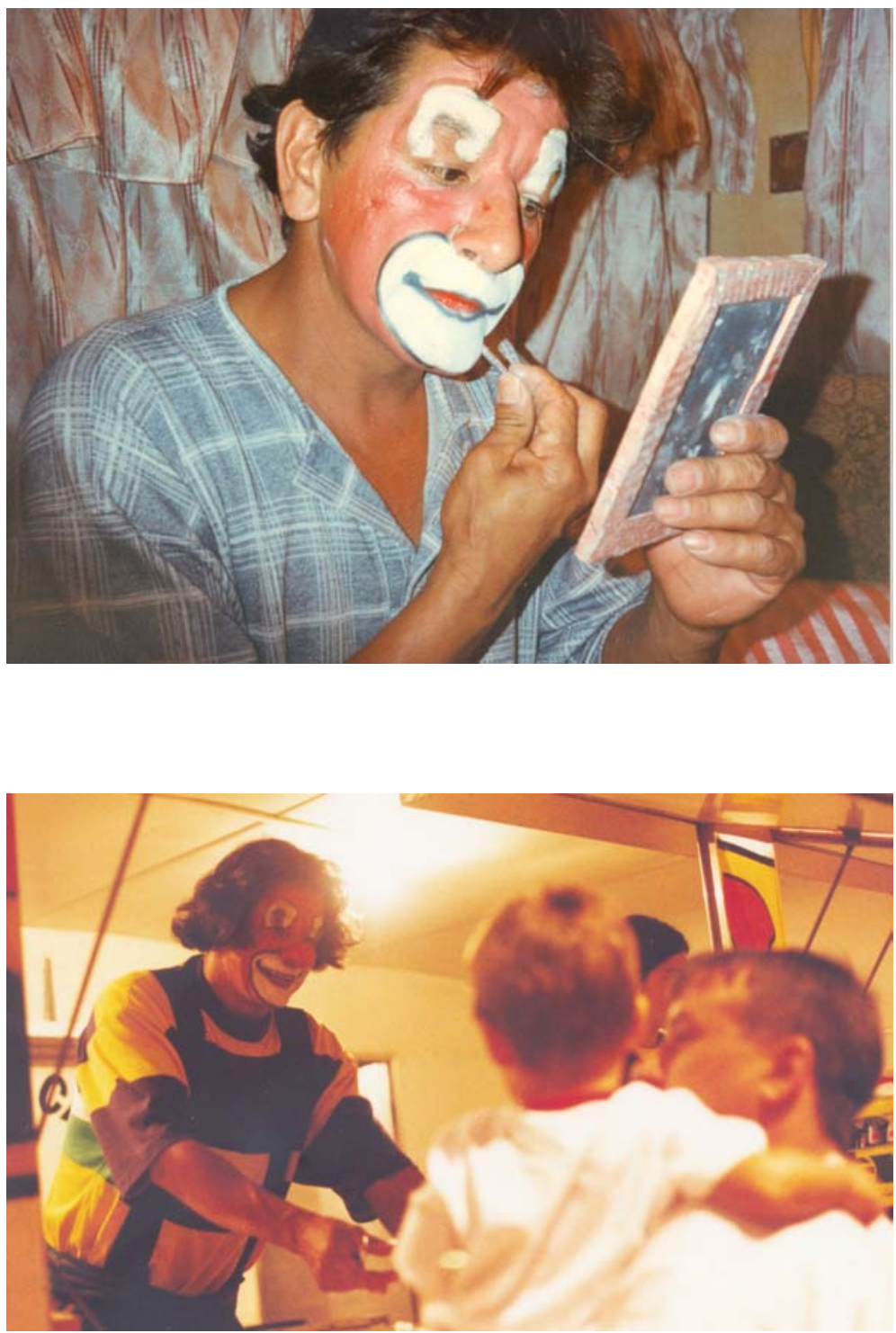
12 MARIO FERNANDO BOLOGNESI

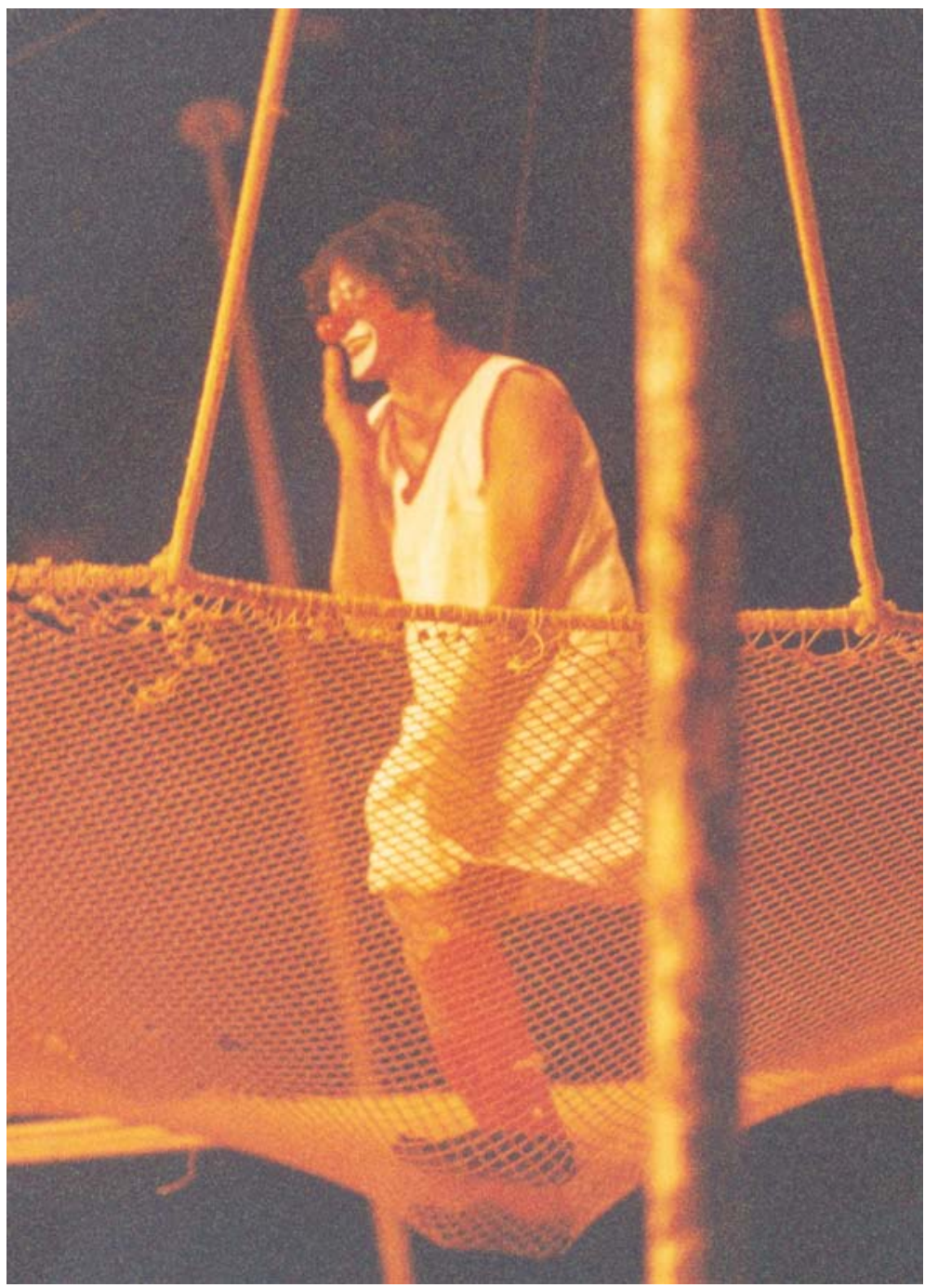


Na primeira iniciativa, Chevrolé preparou uma passagem para as mãos do aparador, o que não acontece. Na segunda vez, ele vacilou e o aparador arrancou-lhe as calças. Envergonhado, ele caiu na rede de proteção, procurando esconder suas "partes íntimas".

No picadeiro, os palhaços levaram as seguintes reprises: "O salto mortal na escada com a lata na mão", "Namoro dos palhaços" e "A magia com patos". A primeira e a última foram apresentadas em ambas as cidades. Coincidência? Repertório escasso? Ambas as alternativas. O repertório de entradas e reprises levado à cena, ao qual se pôde assistir, fotografar e registrar, não é, de fato, muito variado. No geral, as reprises resumem-se a roteiros e situações cômicas, quase sempre envolvendo números e personagens do próprio espetáculo circense. Exemplo: "O salto mortal" é uma paródia de uma evolução clássica no espetáculo circense: a maioria dos números envolvendo acrobacia, de um modo ou de outro, tem em seu repertório o salto mortal. A paródia recai unicamente sobre o palhaço e sua inca-
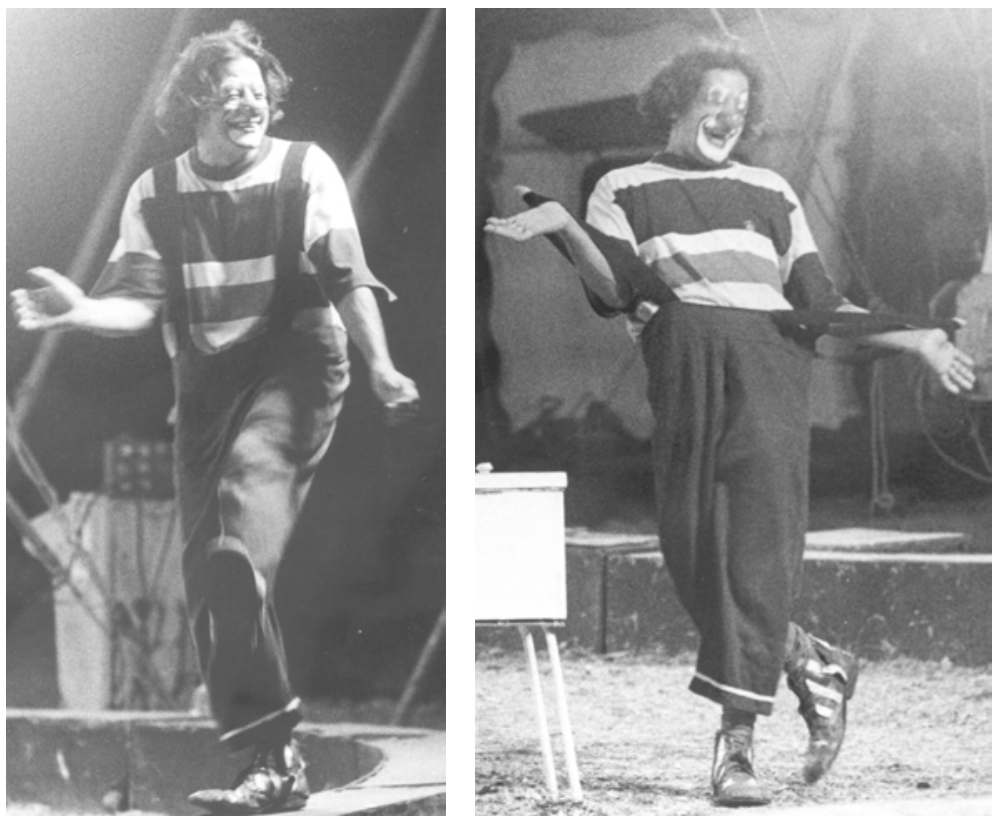
pacidade de realizar uma proeza acrobática. O cômico, nesse caso, não remete ao exterior: ele se volta sobre si mesmo, ou melhor, tem como centro a performance do palhaço. De resto, o sucesso de uma entrada ou reprise depende diretamente da qualidade da interpretação. A seguir, Chevrolé em "A magia com patos" e "Namoro dos palhaços”, encenadas em Palmeira das Missões-RS.

Os palhaços Chevrolé e Parafuso, com roupas bastante folgadas e coloridas, apresentaram-se nos intervalos de preparação da pista para novos números. Por exemplo, na primeira parte do espetáculo visto em Marília-SP, na reprise "Os atiradores de facas", enquanto eles se apresentavam a pista era preparada para o número de bicicletas, que necessitava de um grande tablado de madeira para a evolução do artista. Na segunda parte, enquanto se desmontava a rede do trapézio voador, Chevrolé e Parafuso, com a participação do apresentador, encenavam "A magia com patos". Apenas com "O salto mortal na escada com a lata na mão”, os palhaços não se sobrepuseram à movimentação dos preparadores de pista e aparelhos.

A outra entrada apresentada por Chevrolé e Parafuso, em Palmeira das Missões-RS, "O namoro dos palhaços", uma adaptação de "O namoro dos pássaros", ficou muito conhecida na interpretação de Piolim. Dois palhaços fantasiados de pássaros, com um pequeno instrumento na boca, simulam uma cena de conquista amorosa em que o macho, insistentemente, tenta conquistar a fêmea. Sem uma única palavra, ela é permeada de gestos com referências ao ato sexual ou mesmo aos órgãos genitais. Chevrolé e Parafuso adaptaram a situação para os próprios palhaços. Parafuso estava travestido de mulher, com saiote e sutiã.

A movimentação cênica e a expressão corporal vêm a ser as características básicas desse tipo de entrada. A precisão gestual se faz necessária e, na apresentação de Chevrolé e Parafuso, não houve recorrência a uma ação interiorizada, de ordem psicológica. Ao contrário, a ação física era propositalmente trabalhada em sua forma grandiosa, dando realce e graça à interpretação. Os gestos eram preparados aos poucos, em um crescendo, até culminar em um instante de congelamento, espécie de síntese do enredo, ou de parte dele ao menos. 
As fotos de Kiko Roselli exemplificam a interpretação exteriorizada, que sintetiza boa parte do trabalho dos palhaços brasileiros.

\section{Entrevista}

Chevrolé é criação de Sidney Kikuchi. O nome da personagem advém de sua paixão por carros. Quando entrevistado, em 1997, ele tinha 40 anos de idade e dezoito como palhaço. Nasceu em Sertanópolis-PR, no Circo Windsor, onde sua mãe trabalhava. Atuou em circos grandes, médios e pequenos, no Brasil e no exterior.

Eu fazia trapézio - ainda continuo fazendo. Antigamente, eu fazia vários números. Como a minha família já vem de tradição, então você aprende muito, de tudo o que tem dentro de um circo. Fiz um número de cesto do abismo, fiz o pêndulo, número de equilíbrio de cinco rolos, já fiz perna-de-pau... Você tem que ser como um curinga dentro do circo.

Eu nunca tinha pensado em ser palhaço, foi uma casualidade. Nós íamos estrear em Belo Horizonte, no circo de um tio meu, que chama hoje Circo Italiano. No dia da estreia, tinha dois anõezinhos no circo (os dois palhaços eram dois anões) e um deles discutiu com meu tio. Meu tio mandou ele embora, e ia pintar o rosto pra trabalhar de palhaço. Nós éramos quatro primos no circo. Meu tio fez uma aposta: qual de nós quatro queria trabalhar de palhaço à noite, entendeu?!... Com ele e com o anão. E meu tio ainda falou: "Qualquer um dos quatro que fizer isso eu vou pagar a semana todinha e vou levar no melhor clube e deixar vocês dançarem e eu pago toda a despesa". E, como éramos muito bagunceiros, todos nós aceitamos a proposta. Aí, eu me pintei à noite pra trabalhar e os outros meus primos de vergonha não pintaram. Eu pintei e fiquei esperando meu tio chegar. Quando meu tio chegou, ele falou: "Eu vou fazer isso, isso..." Como a gente já conhecia todas as entradas de circo, desde pequeno, a gente já sabia mais ou menos o que tinha que fazer lá dentro. Quer dizer, a gente não ia fazer vexame. O vexame meu maior foi quando eu perdi a voz. A minha vergonha foi tão grande no impacto, que eu 
16 MARIO FERNANDO BOLOGNESI
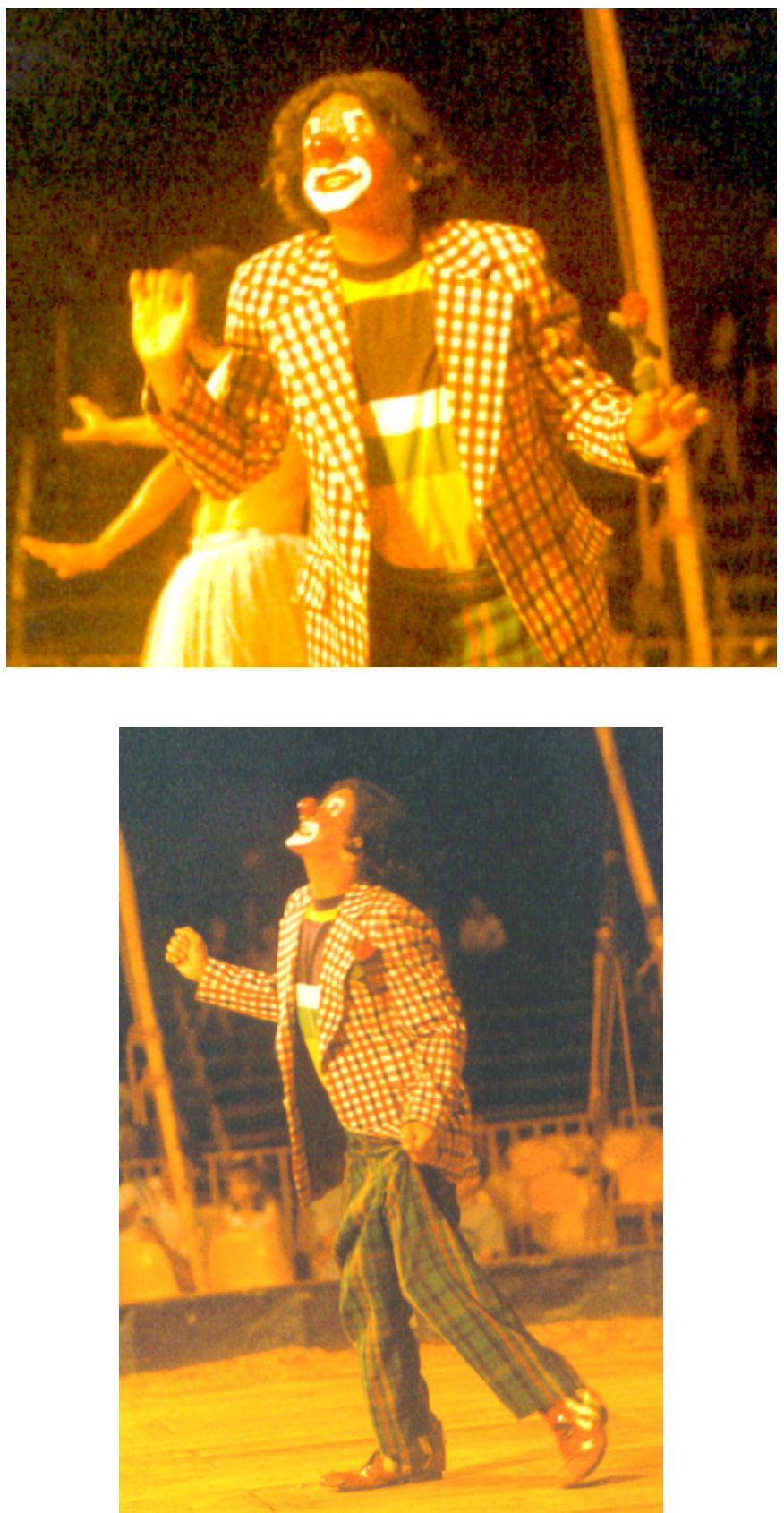
perdi a voz, mas mesmo tendo perdido a voz eu trabalhei mais com a fisionomia, com caricaturas, com gestos, com a mímica do corpo. Então, foi onde eu me saí bem, foi onde meu tio gostou, meus parentes todos que tinham assistido gostaram e eles acharam que no lugar de eu fazer os números, que eu tinha que optar por palhaço, que eu tinha todo o dom pra aquilo, mesmo sem falar.

Meu personagem... eu vou explicar pra você. Eu, na época que eu comecei a trabalhar de palhaço, eu tinha vergonha. Eu era um moleque novo e, sabe como é, toda a vaidade de moleque novo... Você não quer aparecer pra moça com a caricatura de palhaço que a pessoa vai te reconhecer na rua, dentro de um clube, de um bar... tinha vergonha disso. Então, procurei fazer uma caricatura (pintura) no meu rosto, grande, para que ninguém me reconhecesse. Tirei um pouco de um palhaço antigo, de outro... Então, fiz a minha maquiagem grande no rosto e usava peruca, só que atualmente eu não uso mais peruca porque acabou a vergonha... Hoje em dia, já não requer mais o estilo, por causa do trapézio, então não dá mais pra usar peruca. E as roupas minhas, eu bolei um estilo que me deixasse menor no picadeiro, quer dizer, eu tenho uma estatura de quase 1,75 m, então bolei um estilo de roupa que, no palco, dá a impressão que eu sou um pouco mais baixo. Sempre um pouco mais justa pra dar a impressão que eu sou menor.

Eu tento transmitir para o público alegria, nunca tristeza, entendeu?! Porque o palhaço quando é triste, transmite tristeza e se vocêé um palhaço alegre, logicamente você vai transmitir alegria. O palhaço, sempre que leva um tapa, tem que cair, rir, levantar e rir outra vez. Não existe palhaço que tem lágrima, fisionomia de choro, expressão de tristeza. Eu acho que isso não atrai, o que atrai é a imagem do palhaço fazer sorrir, nunca tristeza.

Quando eu entro pra trabalhar eu olho todo o público. Porque tem público que você usa coisas picantes, piadas picantes, gestos picantes. Outros, não gostam, já acham vulgar. Então, você tem que trabalhar nos dois termos: você tem que trabalhar no termo limpo, como a gente diz, e no termo sujo, porque existe um nível de público pra tudo, entendeu? O público de elite já não gosta de gesto porno- 
gráfico, agora o público de vilas já gosta. Você sabe que é o circo o único que junta toda a sociedade, classe baixa, média, alta... é a única diversão que junta todos ao mesmo tempo.

O melhor improviso é aquele que você tira de última hora, sabia?

O palhaço, atualmente, é difícil se criar: se copia, mas cada um copia num estilo diferente um do outro. Eu procurei copiar todas as cenas minhas de coisas antigas, de coisas de palhaços antigos, eu procurei copiar para mim no meu estilo de trabalho, que combinasse com meu jeito de ser também no picadeiro, porque tem muitas cenas de palhaço que eu tenho guardado, mas não faço porque para mim não orna, eu guardo, mas eu guardo com todo o carinho, porque eu sei que uma hora eu vou precisar, não é mesmo? Antigamente, existia o palhaço clown, que é aquele palhaço que fazia aquela caricatura toda branca no rosto e atendia o outro palhaço que vinha com a maquiagem normal de palhaço. Hoje em dia não tem: é muito raro você ver isso. 


\section{2 \\ Circo Astley}

\section{O espetáculo}

Primeira parte: Arame bambo; Faísca em "O caveirão"; Corda indiana; Equilibrismo cômico.

Segunda parte: Show dos anões Irmãos Vieira.

O Circo Astley, cujo nome lembra o criador do circo moderno, Philip Astley, era pequeno. Sua lona principal, de 22 metros x 28

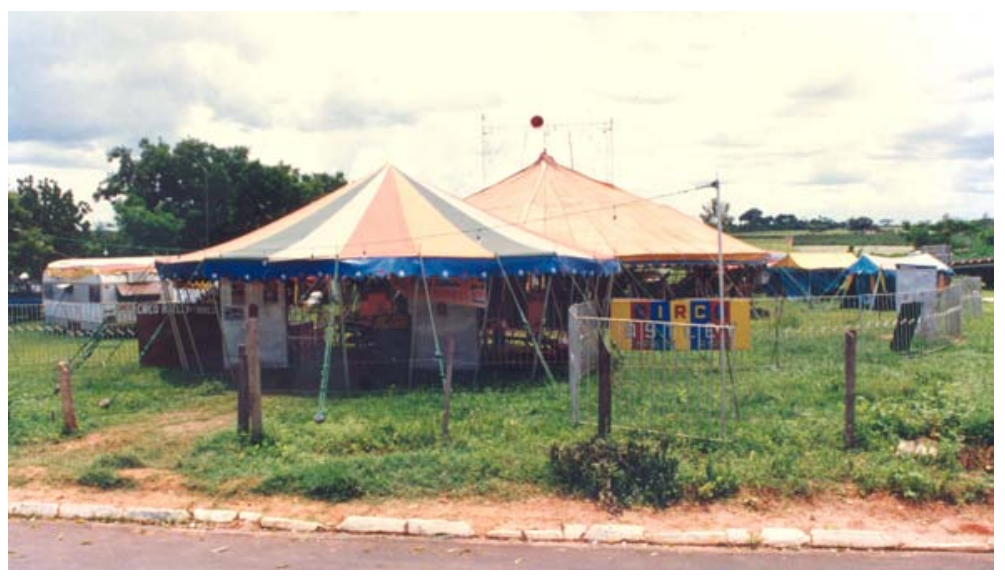




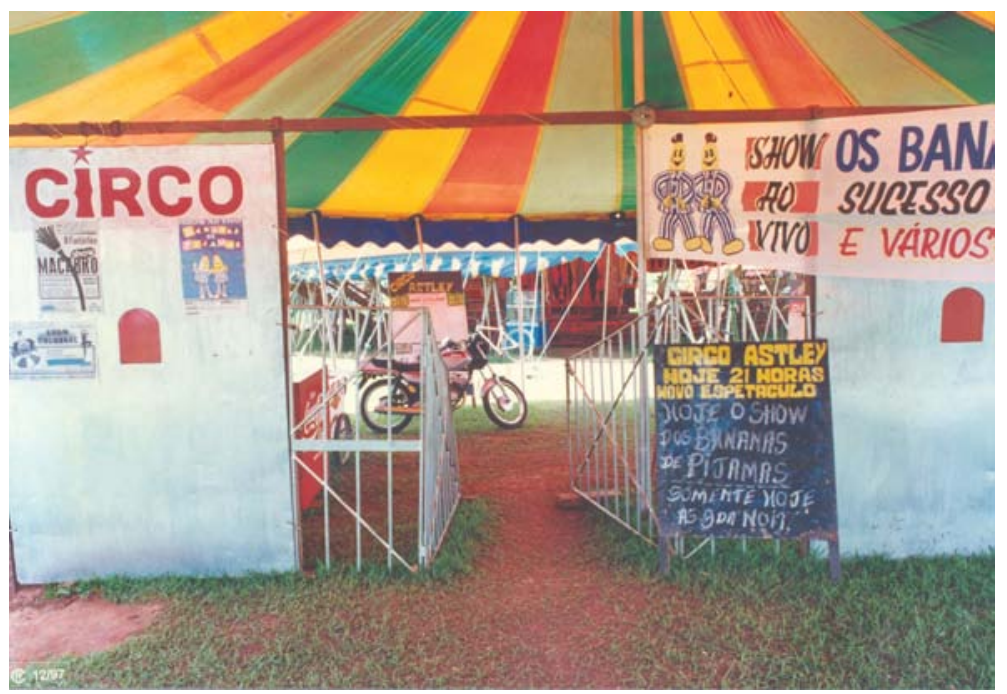

metros, era suportada por dois mastros. Internamente, um palco e um picadeiro, ambos reduzidos, serviam de espaço cênico. $O$ público acomodava-se em arquibancadas, bancos e cadeiras. Os equipamentos de sonorização e iluminação eram bastante precários.

O espetáculo do Circo Astley, visitado em 11 de dezembro de 1997, na cidade de Nova Aliança-SP, foi bastante reduzido, na primeira parte. Poucos números foram apresentados. Na segunda parte, ocorreu o show musical com os Irmãos Vieira, dois anões, que cantaram, dançaram, brincaram com a plateia e desafiaram os homens para uma medição de forças.

\section{Faísca}

Abílio da Silva Júnior, o palhaço Faísca, nasceu em 18 de agosto de 1953, em um circo. A família dedicava-se ao circo-teatro, desde a década de 1920. Assim, frequentou o palco desde pequeno. Sua estreia no ofício cômico se deu aos 16 anos de idade.

$\mathrm{O}$ nome da personagem sugere velocidade e rapidez. Sua maquiagem era bastante simples, com pequenos traços brancos nos 

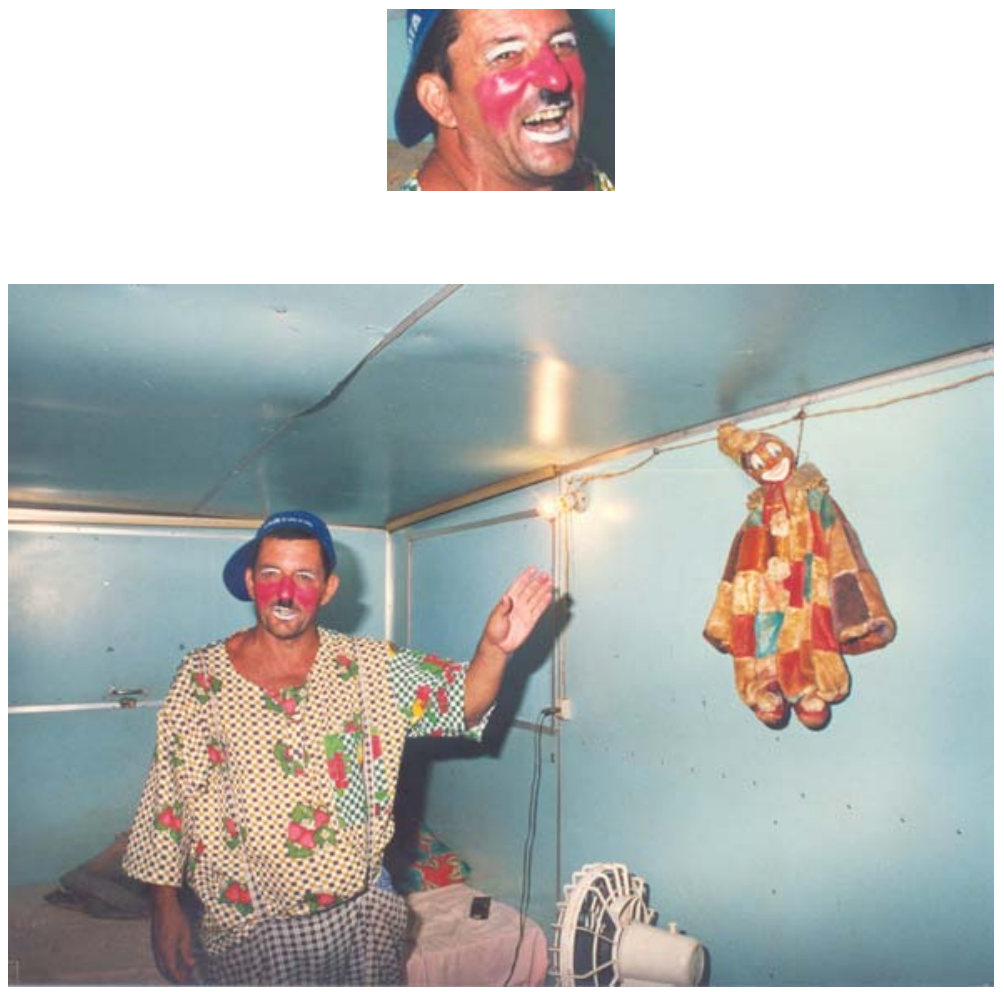

lábios e nos olhos e uma grande mancha vermelha que cobria as duas bochechas. O nariz era igualmente vermelho e exuberante. Uma peruca prolongava a testa branca, fazendo com que o rosto ganhasse proporções inusitadas.

Embora tenha participado de quase todo o espetáculo, em apenas uma oportunidade pôde-se apreciar as destrezas cênicas do artista, na entrada "O caveirão". Esta entrada não deposita a graça no recurso linguístico. Antes, requer um razoável desempenho interpretativo para atingir seu intento. Há, de fato, uma contraposição entre a história que o palhaço "corajoso" relata e seu desmentido a partir das reações corporais, diante de um fantasma que entra em cena. Faísca optou por uma trucagem da peruca para salientar seu espanto diante do monstro. 
Além de palhaço, Faísca também era o apresentador do espetáculo. Ou seja, esteve em cena praticamente todo o tempo. Na segunda parte, reservada aos Irmãos Vieira, ele também participou ativamente da performance dos anões.

\section{Entrevista}

Hoje, infelizmente, eu não posso levar uma entradinha que nãoé picante na matinê, que a molecada não ri. Você tem que apelar. A criançada já vê, já vem sabendo mais que a gente. Antigamente, todas as entradas de matinê eram bem levinhas. Hoje, não: você tem que pôr, tem que atacar eles um pouco, porque senão...

Sou palhaço sem querer... O Pouca Roupa, o mais velho, o João, ia estrear o circo. Então, ele fazia passeio, facas, fazia quatro, cinco números, aí ele falou: "Mas eu preciso de um intervalo, alguma coisa”. E eu sempre gostei de teatro, eu só trabalhei em teatro, num queria pôr eu no picadeiro, que eu fugia, eu fugia mesmo, me escondia. Apanhava do meu tio. Aí o João falou: "Cê vai fazer palhaço, pra me dar um intervalo!" Eu falei: "Não sei fazer isso não”. Aí, chegou de noite, ele mesmo arrumou uma roupa, pintou minha cara, e falou: "Olha, enquanto eu termino o passeio pra depois fazer as facas, você vai fazer..., e leva a entrada de palhaço". E ele me empurrou e eu fui mesmo. Aí, eu tive que fazer, e depois eu gostei, e até hoje eu gosto, é uma das coisas que eu adoro fazer, não tanto de picadeiro, mas de palco eu gosto. Quando eu faço palhaço de palco eu me sinto mais à vontade.

Eu apelo muito pra política. Porque o palhaço é isso: ele não pode viver apenas do passado. Você tem que usar coisas que o povo fala na rua, coisas de televisão, livro, jornal... O palhaço tem que ler, ser informado, ele tem que ter uma relação pública com o povo, tem que saber dos acontecimentos da cidade. Em Fernando Prestes, aconteceu um caso meio gozado. Um senhor, João Camargo, que foi prefeito várias vezes, presidente da Câmara, ele tinha um peru de estimação. A turma foi lá, fez uma batucada na porta da casa dele, pra 


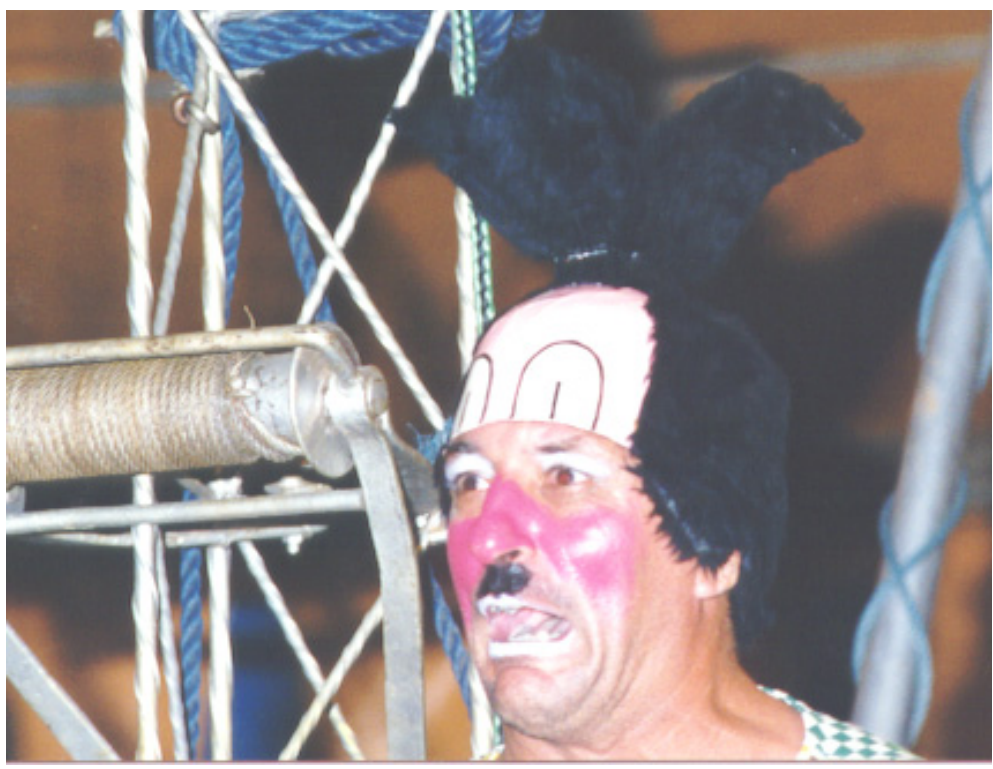

chamar a atenção, e foram pelo fundo e roubaram o peru. Levaram o peru pro rio e deram um fogo no peru; tomaram um fogo e deram um fogo no peru; o peru bêbado e eles bêbados. Depenaram o peru vivo e enfeitaram a caminhonete com pena e foram buscar mais pinga na cidade. Isso já eram 6 horas da manhã, e o João Camargo andando na cidade atrás do peru. Ele viu as penas do peru na caminhonete e achou o peru. Foi todo mundo na delegacia, todo mundo preso, virou um rebu na cidade. $\mathrm{E}$ eu, quando cheguei, me contaram. O circo cheio, aí meu irmão falou: "Oh, graças a Deus que ele morreu! Esse é ladrão de galinha!”. Aí, eu falei: "Pode parar. Ladrão de galinha não: eu roubo peru do João Camargo!”. O circo detonou: o povo ficou rindo quase vinte minutos. A gente usa o que acontece na cidade, eu gosto de ficar me informando na cidade de uma coisa e de outra. Eu vivo pra cidade, no bar, nas lanchonetes, em todo lugar, pra saber o que acontece. 



\section{3 \\ Circo Real}

\section{Os espetáculos}

\section{Ariranha}

Bochechinha em "O caçador e o piano"; Show musical, com paródias do palhaço Piquito; Drama, "O ébrio”, com Piquito.

\section{Embaúba}

Monociclo; Adagas; Chicotes e laços; Show musical, com paródias do Piquito; Comédia, "O macumbeiro", com Piquito.

O Circo Real foi visitado em três oportunidades, nas cidades de Agulhas-SP, em 13 de fevereiro de 1998, Ariranha-SP, em 21 de março de 1998 e Embaúba-SP, em 3 de abril de 1998.

Na primeira vez, o Circo Real foi encontrado ao acaso, durante viagem até Pirangi-SP. A equipe de pesquisa parou, fez contato e esperou pela matinê, que acabou não acontecendo, por causa das fortes chuvas na cidade. Contudo, fez entrevista com o palhaço Bochechinha. Nas outras oportunidades, os espetáculos contaram também com a participação do palhaço Piquito.

O Circo Real era pequeno, com uma lona bastante surrada e com poucos recursos técnicos de som e luz. Ele tinha um espetáculo voltado para o circo-teatro, com variação diária de repertório, porém, 


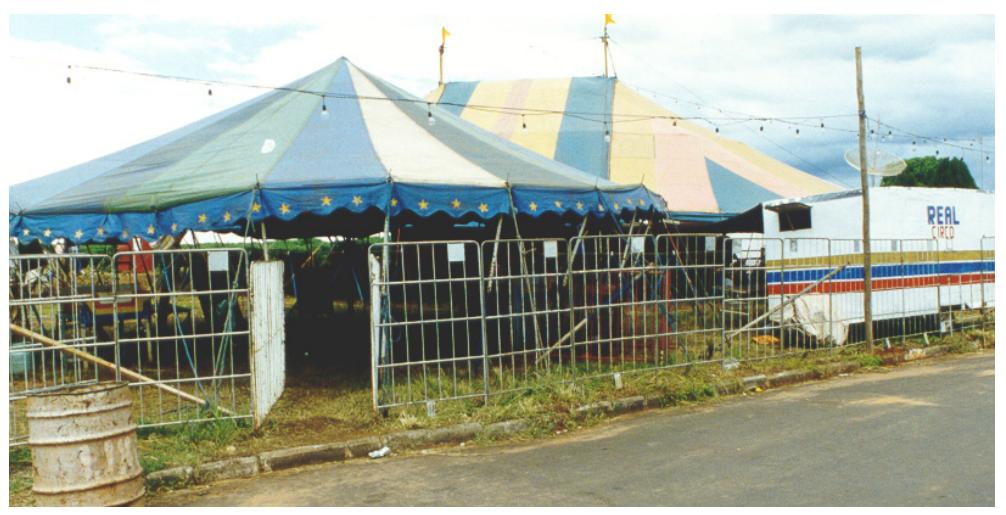

com predomínio de comédias. Eram poucos os números circenses. Neste circo e neste tipo de espetáculo, o palhaço tem um papel de primeira grandeza e, antes de tudo, deve ser um exímio ator. Todos os momentos do espetáculo requerem uma performance convincente do palhaço. O público vai ao circo, exclusivamente, para vê-lo.

O Circo Real foi um bom exemplo da versatilidade dos pequenos circos e do papel de destaque de seus palhaços. Em Ariranha, o espetáculo foi totalmente montado em função deles. A primeira parte contou com Bochechinha, que se aproveitou do circo lotado e teve a oportunidade de demonstrar toda a sua capacidade para a improvisação. Depois, ocorreu um show musical, com músicos da própria companhia, destacando-se as paródias cantadas ao violão por Piquito. Em seguida, foi encenado o drama "O ébrio", que se transformou em uma hilariante comédia. Em Embaúba, o espetáculo, alguns números circenses, com artistas da própria família. Depois, o show musical e, na sequência, a comédia "O macumbeiro", com Piquito.

\section{Bochechinha}

Rodrigo Maciel Camargo, o Bochechinha, em 1998 tinha 19 anos de idade. Ele era da família proprietária do Circo Real e desde crian- 
ça atuava no picadeiro como palhaço. Além de palhaço, Rodrigo era músico e participava do show do circo. Ele fez proveito de seu conhecimento musical em entradas com xilofones improvisados de garrafas. Apresentou-se, também, em número de monociclo.

Sua maquiagem era bastante despojada. O branco estava presente de forma sutil nas duas pálpebras (cortadas por um pequeno risco preto) e no bigode. Este último recebia um contorno preto, que tinha continuidade no lábio inferior, pintado de vermelho, porém sem que a pintura se estendesse para além do limite da boca. O nariz era vermelho. Uma pequena pincelada, também de vermelho, se fazia presente nas bochechas. Alguns pontos pretos realçavam o queixo.

Bochechinha se dedicava a todas as possibilidades artísticas da profissão. Tanto se voltava para reprises, em momentos de paródia de números tradicionais circenses, que frequentemente compõe o repertório das companhias, como para entradas, quando não necessariamente o enredo se volta para temas do próprio circo e que têm no elemento linguístico seu principal apoio, como para esquetes e peças teatrais, especialmente comédias.
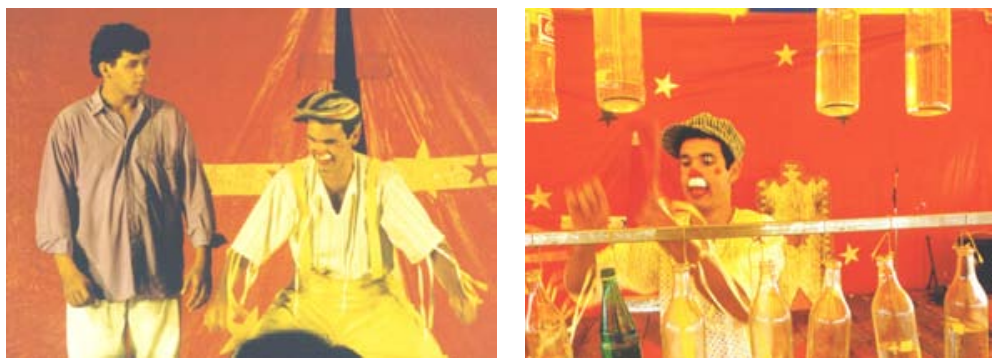

A eficácia de uma entrada, por exemplo, é determinada pela estreita relação que o artista estabelece com o público. Quando há essa ligação, o artista pode perfeitamente propor, durante a representação, a junção de outras entradas. Bochechinha, baseando-se na improvisação e na empatia com a plateia, provocou a junção de duas entradas: "O caçador e o piano".

Bochechinha contou uma história de caçada. Listou vários bichos que caçou e comeu, até que chegou a vez do veado. Então, afir- 


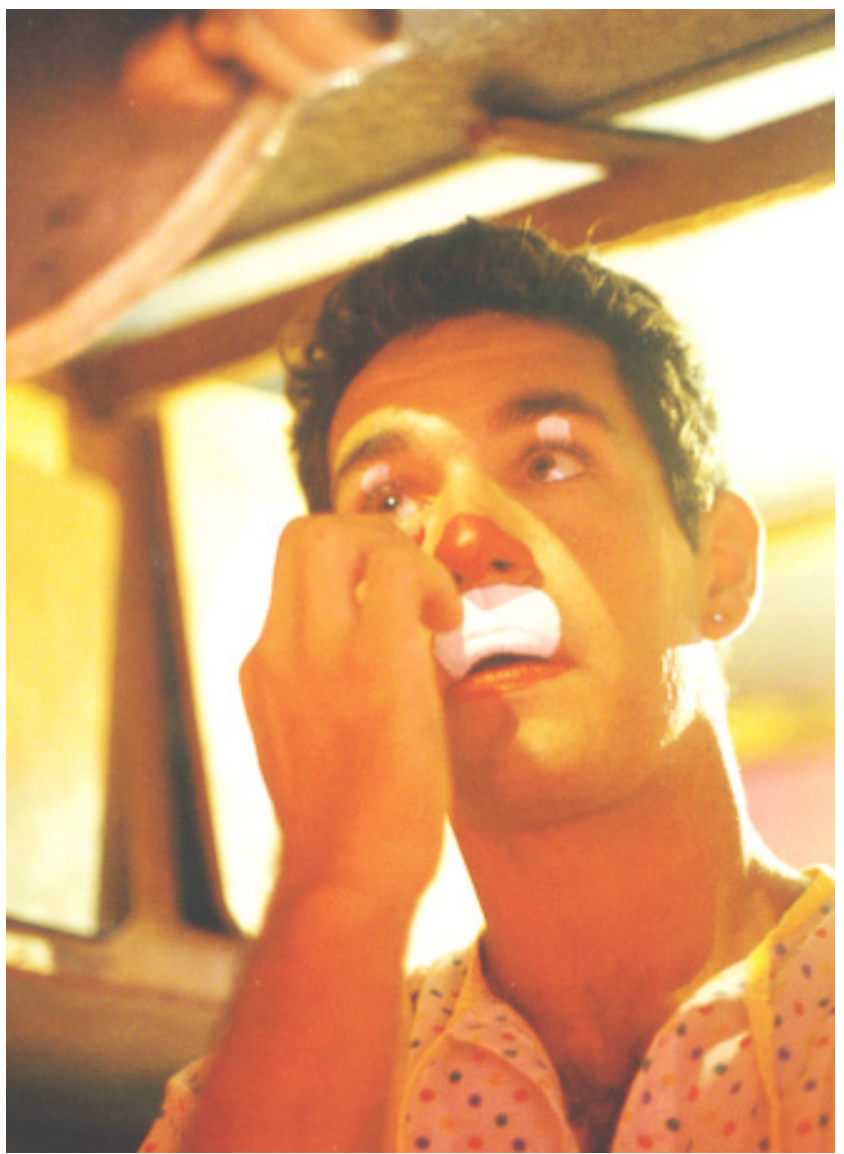

mava categoricamente que não comeu o veado. $\mathrm{O}$ parceiro duvidou. Dizia, entretanto, que nessa caçada aconteceu algo inusitado, que encontrou um bicho estranho, peludo, sem olhos, sem nariz, só boca e vermelho (e fazia gesto associando ao órgão genital feminino). $\mathrm{O}$ parceiro perguntou o que ele fez. Bochechinha disse que correu e quanto mais corria, o bicho estranho e peludo continuava atrás dele... Resolveu se esconder embaixo da saia de uma velha, o que, segundo ele, foi ainda pior, pois enfiou o nariz dentro da boca do bicho cabeludo da velha. O parceiro disse que ele era mentiroso e o chamou para brigar. 
Nesse momento, entrou o Mestre de Pista e tentou apaziguar os ânimos, sem muito sucesso. O Mestre fixou, imaginariamente, um território circular e o palhaço, fazendo gracinhas sobre o tamanho do buraco do parceiro, queria brigar. O Mestre de Pista despediu o parceiro. Bochechinha se intrometeu e perguntou se o Mestre mandou seu parceiro embora. A resposta foi afirmativa e o palhaço agradeceu. Sentindo-se objeto de gozação, o Mestre de Pista se desentendeu com o palhaço. Em solidariedade ao parceiro, Bochechinha resolveu ir embora também. Imediatamente, o Mestre aceitou e despediu os dois. Os dois, despedidos, reclamaram por suas coisas e o único objeto que lhes pertencia - e que lhes foi entregue - era um lençol.

O palhaço e seu parceiro resolveram ter alguma ideia para ganhar dinheiro. Bochechinha queria vender sorvete, mas o parceiro queria uma banda. Os dois resolveram trabalhar como músicos. $\mathrm{O}$ parceiro convenceu o Mestre de Pista: eles eram bons músicos e Bochechinha era um grande pianista. $\mathrm{O}$ palhaço, não entendendo nada do que se passava, apenas confirmou. Ambos estavam contratados novamente. O Mestre pediu para buscarem um piano. Depois de muitas desculpas, eles disseram que tinham seu próprio piano e que iriam buscá-lo. O Mestre de Pista saiu e eles começaram a se desesperar, porque não existia piano, muito menos pianista... $\mathrm{O}$ palhaço entrou em pânico. Contudo, acharam uma solução: o palhaço seria o piano, coberto com o lençol, e o parceiro, o pianista. Combinaram o engodo: quando o parceiro tossisse, o palhaço, coberto pelo lençol, começava a tocar; quando ele batesse o pé no chão, o palhaço pararia. Eles fizeram um ensaio e o palhaço fez tudo errado. Resolveram, então, inverter os papéis, porém mantendo a combinação para iniciar e terminar a música. Bochechinha chamou o Mestre de Pista e mostrou-lhe o piano. O Mestre pediu duas músicas. Obedecendo ao combinado, o parceiro, agora na função de piano, tocou com um apito de sorveteiro, enquanto o palhaço fazia das suas: tocou com o pé, com as nádegas, sem as mãos etc. Batia o pé e o outro, embaixo do lençol, parava de tocar. De repente, o Mestre tossiu, por causa das batidas do grande sapato do palhaço, que estavam levantando poeira. O piano começava a tocar sozinho e o pa- 


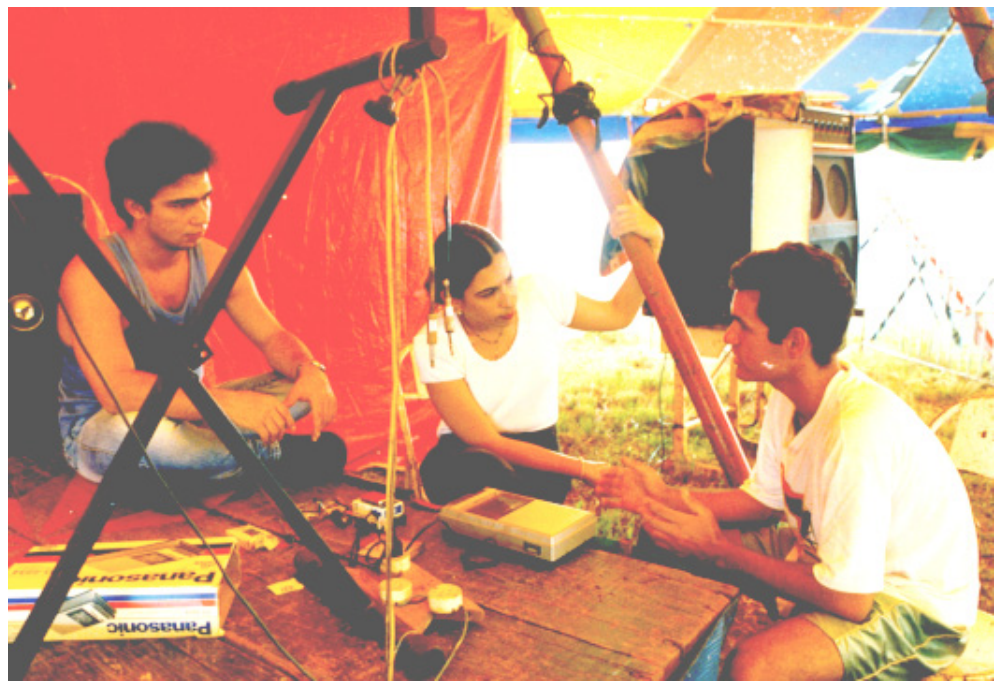

lhaço corria ao piano para cumprir o seu papel. Isso se repetiu por duas vezes, até que o Mestre de Pista descobriu a malandragem. Os dois saíram de cena apanhando.

\section{Entrevista}

Hoje em dia, pra ser um circo grande tem que ter muita potência, muito dinheiro. E o circo pequeno não, você tem o palco, tem as luzes... A maioria dos circos pequenos que tinha teatro tá acabando, uns pararam, outros foram pra circo grande. Por causa disso, agora a gente optou por isso, porque a gente gosta, a gente nunca trabalhou em circo grande, sempre foi isso e a gente acostumou com o teatro. Então, a gente leva o teatro.

O palhaço gosta de trabalhar com o circo cheio, né! igual um jogador de futebol, gosta dos estádio lotado, né! agrada mais, lógico, né! Agrada mais e outra: muitos palhaços não brincam com a plateia e a gente aqui de circo pequeno, o palhaço trabalha mais com o público, ele chama um pra dançar, brinca com o outro da bancada... 
Então, o palhaço de circo pequeno é essa relação, ele faz do público o personagem também, ele chama, trabalha com o povão da cidade.

“Ei, cê é palhaço, rapaz?” E a gente ser de circo também é isso! A gente vai jogar bola aqui, a gente vai no campo: "É palhacinho de circo, né!” Deixa ele pra lá! Tem uns que é assim, mas a maioria não, a maioria vem, pergunta: "Oi, como que é o circo? Como que é isso, tal...", e o palhaço sempre é a atração do circo, pelo menos circo pequeno! Eu gosto de ser palhaço. Mas tem as horas boas e as horas ruins... mas é gostoso sim. A gente tá triste, alguma coisa que aconteceu, a gente tem que entrar do mesmo jeito, e trabalhar, e fazer o povo rir do mesmo jeito, não pode entrar e ficar morto lá. É isso aí, é só alegria...

\section{Piquito}

Osmar dos Santos, o Piquito, nasceu em 1934. Estreou no circoteatro com 5 anos de idade. Até os 15, trabalhou também como trapezista. Quando seu pai resolveu montar seu circo próprio e precisando de um palhaço, resolveu dar oportunidade ao filho e provocar o nascimento do palhaço Piquito, nome que se originou do apelido que o menino tinha desde criança. Além de palhaço, Osmar dos Santos também é autor de dramas e comédias.

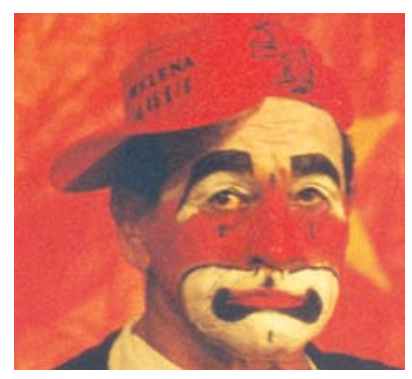

Piquito era bastante hábil na mímica, nas expressões vocal, facial e corporal. Atuava em entradas, reprises, como humorista, cantava 


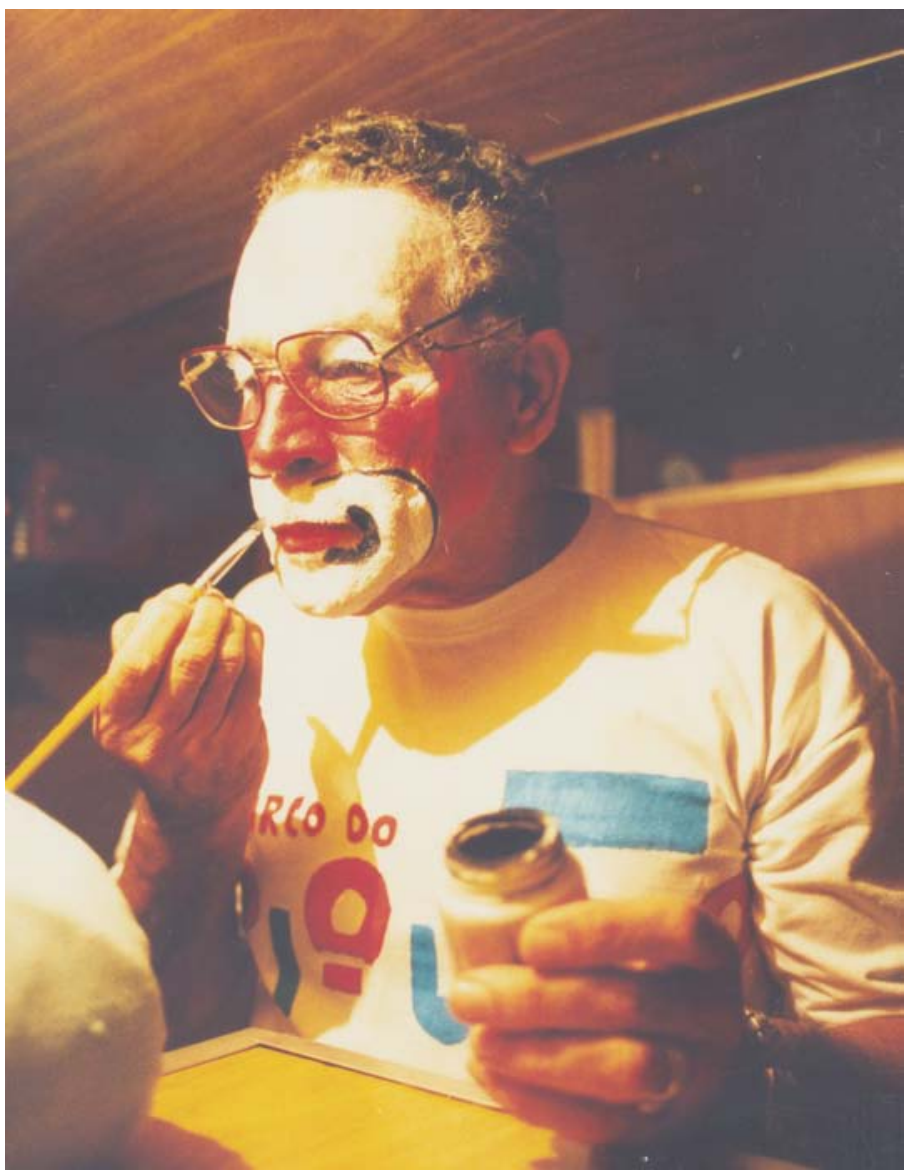

paródias, contava piadas, mas não escondia sua predileção pelos papéis cômicos das comédias e dramas.

Ele foi visitado no Circo Real em duas oportunidades, nas cidades de Ariranha, quando encenou "O ébrio", e Embaúba, com a comédia "O macumbeiro". Em ambas as cidades ele participou do show musical, tocando violão e interpretando paródias. Piquito foi descrito e analisado minuciosamente no Capítulo 5, O Corpo faz a diferença, do livro Palhaços (São Paulo: Editora Unesp, 2003, p.103-162). 


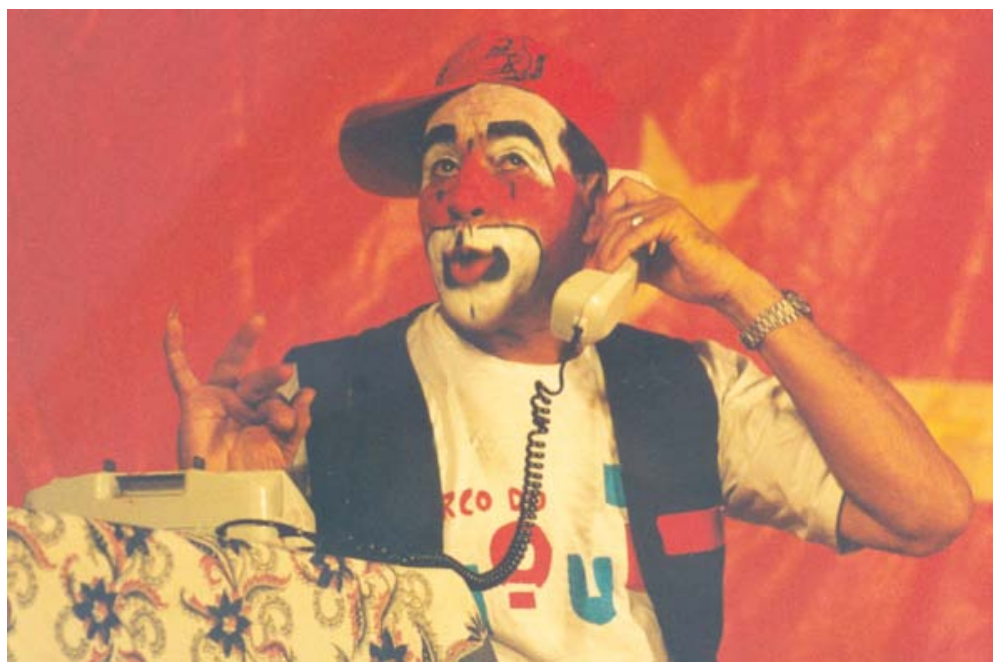

\section{Entrevista}

Eu me dediquei mais ao circo-teatro. Existiam três classes de circo: o circo de primeira classe, a gente falava circo de tiro. Circo de tiro, por quê? Porque chegava o circo com bicho, com toda aquela coisa, propaganda e tal, e dava o tiro! Pegava a estreia, no segundo espetáculo era o mesmo (como até hoje). O povo ia por que pensava que ia assistir outra coisa. Então, dava aqueles três espetáculos, ou quatro, e se a praça não é muito boa, ia embora senão...

A outra, era o circo de teatro. Ele tinha também a variedade no picadeiro. Era o circo de segunda parte, que a gente falava. Por que segunda parte? Segunda parte era o teatro. Primeira parte era o picadeiro, segunda parte era o teatro. Naquele tempo não tinha show. E, depois, passou a ser três partes: picadeiro, o show e, depois, a peça.

A terceira era o mambembe. Não tinha palco: ele apresentava os dramas no picadeiro. As pecinhas que passava eram no picadeiro, comédia, essa coisa e tal. Não tinha ponto. Eles levavam tudo decorado.

Eu trabalhei mesmo, mesmo, na segunda. Trabalhei também nessa primeira e no mambembe... pequeno, meu pai, minha mãe... 
Depois, a gente passou pra outra, porque naquele tempo tinha muito artista e pouco circo. Então, pra gente conseguir um emprego num circo de segunda, era difícil, porque tinha muito artista, e artistas bons, de segunda parte, dos dramas, artistas de dramas, com o guarda-roupa deles mesmo, assim, guarda-roupa normal, não o guardaroupa de... vamos dizer, assim, uma peça Luís XV, como a Tosca, como os Irmãos Corsos.

É muito difícil, o palhaço no circo. Por quê? Geralmente o sujeito que vai fazer o palhaço... a primeira vez que ele vai fazer ele lembra de um outro palhaço que fez aquilo, uma certa parte cômica que faz lá, entrada cômica - que a gente fala - então, ele faz uma que ele lembra, a primeira noite. A segunda noite ele lembra de outra, e faz aquilo que ele viu fazer. A terceira noite ele lembra de outra e faz aquilo ali. A quarta noite ele já lembra de alguma bem ruinzinha. Geralmente, então, na quarta ou quinta noite, ele já toma vaia:

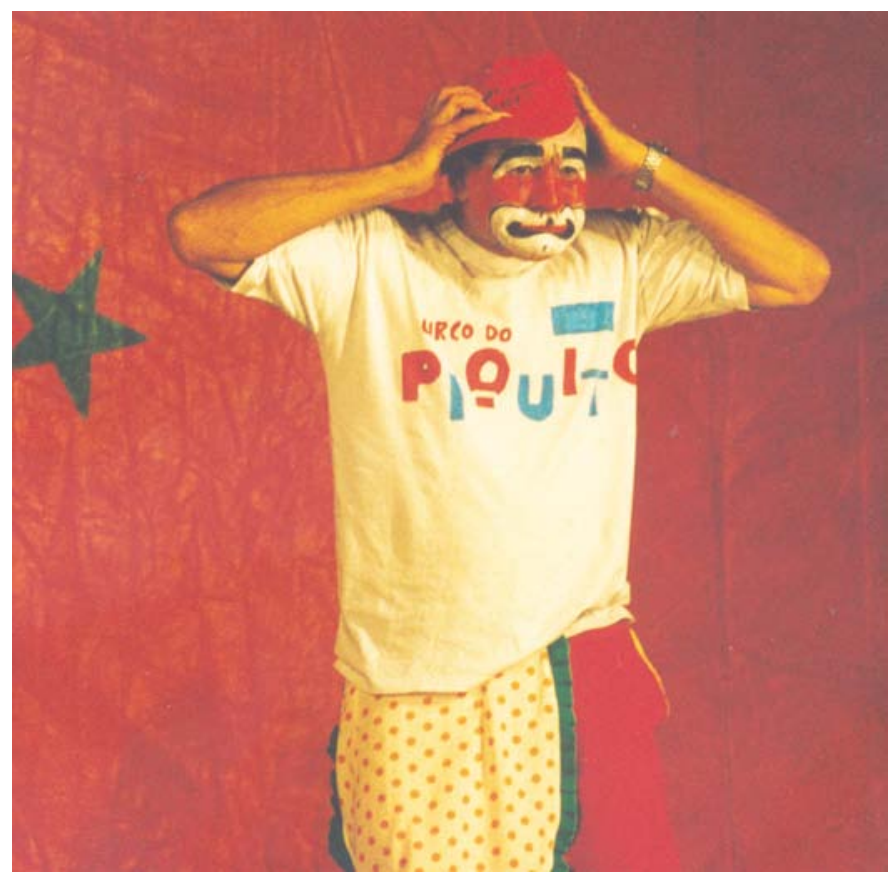



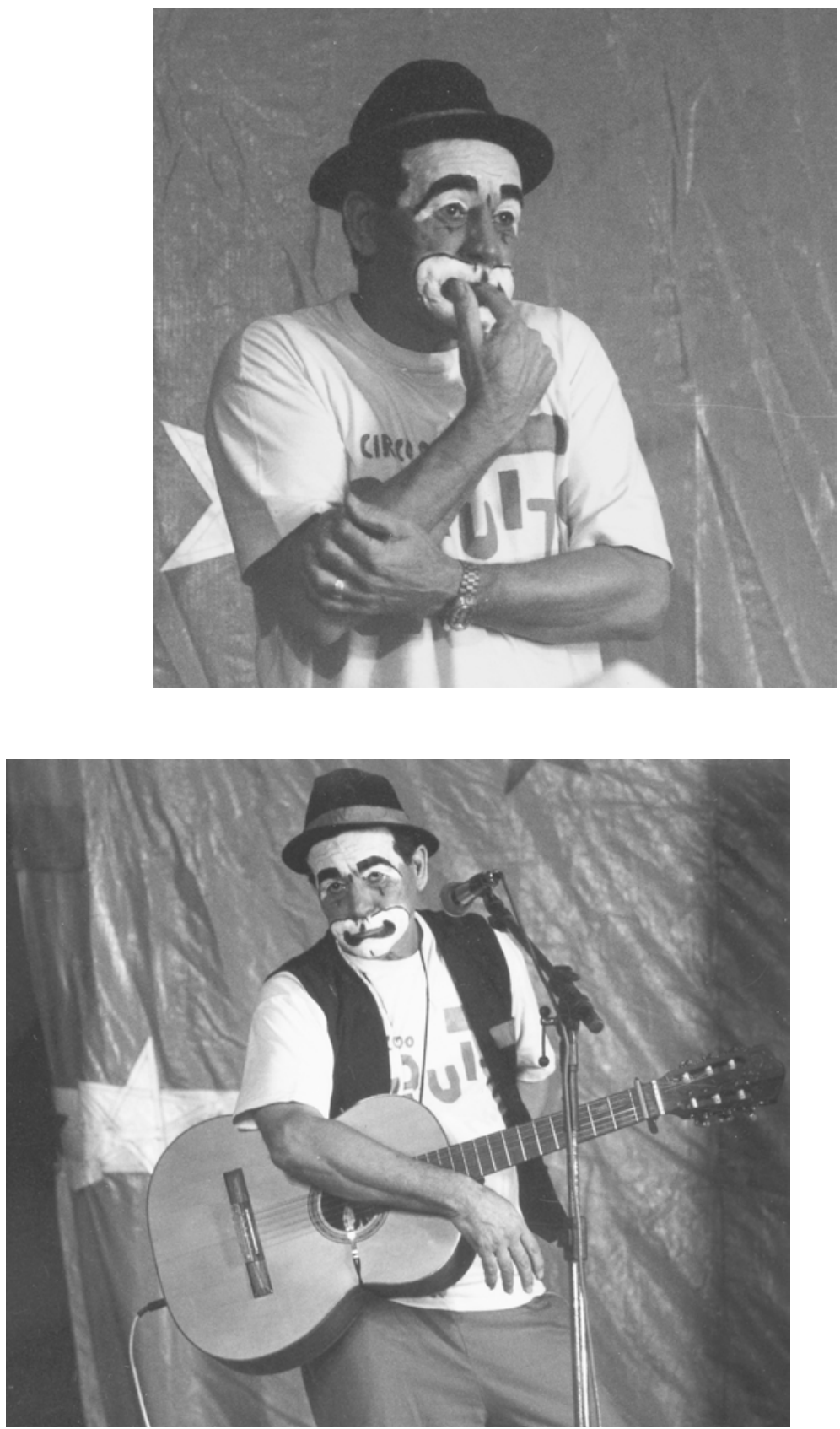
"palhaço ruim". Eu prefiro mil vezes uma plateia de teatro do que uma plateia de circo, porque o circo não perdoa.

A boca contornada maior, ela dá mais condição de você fazer uma careta e ela obedecer. Conforme mexe com a boca ela abre, ela fecha, ela vai... essa foi uma das coisas que eu descobri fazendo palhaço.

A música fez sucesso eu faço a paródia dela. Tenho facilidade pra isso. Mesmo sem estar no circo eu faço elas.

Eu adoro duplo sentido. Justamente por isso eu gosto da plateia do teatro: plateia fina, é bom trabalhar. Mas, tudo bem... eu consegui um nível que atinge os dois, atinge a alta e atinge a média e atinge a baixa também! Inclusive até criança também entende...

Não, eu acho que isso é um recurso muito baixo. Inclusive na comédia de ontem, no fim da comédia, aquele que faz aquela bichinha, ele fazendo gesto feio, eu falei pra ele: "Não faz mais aquilo ali não, aquilo ali não tem graça, pejorativo, não fica bom aquilo ali... não precisa disso".

Ele falou pra mim: "Escuta Piquito, me conta qual é o segredo da arte de fazer rir, qual é o segredo do domínio da plateia?”. Eu falei pra ele: "Olha professor, você tá me perguntando pra te ensinar uma coisa, em 5 minutos, que eu levei 40 anos pra aprender!" É a própria convivência com a plateia, e com as piadas que dão esse motivo pra gente, que dão essa condição... isso vai tempo, pra ele ter essa certeza de parar e esperar o povo, na pura mímica, o gesto facial. 


\section{4 \\ Circo Brother's}

\section{O espetáculo}

Primeira parte: Trapézio em Balanço, Fogo; Chupetinha e Pintinho em "O ladrão"; Quadrante; Chupetinha e Pintinho em "O banco pegou fogo"; Chicote; Magia.

Segunda parte: Comédia “À sombra do papai”; Globo da Morte.

O Circo Brother's foi visitado em 12 de dezembro de 1997, na cidade de Uchôa-SP. A lona era de estrutura média, em torno de 30 metros x 40 metros. Em seu interior, o espaço de cena era composto por um palco de aproximadamente 8 metros de boca, por 6 metros de profundidade. Uma cortina vermelha, com estrelas brancas, servia de divisor entre os bastidores e a cena. O público acomodava-se em arquibancadas e algumas poucas cadeiras, separadas por uma pequena cerca. Do lado esquerdo do palco, ao final das arquibancadas, a companhia tinha instalado um Globo da Morte. A companhia não possuía recursos avançados de luz e som.

O espetáculo era voltado para a encenação de comédias, em sua segunda parte. Na primeira, houve alguns números circenses, momento em que os artistas demonstraram suas perícias e habilidades. Eles tinham um razoável domínio técnico dos seus aparelhos. Con- 


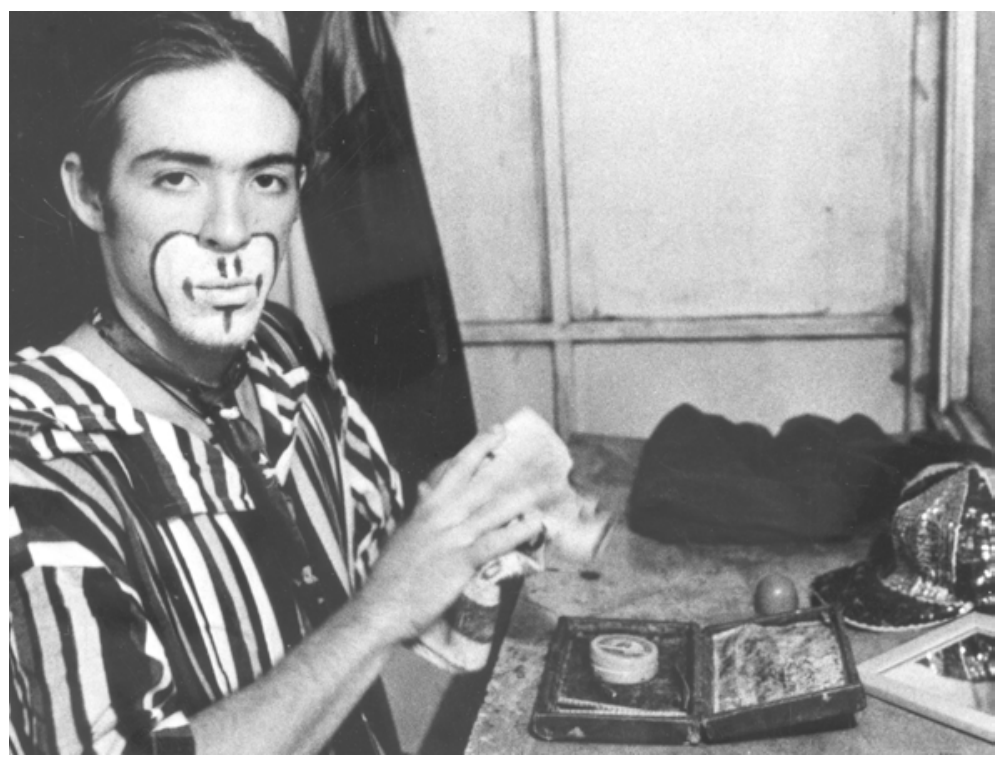

tudo, notava-se um descompasso entre a agilidade técnico-corporal, as coreografias e seus respectivos figurinos.

Os palhaços Chupetinha e Pintinho apresentaram duas entradas, "O banco pegou fogo" e "O ladrão". Chupetinha participou da comédia "À sombra do papai”.

\section{Pintinho}

Pintinho era William Ayres, irmão de Sérgio. Ele tinha 17 anos de idade, em 1997, e assumiu a função de palhaço em 1995. Era parceiro do irmão, na primeira parte do espetáculo, como escada ou "crom".

No espetáculo visto em Uchôa, Pintinho (na foto ao lado) participou da comédia "À sombra do papai”. O cenário era dos mais simples: Uma mesa, coberta por uma toalha, e duas cadeiras.

Sua roupa era composta de uma camisa vermelha, adornada de muitas margaridas e uma grande gola branca. A calça, igualmente colorida, era suportada por suspensórios e alcançava o meio da canela. 
A maquiagem reforçava, de branco, um bigode, contornado de preto. William salientava a parte debaixo da boca com um detalhe branco, também contornado de preto. Três pintas negras realçavam as bochechas. Tal como o irmão, as pálpebras eram cobertas com tinta branca e o nariz era igualmente vermelho, porém o adorno era feito com maquiagem.

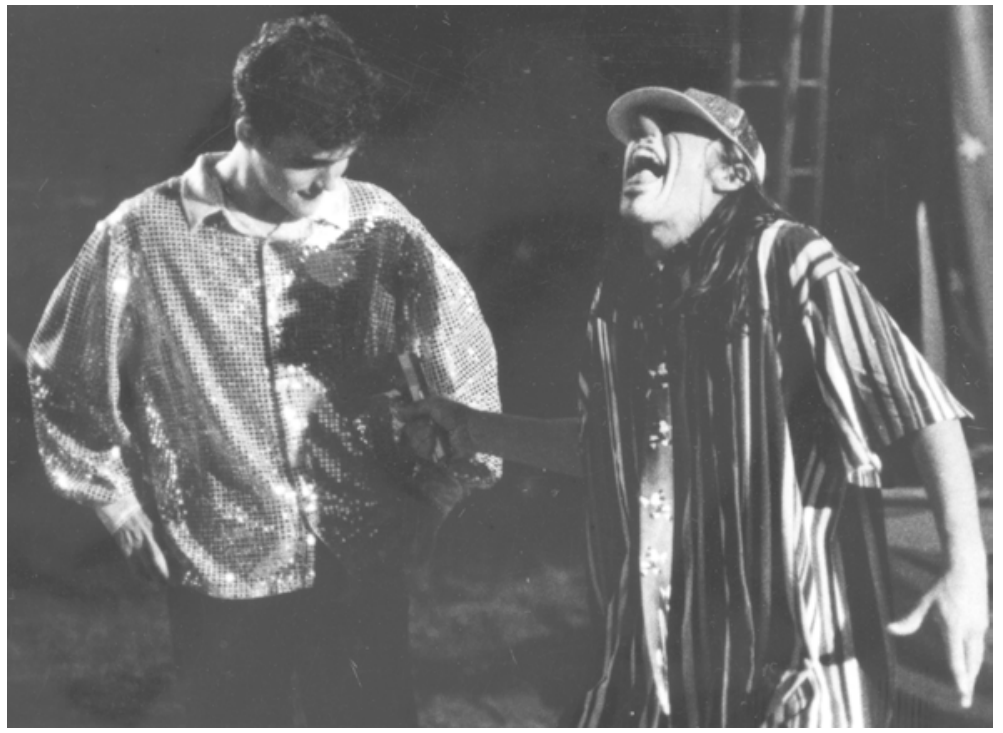

\section{Chupetinha}

Chupetinha foi interpretado por Sérgio Ayres, que contava com 24 anos de idade na época. Ele nasceu e sempre trabalhou em circo. Aos 4 anos ele começou a se apresentar como palhaço no Circo Brother's, de sua família. Além de palhaço, trabalhou também no Globo da Morte e em número de Trapézio em Balanço.

Sua vestimenta era bastante colorida, composta de uma grande camisola listrada que cobria as calças mais justas. Uma grande gravata, com detalhes do Mickey Mouse, e um boné coberto de lantejoulas completavam o figurino. 
A maquiagem reforçava e ampliava a boca, na cor branca, com contornos pretos. Dois traços pretos verticais ligavam a parte superior da boca ao nariz vermelho e artificial. Os cantos da boca eram realçados com traços pretos, ligeiramente curvados. A parte inferior da boca recebia o adorno de outros dois traços vermelhos, um horizontal e outro vertical. As pálpebras apresentavam pequenas marcas brancas.

\section{Entrevista}

Pintinho: Cada palhaço tem seu estilo, né? O dele é redondo, põe nariz... porque não pode ter dois tipos de maquiagens iguais, porque cada palhaço é um estilo. O palhaço se pinta diferente, a roupa é diferente, a voz é diferente, o jeito de falar muda.

Chupetinha: Meu pai fazia assim. Eu aprendi desta forma e gostei. Tem outro tipo também, que o meu tio Pimentão, bom palhaço, fazia. Ele pegava óxido de zinco, vaselina, misturava e fazia o branco. Pegava o xadrez misturava com vaselina e fazia o preto. E esse tipo

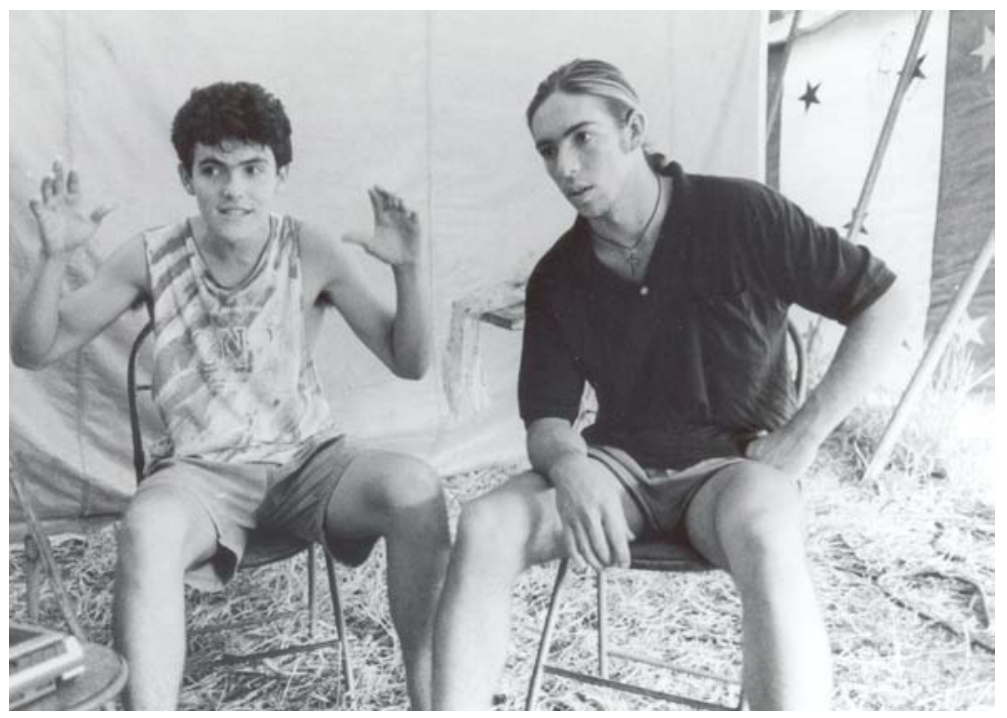




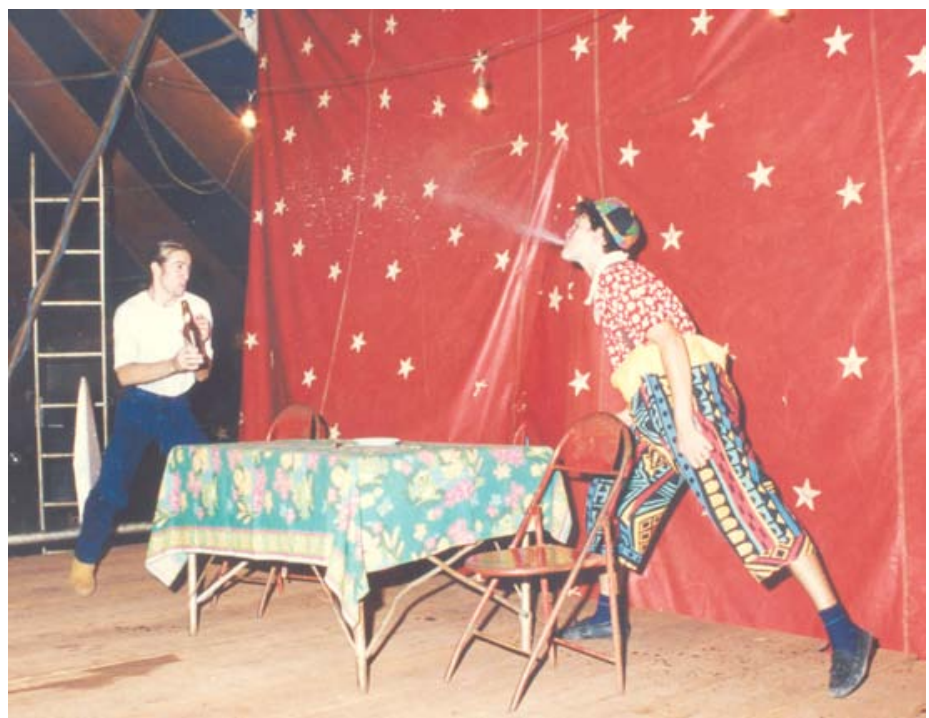

demora mais pra sair da pele. Porque do jeito que eu fico é só tirar meu bonezinho, passar um pano e pronto. É mais fácil a minâncora.

O palhaço tem que conversar com o público, animar o povo. Cada cidade é um povo diferente, tem um povo mais quieto, que é o povo mais difícil do palhaço agradar, e tem o povo mais alegre. Até em Marília mesmo - a gente percebe, porque tá desde pequeno trabalhando - lá na Vila Jardim Califórnia, o pessoal é mais alegre... qualquer coisa que o palhaço falava eles riam. Depois, mudamos para Nova Marília, o povo era mais quieto. Quando é a juventude, eles riem bastante. Quando fomos no Palmital [bairro de Marília-SP] era muita juventude, eles riam bastante. E o palhaço ali no picadeiro tem que fazer o povo rir sem ficar nervoso, tem que se soltar, tem que ser natural. $O$ palhaço, por incrível que pareça, não pode fazer uma gracinha a mais, não adianta ficar uma coisa enjoativa. A pior profissão que tem no circo é o palhaço, não é qualquer um que faz. Você coloca um cara no globo e daqui a dois meses ele faz de bicicleta, e mais dois meses ele tá fazendo de moto. Agora, se coloca um cara pra fazer palhaço não adianta, é um dom que nasce com a pessoa, entendeu? Não é qualquer um. Assim, na atualidade, o melhor 
palhaço brasileiro não tá aqui, tá na Bahia, é o Xupetin, ele tá trabalhando com o Circo Popular Brasileiro... até me arrepia em falar nele: aquele cara é fantástico, é argentino. O cara é fantástico. Eu, que sou palhaço, rio dele. Um palhaço não ri do outro - é muito difícil. Mas eu sou palhaço e rio dele, mais pelo que ele faz, a mímica dele é diferente. Quando estou com uma dor de cabeça, se entra no picadeiro parece que passa a dor, se transforma ali dentro, é outra pessoa, você esquece de tudo. Lá tem que ser alegre, conversar, fazer dar risada. Você pode estar triste, ruim pra caramba... Tem que entrar e brincar com o povo, ser um palhaço.

Já faço isso há muito tempo, e não é automático. Entro no palco já é outra pessoa. Quando veio uma professora, ela tava aqui no fundo do circo, e o palhaço brincando. Quando deu uma explosão ele saiu, ela falou: "Eu percebi como mudou a expressão da pessoa. $\mathrm{O}$ palhaço estava brincando. Quando veio pra cá ele mudou”. É uma química: quando você sobe no picadeiro os problemas somem.

O palhaço é uma profissão bonita, só que tem uma coisa. O circo tá acabando. A minha maior tristeza é ver que o circo tá acabando. O circo não tem apoio do governo. Não é só o circo, no Brasil, a cultura não tem apoio. $\mathrm{O}$ povo não quer mais saber de teatro. Isso me arrepia, eu falo e me arrepio. $\mathrm{O}$ povo não quer mais saber de teatro de circo? A juventude, a cabeça deles não evoluiu com o tempo. Vinte por cento da juventude só pensa em droga. O que passa na televisão é violência, filme de violência, um dando tiro no outro. O circo é o palhaço, um negócio bonito, isso tá acabando, isso é minha maior tristeza. A gente vê em outros países, nos Estados Unidos, na Europa, eles têm apoio. Lá na Rússia, lá o circo Moscou eles dão o maior apoio para os artistas. Lá ganha do governo um salário todo mês, e eu não trabalho por dinheiro, trabalho por amor, que minha família tem mais de 120 anos de tradição de circo. Agora, você imagina, a gente não é bem de vida, a gente está trabalhando aqui, suando, a gente ama isso aqui desde criança, trabalhando. Agora se a gente tivesse uma condição financeira melhor, a gente poderia aumentar isso, podia comprar mais coisas. Um circo maior, contratar mais artistas para trabalhar. E cada vez que passa, o circo está pior. Meu pai 
já parou três vezes o circo. Ele fica uns cinco meses parado e não aguenta, já começa a dor, agonia, saudade do circo. A gente tá acostumado e é nômade. Meus parentes estão parando todos. O Rogério já parou. O Nei tá querendo parar, não tá mais aguentando. É o que eu falei, não é o problema do dinheiro, é que não tem apoio. 



\section{$\stackrel{5}{5}$ SUPER CIRCO BIRA}

\section{O espetáculo}

Primeira parte: Malabares; Birinha em "Salto mortal com a lata na mão"; Corda marinha; Show pirotécnico; Contorção; Clowns musicais; Equilibrismo; Trapézio em Balanço; Cama elástica. Segunda parte: Magia; Clowns musicais; Arame alto; Birinha em "Equilíbrio de ovos"; Trapézio Voador.

O Super Circo Bira foi visitado duas vezes. A primeira, em 23 de janeiro de 1998, na cidade de Bauru-SP; depois, o circo foi encontrado na cidade de Ituiutaba-MG, em 9 de junho de 2000. Nas duas oportunidades, o mesmo espetáculo foi apresentado.

O Super Circo Bira era de estrutura média, com lona vermelha e azul, nas dimensões de 30 metros x 40 metros. Ele estava em formação. Bauru foi a cidade de estreia da companhia. Um picadeiro compunha o espaço de apresentação dos artistas. Em Bauru, a plateia ficava acomodada apenas em cadeiras. Já em Ituiutaba, o circo contava com arquibancadas, cadeiras e camarotes. A melhoria das acomodações do público, entretanto, não foi acompanhada por uma ampliação dos recursos técnicos de som e luz. 


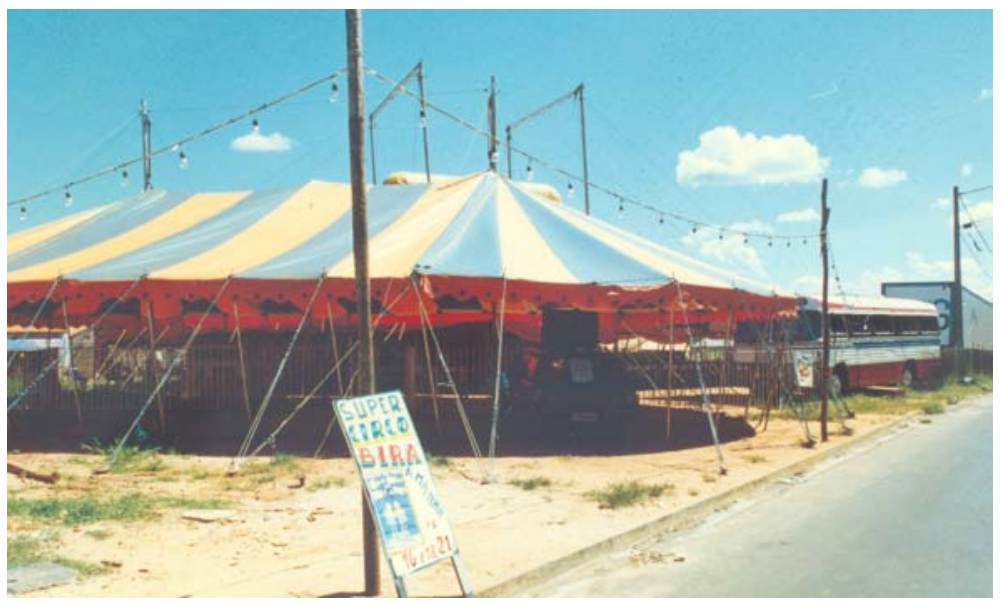

Os espetáculos apresentados foram compostos, exclusivamente, de números circenses. A companhia era a mesma, nas duas oportunidades. Os artistas apresentaram-se com muito afinco. Os números eram bem montados, bastante simples, sem grandes recursos sonoros ou visuais. Os artistas eram bastante empenhados na profissão e isso transpareceu em todo o espetáculo. Apesar de não serem tecnicamente exuberantes, os artistas demonstraram muita vitalidade em cena. Os números foram executados com uma energia reconfortante, característica que faz destoar de muitos espetáculos vistos. Era visível a preocupação da companhia com a transmissão do saber circense às crianças. Alguns números foram executados exclusivamente por elas, acompanhadas de perto pelos ensaiadores.

\section{Birinha}

Raul Gregório Nogueira, nascido em 1969, de família circense, era o proprietário do circo e o palhaço Birinha. Desde criança vinha ganhando a experiência do picadeiro, como palhaço. Seu tipo era alegre e procurava envolver o público em sua apresentação. Assim, estimulava sobremaneira a improvisação. Não apresentava, contudo, 


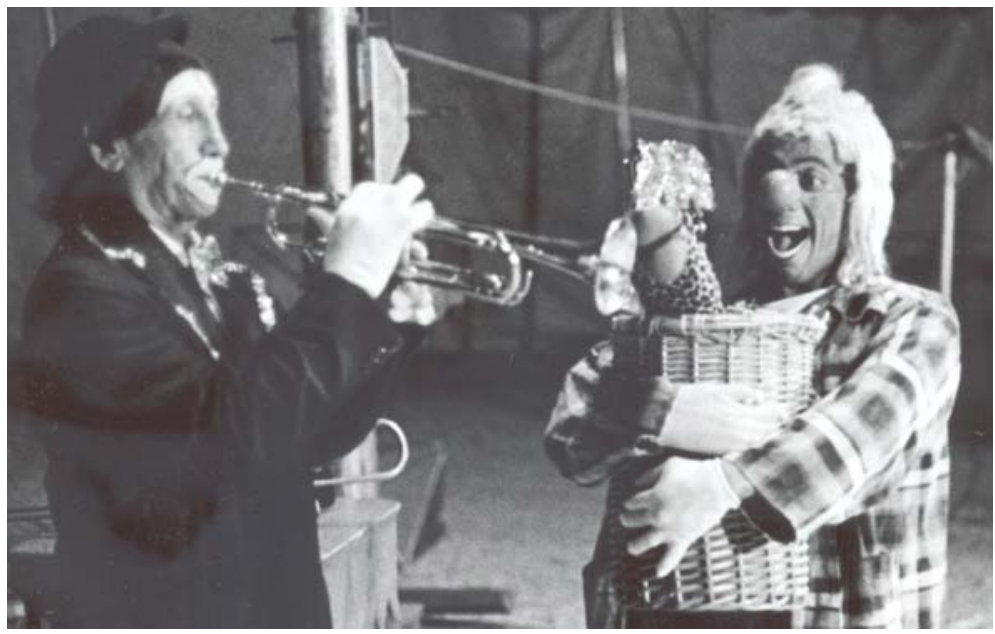

um perfil definido de personagem. Procurava uma caracterização genérica de um palhaço alegre, com uma roupa sem brilho, sem lantejoulas e uma maquiagem que ele mesmo admitiu como sendo a dos "palhaços antigos", ou seja, dos Augustos, composta por branco, vermelho e contornos de lápis preto. O nariz era avermelhado. Um pequeno boné cobria-lhe a cabeça. Uma camiseta de mangas compridas, branca, e um macacão xadrez, nas cores vermelha e preta, completavam seu figurino.

\section{Entrevista}

Eu sou um palhaço mais de entradas, de contar piadas. Mas, pra fazer isso, precisa do quê?? De um clown... Seria um segundo, uma pessoa de cara limpa pra perguntar pra mim, eu responder errado, coisa assim... Como o pessoal que está comigo é novo na área, então não tem como fazer, porque são coisas que precisam ser ensaiadas pra deixar as "deixas" na hora certa, pra você fazer o desfecho da piada.

O público, é o seguinte: você entra sem saber a reação do público. Porque tem público, por exemplo, que participa, você fazendo 
entrada ou reprise, eles participam, eles vaiam, batem palma; já tem aquele público mais frio! Aí, dependendo do público, você vai, vê o que vai levar na hora. Na hora, às vezes você tem que criar e mudar rapidinho. Porque não dá pra estipular: pra esse público eu vou levar isso, porque a gente não sabe a reação deles ali dentro, entendeu?! Esse circo meu, por exemplo, a gente tá tentando resgatar isso; a gente faz todas essas reprises que eu tô te falando, mais mexendo com a criança.

Ensinar, não tem como, porque palhaço não tem jeito de ensinar. O ser palhaço não tem como ensinar: pode ensinar a se vestir, a se pintar, a fazer uma entrada, mas ensinar a ser palhaço não tem como, já nasce com isso.

Agora, acontece de alguém espirrar e você na hora improvisar aquilo, brincar com aquela pessoa, ou um sorriso mais alto que o outro, não é? Uma entrada que você faz e alguém sente um pouco de vergonha, tal. Improviso é isso.

Às vezes, você entra lá sem nada e num sentar, numa palavra, você agrada muito mais que qualquer aparelho. Então, o essencial pro palhaço é dom, e gostar de ser palhaço, né! Isso é o essencial.

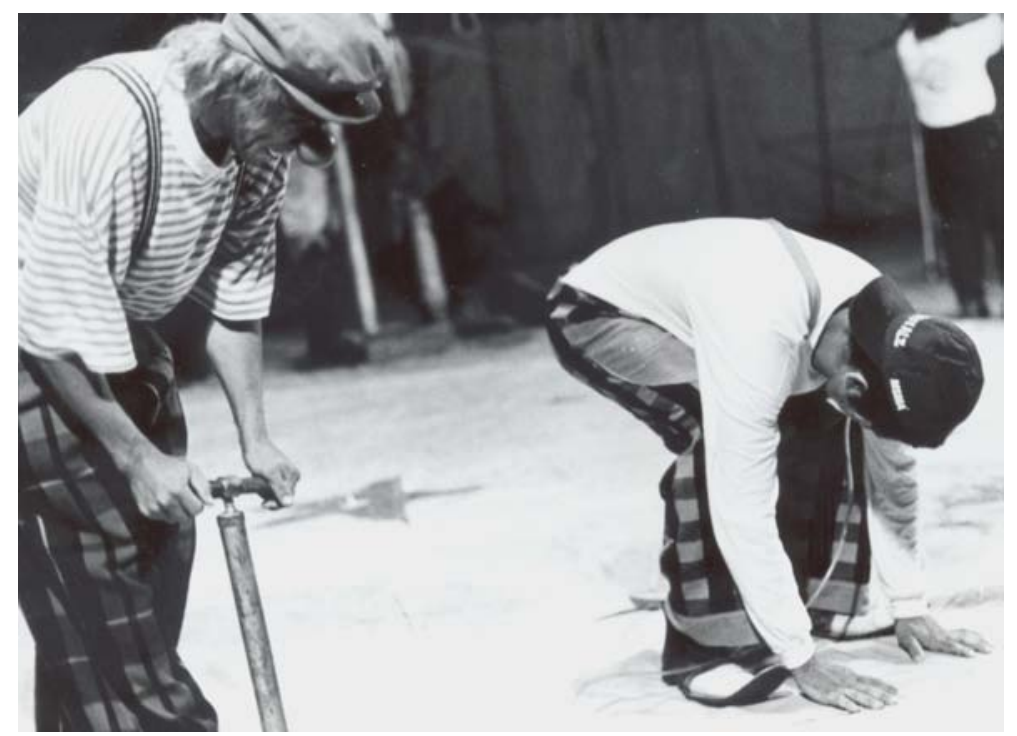


É ótimo, a gente fica contente de ter um trabalho como o de vocês, tentando resgatar um pouco e reviver isso aí... Não que tenha esquecido. Palhaço não vai ser esquecido nunca, não tem televisão, não tem computador, não tem videogame... Palhaço vai ser sempre o palhaço, enquanto tiver criança, vai ter palhaço. 



\section{6 \\ Circo Vostok}

\section{O espetáculo}

Primeira parte: Acrobacia; Força Dental; Acrobacias e paradas; Palhaços; Cães amestrados; Lira.

Segunda parte: Volteio equestre; Palhaços; Leões; Palhaços; Gatos amestrados; Palhaços; Trapézio Voador; Apoteose.

O Circo Vostok, que encerrou suas atividades, foi visitado em Barra Bonita-SP, em 30 de janeiro de 1998. Era um circo grande, com recursos de som e luz suficientes para um espetáculo grandioso. O espaço cênico era composto de um picadeiro de 13 metros. $\mathrm{O}$ público acomodava-se em cadeiras e camarotes. Não havia arquibancadas. As cadeiras ocupavam um plano inclinado, de forma a dar uma boa visibilidade ao espectador.

O espetáculo assistido foi ritmicamente cadenciado, com muita leveza e graça por parte dos artistas acrobatas. Os artistas demonstravam um bom domínio técnico. Alguns deles eram russos, que vieram ao Brasil após a Queda do Muro, em busca de realização profissional. O figurino era bastante trabalhado, com cores vibrantes e muito brilho. 
Em todos os momentos, os palhaços apresentaram-se durante a preparação do picadeiro para outros números, como jaulas para os leões e a montagem do trapézio voador. O repertório constou de reprises tradicionais, como "O caveirão", Telepatia, Boxe e "Salto mortal com a lata na mão". A performance dos palhaços precisava adaptar-se às dimensões do espaço. Nas reprises que contavam com falas, os palhaços entravam com microfones de lapela, o que terminava provocando uma poluição sonora. Isso, por certo, prejudicou o desempenho dos cômicos. Circos grandes exigem do palhaço um repertório apropriado, puramente gestual.

\section{Gori-Gori}

Gori-Gori (na foto, Gori-Gori à direita e Salsicha, à esquerda) foi criado por Fernando Guimarães Brandão. Em 1998, ele tinha 17 anos de idade e trabalhava com seu pai. Além de palhaço, também era trapezista. Porém, noVostok ele não estava desempenhando essa função.

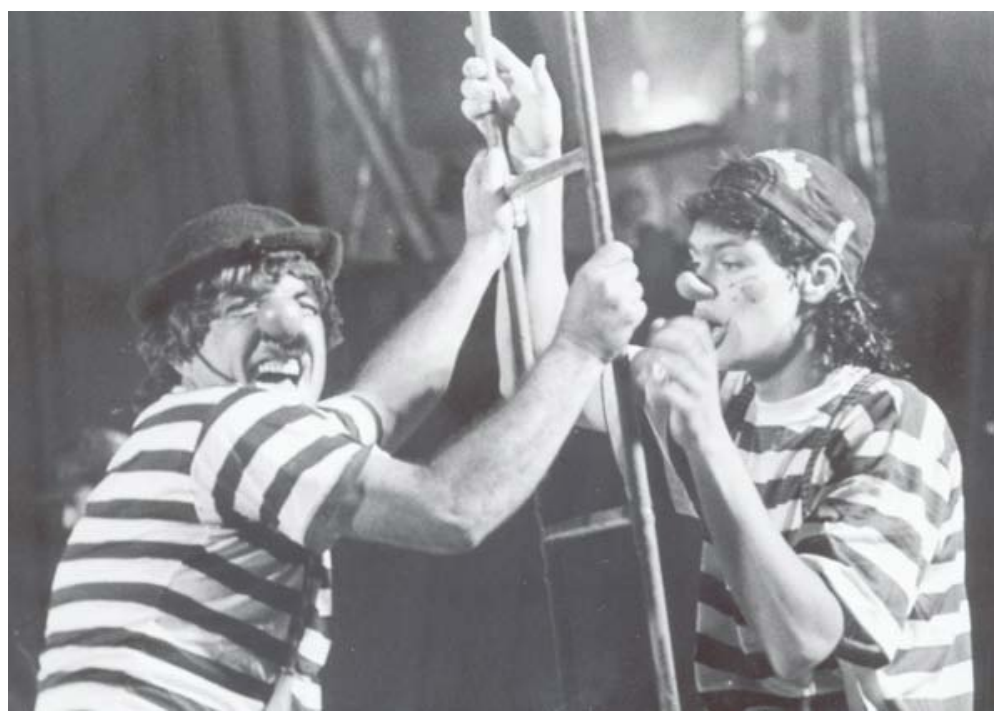



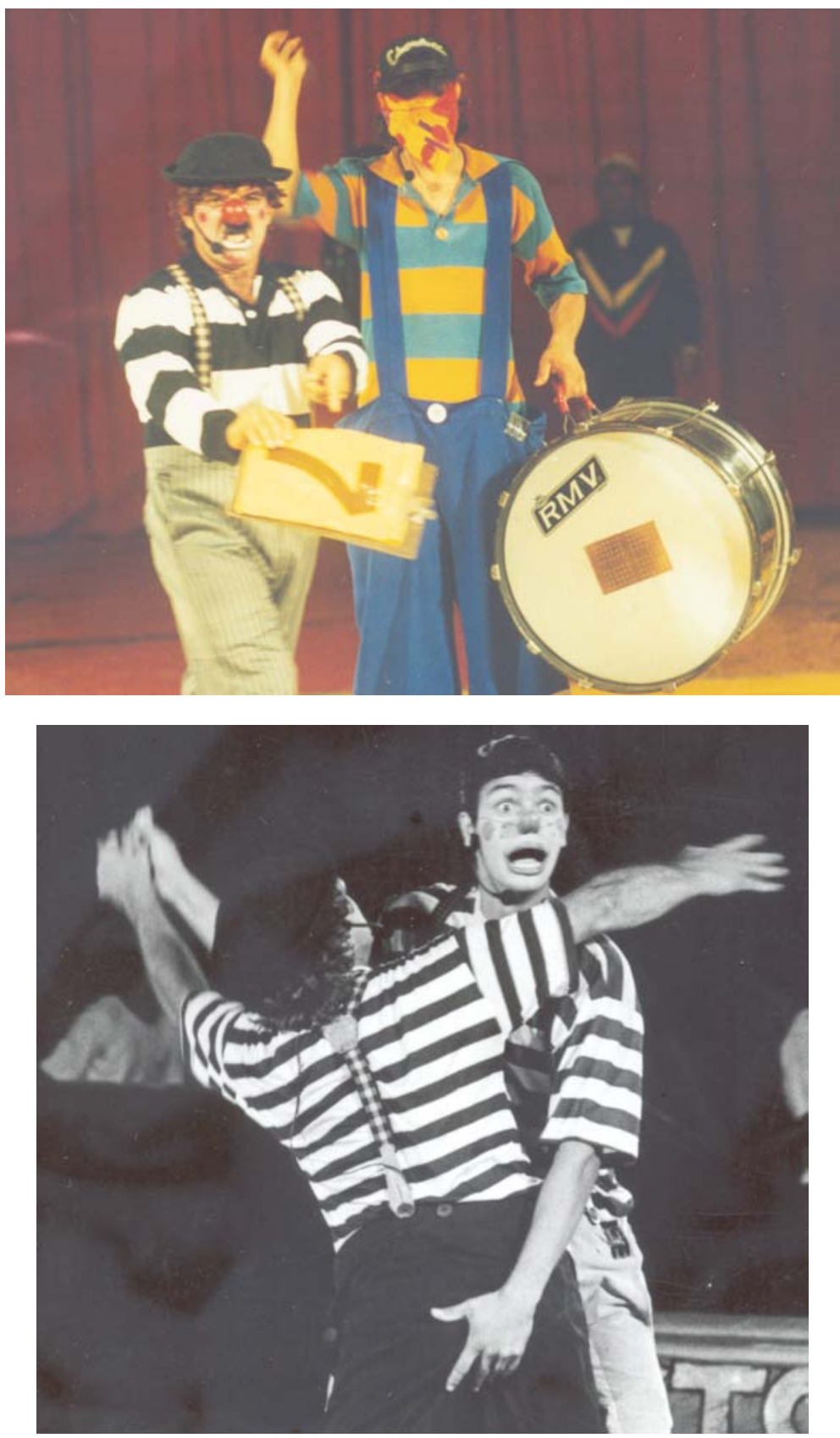
Gori-Gori almejava, como principal característica de sua personagem, ser alegre, agitado e brincalhão. Ele não fazia uso de palavrões ou mesmo de piadas fortes. Ele já trabalhou no Nordeste, em pequenos circos, em bairros e pequenos lugarejos. Segundo ele, lá o público não deixa o palhaço quieto e este termina respondendo com piadas de apelo sexual.

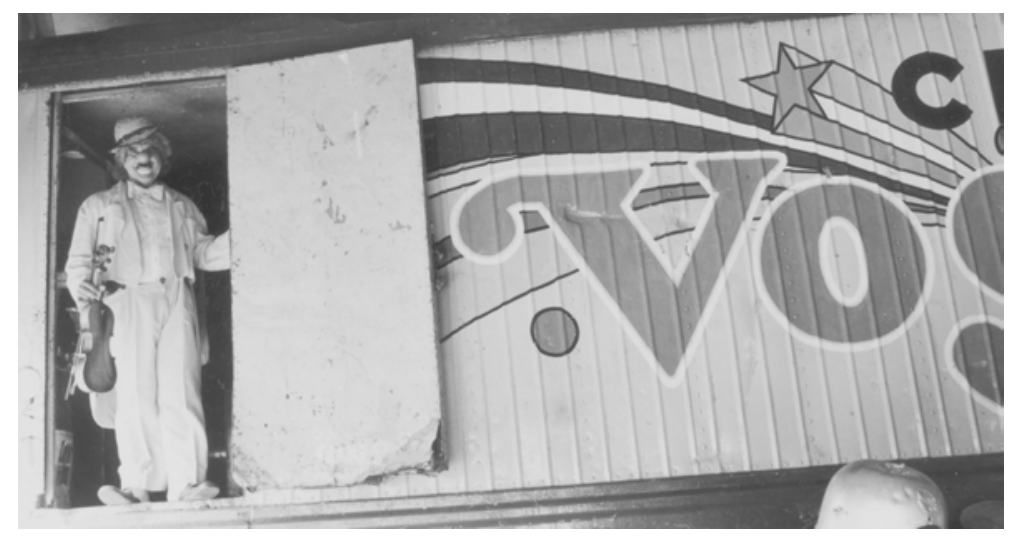

\section{Entrevista}

O circo, hoje em dia, não se valoriza muito. Os russos que vêm pro Brasil trabalham mais barato. Uma dupla de palhaço ganha seiscentos reais, oitocentos reais por semana. E eles não. Trabalham por cem reais por semana. Aí o dono do circo fala: "Por que eu vou pagar seiscentos reais pra um cara se o outro trabalha por cem?”. Aí pega e manda embora. Aí começa a desvalorização do artista. Mas, daí ele vai e compra uma calça que custa oitenta reais. Daí ele pede aumento, que não aguenta. Daí, pede um aumento, aumento, e chega uma hora que eles ganham mais que nós. Daí eles querem contratar nós e pagar uma merreca. "Ah... pra vocês, uma dupla de palhaço, eu pago trezentos reais”. Não, não, assim não dá. Depois, ele começa a se desesperar e procura a gente, porque não tem outro. É muito difícil hoje, um brasileiro, se valorizar. Tem muito palhaço 


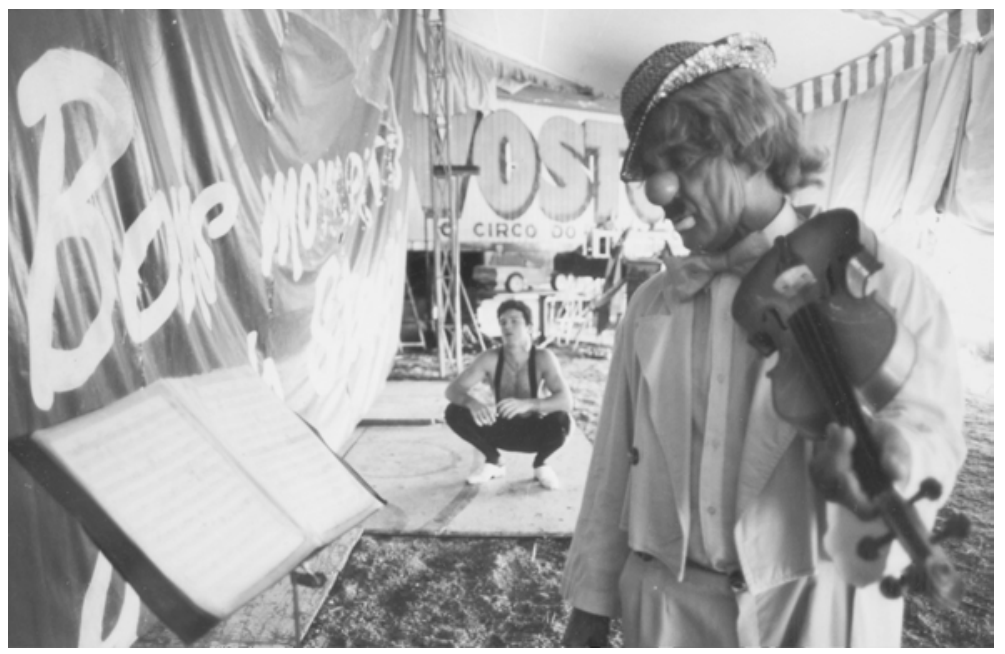

bom, mas tá tudo escondido no circo pequeno. Porque, hoje em dia, é melhor você trabalhá em circo pequeno que em circo grande. No circo pequeno, o povo é mais brincalhão, o dono do circo também. Lá no nordeste, tem circo pequeno, chega um circo grande lindo na cidade, o povo vai no pequeno mas não vai no grande. Porque esse grande quer humilhá o pequeno. Daí o pequeno lota, mas não lota o grande. O povo fala assim: "Pô...eu vou no circo pequeno. O pequeno é mais divertido". Porque o jeito de trabalhar é diferente. No grande, eles não brincam, sempre sério. No pequeno, eles bolem com o povo, brinca. Ai o povo já participa, fala com os palhaços.

Palhaço não é uma profissão ruim. "Ah, palhaço é fácil!”, dizem; “É fácil! Então entra lá!”, eu falo. Daí, ele entra e fica olhando o público: "Que que eu faço? Que eu faço?". Tem que prender a atenção do público. Tem que saber o que você vai falar lá dentro, pra não falar besteira, porque circo grande vai muita pessoa, de elite. Vai pessoa rica, vai família média, e não são zoeiras. Gostam de ri, não de ouvir 'putaria': "Pô, aqueles palhaços são muito pornográficos." É muito difícil ser palhaço.

O povo fala que o circo tá acabando. Pra mim o circo nunca acaba. Pode ser grande, pequeno, feio, pra mim o circo nunca vai aca- 
56 MARIO FERNANDO BOLOGNESI

bar. Circo grande, bonito, de bicho tá fechando porque não tão conseguindo pagar artista. Mas eu não pretendo sair do circo. Um dia, meu pai falou: "Estuda, que o circo vai acabar!". Eu não vou parar com o circo. 


\section{7 \\ Circo Real Argentino}

\section{O espetáculo}

Primeira parte: Apresentador; Passeio Aéreo; Trapézio em Balanço; Paradas e Deslocação; Vareta e Salgadinho em "O jornal”; Bambu; Turbilhão

Segunda parte: Show com os Bananas de Pijamas

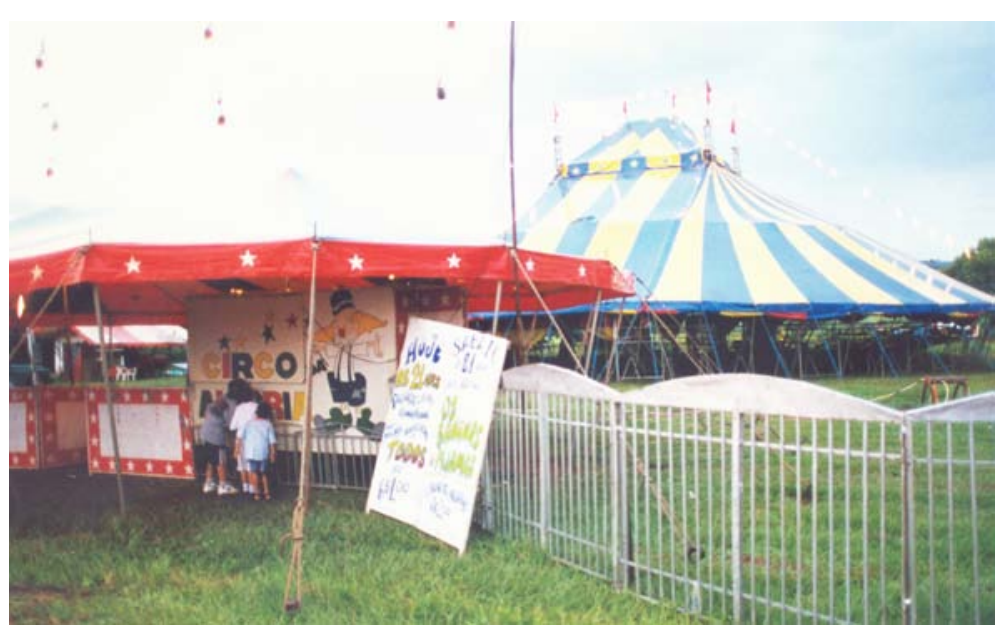


O Circo Real Argentino foi visitado no dia 14 de fevereiro de 1998, na cidade de Pirangi-SP. O Real Argentino era um circo médio, de 30 metros x 40 metros, com quatro mastros e cúpula retangular. Ele era muito bem organizado e com bons recursos sonoros e musicais. O espetáculo, naquele dia, foi bastante reduzido, tendo em vista a apresentação do show dos Bananas de Pijamas, uma prática comum nos circos: apresentações de astros da televisão, na segunda parte do espetáculo. Diante dessa peculiaridade, não se viu nos artistas do circo maior empenho em suas performances. Os palhaços estiveram restritos a uma única entrada, com a função explícita de manter o ritmo do espetáculo. De um modo geral, o espetáculo apresentou um predomínio de números aéreos.

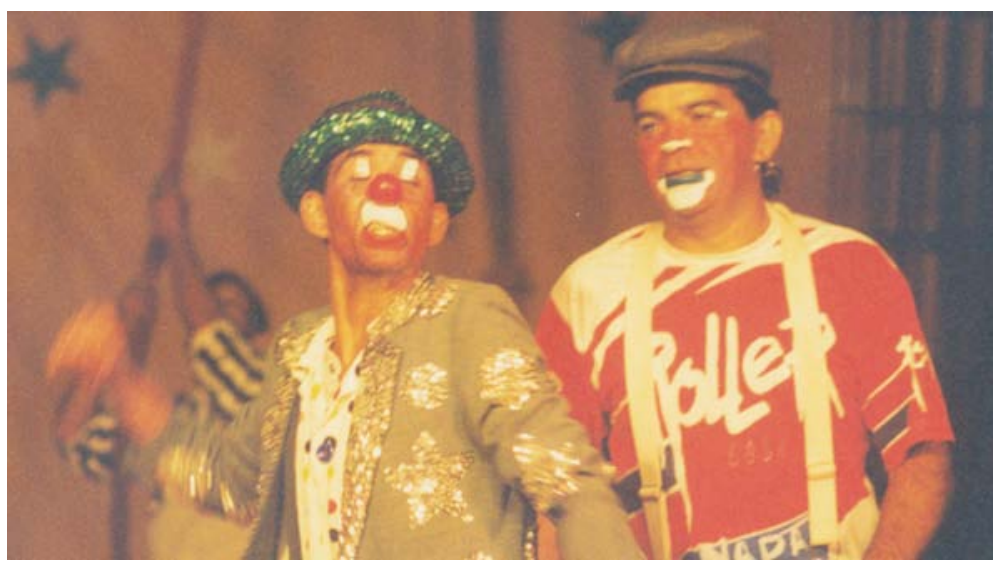

\section{Vareta e Salgadinho}

Os palhaços Vareta e Salgadinho participaram apenas de uma entrada, a do "Jornal", na primeira parte do espetáculo. Como os demais números, tiveram uma performance desmotivada, uma vez que a "estrela" do dia era o show anunciado. 


\section{8 \\ Circo Sandriara}

\section{O espetáculo}

Primeira parte: Facas; Chicote; Magia, Jurubeba e Bochechinha em "O apito"; Malabares.

Segunda parte: Leões; Cavalos; Pôneis; Jurubeba e Bochechinha em "A noiva"; Búfalo.

O Circo Sandriara foi visitado no dia 20 de março de 1998, na cidade de Fernando Prestes-SP. O dia estava chuvoso e havia sérios riscos de o espetáculo, programado para as 21 horas, ser cancelado. Isso não ocorreu. No entanto, foi reduzido o número de pessoas que compareceu ao circo, o que provocou uma apresentação desmotivada.

O Sandriara era um circo de porte médio, com as dimensões de 30 metros x 40 metros, aproximadamente. Um picadeiro circular era o espaço reservado para a apresentação dos artistas. As acomodações do público dividiam-se em arquibancada e algumas poucas cadeiras, separadas por uma cerca. Os recursos técnicos de som e luz eram bastante deficitários. 


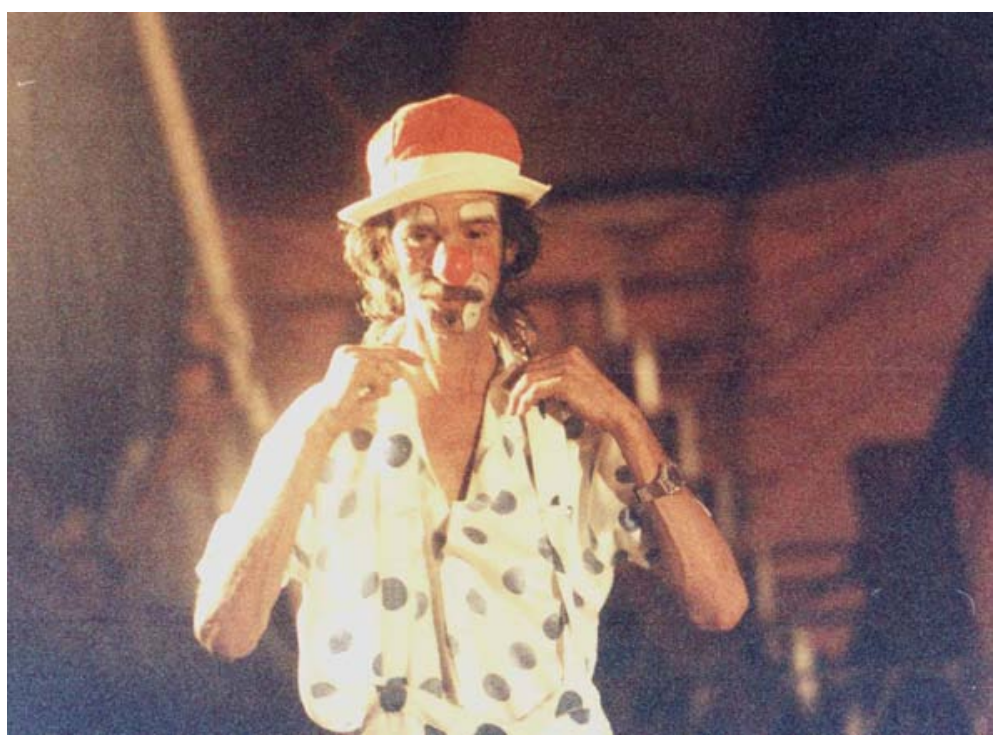

\section{Jurubeba}

Valdir Sampietro, o Jurubeba, nasceu em circo em 1953. Aos 11 anos começou a trabalhar como palhaço. Na profissão, experimentou o ofício em grandes e pequenos circos. Antes de transformar-se em palhaço principal, atuou e aprimorou-se exercendo a função de segundo palhaço, ou "escada" para outros palhaços. Certo dia, o circo em que trabalhava ficou sem o primeiro palhaço. Ele, então, foi escolhido para a substituição. Sempre teve orgulho de sua profissão e admitia que o grande trunfo dessa arte é cultivar um contato estreito com as pessoas da "praça", das cidades por onde o circo passa. Com isso, familiarizava-se com as preferências do público, além de incentivar as pessoas a comparecerem ao circo. Em 14 de setembro de 1998, com a saúde fortemente abalada, Valdir Sampietro morreu, levando consigo o Jurubeba.

Jurubeba, extremamente magro, explorava sua condição corporal e fazia dela motivo de riso. Sua personagem, então, calcava-se 

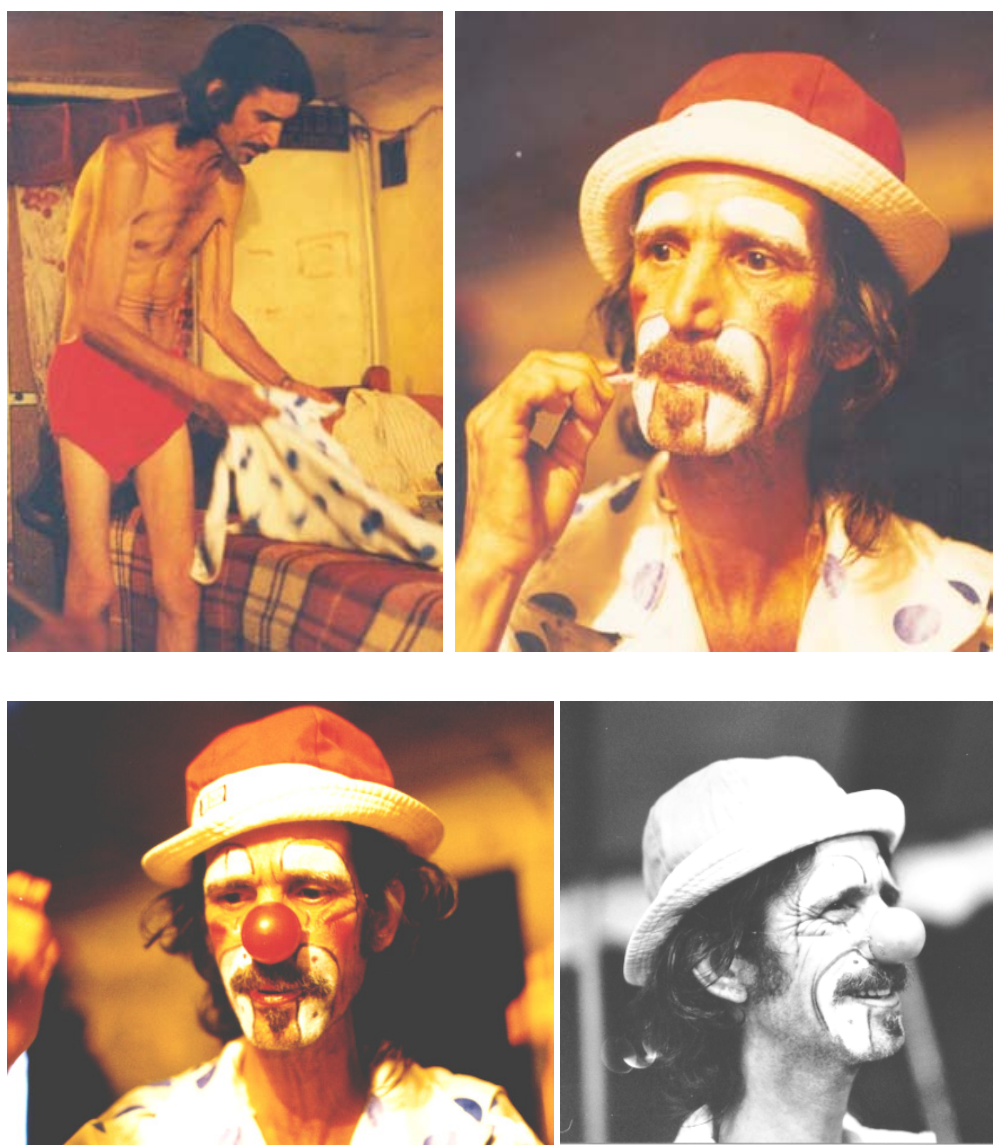

sobre um tipo desconjuntado, quando determinadas partes do corpo apresentam-se em visível descompasso com o todo. Isso era perceptível, por exemplo, na postura das pernas, que não acompanhavam o andar.

Sua personagem formava-se exclusivamente a partir de sua subjetividade, ou melhor, de traços que o dia a dia não permitiam revelar: o desajeitado que, nitidamente, não se adapta às imposições e/ ou convenções da aparência social. A roupa, formada por camisa e uma calça com suspensórios, trazia grandes bolas azuis sobre um fundo branco. Ela contrastava com o corpo esquelético. Assim, quan- 


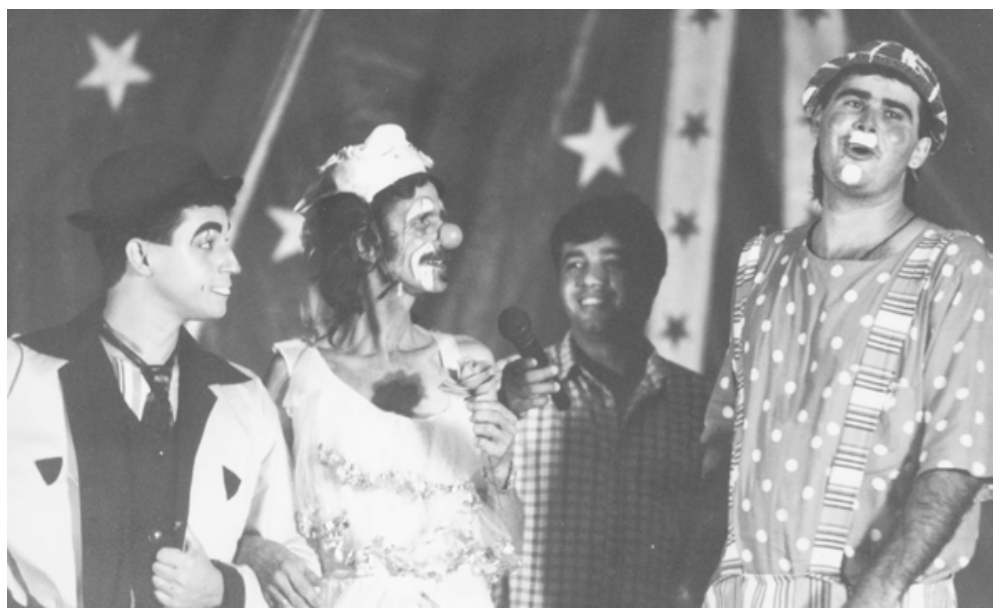

do se despia em cena, como ocorreu com a entrada "A noiva", o contraste se realçou. Nariz vermelho e uma bengala o acompanhavam.

Jurubeba sempre cultivou o improviso. Não se conformava com o repassar do script, pura e simplesmente. Para ele, o picadeiro era o espaço de exercício da liberdade criativa, em sintonia com a plateia.

Infelizmente, no dia da visita ao Circo Sandriara, acompanhando o ritmo desmotivado do espetáculo, Jurubeba e Bochechinha, o segundo palhaço da companhia, não tiveram um desempenho exuberante. Limitaram-se a reproduzir, quase que mecanicamente, os principais tópicos das entradas que escolheram. A visão do artista acerca de si e da profissão não se efetivaram na cena.

\section{Entrevista}

Não gosto de script: o negócio é livre, se liberado, eu crio na hora ali. Eu vejo que eu falo, conto uma piada, e não agradou, então, eu já não vou contar aquela mais. Eu procuro outra.

Ser palhaço é uma profissão que não é fácil. Você tem que gostar muito. Às vezes, cê sai na rua, nego chama: "Palhaço!". Você se ofende? Não, ao contrário, eu me sinto orgulhoso. Você, ou qualquer um 
no caso, vem no circo, vê eu trabalhar de palhaço e a gente se encontra na rua, ou uma criança, e chama eu de palhaço - tem gente que se ofende, eu não... - eu me sinto bem, eu me sinto bem porque eu fui palhaço, fui não.... sou até hoje. Palhaço, a obrigação dele é transmitir alegria, não pra ter inimizade com ninguém. Pelo contrário, ter mais amizade. Muita gente vem no circo pela amizade que você pega fora do circo, na cidade: "Vou lá ver o palhaço do circo, conversei com ele aqui, vou lá!", e muitos vêm...

Não é o Valdir, é outra pessoa, o palhaço Jurubeba. Minha obrigação é palhaço. Então, eu tenho que rebocar a cara ali e fazer. $\mathrm{O}$ Jurubeba é obrigado a ser criança, porque ele depende da criança, porque, pro personagem, não tem velho, nem moço, ele é tudo. $\mathrm{Na}$ rua é diferente. Na rua eu sou Valdir; no circo, da cortina pra dentro, é o Jurubeba.

[Jurubeba] É um moleque, tem que ser. Porque o palhaço não pode ser um morto, um velho lá dentro. Se ele é um palhaço velhão, lá dentro ele volta a ser criança. $\mathrm{O}$ velho, a pessoa que tá dentro do circo ele volta a ser criança, por causa do palhaço.

Branco em volta da sobrancelha e em volta do lábio, o vermelho e o preto também - muito importante. O nariz, que é uma coisa que muitos palhaços hoje não tá usando, mas eu uso, eu comecei assim, então eu não tiro ele. Se eu fico sem o nariz de palhaço eu me sinto pelado lá no picadeiro, e se não tiver a bengala também, eu tô pelado.

Comigo é assim, à vontade. Eu nunca gostei de ficar preso no picadeiro. $\mathrm{O}$ picadeiro de circo, pro palhaço, não pode ser prisão.

$\mathrm{O}$ circo grande leva mais reprise. O circo pequeno é mais entrada, comédia, show radiofônico. Circo grande não tem nada disso, é um número atrás do outro: leva um número, solta o palhaço, leva outro número, outra reprise... Então, é mais intercalado. Eu sou de circo pequeno. Gosto mais de circo pequeno pra trabalhar. 



\section{9 \\ Circo Beto Carrero}

\section{O espetáculo em Assis}

Primeira parte: Abertura; Arame alto; Chimpanzés; Paradas de mão; Reprise de "O apito", com o palhaço Nenê; Magia; Lira; Rola-rola; Globo da Morte.

Segunda parte: Cavalos amestrados; Nenê em "O caçador"; Corda indiana, Bicicleta; Saltos acrobáticos; Bambu; Nenê em "O futebol"; Trapézio Voador.

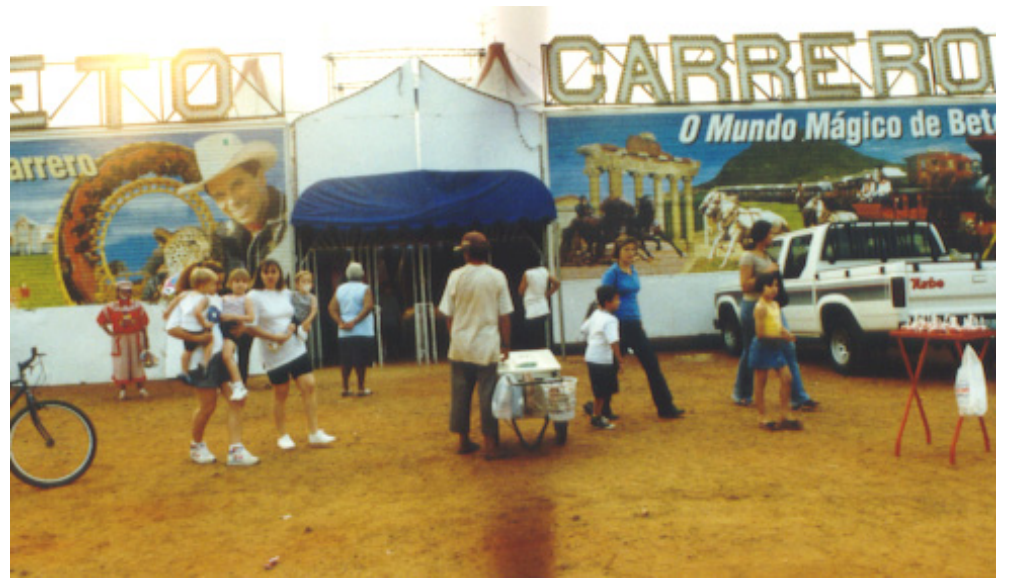




\section{MARIO FERNANDO BOLOGNESI}

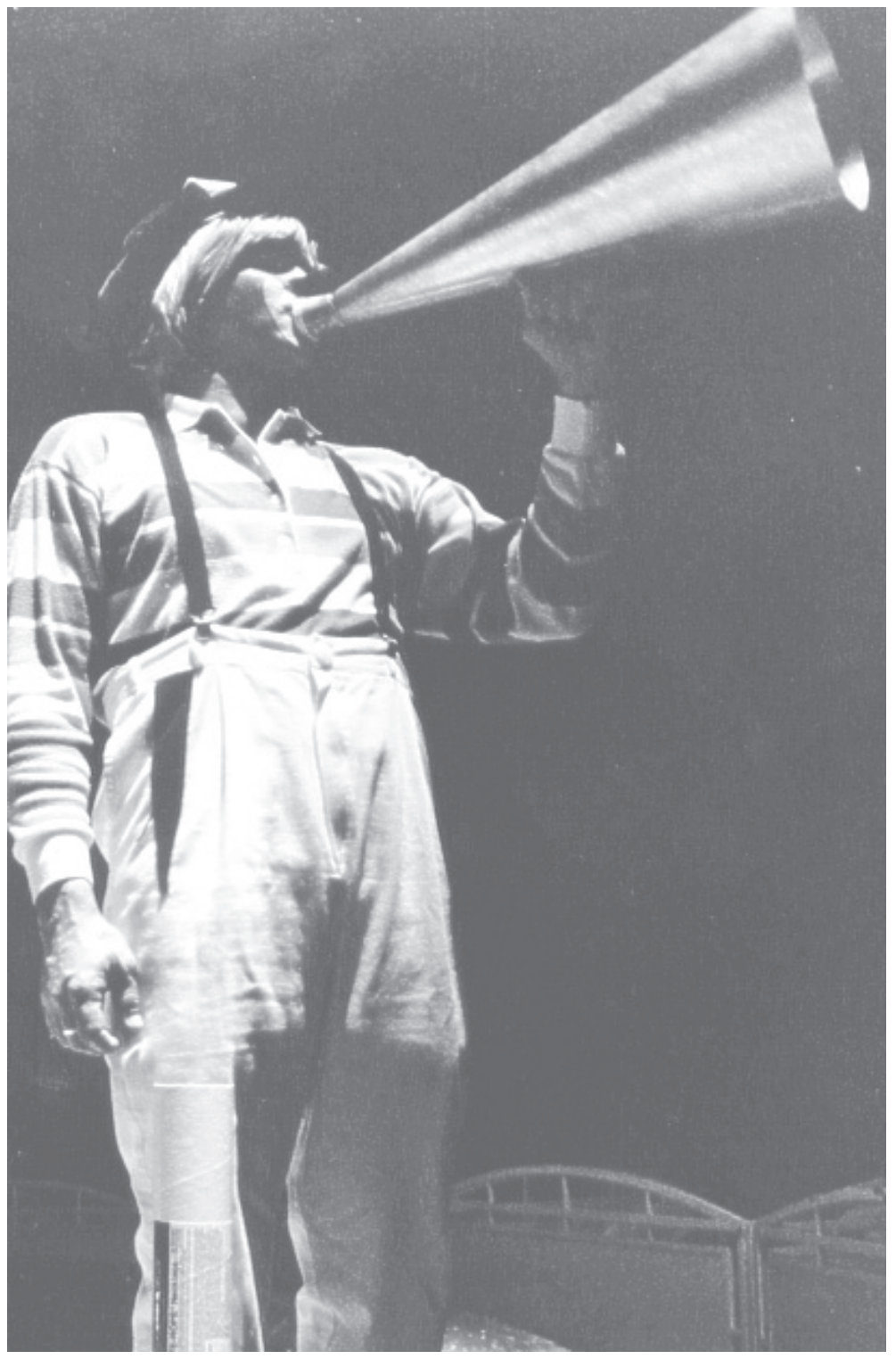




\section{O espetáculo em Marília}

Primeira parte: Palhaço se prepara; Apresentador; Leões. Cremoso e Charlequito em "O apito"; Cães amestrados; Número equestre; Força capilar; Número equestre; Equilíbrio de malabares.

Segunda parte: Báscula; Cremoso e Charlequito em "O atirador de facas”; Magia; Deslocação; Equilíbrio; Chimpanzés.

O Circo Beto Carrero foi visitado em duas oportunidades. A primeira, em 25 de abril de 1998, em Marília-SP; a segunda, na cidade de Assis-SP, em 29 de agosto de 1999. Tratava-se, contudo, de duas companhias distintas. Beto Carrero é a marca de seis companhias que viajam pelo Brasil.

Quanto à estrutura física, os dois circos visitados eram grandes, muito bem-arrumados e com muitos recursos sonoros e visuais. Os espetáculos ostentavam perfis de grandeza. Percebia-se que o empresário fazia uso da mesclagem entre números de primeira linha com outros de qualidade inferior. Contudo, para um espetáculo montado nos moldes tradicionais, não chegava a decepcionar. Por estes aspectos, a companhia vista em Marília era superior àquela que se apresentou em Assis. A estrutura de ambas era totalmente empresarial. Havia um rodízio de artistas entre as várias lonas do mesmo empresário, por todo o País.

A companhia que esteve em Marília tinha como palhaços os experientes Cremoso e Charlequito. Eles apresentaram reprises e entradas mais próximas do gestual, com poucas falas, o que denotava a sintonia dos artistas com o público, em decorrência, principalmente, das dimensões do circo. No espetáculo em Marília, pôde-se ver uma peculiaridade: antes do início, Cremoso, que até então era um vendedor de lembranças do circo, foi ao picadeiro (que estava com a jaula montada) e, diante de uma mesa e um espelho, terminou sua caracterização. O básico da maquiagem já estava pronto. Alguns retoques finalizaram a máscara da personagem. $\mathrm{O}$ acréscimo das roupas e da boina completaram essa sutil performance. Uma vez pronto, com um megafone, anunciou o espetáculo. 

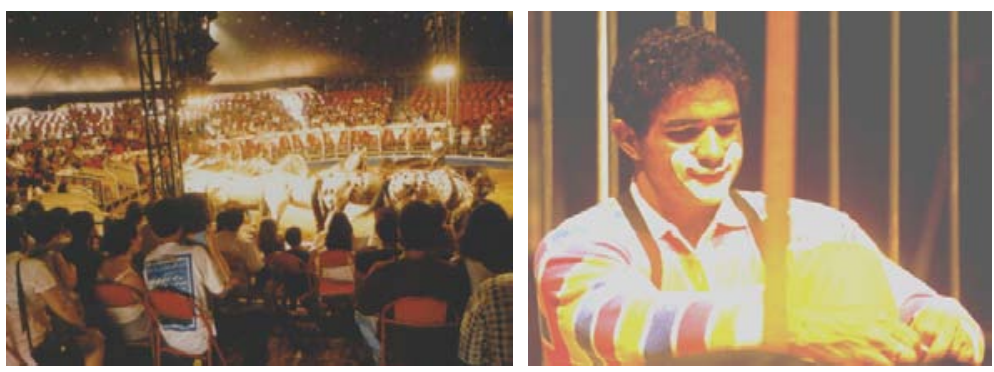

Além da performance inicial de Cremoso, os palhaços tiveram três participações no espetáculo. A primeira, com “O apito”. Na segunda, os cômicos apresentaram uma versão muda de um número de malabarismo. Por fim, na segunda parte do espetáculo, eles encenaram "O atirador de facas", com participação da plateia.

\section{Cremoso}

Júlio César Medeiros, o Cremoso, nasceu em Maceió-AL. Em 1998, quando foi contatado, tinha 29 anos de idade, com dezoito de profissão. Atuou no Nordeste brasileiro, em circos pequenos e afirmou que a experiência é mais aconchegante, simples e "apimentada". O medo de altura fez que se dedicasse somente à arte do palhaço. Cremoso dominava a expressão gestual. A experiência em circos de vários portes, com espetáculos distintos, tinha propiciado o aprimoramento do gesto no grande picadeiro.

A vestimenta de Cremoso era composta por tonalidades suaves, predominando o amarelo, o vermelho e um tênue azul na camiseta. Uma calça não muito larga, com suspensórios, completava o figurino. A maquiagem cobria apenas a boca, com pequeno destaque em negro para as sobrancelhas. O nariz era preto. 


\section{Entrevista}

Eu posso dizer que, em 92, eu tinha - eu trabalhava num circo pequeno - uma maquiagem superfeia, chamada de borboleta, porque cobre toda a face. Aí, eu fui aperfeiçoando, passei pra uma menor. Depois, eu cheguei até o Circo Garcia, aperfeiçoei mais a maquiagem e as roupas também. A gente vai tendo ideia, vai vendo fitas de circo lá fora e a gente vai tirando modelos e, assim, eu cheguei até aqui.

A maioria da minha vida foi em circo pequeno, sempre circo de 20 metros, redondo. Eu acho bem melhor que estar no circo grande, é uma coisa supergostosa. Você tá ali, superpertinho do público, cê pode brincar com o público. Aqui, você pode brincar, só que nem tanto, você tem um limite.

O circo fica todo claro e você nota, em todo público, a face, como é que ele tá reagindo, se tão rindo, se tão de cara fechada... Ontem mesmo, foi um dia maravilhoso: tinha uma senhora no camarote aqui, não parava de rir, não parava. Entre eu e o outro palhaço, Charlequito, uma festa. Pra gente, isso ai é uma alegria. É mais que um reconhecimento, um pagamento, é ver o sorriso do público.

O palhaço, digamos assim, é a alma do circo; quer dizer, a alma do circo é o público, só que, dentro do circo, a alma de um circo é o
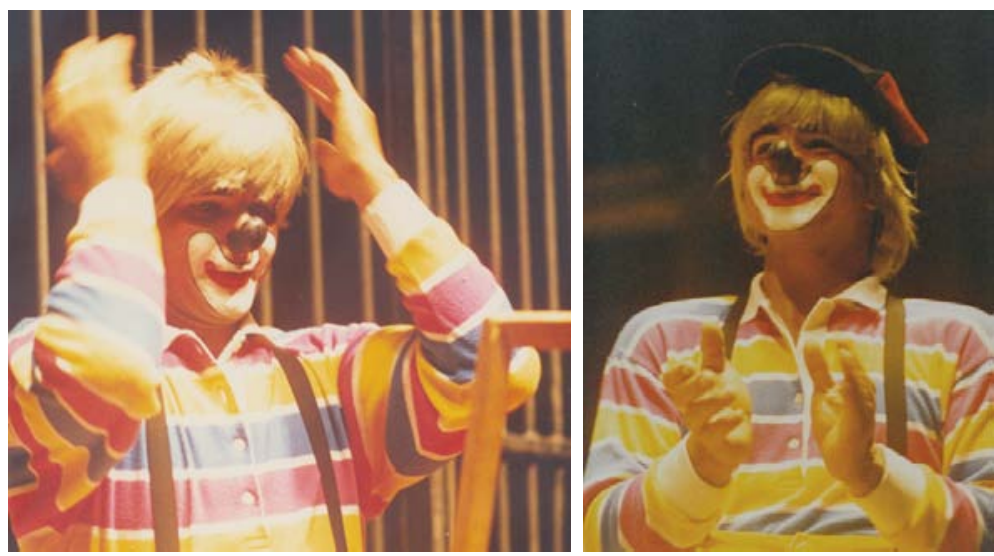
palhaço. Tudo sobra pro palhaço, não dá pra ir um número, estica, estica... o palhaço tá lá pra cobrir; faltou luz, põe os palhaços pra cobrir; ah! tá trocando de roupa, estica mais, o palhaço tá pra cobrir. Então, tudo se resume ao palhaço, e o palhaço não é reconhecido como deveria ser. Às vezes, eu me sinto chateado por isso. Mas não sou eu quem vou revolucionar isso aí; quem tem que ver são os empresários. Existem palhaços bons, existem ruins, eu sou o médio, nem bom e nem ruim.

A gente raramente ensaia. Mesmo que chegue palhaço novo, se diz: "Ah! eu levo tal coisa, assim, assim". Então, aquilo ali a gente dá só umas duas passadas; não é preciso ensaiar. Quando tem alguma coisa nova, uma reprise nova, então aí a gente ensaia um mês, dois meses, pra que saia perfeita, né!

Eu só queria agradecer por esta oportunidade, um trabalho superbonito que você tá fazendo com os circos e espero que continue fazendo isso por muito tempo, e deixar meu abraço pra todos. Espero que voltem e continuem, pra gente ser reconhecido e deixar alguma coisa pra mais tarde. Muito obrigado a todos vocês!

\section{Charlequito}

Manoel Naum Savala Monteiro, o Charlequito, nasceu no Chile. Atuava como palhaço desde 1952. Trabalhou em vários países da América Latina, em diferentes circos. Falava um português que trazia consigo as marcas de sua língua natal. Atuando no Brasil, viu-se impelido a explorar a mímica e a expressão corporal, o que, aliás, fazia com esmero. Quando participava de uma reprise e não era a personagem central da trama, em seu canto, com gestos sutis, chamava a atenção da plateia. A prática da profissão trouxe a necessária compreensão e o devido domínio do tempo do picadeiro. 

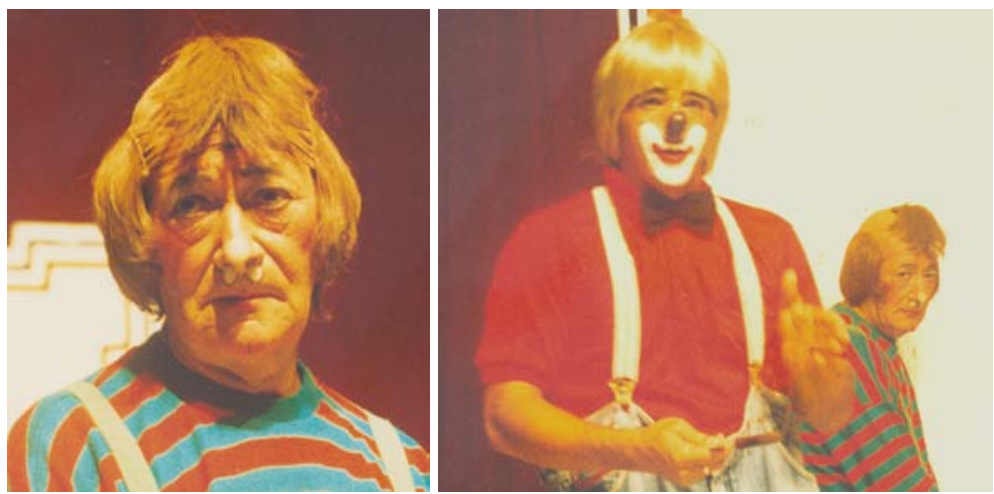

\section{Entrevista}

Tenho, atualmente, 63 anos. Ainda continuo trabalhando com entusiasmo, especialmente quando chego em um circo pela primeira vez, como acabo de chegar a este circo. O bonito disto é que, chegando aqui, encontro com um colega brasileiro, meu parceiro, e nos damos muito bem, vamos desenrolando nossas palhaçadas, nossas

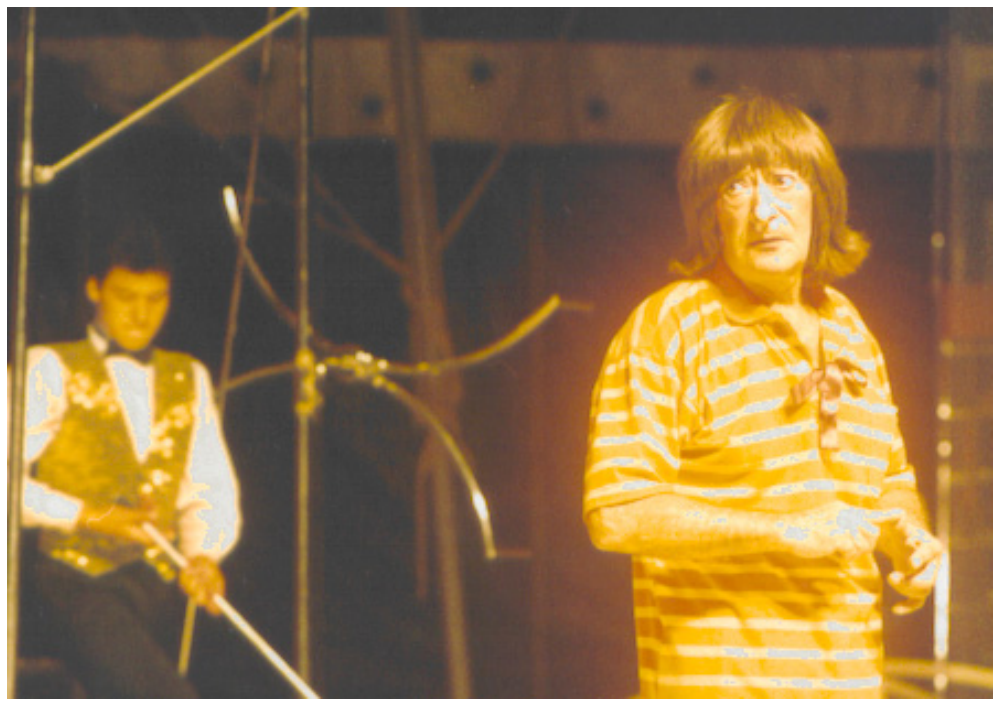



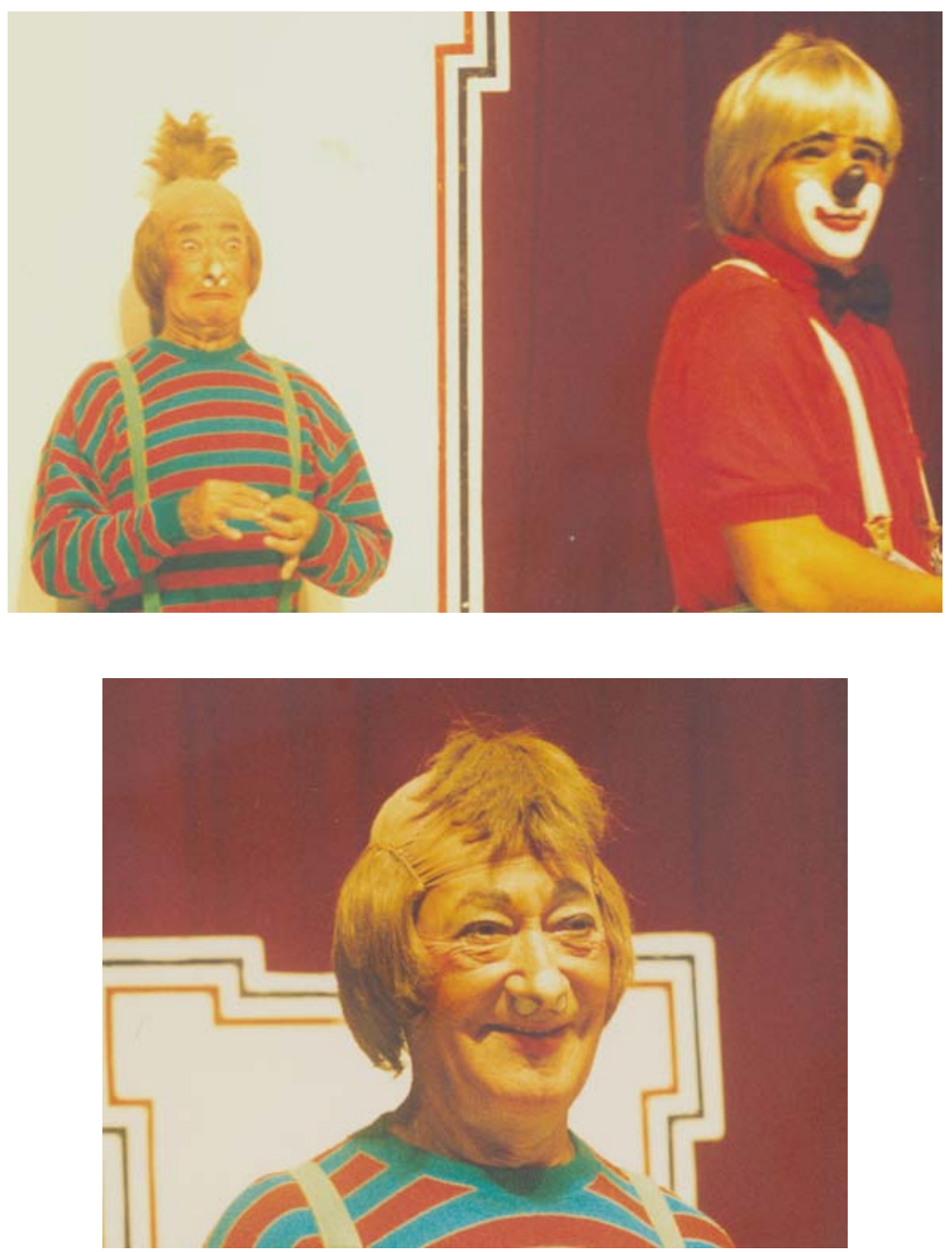

aventuras cômicas e, afortunadamente, o público retribui com aplausos, especialmente as crianças.

Trabalhei no teatro; alguns filmes também, em meu país. $\mathrm{Na}$ Argentina, também. Então, eu utilizo dentro do meu palhaço, utilizo muito a expressão, a mímica. 
Os palhaços, a maioria, é uma personalidade: cada palhaço tem sua personalidade. Eu elegi este tipo de personalidade que é um garoto, digamos assim, de mais ou menos 13, 14 anos, meio bobo e, digamos, essa é minha personalidade.

O palhaço tem que ter um pouco de psicologia, experiência de público para dar ao público o que o público necessita, o que quer.

A palavra bem brasileira não é muito domada. Então, por isso, utilizo muito a mímica porque a palavra me atrapalha muito falar.

Os gestos, no picadeiro, são mais exagerados do que no teatro. Tem que exagerar um pouco mais, porque o público está bastante distante de mim. No teatro, a figura está sempre de frente, aqui é no solo, para trás, para diante, para frente, enfim... Então, as expressões têm que ser mais ridículas, mais exageradas que no teatro.

O essencial é ter o circo lotado e que agrade. Colocar a alma pra fazer isso aí. Me desculpa, que deu a hora. Vai começar o show.

\section{Nenê}

Nenê participou três vezes do espetáculo. A primeira, em "O apito". Na segunda, com uma versão da entrada do "caçador”, adap-

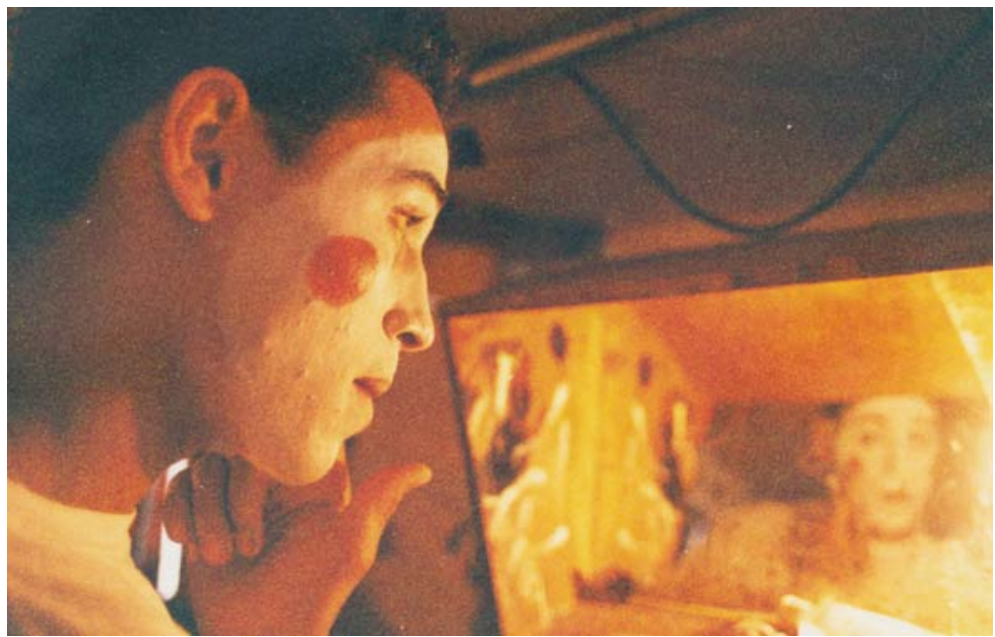


tando o roteiro para o personagem Indiana Jones. Por fim, ele levou a brincadeira do futebol, com intensa participação da plateia, momento em que o picadeiro era preparado para o trapézio voador.

Nenê tinha, na época, apenas 17 anos de idade e estava há pouco tempo na atividade cômica, embora tenha nascido em circo. Apesar da pouca experiência, o artista já demonstrava seu talento ao recriar roteiros, a partir de temas e imagens contemporâneas, a exemplo do Indiana Jones.

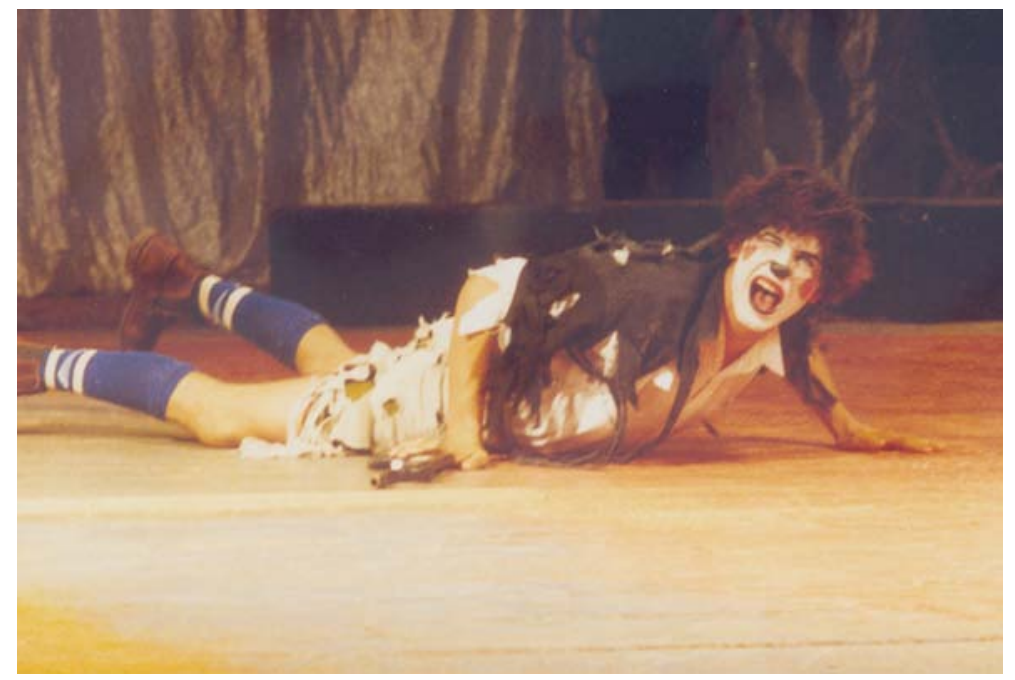

O nome de sua personagem era derivado do apelido de criança, dado pelo pai. A maquiagem foi inspirada em um outro palhaço, Xupetin, que também influenciou o modo performático do Nenê. Simples, ela apresentava uma mesclagem entre os tipos do clown Branco e o Augusto. Mantinha, do primeiro, a cobertura branca quase que total do rosto, com um longo traço negro que acentuava as sobrancelhas. O lábio superior era vermelho e o inferior, preto. Duas bolas vermelhas nas bochechas e o nariz preto achatado eram as principais evidências do Augusto.

Nenê reconhecia a importância do público para o momento do picadeiro. Havia, na atuação do artista, um chamar constante da 
plateia para participar com palmas e alaridos diversos, muitas vezes para denunciar a presença em cena de seu antagonista. Notava-se, também, a preocupação de adequar o figurino à natureza da reprise. Assim, três figurinos foram apresentados pelo artista. Em "O apito" ele entrou com uma camiseta verde e amarela, de listras largas, embaixo de um macacão branco, com pequenas estrelas amarelas, laranjas e vermelhas. No "Futebol", a cada momento ele apresentou o uniforme de um clube, do Flamengo, Corinthians, Palmeiras, Santos e, finalmente, da Seleção Brasileira. No Indiana Jones, ele se apresentou com um chapéu de feltro, uma jaqueta verde-escuro, calças brancas e cinturão, devidamente provido de faca e revólver de tamanho descomunal. Este vestuário "a caráter" foi aos poucos se desfazendo, trazendo à tona o palhaço maltrapilho, o caçador desastrado, de trajes surrados e rasgados. Para cada performance, o artista procurava gestos e atitudes características. Seus recursos gestuais, apesar de quantitativamente diminutos, foram explorados com rigor. 



\section{0 \\ Circo Brasil 2000}

\section{O espetáculo}

Primeira parte: Monociclo; Bonitinho em "O galo, a galinha e o pintinho".

Segunda parte: Comédia, "O casamento do Bonitinho".

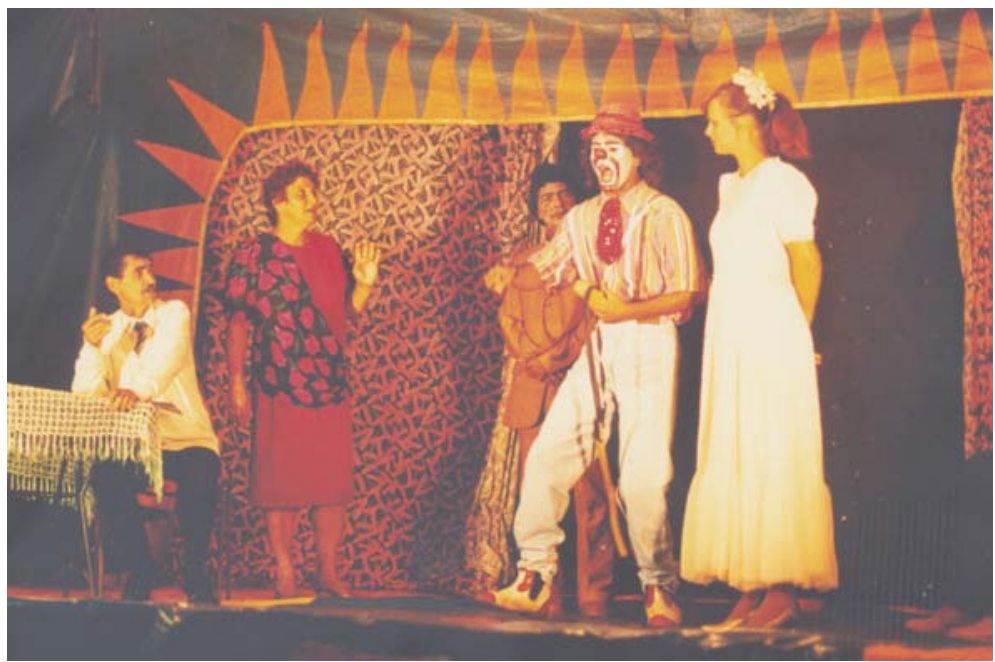


O Circo Brasil 2000 foi visitado no dia 26 de abril de 1998, no distrito de Frutal do Campo, município de Cândido Mota-SP. Tratava-se de um circo pequeno, de aproximadamente 26 metros x 32 metros, com estrutura precária e com poucos recursos de som e luz. No entanto, tudo nele era bem cuidado, com arrumação impecável, demonstrando boa organização. O espaço de cena era composto unicamente de um palco, em dimensões reduzidas. Uma cortina fortemente colorida, que se abria e fechava por sistema de roldanas e cabos de aço, dividia a cena dos bastidores. Desde o momento da entrada do público era possível visualizar um microfone fixado no palco, o que equivalia a dizer que o espetáculo seria voltado para cenas teatrais.

\section{Bonitinho}

O espetáculo teve no palhaço Bonitinho sua expressão máxima. Ele era muito jovem (em 1998 tinha apenas 17 anos), mas demons-

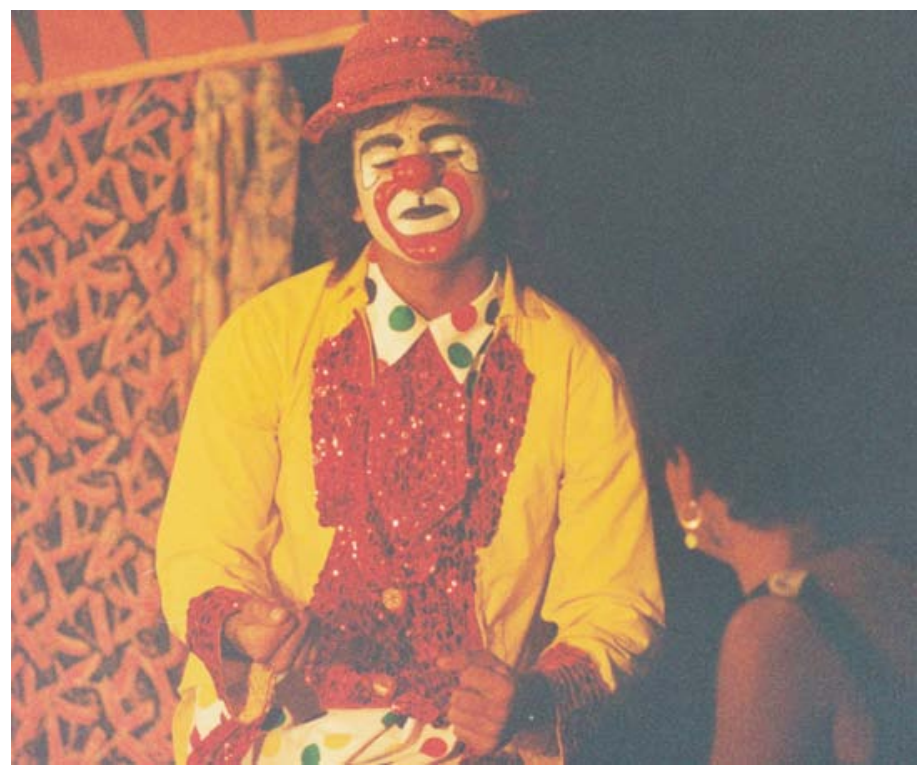


trou talento e expressão cênica suficientes para envolver o público, deixando-o atento ao enredo e envolvido nas graças do palhaço.

Bonitinho foi criado por Ailton Soares Macedo. Nascido em circo, ele participava das experiências teatrais da família desde os 6 anos de idade, o que proporcionou ao artista um aprendizado diversificado da arte do palhaço. Bonitinho tinha um perfil esnobe. A maquiagem era sobrecarregada no vermelho, ao redor da boca, que dava continuidade ao nariz vermelho artificial. Os olhos eram realçados por uma larga pálpebra branca.

Bonitinho direcionava sua performance para a interpretação teatral, tanto nas comédias propriamente ditas, que eram as preferidas do artista, como nas entradas e nos esquetes. Ele não era um palhaço que se apegava a gestos fáceis e também não explorava os gestos sexuais estereotipados. Procurava, a todo instante, trabalhar suas expressões facial e gestual para as necessidades do enredo, quer fosse ele imediato e simples, como nos casos das entradas, quer fosse mais elaborado, como nas comédias de maior fôlego. Para cada momento, ele adequava sua personagem ao exigido na cena. Assim, o palhaço Bonitinho estava presente na entrada e, na comédia, ele adaptou sua personagem a um rapaz caipira, que ainda mantinha os costumes da infância. 



\section{1 \\ Circo Roger}

\section{O espetáculo}

Primeira parte: Facas; Malabares; Corda indiana; Concurso de Dança; Reco-Reco em "Abelha, Abelhinha". Segunda parte: "O morto que não morreu".

O Circo Roger foi visitado em 22 de maio de 1998, na cidade de Catanduva-SP. Era um circo pequeno que estava se reorganizando,

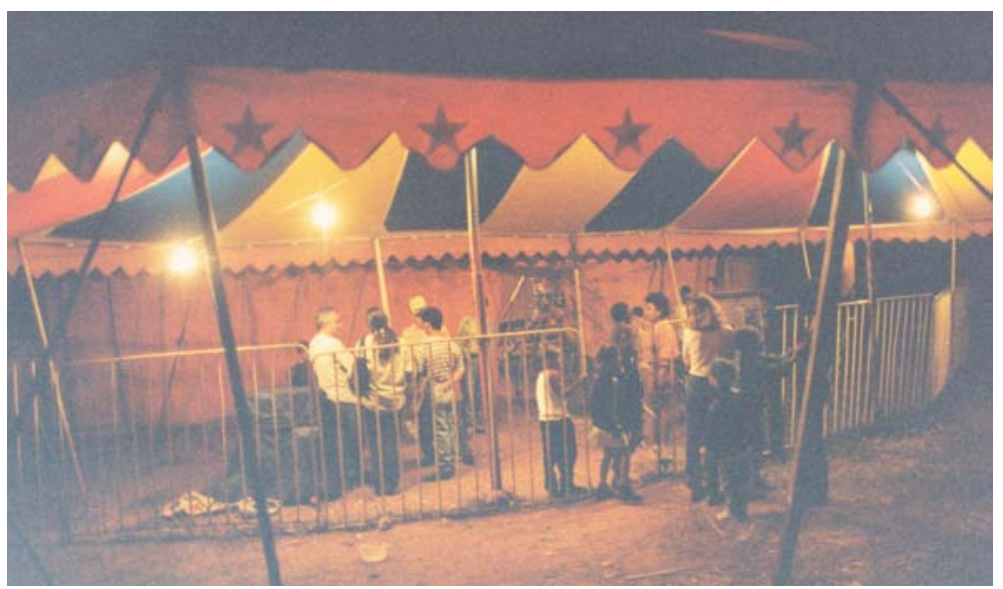




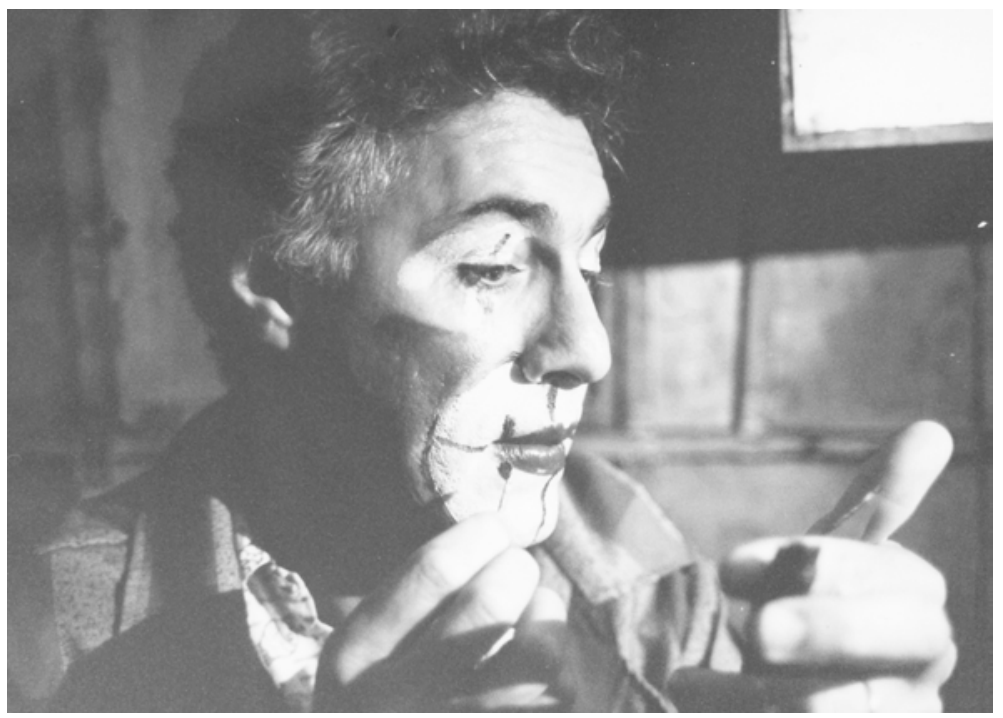

após um longo tempo de inatividade. O espaço cênico resumia-se a um tapete estendido sobre o chão. Os recursos de iluminação e de sonorização eram bastante precários. $\mathrm{O}$ público acomodava-se em uma arquibancada e algumas poucas cadeiras de madeira.

O espetáculo concentrou-se no palhaço Reco-Reco. Foram poucos os números circenses. Havia um clima geral de desmotivação no espetáculo, que se transferiu para o público da noite. Aos poucos, a plateia foi tomando conta do espetáculo, com gozações, interjeições e xingamentos generalizados. No picadeiro, tudo seguia seu curso normal, como se nada estivesse ocorrendo.

\section{Reco-Reco}

Nascido em circo, Nei Aires Neto, em 1998, tinha 39 anos de idade. Trabalhou como acrobata e trapezista. Aos 16 anos, começou a criar o Reco-Reco, uma personagem grande e abobalhada. O artista explorava devidamente sua alta estatura, fazendo de Reco-Reco um palhaço desengonçado, de raciocínio lento, porém simpático. 

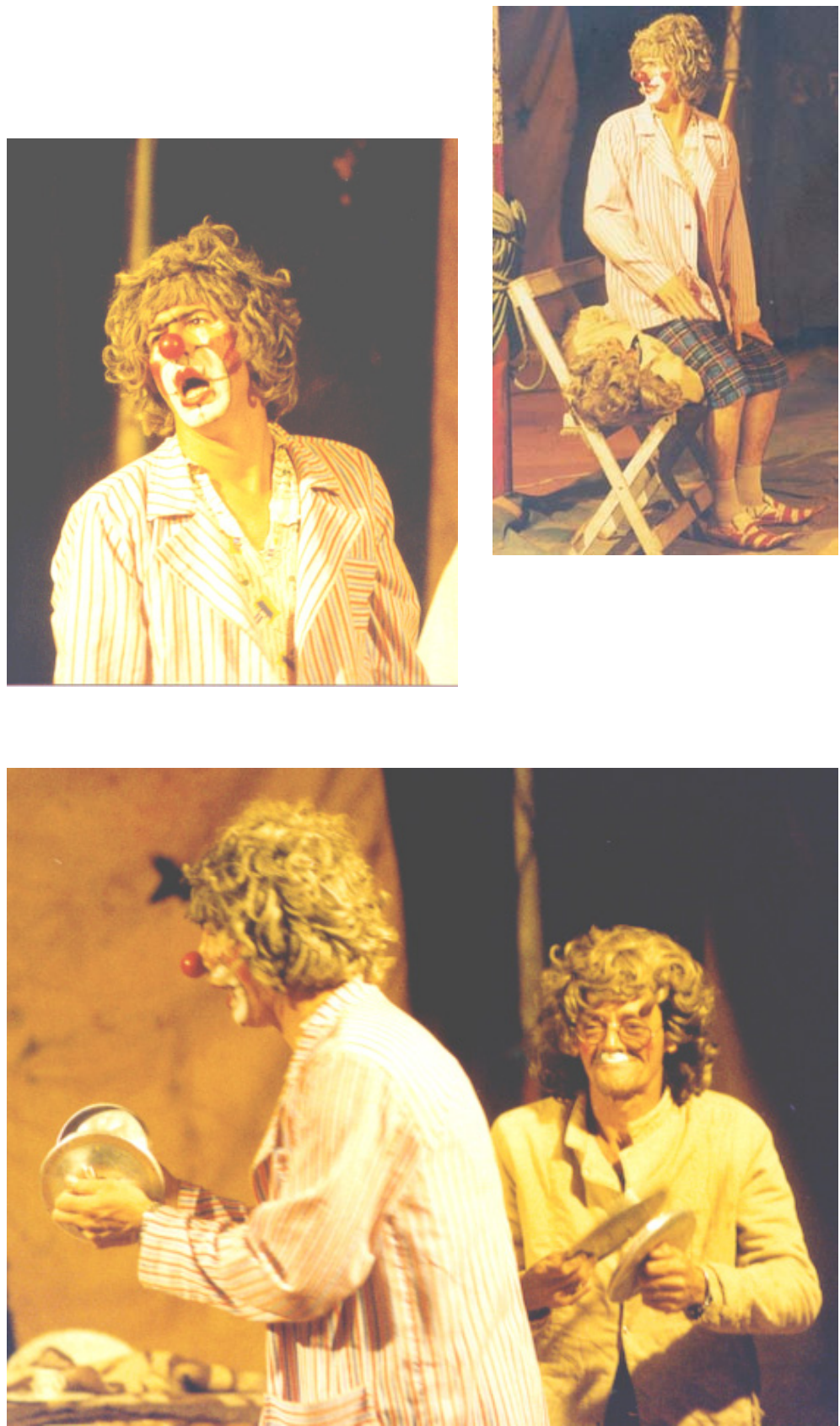
A cor amarela predominava no paletó do palhaço Reco-Reco, que trazia finas listras vermelhas e verdes, acentuando a estatura da personagem. O paletó era acompanhado de uma bermuda xadrez, com predomínio do azul, que atingia a altura dos joelhos. As canelas à mostra também enfatizavam a personagem que cresceu, mas não deixou de ser criança. A peruca era farta e cobria a testa até a altura dos olhos. Assim, restava à maquiagem ressaltar a boca e o nariz.

Reco-Reco demonstrou domínio da arte do palhaço, especialmente quanto ao tempo cômico. Isso foi possível de se observar durante a entrada "Abelha, Abelhinha". Na segunda parte do espetáculo, quando da apresentação da curta comédia "O morto que não morreu”, essa habilidade não se efetivou, prejudicando, assim, a interação com o público.

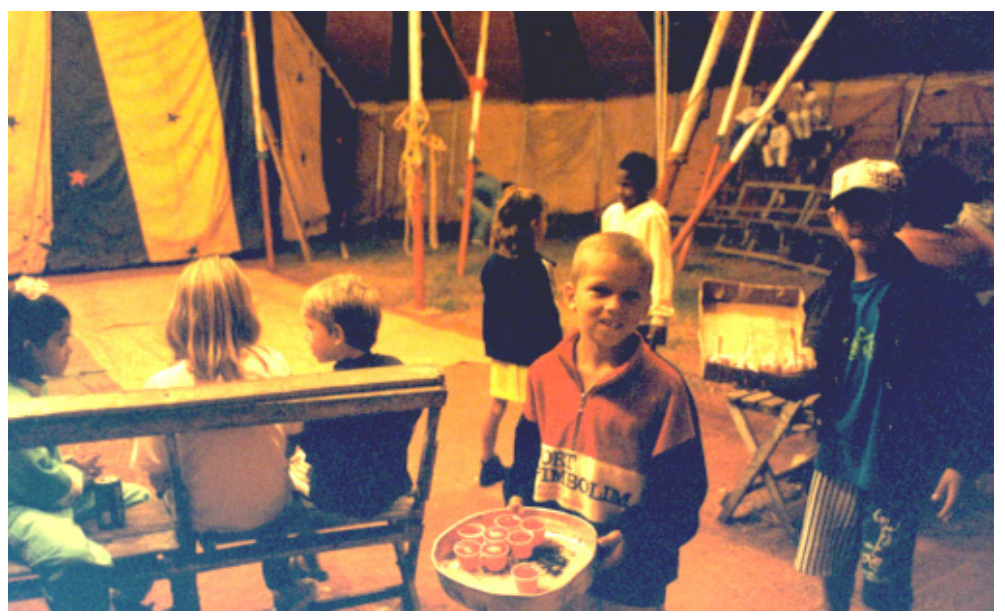




\section{CIRCO SPACIAL}

\section{O espetáculo}

Primeira parte: Apresentador; Rola-rola; Deslocação; Pingolé e Paçoca em "Salto mortal com a lata na mão"; Força Capilar; Excêntricos Musicais, Pirin e Pirina em "O concertista"; Equilíbrio e Paradas; Macacos amestrados.

Segunda parte: Trapézio Voador; Pingolé e Paçoca em "As lavadeiras"; Bailado - A dança dos planetas; Magia; Globo da Morte; Bailado; Apoteose.

Em 23 de maio de 1998, na cidade de Barretos-SP, foi encontrado o Circo Spacial. Era um circo grande, com muitos recursos de som e luz. Nele, todos os elementos eram voltados para o tema interplanetário, desde o visual externo até a iluminação, a trilha sonora, a concepção dos números, os elementos de cena etc. O figurino dos artistas combinava com o imaginário espaço sideral.

No geral, os números e os artistas eram bem preparados, técnica e artisticamente. Os palhaços Paçoca e Pingolé tinham um bom entrosamento cênico, com variações de figurino, de acordo com a temática do repertório levado à cena. Acompanhando o motivo espacial, eles também se apresentaram com cores metálicas, com pre- 


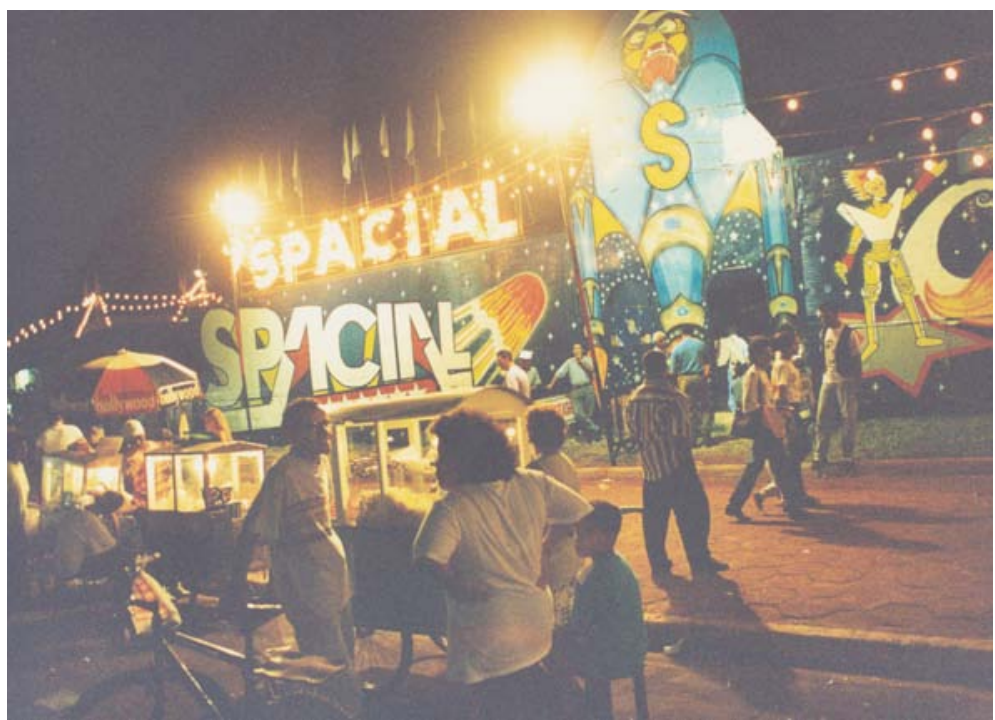

domínio do dourado e prateado. As reprises, contudo, como é próprio dos grandes circos, foram postas no roteiro de forma a cobrirem espaços para montagem e desmontagem de aparelhos para outros números.

Uma dupla de clowns musicais chilenos, Pirin e Pirina, participou do espetáculo com a entrada "O concertista".

\section{Paçoca e Pingolé}

Em 1986, nascia o palhaço Paçoca, criado por Antonio Quintino da Silva, oriundo de Juazeiro do Norte, no Ceará. No Circo Spacial, também trabalhava como motorista, nos momentos de viagem do circo. Não era de família circense e veio para o circo no ano de 1984.

Antonio Quintino, até 15 anos de idade não havia entrado em um circo. Foi chamado para transportar uma lata de água para uma senhora do Circo Stankovitch. Ficou para o espetáculo noturno para vender balas. Quando o circo se mudou, ele foi convidado a acompanhar a companhia, para vender balas na próxima cidade. Daí em 

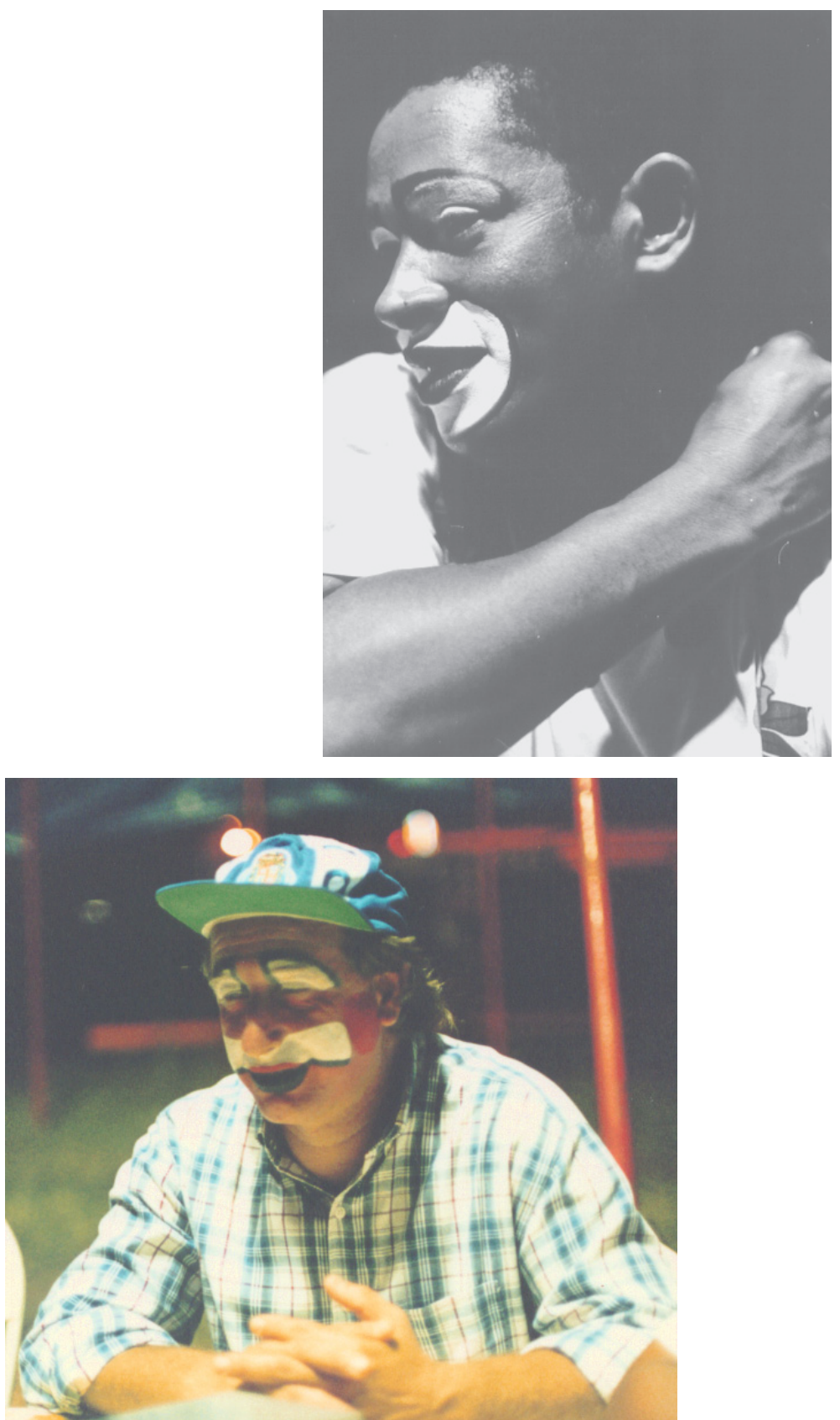
diante, nunca mais voltou. Tentou por várias vezes ser palhaço no circo que o tirou de Juazeiro. Contudo, segundo o artista, os proprietários não o incentivaram. Abandonou o primeiro circo e juntou-se a outro, na função de eletricista. $\mathrm{O}$ desejo de entrar no picadeiro como palhaço, entretanto, não esmoreceu. Certo dia, um palhaço necessitava de um parceiro, mas não queria ninguém que fosse da profissão. Chegara a hora do nascimento do Paçoca.

Pingolé foi uma criação de Gilmar Pedro Querubim. Em 1998, ele tinha 38 anos de idade. Além de palhaço, também exercia as funções de relações públicas do circo, estabelecendo contatos com a imprensa, com empresas e escolas.

Antes de dedicar-se à arte do palhaço, Gilmar era bancário. Integrou-se à vida circense no ano de 1986, na função de relações públicas. Em 1991, começou a desenvolver a personagem Pingolé.

O aprendizado de ambos deu-se no dia a dia, por meio da observação e da experimentação, contracenando com outros palhaços já experientes. Esteé, aliás, o procedimento natural da formação artística no circo. A personagem e o repertório vão aos poucos sendo estruturados e levados à cena.

Pingolé e Paçoca apresentam-se harmoniosamente. A aparência de ambos era semelhante, acompanhando o motivo das entradas e o tema geral do Circo Spacial. A preocupação pela harmonia manifestava-se também na interpretação de ambos. Havia entre eles uma alternância de funções. Ora um fazia as vezes do primeiro palhaço, o responsável pela graça ou pela ação atabalhoada, ora o outro.

As reprises encenadas pela dupla são conhecidas. Contudo, eles deram à cena um toque especial de interpretação. A todo instante, os artistas procuraram uma gestualidade que enfatizava a ação proposta. A grandiosidade dos gestos, assim, preenchia a movimentação dos barreiras no trabalho de desmontagem do Trapézio Voador. A atenção do público acompanhava o movimento dos palhaços que, nesse momento, optaram por uma reprise muda. 


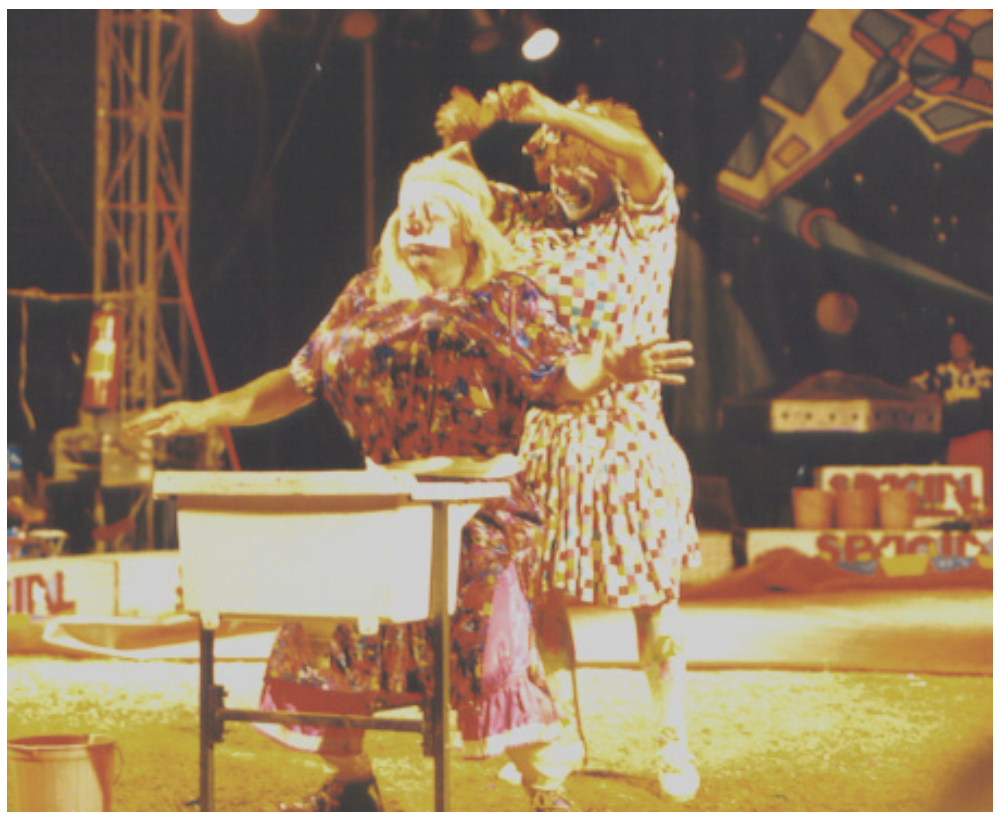

\section{Entrevista}

Paçoca: ...na hora que tá no picadeiro, a gente se transforma, realmente se transforma, faz de tudo para agradar a criança, e o que compensa é o sorriso da criança e o aplauso.

Pingolé: ...num sabia fazer nem maquiagem, não tinha sapato nem roupa, não tinha peruca. Me deram tudo isso. Foi feia a coisa viu. Todo mundo tem uma veia cômica dentro de si. Só falta soltar aquela veia dali. Na hora que eu pisei no picadeiro realmente foi feia a coisa, que eu tremi, ia falar, não saia a voz.

Pingolé: Sabe que no Circo Spacial sempre tem grandes palhaços e um dos rapazes que trabalhava no circo era o Xupetin, melhor palhaço do Brasil. Trabalhei com o Chumbrega, com o Braseiro, com o Bossa-Nova, com o Catatau, que foi um dos últimos parceiros que eu tive, trabalhei seis anos com ele. Eu fui aprendendo no dia a dia. A gente pode ensaiá, mas tem que dar uns improvisos porque, che- 
ga lá, você fala alguma coisa o pessoal não ri, e daí fala, você só tem aquilo pra falar. Então, você tem que ser meio cara de pau e falar mais coisa.

Paçoca: $\mathrm{O}$ meu aprendizado foi essa coisa do dia a dia do circo. Esse circo que eu trabalhava eu fiquei dois anos nele. Inclusive eu pedi pra entrar pra ser palhaço e falava com os donos do circo e eles falavam isso: "Não existe, nunca vi palhaço preto".

Pingolé: É... é difícil! O pessoal é muito antigo. Eles acham que a cor interfere muito no público. Mas não tem nada a ver: o que vale mesmo é o profissionalismo.

Pingolé: Eu tenho uma maquiagem diferente, parece que eu tenho até um esparadrapo grudado aqui. Mas não é não, é que hoje a maioria dos palhaços que se vê, a maquiagem é semelhante. Então, você tem que criar o seu próprio personagem.

Pingolé: O Gilmar é uma coisa, é um cara responsável, um cara que tá toda hora vendo os problemas do circo, tentando resolver alguma coisa, tá respondendo pelo circo. O Pingolé não. O objetivo do Pingolé é ver o público sair feliz. Quando eu entro no picadeiro eu esqueço o Gilmar, esqueço todos os meus pepinos e penso no Pingolé e esqueço o Gilmar. O Pingolé é totalmente divertido, brincalhão, cara de pau...

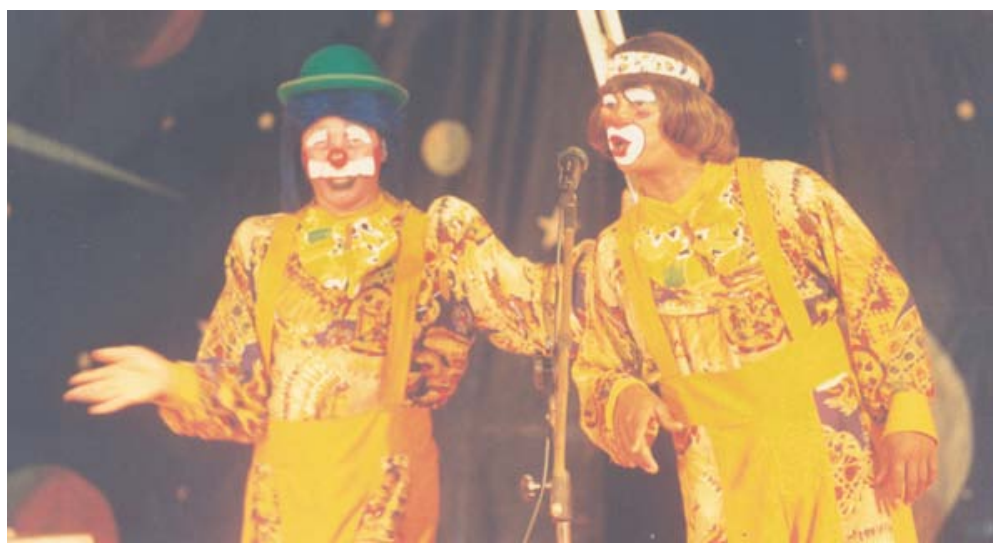


Paçoca: Acho que só existe o Paçoca, viu? O Antonio Quintino acho que deixou de existir bastante tempo, inclusive até no nome. Ninguém me chama pelo meu nome, e se chamar Antonio, eu fico sem saber: "Antonio, é você?" Ah, sou eu!

Pingolé: Eu acho que pra agradar o público não precisa usar a pornografia, fazer gesto obsceno. Então a criança vem aqui pra vê a brincadeira do palhaço. E se você for fazer uma brincadeira com gestos mais pesados, a criança vai chegar em casa vai fazer, você fala onde aprendeu isso? No circo.

Paçoca: E a criança chega em casa falando, uma outra pessoa vai perguntar: "Você foi no circo... e como que é?" "Ah! Não vale a pena não, o palhaço fala palavrão, passa coisas pras crianças que não vale a pena".

Pingolé: Existem palhaços que trabalham nesse estilo. Principalmente no Norte. Lá o pessoal usa muita pornografia. Então, lá pra cima, se você não for um palhaço meio cara de pau, você não agrada. Mas aconteceu da gente trabalhar no Norte. Tava com outro parceiro. Olha, recebemos elogio e não precisava usá gesto nenhum.

Pingolé: E o palhaço é assim, uma coisa assim fantástica. Se vai no jogo de futebol, reclama de uma coisa, o cara faz um erro lá, é um palhaço, que não sei o quê. Se o cara soubesse que o palhaço é uma figura muito carismática, uma figura muito difícil... Mas hoje mesmo existem palhaços muito bons por aí, mas o espaço da mídia é muito pequeno pra promover o palhaço.

Antigamente, chegava numa cidade pequena, chegava com desfile de animais, com carro de som e todo mundo sabia que o circo tava na cidade e chovia de gente pra vê o circo. Hoje não. Hoje mudou muito, hoje tem antena parabólica, TV por assinatura, tem o videocassete, tem a filmadora, tem shopping, o pessoal tem bilhões de divertimento pra ir. O circo ainda é um grande espetáculo que pode reunir todo mundo, pai, mãe, filho, vó, preto, branca, cheiroso, fedorento. Quer dizer, chega ali na plateia você pode ficar do lado de um cara muito famoso ou um cara simples também. E nosso maior orgulho é entrar e sentir que tá agradando pessoa que não sabe quem é, donde veio, e vai sair feliz. 



\section{3 \\ Circo di Napoli}

\section{O espetáculo}

Primeira parte: Avião; Equilíbrio de pratos; Macacos; Homem pássaro; Ursa; Cama Elástica; Paçoquinha em "Salto mortal com a lata na mão"; Elefante.

Segunda parte: Leões; Pôneis; Cavalo; Globo da Morte; Bailado; Paçoquinha em "Magia com patos"; Trapézio Voador.

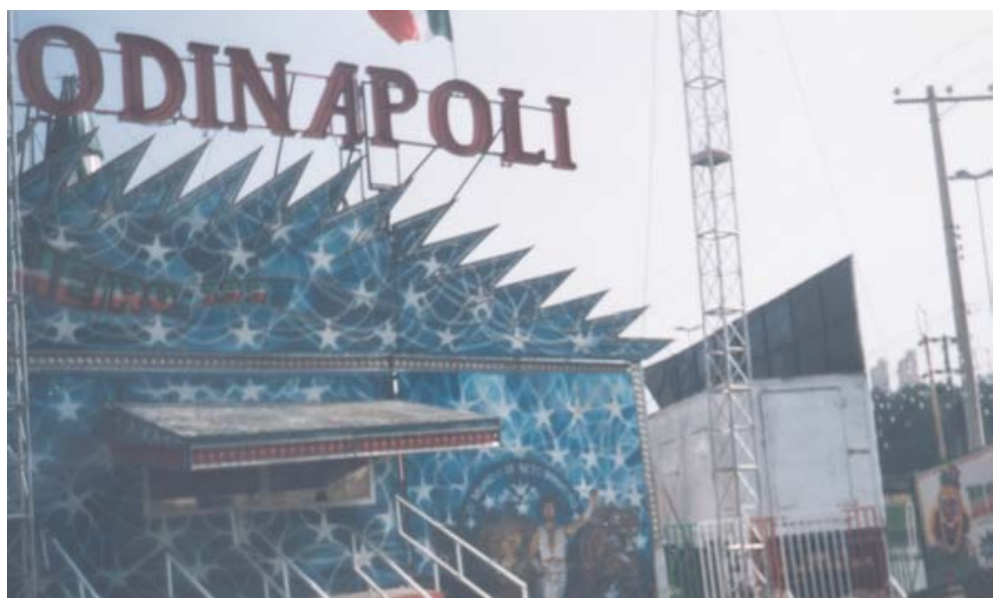




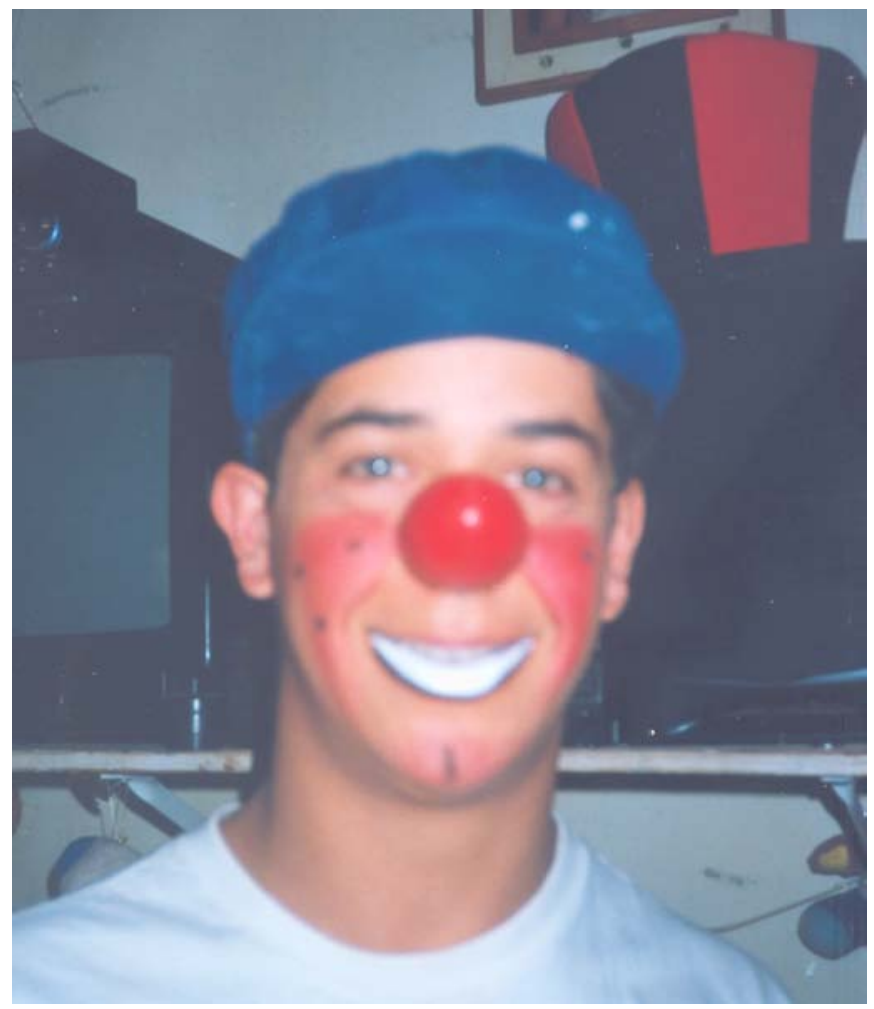

O Circo di Napoli foi visitado na cidade de Sorocaba-SP, em 27 de junho de 1998. Era um circo grande, com estrutura suficiente para um espetáculo grandioso. Como espaço cênico, o Circo di Napoli contava com um picadeiro de 13 metros de diâmetro. O público acomodava-se em arquibancadas duplas, cadeiras e camarotes.

O espetáculo era voltado para números circenses. Houve um predomínio de animais, alguns adestrados, outros apenas para exibição. No dia 27, o ritmo do espetáculo estava ágil. Porém, notou-se uma desarmonia entre a evolução dos artistas e os elementos sonoros e visuais dos números. Os artistas apresentaram-se com graça, beleza e elegância, o que compensava a fragilidade da técnica circense.

A apresentação dos palhaços agradou ao público. O riso era explorado a partir da combinação de vários elementos cênicos: roupas 
impecáveis, interação entre a dupla de palhaços, equipamentos bem montados e recursos musicais acertados. As reprises encenadas conseguiam, assim, desviar a atenção do público, enquanto eram desmontados e/ou preparados os grandes aparelhos, especialmente o Trapézio Voador.

\section{Paçoquinha}

Paçoquinha era o principal palhaço do Circo di Napoli. A personagem foi criada por Alexandre Francisco Pinheiro, que tinha 19 anos de idade. Ele desenvolvia sua habilidade cênica desde os 5 anos. Além de palhaço, também era acrobata e trapezista. Contudo, no Circo di Napoli apresentava-se apenas como palhaço.

Alexandre procurava um tipo infantil e ingênuo para seu palhaço. Isso se evidenciava no raciocínio lento e na postura às vezes abobalhada em cena. Infelizmente, não foi permitido o registro fotográfico do artista em cena. 



\section{4 \\ Circo Weber}

\section{O espetáculo}

Primeira parte: Cama elástica; Malabares; Caquito em "O balão"; Trapézio em Balanço; Equilíbrio cômico de pratos; Equilíbrio com taças; Caquito em "Magia com patos"; Pêndulo.

Segunda parte:Trapézio Voador; Caquito em "Brincadeira com crianças"; Turbilhão; Globo da Morte; Apoteose.

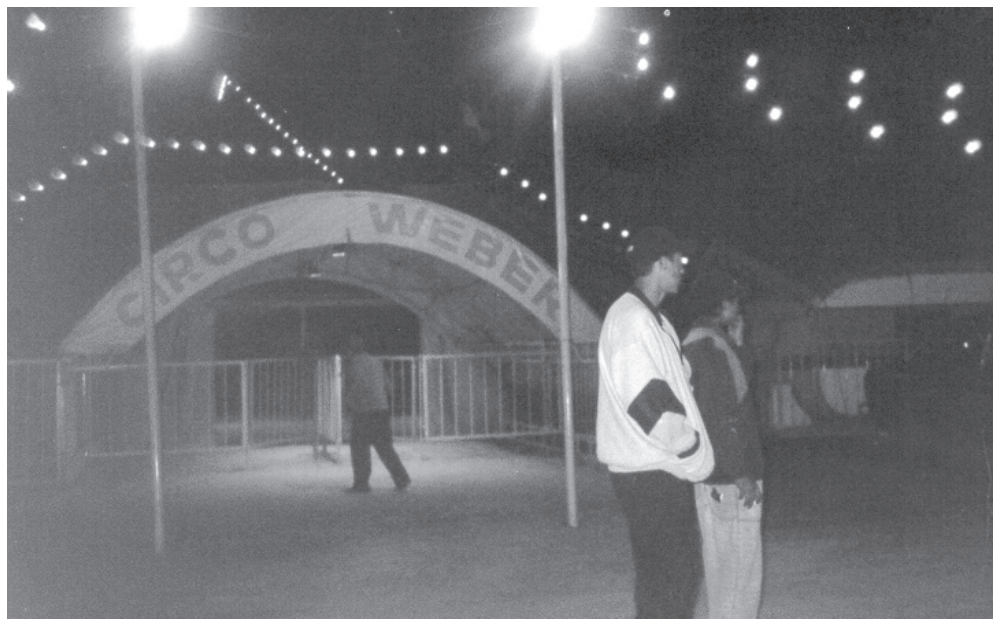




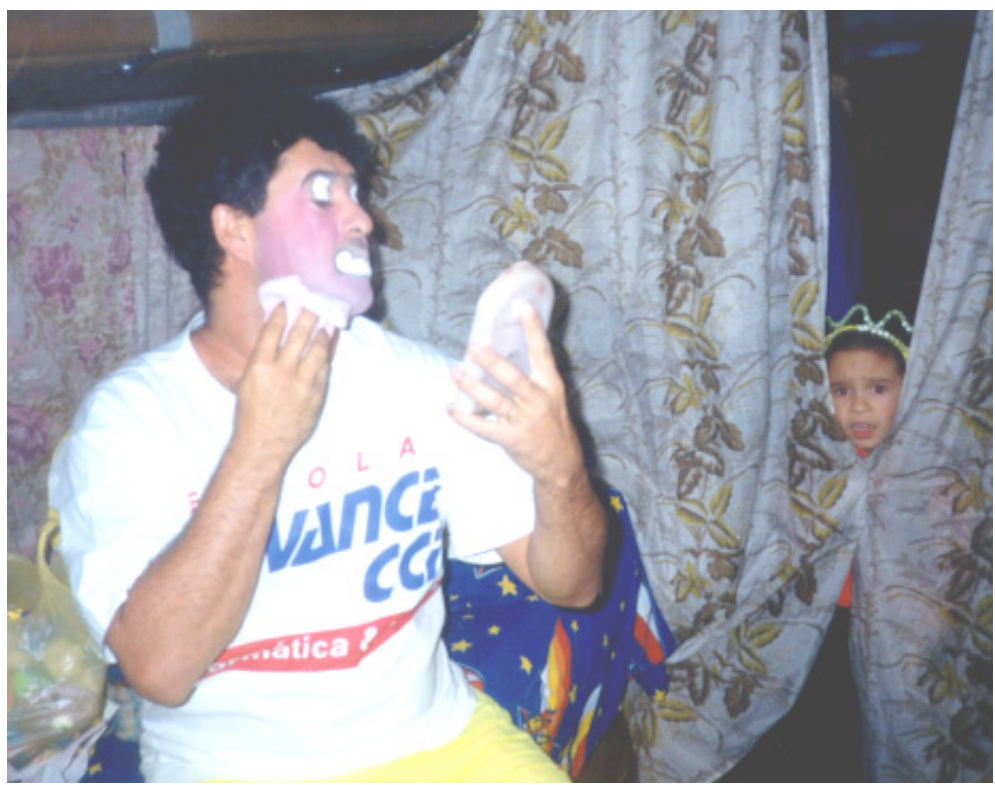

O Circo Weber foi visitado na cidade de Itapetininga-SP, em 3 de junho de 1998. Era um circo de grandes proporções, medindo em torno de 50 metros x 60 metros. O espaço cênico era composto unicamente de um picadeiro de 13 metros. O público alojava-se em arquibancadas, cadeiras e camarotes, divididos por uma cerca interna. Ele exibia uma fachada portentosa, de grande estrutura. No entanto, internamente, os recursos de iluminação eram fracos, o que terminava destoando, se comparados à arquitetura externa e interna do circo.

O espetáculo evoluiu sem um ritmo adequado, apesar dos números agradáveis, com os artistas demonstrando muito empenho e um bom domínio técnico. O figurino era dos mais discretos, porém muito bem cuidado, predominando as cores azul, branco e rosa.

As reprises apresentadas pelos palhaços agradaram ao fraco público da noite. Enquanto a dupla cômica se apresentava, outros números eram preparados. Houve um predomínio de aparelhos no repertório apresentado por Caquito. Os recursos sonoros e gestuais predominaram sobre as falas. 

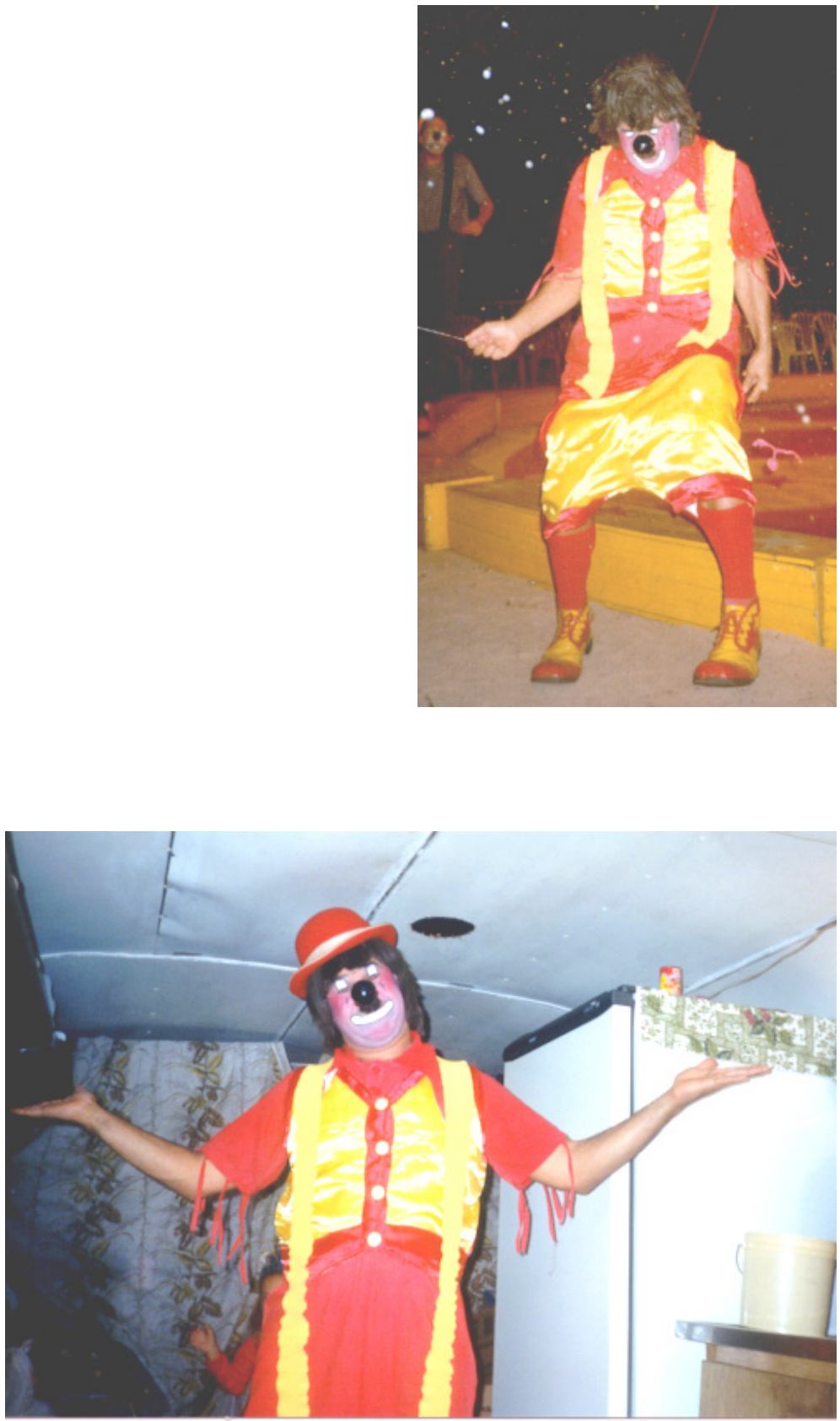


\section{Caquito}

Jurandir Rosalino Filho, o Caquito, nasceu em 1965, em Goiás. Aos 7 anos de idade, passou a se dedicar à arte do palhaço, seguindo a tradição da família.

Caquito teve uma boa performance cênica. Procurou atentamente evidenciar as reprises com gestos minuciosos e elaborados, que se congelavam em determinados momentos. Esses momentos coincidiam com a exploração dos roteiros das reprises e entradas. Com isso, além da graça própria do discurso linguístico, o artista conseguiu o enriquecimento e a ampliação do riso.

Sua vestimenta era composta de roupas largas, nas cores vermelha e amarela, sapatos grandes, peruca com cabelos não muito curtos. Seu tipo era alegre, folgado, bonachão, atrapalhado e com raciocínio lento. Já tentou compor sua personagem como uma criança, mas afirmou que não se deu bem, não se reconhecia na personagem. Ao adotar um tipo genérico, conseguiu conciliar sua aparição em cena com outras funções que exercia no circo, como por exemplo a de vender doces. Mesmo nesse momento, fora de cena, desenvolveu seu potencial artístico. Brincava com todos, em todas as situações.

Dois anos depois, em 2 de junho de 2000, Caquito foi encontrado trabalhando no Circo Miami 2000, na cidade de Coxim-MS. 


\section{5 \\ Circo Miami 2000}

\section{O espetáculo}

Primeira parte: Jaula com leoas; Caquito e Chuvisquinho (anão) em "Equilíbrio de pratos e ovos"; Magia; Urso; Caquito em "Magia com patos"; Lhamas; Bailado country com pôneis; Táxi Maluco. Segunda parte: Cesto; Caquito e Chuvisquinho em "Caveirão"; Trapézio Voador; Coreografia africana, com fogo e hipopótamo; Caquito e Chuvisquinho em "O fotógrafo"; Odaliscas e o dromedário; Globo da Morte; Arca de Noé (desfile dos animais, que entram em uma arca).

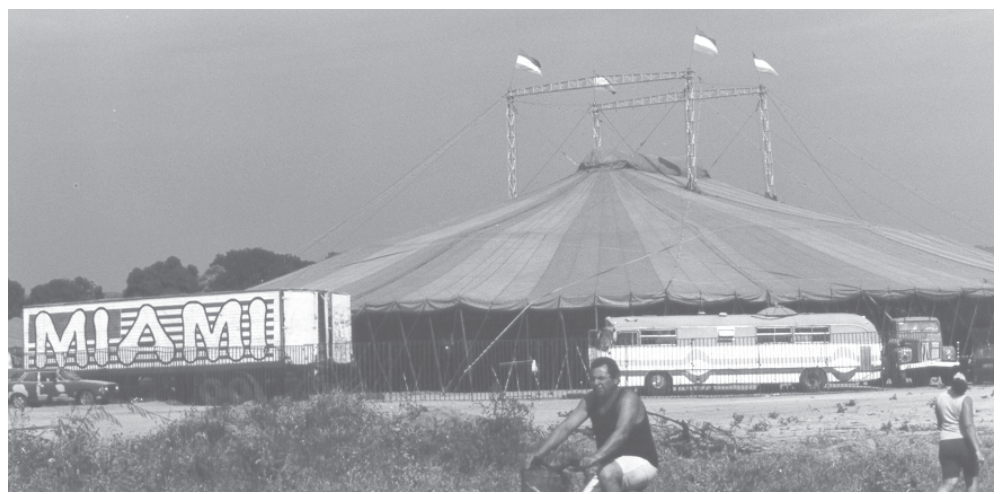




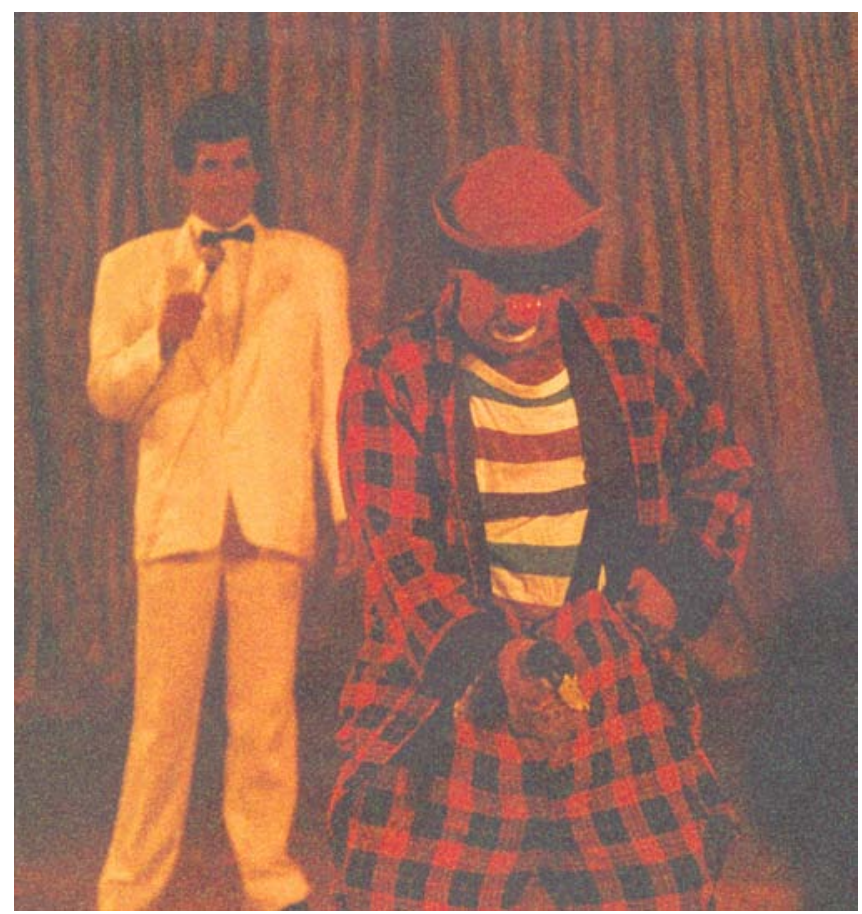

O Miami 2000 era um circo grande, de quatro mastros e cúpula oval. Media aproximadamente 60 metros x 80 metros. O espaço de cena era composto por um picadeiro de 13 metros de diâmetro, circundado por caixotes de madeira. O público acomodava-se em cadeiras, sobre estruturas de arquibancadas, divididas entre as centrais e as laterais. Havia também um pequeno espaço reservado para camarotes.

Apesar de grande, os recursos de iluminação não eram suficientes para contribuir com o espetáculo. Uma luz geral razoável era acompanhada de um conjunto de focos coloridos e um canhão ao fundo do circo, que destacava os elementos julgados especiais, no espetáculo. Igualmente à luz, a aparelhagem de som era insuficiente para a grandeza do espaço, o que terminava comprometendo a grandiosidade pretendida. 
O espetáculo apresentou um número variado de animais, como hipopótamo, dromedário, urso e lhamas. Eles, entretanto, eram postos em cena apenas para exibição, exceto o urso, que fez algumas evoluções em escorregador e cadeira de balanço. Os outros apenas desfilaram seu exotismo. Quando isso acontecia, a apresentação do animal era precedida de um pequeno bailado que evocava a origem do animal, a exemplo do hipopótamo, que foi apresentado por uma coreografia que lembrava o universo africano. Igualmente, o dromedário foi apresentado após a performance de algumas odaliscas.

Os palhaços esforçaram-se para atrair o público, o que acabou acontecendo. Caquito, especialmente, procurou a todo momento levar a cena até a plateia, envolvendo-a nas reprises.

Três reprises encenadas por Caquito merecem ser destacadas.

A primeira foi o "Equilíbrio de pratos e ovos". Inicialmente, o palhaço executou o equilíbrio de um prato, que era parodiado por seu parceiro com um prato furado e preso à ponta de um prego, em uma vareta. Em seguida, Caquito executou um pequeno malabarismo com um ovo, que se revelou de madeira. $\mathrm{O}$ parceiro procurou imitá-lo, porém com um ovo verdadeiro, que terminou quebrado. Em seguida, Caquito executou a passagem de um ovo de um prato para outro. Revelou-se a trucagem da apresentação: o ovo estava preso por um pequeno fio invisível, no chapéu do palhaço. Finalmente, Caquito tomou uma cesta de ovos, encaixada em uma vare-

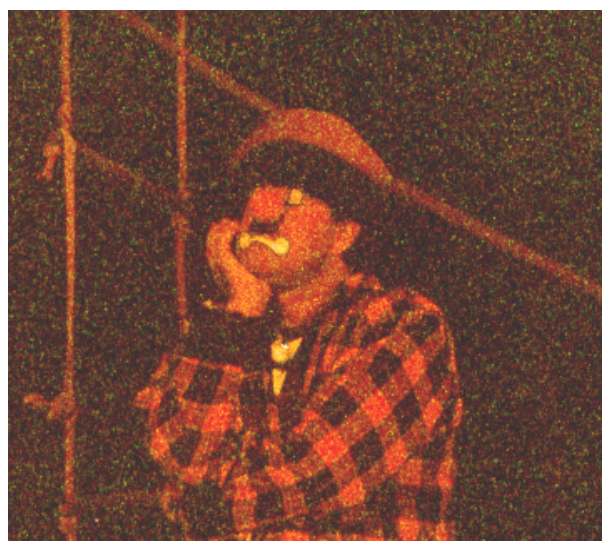



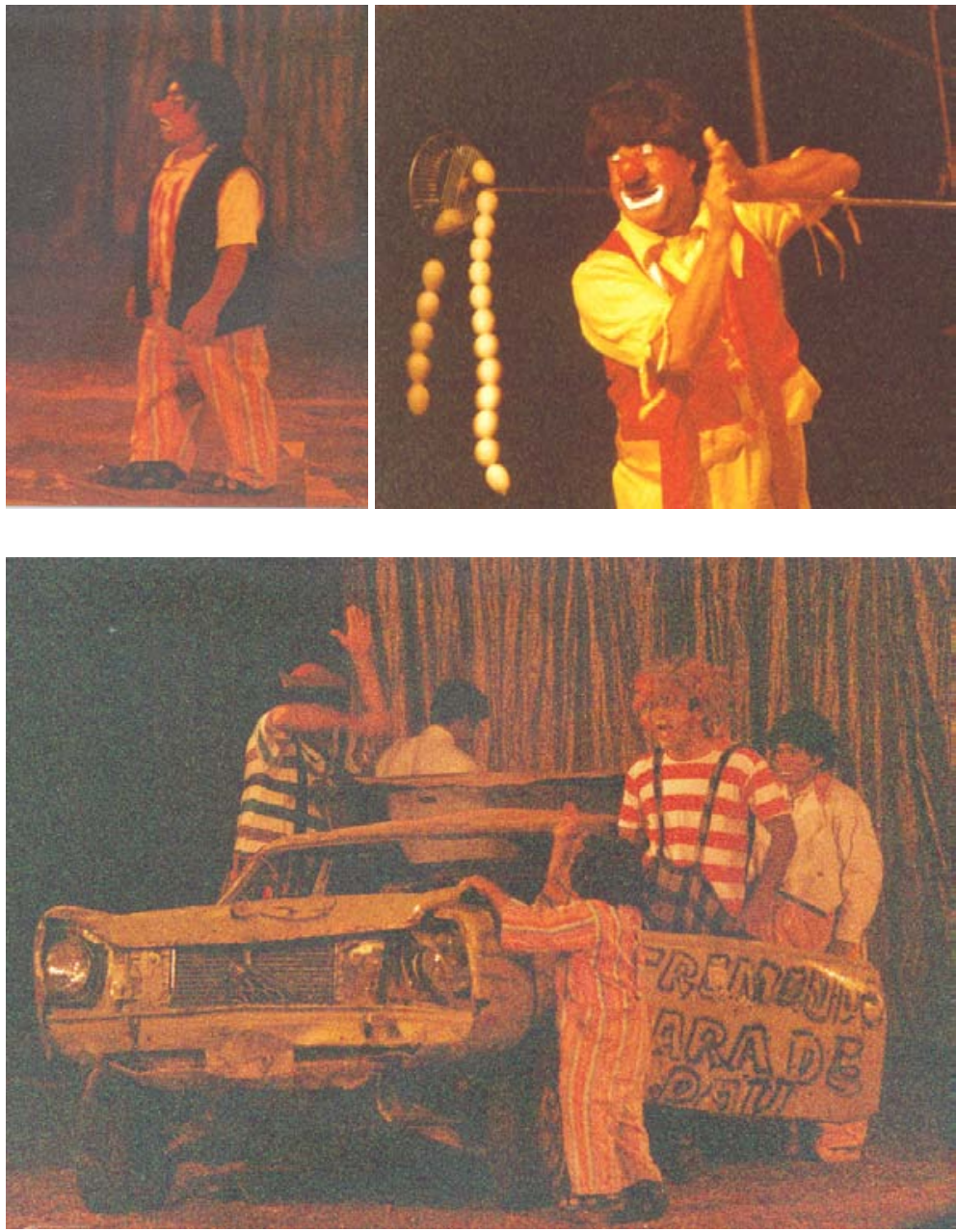

ta, equilibrando-a sobre o queixo. Em meio ao público, ele escorregou e os ovos caíram, mas estavam presos à cesta por um fio.

A segunda foi "O caveirão". O desenrolar do enredo é conhecido. Entretanto, ao final, diferentemente dos demais, ao invés de sair correndo, Caquito foi construindo seu medo aos poucos, vagarosamente, num crescendo depurado de gestos e sons ao microfone. Ameaçou fugir, mas não conseguiu. Ensaiou um diálogo com a ca- 
veira, que se apresentava como sendo o "tinhoso", que veio das profundezas para buscá-lo. Isso deu o ensejo para que a caveira se revelasse com intenções homossexuais, afinando a voz e oferecendo-lhe uma rosa vermelha. O palhaço recusou aquele flerte e a caveira saiu correndo ao encalço do pretendido.

Outra reprise que a dupla cômica encenou foi "Magia com patos". Nela, houve a exploração do duplo sentido, que era dado de forma exclusivamente gestual. Isto ocorreu no momento em que o palhaço escondeu em suas calças o segundo pato do número de magia. O pescoço e a cabeça do pato, para fora das calças, associavamse ao falo. Caquito, no entanto, não explorou o gesto másculo de forma extensiva e repetitiva.

Caquito sempre procurava acompanhar o sentido do enredo com gestos próprios. A cada entrada em cena, Caquito apresentava-se com uma roupa diferente, o que também caracteriza esse tipo de palhaço nos grandes circos. $\mathrm{O}$ artista tinha muito cuidado com os gestos paralisados, momento em que procurava sintetizar em uma expressão completa alguns dos sentidos do roteiro apresentado.

As aparições dos palhaços deram-se quase sempre nos intervalos de montagem de grandes aparelhos. O movimentar dos barreiras, o deslocamento das grandes partes dos aparelhos e a sonoridade que isso provocava eram elementos do espetáculo que provocaram uma "concorrência" aos palhaços. Caquito e Chuvisquinho, no entanto, conseguiram superar esses percalços. 



\section{6 \\ Circo Garcia}

\section{O espetáculo}

Primeira parte: Desfile de apresentação; Paradas de mão e de cabeça; Macacos amestrados; Contorcionismo, com participação de Kuxixo; Cavalos em volteio; Dândis; Cães amestrados; Pôneis.

Segunda parte: Tigres; Palhaços em "Os cozinheiros"; Trapézio Voador; Palhaços em "O boxe"; Elefantes; Encontro dos Palhaços; Apoteose.

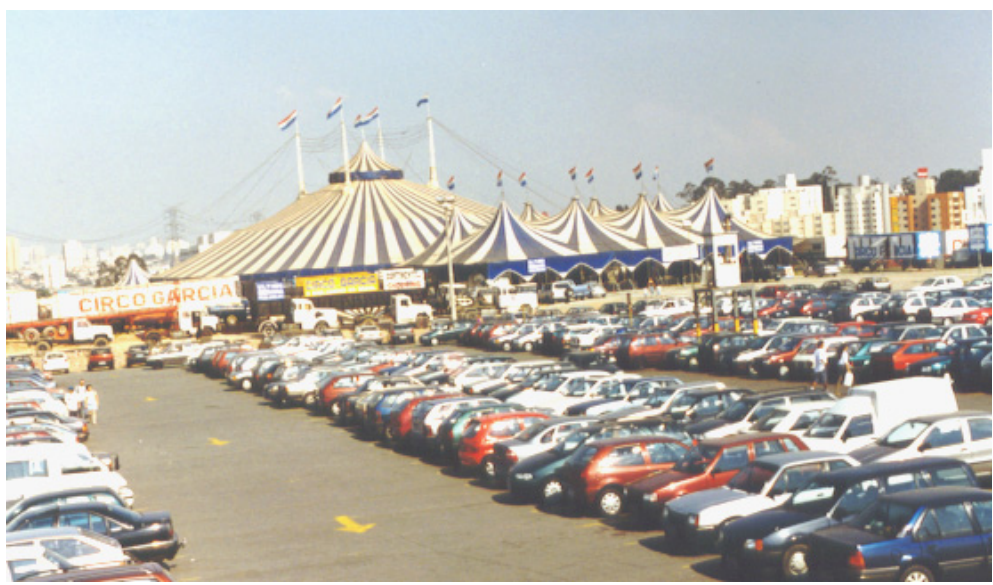




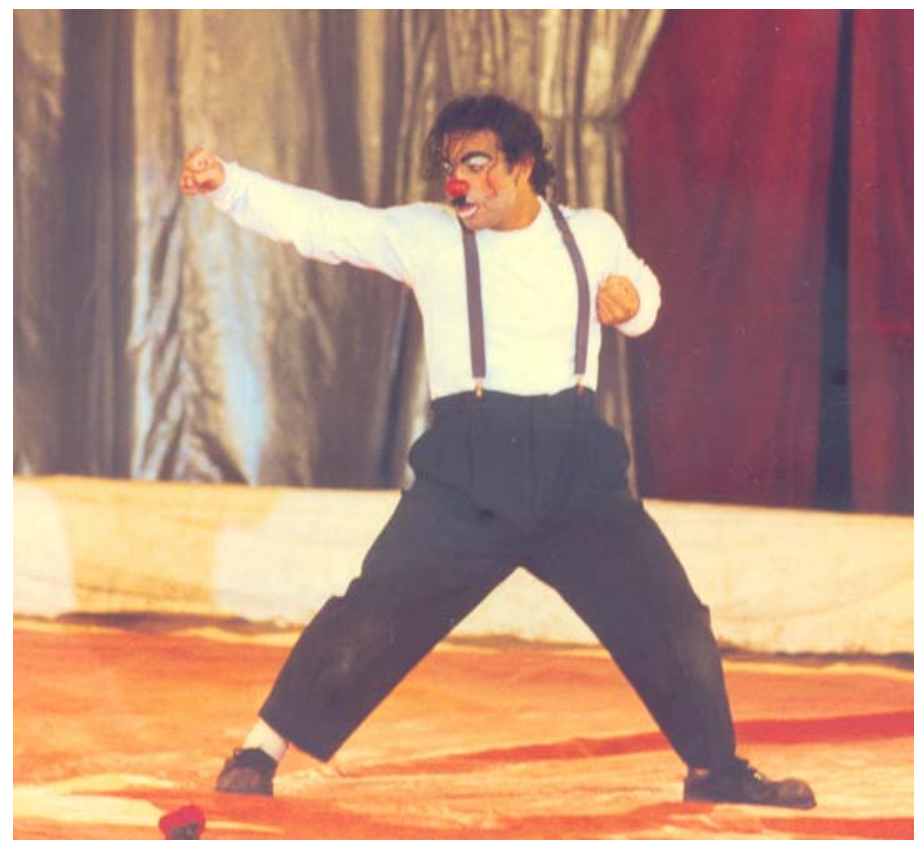

O Circo Garcia foi visitado na cidade de Osasco, em 31 de julho de 1998, e estava montado no estacionamento do Shopping Center Continental.

O Garcia era um circo grande, dos mais conhecidos do público brasileiro. A casa de espetáculo deixava transparecer uma organização cuidadosa, visível desde a arrumação interna até a apresentação dos barreiras em cena, todos eles bem-vestidos e de prontidão. $\mathrm{O}$ Circo Garcia contava com um picadeiro e um palco como espaços de apresentação. Em determinados momentos, o palco deslocava-se até o picadeiro, valorizando a apresentação e ao mesmo tempo aproximando o artista do público.

Os números circenses apresentados no espetáculo do Circo Garcia primaram pela elegância e por dificuldades técnicas das evoluções acrobáticas. Eram, no geral, números de grande impacto visual.

O espetáculo também revelou uma valorização do palhaço, pouco comum nos grandes circos. Geralmente, eles são postos no espe- 

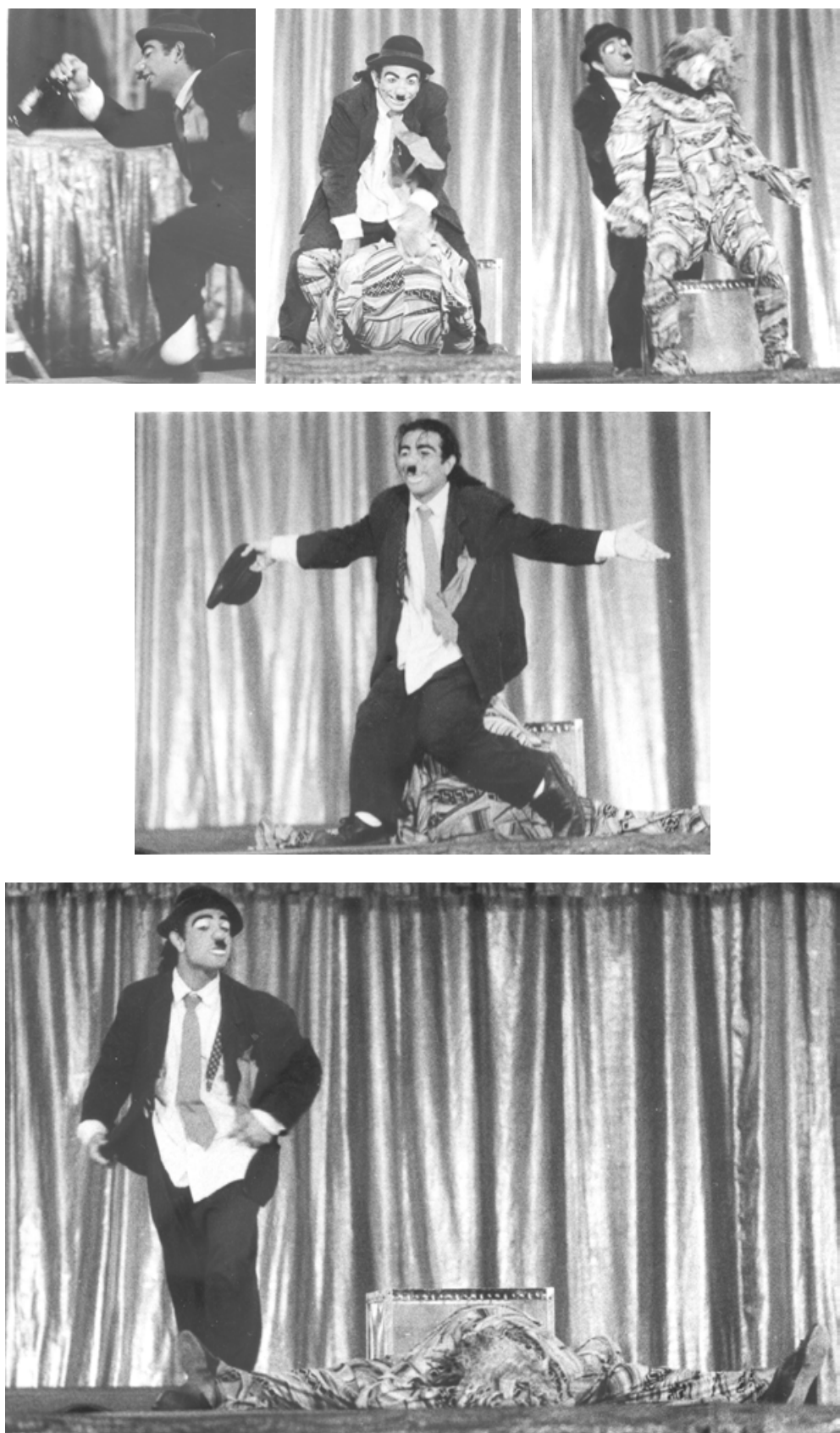
táculo com reprises cuja finalidade é preencher as lacunas enquanto se monta ou desmonta um grande aparelho. Não foi o caso do Garcia, cujo palhaço principal, o Kuxixo, teve papel de destaque, tanto valorizando o número de contorção, quanto com os outros palhaços.

\section{Kuxixo}

Kuxixo é de família circense, de terceira geração, por parte do pai, e de quarta, pelo lado da mãe. Nasceu e aprendeu a profissão no ambiente e com as necessidades do pequeno circo, o que quer dizer, voltado para o circo-teatro, para os dramas, comédias e esquetes. No Garcia, um circo que se dedicava às atrações circenses, ele desenvolveu todo o seu aprendizado teatral e recebeu da direção do espetáculo o devido apoio para a sua performance.

A personagem foi inspirada, de um lado, na experiência do circo-teatro e, de outro, em Charlie Chaplin. A influência de Carlitos era visível no terno preto, com suspensórios, sobre uma camisa branca, com gravata. A maquiagem era extremamente sutil e apresenta-

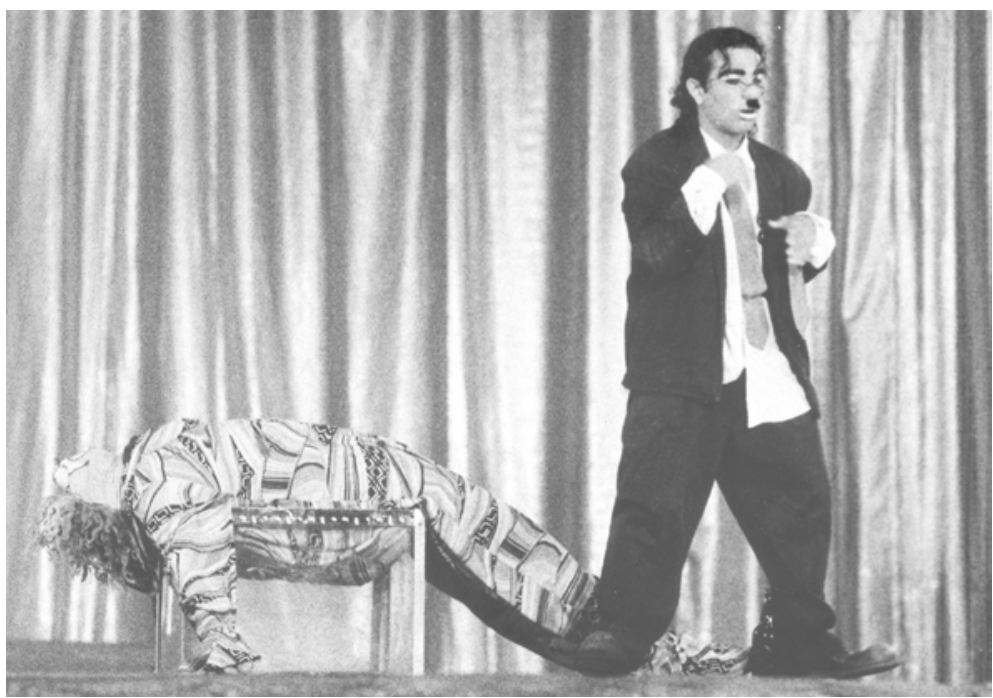




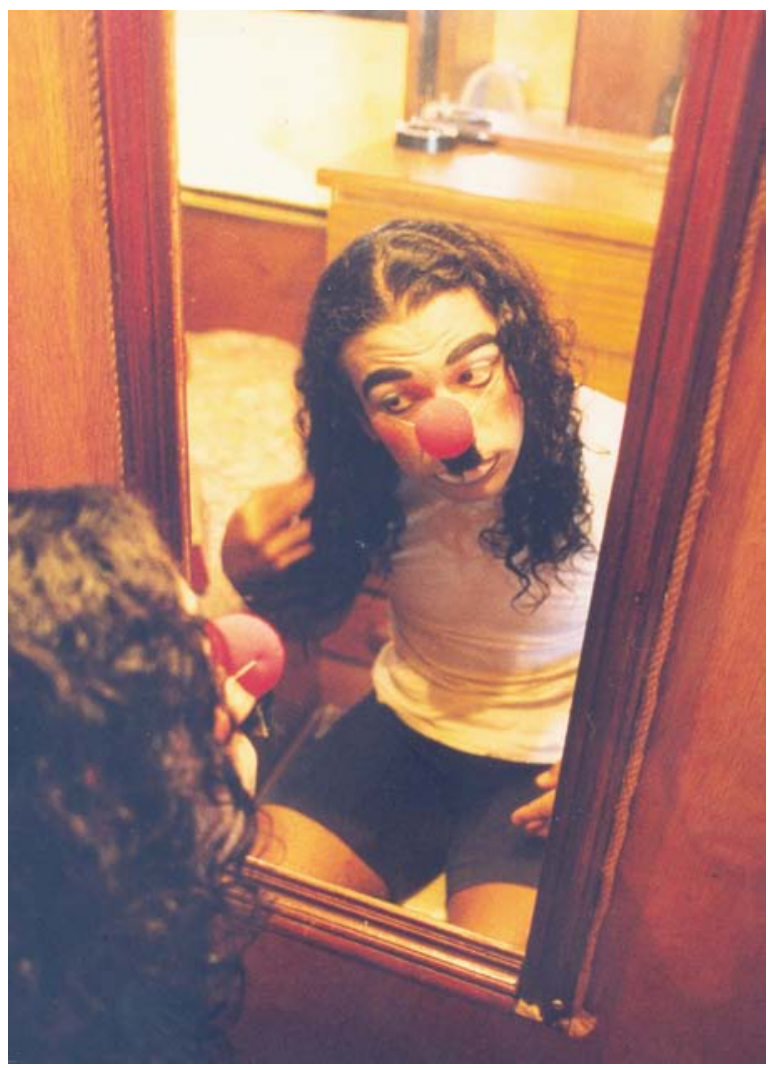

va uma síntese entre o Augusto (visível, por exemplo, no nariz vermelho) e o ator e diretor do cinema mudo, ao adotar um pequeno bigode e um chapéu-coco. A inspiração chapliniana evidenciava-se no modo de interpretar. No primeiro momento, com o número de contorcionismo, Kuxixo interpretou um bêbado e esteve o tempo todo imbuído de seu papel. Depois, contracenando com o palhaço Rói-Rói (Francisco Espinoza Saltos), interpretou um vagabundo que perambulava ao redor da cena, provocando um diálogo entre estilos distintos de interpretação. A disputa indicava a derrota de Kuxixo. Com o decorrer da entrada, no entanto, uma flor entregue por uma garota da plateia reanimou a personagem. A partir daí, com a flor 

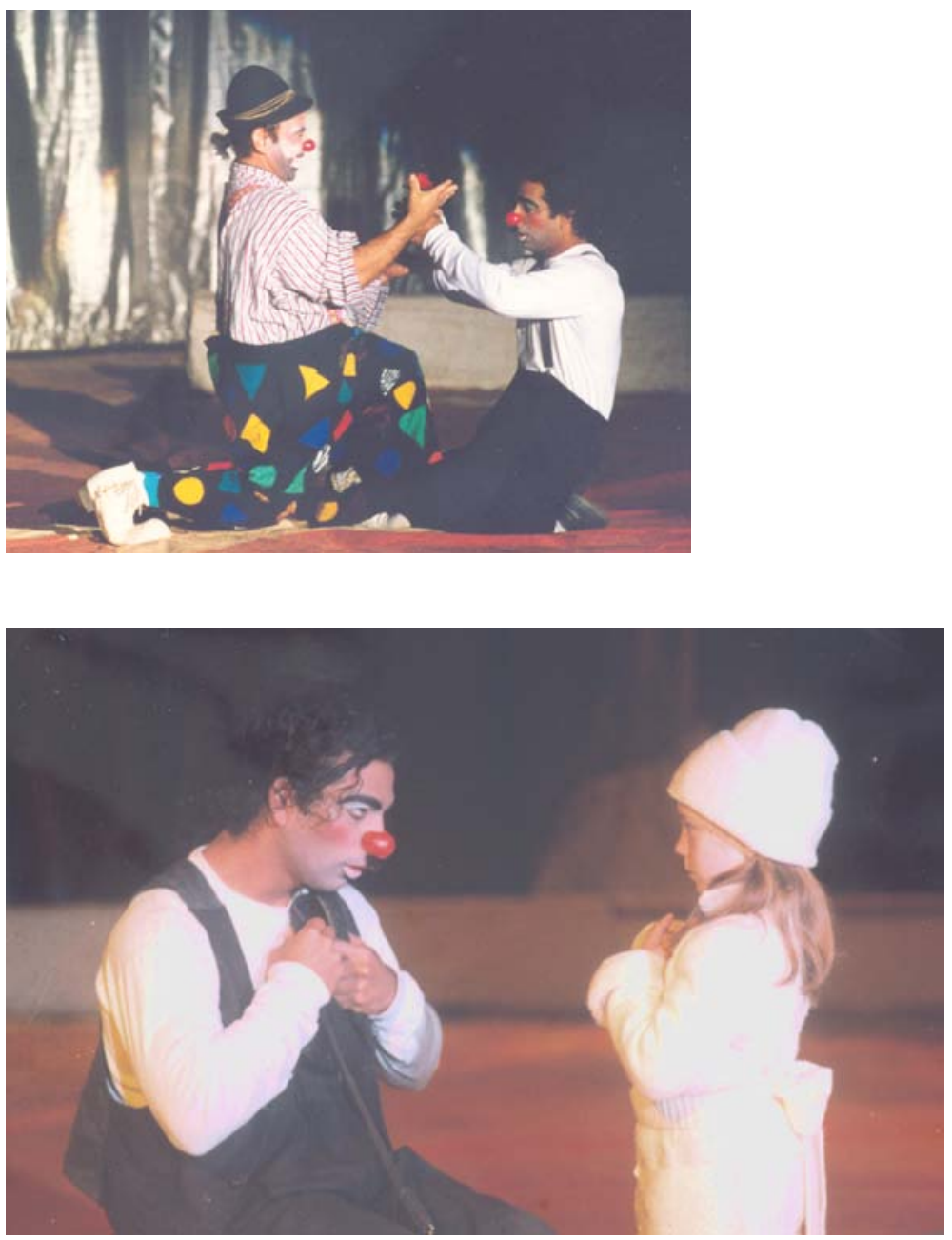

em mãos, procurou seu adversário, propondo-lhe a paz. Ela foi aceita, pondo fim à disputa entre tipos distintos de comicidade.

O gestual minucioso de Kuxixo contrapunha-se aos gestos largos de Rói-Rói. A mímica prevaleceu em toda a interpretação, e os detalhes gestuais foram valorizados. A disputa entre os cômicos foi proposta e desenvolvida a partir da gestualidade. 


\section{Entrevista}

Eu era de circo-teatro. Então, o meu negócio era mais voltado pro teatro mesmo, comédia, dramas, esquete cômica. O circo-teatro é mais baseado em cima da arte de representar. Já esse circo que eu tô trabalhando agora, não, ele é circo de variedades, ele é mais em cima de acrobacias, trapézio, malabarismo...

O palhaço, ele não é um personagem, ele é uma pessoa normal. Cada um de nós tem um palhaço dentro, cabe a você desenvolver ele. Como eu já disse, eu era de circo-teatro. Tinha uma peça, um drama, se chamava "Rosas para Nossa Senhora". Nessa peça tinha um moleque. E quem fazia esse moleque era meu avô, quer dizer, não era bem o meu avô, mas chamava ele de vô, porque o meu vô já era falecido, então como ele conheceu a minha mãe quando criança, minha mãe se criou no circo desse senhor. É o palhaço Pirulito, é Antonio

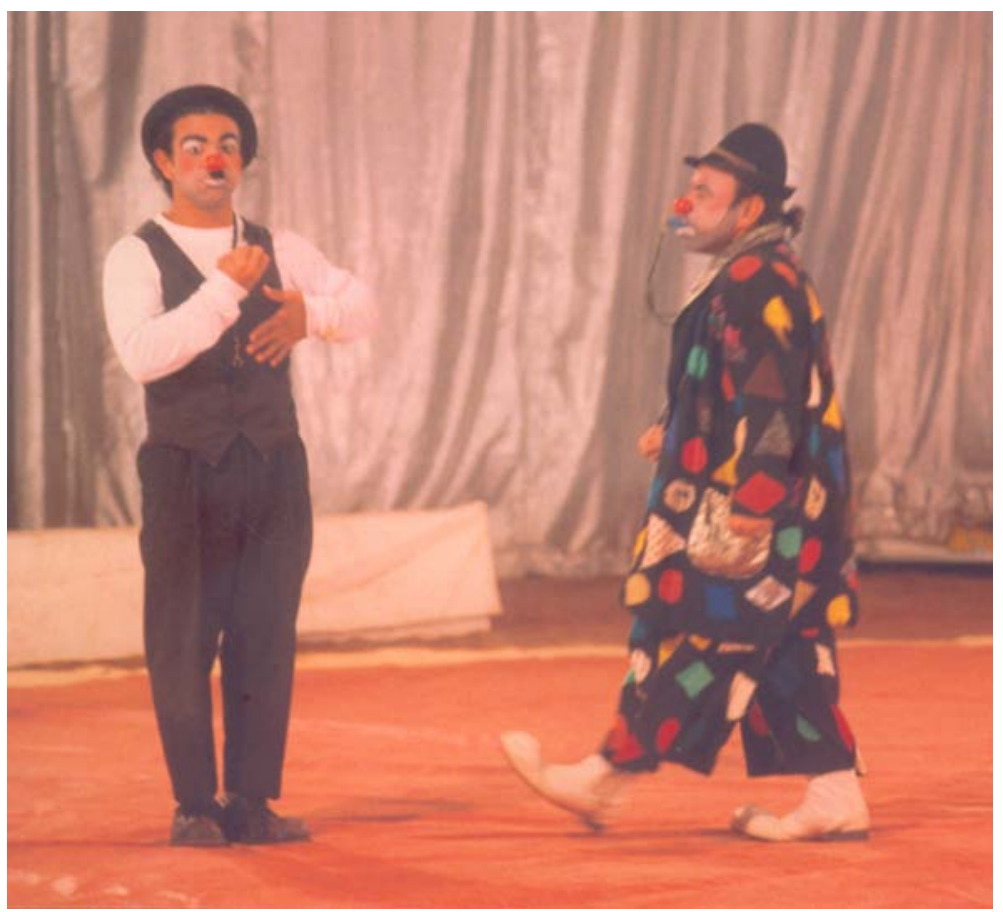




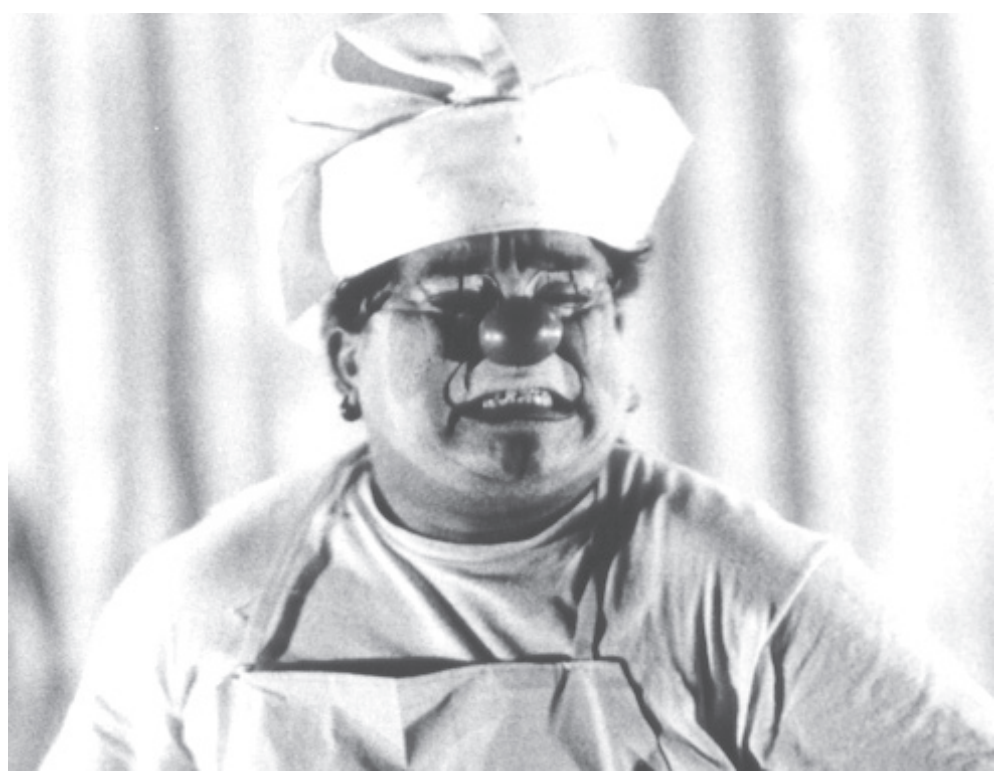

Malhione. Ele fazia um garoto de fazenda, que tomava conta de um burro e esse burro que chamava Kuxixo. Mas era fictício esse burro, entendeu, ele nunca aparecia. Ele entrava com uma peruca, o cabelo da peruca era todinho em pé, todo arrepiado. Quando eu nasci, que minha mãe me viu pela primeira vez, quando ela bateu o olho em mim, eu tinha o cabelo igual à peruca do meu vô Pirulito. Então, quando ela viu o meu cabelo em pé, ela olhou pra mim e falou: Ô Kuxixo! Então, eu tive o apelido primeiro que o nome. Toni de Soirée é o palhaço que tem que saber um pouquinho de tudo, entendeu? Então, vamos dizer assim, chega um trapezista, faz um número de trapézio, hora que ele sai eu tenho que entrar e fazer o que ele faz, embora tenha dificuldade, eu tenho que passar pra plateia que é fácil. Eu tenho que saber um pouquinho de cada coisa e essa já é uma tradição da minha família. Os artistas de circo-teatro eram mais completos, tinham que cantar, dançar, sapatear, tinham que ser acrobatas, trapezistas, saltadores, e tinham que atuar, por serem de circo-teatro.

Eu tenho muita sorte de ser de circo-teatro. Tem muita coisa que eu não vi, que a minha mãe lembra. Ela me fala alguma coisa. Aí, em 
cima disso eu faço alguma criação. Dou uma modelada pra mim, pro meu estilo de trabalhar.

Um dos setores que tá dando mais retorno é o de palhaço. Houve uma época - que eu não sei por quê - os palhaços que estavam aparecendo não eram... não que não fossem bons, mas tava havendo uma falta de, vamos dizer assim, de criatividade, espontaneidade, alguma coisa assim. Então, teve um longo tempo que, até mesmo os donos de circo, começaram dar preferência pra outras coisas, como trapézio, feras, entendeu? Aí, de repente, começou uma safra nova, começaram a aparecer palhaços bons. Porque, vamos falar, a alma do circo é o palhaço, tem trapézio, tem tudo, mas se não tiver palhaço não é circo, entendeu? Essa nova geração está se dedicando a fazer graça não só pra criança. E o palhaço, ele tem a chance de fazer o público pensar, porque o palhaço é o único artista no circo que tem a oportunidade de passar uma mensagem, entendeu? O cara que vai fazer um trapézio, ele vai fazer uma exibição de trapézio, o malabarista vai fazer uma exibição de malabarismo, ele não pode passar uma mensagem, uma história, alguma coisa. O palhaço, ele já pode, então pensando um pouquinho, com um pouquinho de criatividade, você consegue passar uma mensagem, ou então uma ideia, alguma coisa de bom pra quem tá assistindo. E aí você não vai atingir só a criança, vai atingir a criança e os adultos.

O circo é a forma de expressão mais antiga que existe. Ele consegue fazer até uma criança de rua, que é triste por causa das marcas da violência, uma criança de rua consegue sorrir. Então, vamos prestigiar qualquer circo, todo tamanho, se ele é pequeno, médio ou grande, o estilo de espetáculo, tanto faz, negócio é prestigiar. O Brasil, agora, parece que tá dando um incentivo pra cultura. Então, vamos; vamos todo mundo pro circo, que até mesmo pra quem é de circo - que o artista brasileiro, ele mesmo não sabe muito bem das suas raízes, não sabe como surgiu o circo, como surgiu o palhaço. Só você sabendo a sua origem, que você vai ter orgulho do que você é. 



\section{7 \\ Circo Xangal}

\section{O espetáculo}

Primeira parte: Arame alto; Equilíbrio; Tiririca em "O padre e as compras"; Facas, com participação do Tiririca; Cães; Tiririca em "Poroite"; Magia; Double trapézio.

Segunda parte: Jegue e búfalo, para montaria da plateia.

Terceira parte: Tourada.

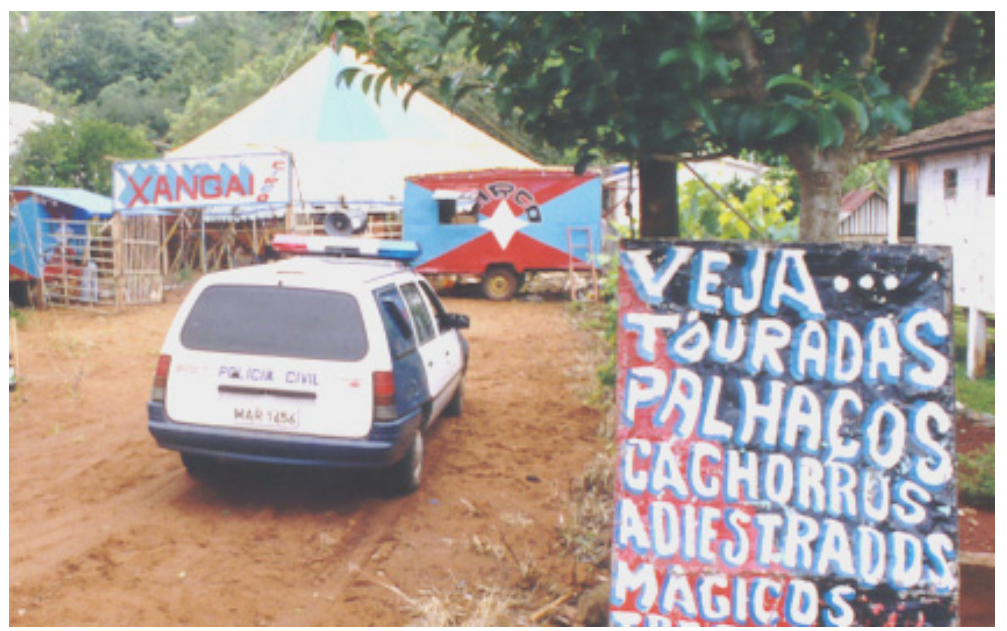



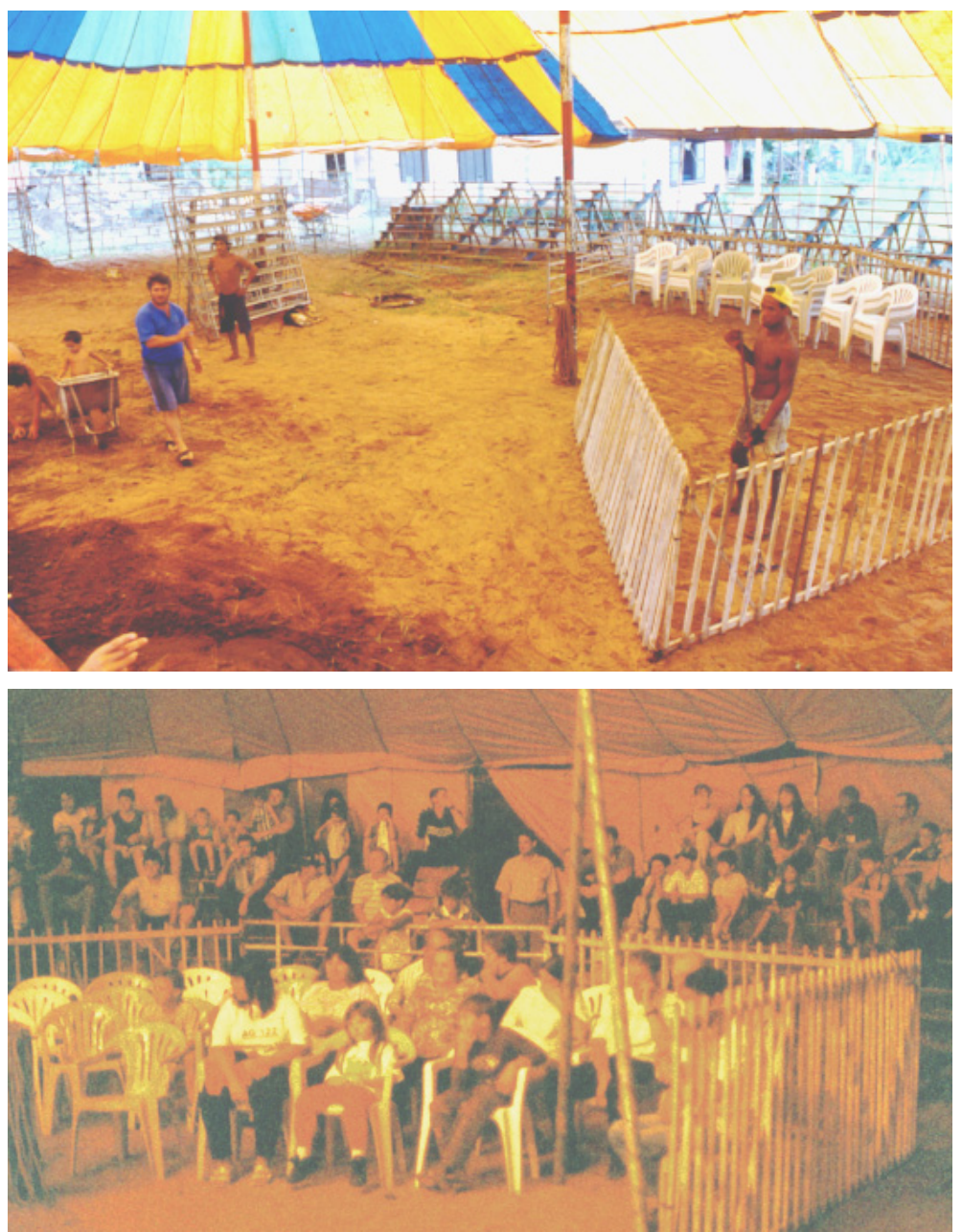

O Circo Xangai, visitado em Quilombo-SC, em 28 de janeiro de 1999, era pequeno e com a lona bastante surrada, com vários remendos, de cores ao sabor dos retalhos disponíveis. A precariedade do circo se fazia presente desde a entrada. A placa anunciando o espetáculo, rudimentarmente escrita, continha palavras que oscilavam entre o português e o espanhol. Era uma casa de espetáculos que se dedicava às touradas, variando os animais a cada noite. Os animais eram emprestados de criadores da localidade, que tinham seus no- 


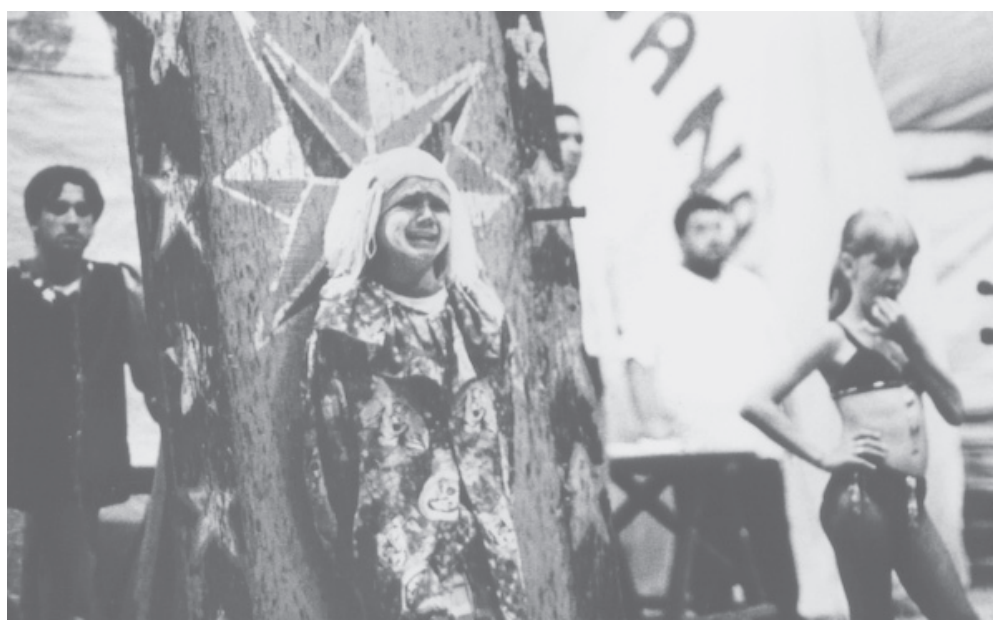

mes veiculados durante o espetáculo. A precariedade material externa também tinha seu equivalente no interior do circo, que contava com poucas cadeiras plásticas e uma arquibancada. Os recursos de iluminação eram reduzidos.

Para a abertura do espetáculo, uma gravação dava as boas-vindas ao público, permeada de mensagens do tipo: "enquanto houver uma criança no mundo, o circo não morrerá”. Uma pequena e surrada cortina trazia os seguintes dizeres: "Circo e cultura diga não as drogas", assim mesmo, sem acento no "e" e sem pontuação. O picadeiro não tinha a demarcação de tapetes. Os artistas trabalhavam sobre a serragem.

\section{Tiririca}

Tiririca vestia uma calça xadrez, não muito larga, com predomínio do vermelho. Um camisolão estampado, de cores que não apresentam contraste com a calça, completava o vestuário. Ele usava uma peruca, de meia feminina, com fios longos e brancos. Como bengala, ele carregava um pedaço de pau, tortuoso como um parafuso, também branco. 
A performance do Tiririca não trazia muita improvisação. $\mathrm{Na}$ apresentação assistida, em sua primeira participação, Tiririca encenou "O padre e as compras", baseada exclusivamente em piadas. $\mathrm{O}$ riso advinha do jogo associativo entre palavras e situações aludidas. No caso em questão, a graça firmava-se a partir do jogo rápido, que induzia à seguinte situação: na correria, ao invés de levar aos fiéis, na missa, a Bíblia, Tiririca, um suposto ajudante do padre, carregava o livro de compras da paróquia, que passou a ler. Mecanicamente, sem se dar conta do ocorrido, o padre conduziu um "Ora pro nobis", induzindo os fiéis nas respostas conhecidas da reza.

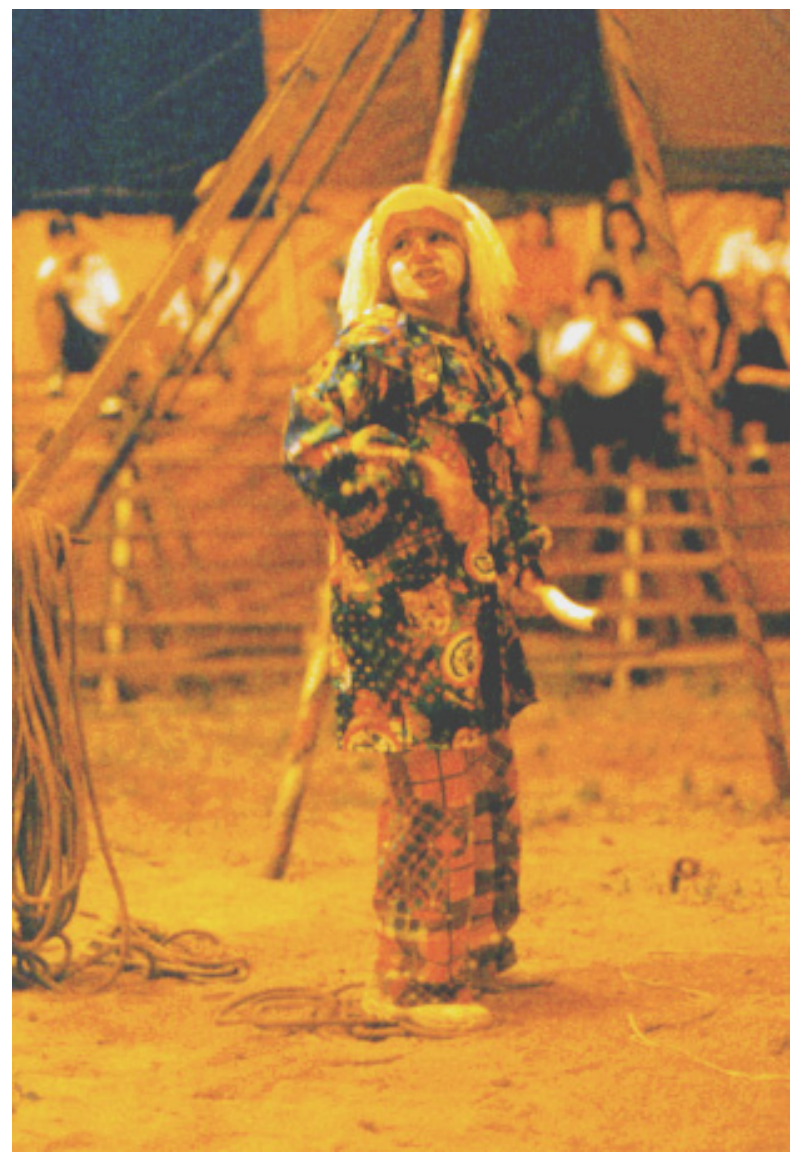




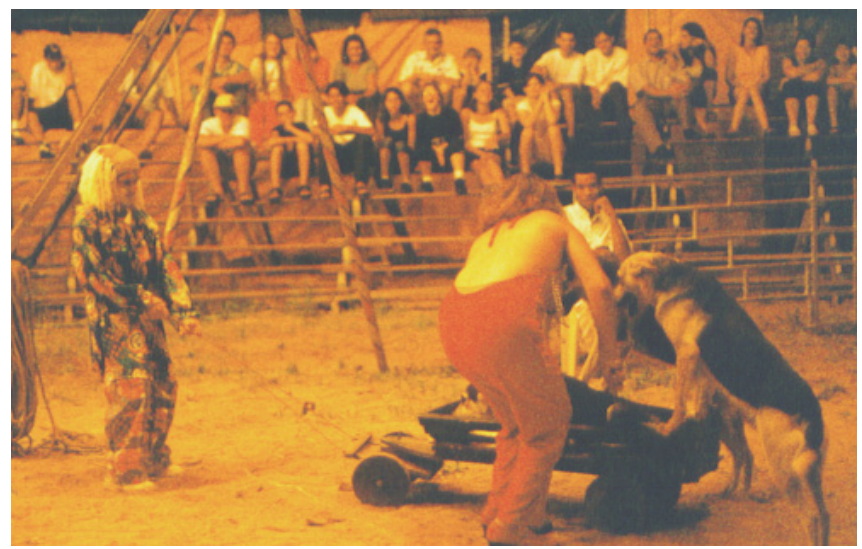

A segunda participação do palhaço deu-se no número de adagas, explorando o temor de ser atingido. Depois, Tiririca retornou à cena com a reprise do "Poroite".

Quanto à exploração de fatos, coisas e costumes locais, Tiririca fez pouco uso desse recurso: na primeira participação, uma pequena referência à carne assada e vinho, um costume alimentar local; na participação do número de facas, ele associou o sangue ao chouriço, também comum no Sul.

Henrique Graziani, na época, um garoto de 11 anos, criou o Tiririca, do Xangai. Ele nasceu no circo e iniciou na arte do palhaço com 3 anos de idade. Impressionou o vigor e brilho dos olhos do artista, que falava do circo e da profissão com entusiasmo, sempre se apoiando no conhecimento e no constante relacionamento com o pai e o avô. Tudo foi herdado deles: nome, maquiagem, estilo da roupa, modo de interpretação etc.

O aprendizado mesclou-se com aquilo que captou com a família, mais a observação e imitação de outros palhaços. Tiririca tinha consciência de que seu papel no picadeiro era o de um animador. Assim, tentava imprimir este ritmo nas entradas e reprises, nas participações em outros números, como no caso das adagas ou mesmo da tourada. Mas, acima de tudo, encarava a profissão como um destino inevitável, associado à consciência de que deveria estudar "para ser alguém na vida”. 


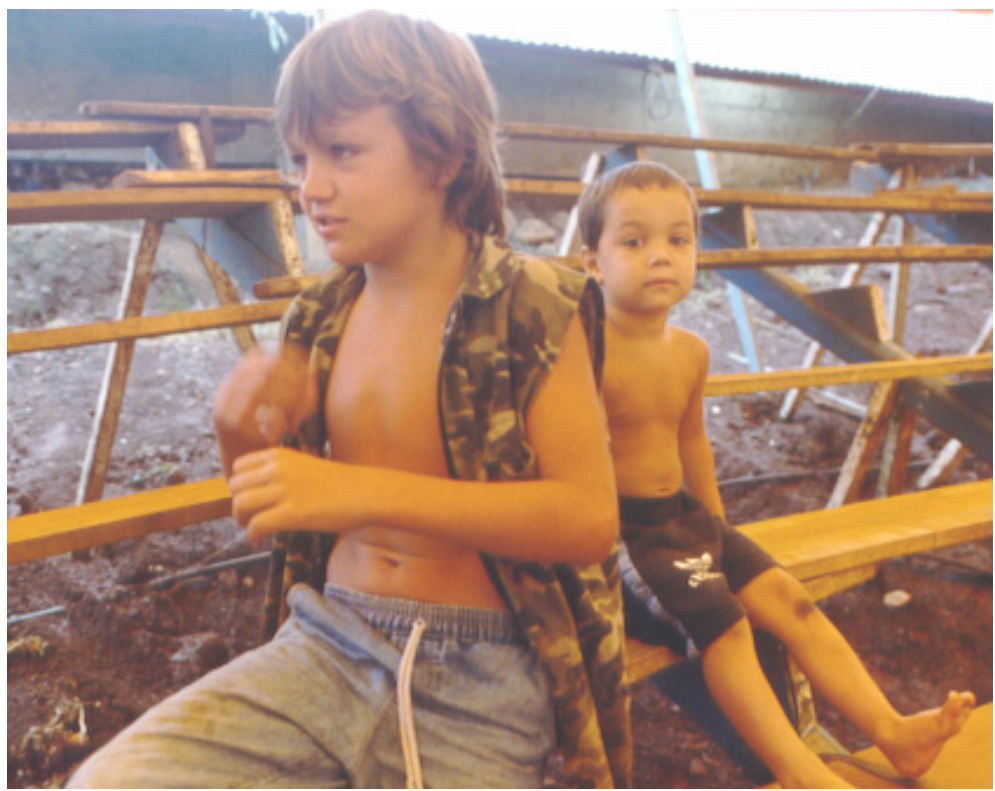

\section{Entrevista}

Gosto muito de palhaço, tudo, na mais perfeita diversão.

Gosto mais da noite [referindo-se ao espetáculo noturno] é mais maior, mais tempo, mais variedade; gosto por causa das touradas também.

O que meu pai não ensina, eu procuro ver pra eu aprender mais.

[Sobre a maquiagem] É branco do lado, branco do outro, essa maior que essa, aí faz o queixo vermelho e a lágrima e o bigode.

\section{Você vai na escola?}

Vou, toda cidade.

\section{Em que classe você está?}

Quinta série. Passo agora.

\section{Você gosta de escola?}

Gosto. Não é tanto, tanto, mas passa. Estudo. Precisa, porque palhaço vai ser meu futuro e preciso saber ler e escrever. Gosto, não troco a profissão por nada. 
[Sobre A bomba] Chegam dois palhaços lendo jornal, ou brincando. Se pega um no outro. Cai e um desmaia. Aí, vai lá coloca a bomba na boca. Bomba de encher, e enche ele. Daí vai saindo de novo. No que vai saindo, desmaia de novo. Ah 'tá furada, tem que tampar os buracos deles'. Tampa a orelha, tampa o nariz, tampa a boca. Enche de novo e sai andando: 'ah, tem mais um furo'. Aí ele pega o jornal, enrola o jornal - é uma banana. Aí ele vai atrás do palhaço, coloca a mão na mangueira, coloca a banana na boca e sai correndo. 



\section{8 \\ CIRCO DI MONZA - \\ Teatro Biriba/Geraldo}

O Circo di Monza foi visitado em 31 de janeiro de 1999, na cidade de Redentora-RS. Era um circo de porte médio, cujo espaço de cena era composto por um amplo palco. O público acomodava-se em arquibancadas e cadeiras.

Biribinha (Geraldo Santos Passos) era o proprietário e palhaço da companhia. Sua família sempre se dedicou ao teatro de pavilhão e, posteriormente, ao teatro sob a lona. Ele abandonou, temporaria-

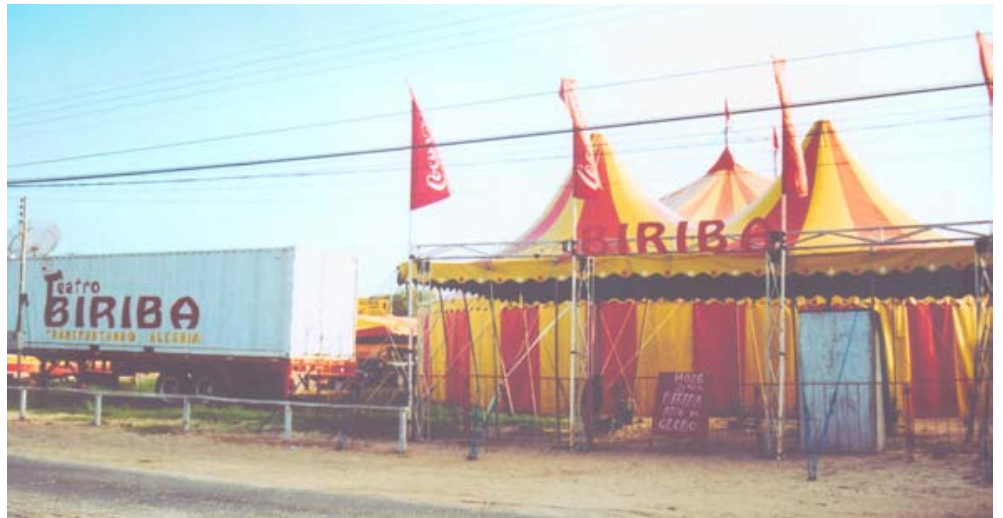




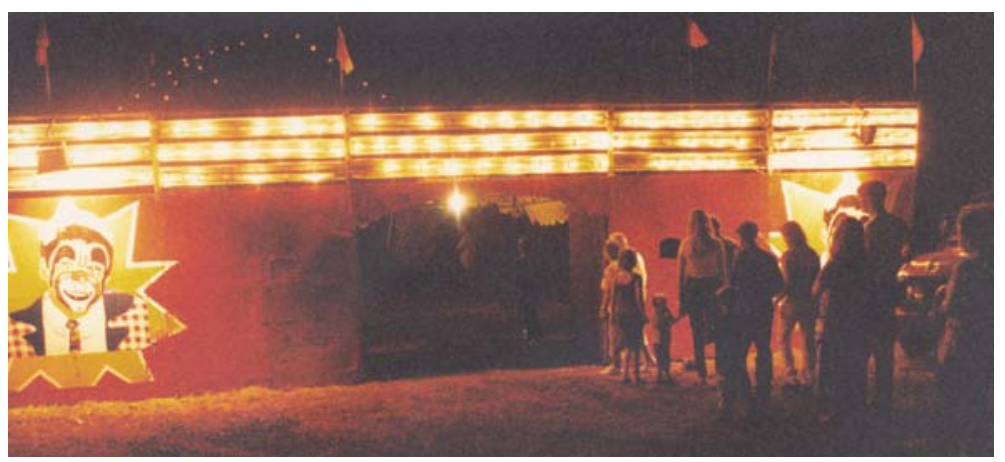

mente, o circo-teatro e dedicou-se ao espetáculo de variedades. $\mathrm{O}$ espetáculo tinha um tratamento visual apurado. A indumentária dos artistas apresentava malhas em tons claros e muito brilho.

Algum tempo depois, em 10 de fevereiro de 2004, em Balneário Arroio do Silva-SC, Geraldo Santos Passos dedicava-se à atividade teatral sob a lona, com o Teatro Biriba. Abandonou o nome de Biribinha e adotou o de Biriba, seguindo a linhagem de seu pai.

\section{Circo di Monza - O espetáculo}

Primeira parte: Lira; Batatinha; Pirofagia; Biribinha em "Morrer pra ganhar dinheiro"; Malabares, Adagas; Biribinha em "A natureza”; Magia.

Segunda parte: Dança; Monociclo; Biribinha em "Pensão da dona Estela".

\section{Teatro Biriba - O espetáculo}

Primeira parte: Drama: "É sublime perdoar".

Segunda parte: Esquete: Luiz Pinto. 


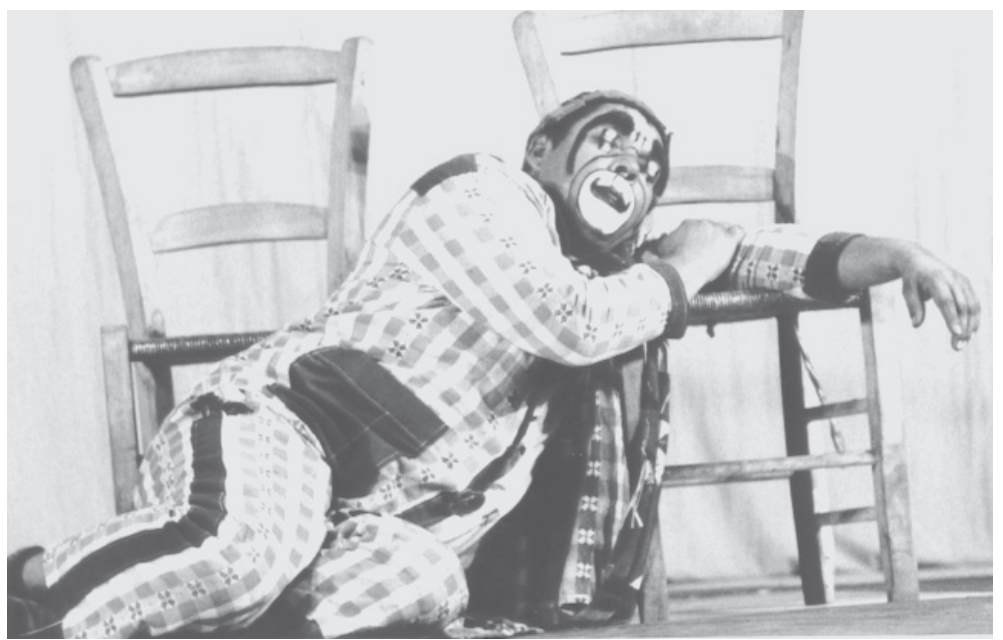

\section{Biriba}

Biriba é um artista preocupado com sua profissão. Seu desempenho cênico é fortemente marcado pela vivência teatral, embora tenha trabalhado também em grandes circos, na função de Toni.

A entrevista realizada foi das mais interessantes. Nela, foram exploradas as diferenças entre palhaços de "picadeiro" e de "palco", de acordo com as expressões do artista. Elas diferenciam o palhaço de reprises, dos grandes circos, em que a linguagem falada é reduzida ao mínimo indispensável e as cenas se sustentam em maquinários, aparelhos e adereços, aliados ao gestual, e os palhaços dos pequenos e médios circos, que dão ênfase às entradas faladas, com roteiros com diálogos preestabelecidos, gags, piadas e cacos, além, evidentemente, das expressões corporal e facial, peculiares a cada artista. Biriba falou também sobre a diferença entre os espetáculos do circo-teatro e o de atrações circenses; sobre o fracasso atual dos dramas e a preferência pelas comédias; sobre o processo de aprendizagem; a experimentação de piadas novas; a relatividade do roteiro dos esquetes; a composição do palhaço etc. Biriba é bastante consciente daquilo que faz. Ao contrário de muitos, não tem respostas 

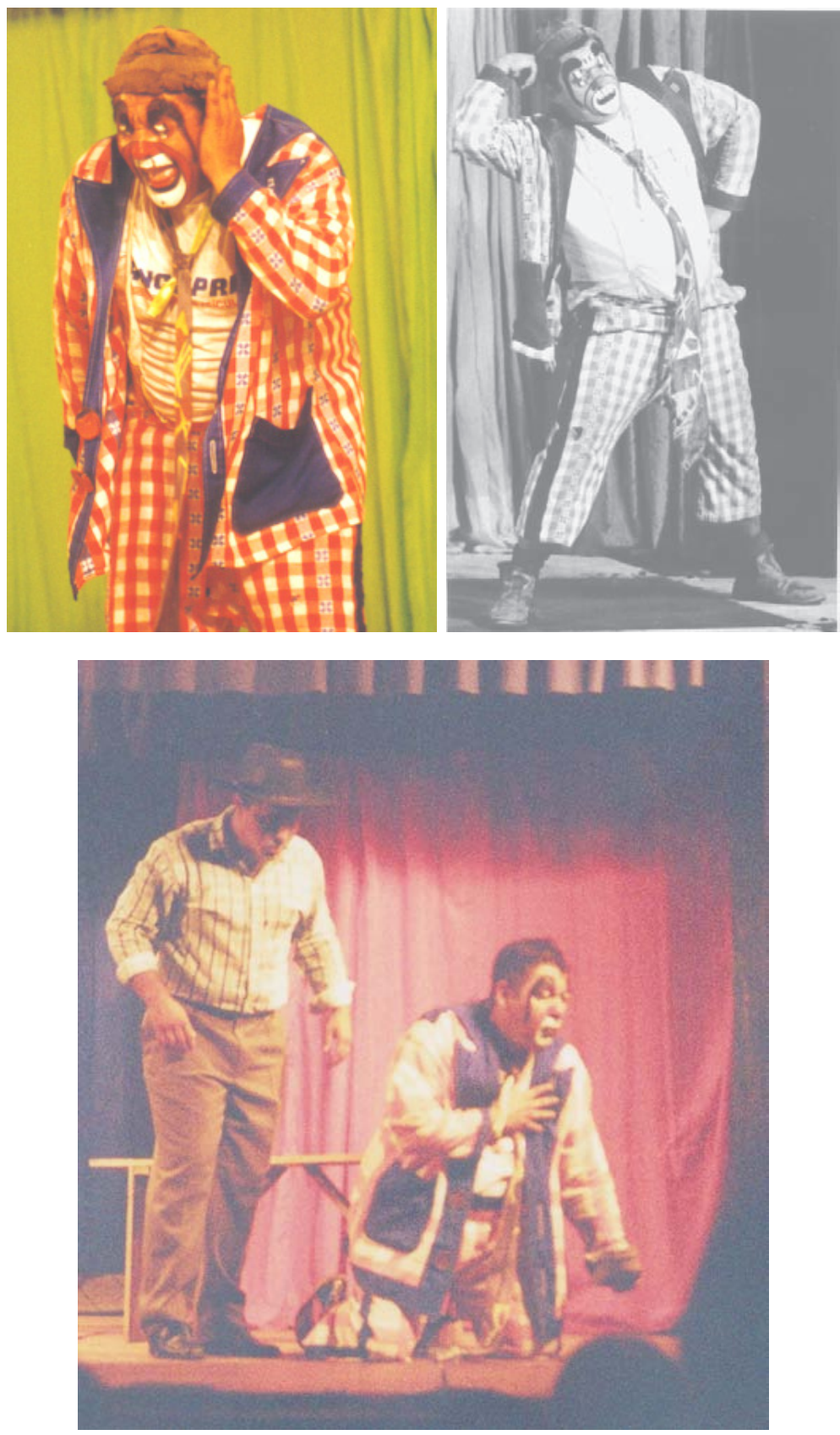
prontas e intuitivas sobre a profissão, tais como: "a gente nasce palhaço", "sempre foi assim" etc.

O espetáculo foi visto duas vezes. Segunda-feira à noite, $1^{\circ}$ de fevereiro de 1999, o Circo di Monza ofereceu seu último espetáculo, em Redentora-RS.

O último espetáculo dos circos nas cidades (ou "praças", como dizem) não é completo. Quando o circo tem aparelhos grandes, como Globo da Morte, ou Trapézio Voador, Pêndulo etc., geralmente esses aparelhos já estão desmontados. O espetáculo é levado com muitos cortes.

No caso do Circo di Monza não houve cortes. Ao contrário, alguns números que não foram apresentados no domingo, desta feita o foram, como Trapézio em Balanço, Corda indiana, Rola-rola e Arame alto, em substituição a outros.

No segundo espetáculo do Circo di Monza, Biriba entrou quatro vezes em cena. Na primeira, ele apresentou o esquete do Armazém; na segunda, uma cena mímica de um datilógrafo, com perfeita sincronia entre expressão corporal e a sonoplastia; na terceira, o esquete "Tirar leite da vaca"; por último, sob fundo musical de Luzes da Ribalta, apresentou um texto poético que trata do palhaço, de sua

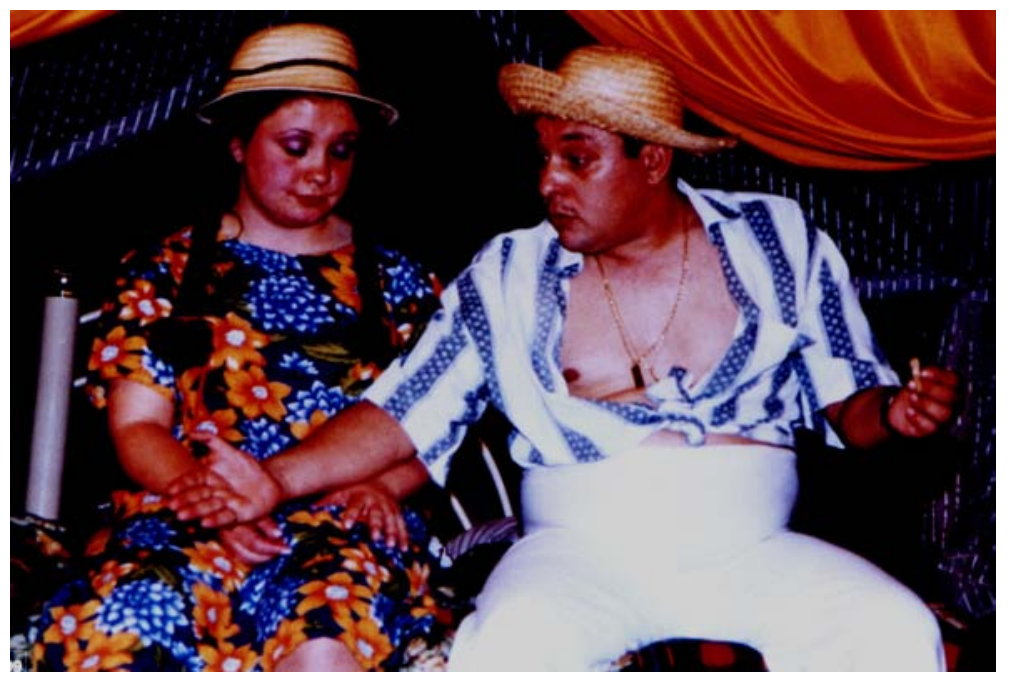



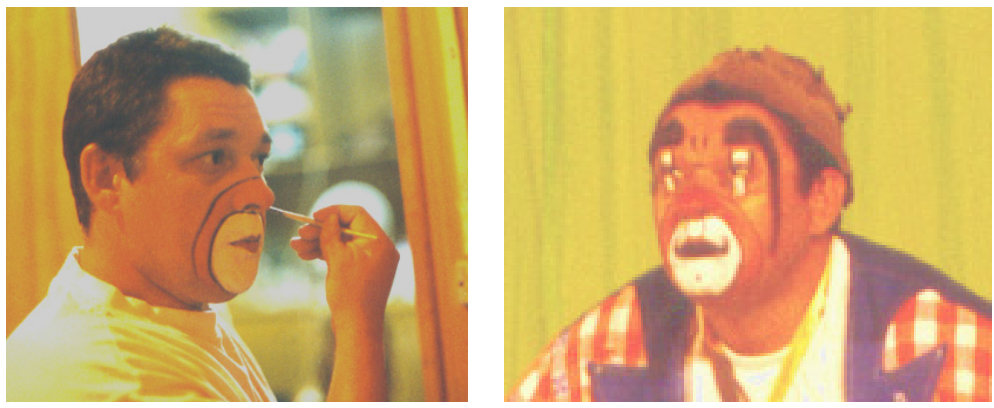

função e seus desesperos. Ao final, chamou todos os artistas da companhia ao picadeiro, para as despedidas da cidade. O público, apesar de pequeno, emocionou-se bastante e aplaudiu em pé. O carisma do palhaço Biriba era notável.

Em Redentora, o circo não foi bem financeiramente. Conversamos sobre isso com o Geraldo Passos. Ele atribuiu a ausência de público à crise econômica, ao mês de janeiro (férias), à data, pois era final de mês. De resto, todos os circos têm tido pouca plateia. Os problemas com prefeituras e polícias civil e militar são imprevisíveis. Cada lugar estabelece critérios próprios para autorizar a entrada de circo no município. Alguns chegam a fazer um levantamento do circo, de sua aparência e de seus antecedentes, para conceder, ou negar, a entrada. Em outras localidades, exige-se xerox da documentação pessoal de todos os integrantes da companhia, coibindo flagrantemente a liberdade de ir e vir. Em suma, não há uma legislação específica sobre o assunto e tudo fica a critério da simpatia ou antipatia das autoridades municipais. Evidentemente, esse problema coloca-se para os pequenos circos.

Anos depois, Biriba e seu Teatro foram encontrados encenando dramas, comédias e esquetes. No dia visitado (10-2-04), ele encenou o drama "É sublime perdoar", seguido de um esquete cômico, "Luiz Pinto". 


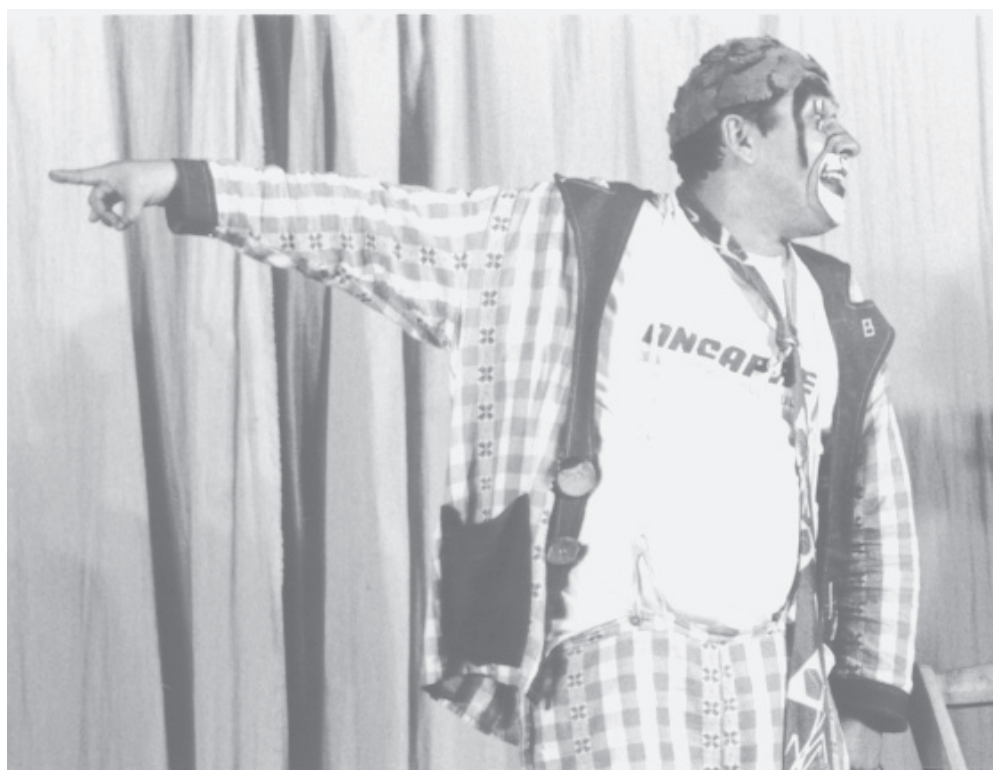

\section{Entrevista}

Certa vez, meu pai chegou para mim e falou: "Você vai começar a fazer palhaço". Nós estávamos lá em Santa Catarina e numa praça o palhaço saiu. Ele falou para mim: "Taí tua chance". Entrei... foi tão frustrante a minha primeira entrada de palhaço. Criança nenhuma deu risada. Passado um tempo, eu fui para outra cia., onde eu comecei a fazer palhaço pra adulto. Passado mais uns dois anos, nós estávamos em Xanxerê. Deu a doença nele [o pai], o derrame. Tive que assumir, da noite pro dia, e fazer o papel de Biriba.

Essa maquiagem é do pai, o pai tinha feito e eu, quando eu comecei a fazer palhaço, eu fui pra frente do espelho e falava: "Meu Deus, como é que eu vou fazer minha maquiagem?”. Meu pai fazia a sobrancelha bem certa. Eu não... queria puxar o preto na sobrancelha, aqui mais largo, os contornos, a boca diferente também. Nessa pintura, eu me senti bem. 
Quando foi pra mim fazer mesmo o palhaço, eu fiquei meia hora pra mais na frente do espelho. Fazia uma coisa, não dava certo. Eu cheguei a me apaixonar por mim mesmo. Eu gostei, o povo vai gostar também, eu tenho que me amar, eu tenho que me conquistar. Então, daí modifiquei voz também. Comecei com a minha voz própria, depois comecei a afinar.

O nosso público é a criança, a criança leva o pai. No teatro a criança vem, gosta. Mas o alvo principal é o adulto. Tem que tirar ele de casa.

Estou acostumado com o palco e o nosso palco sempre era o sistema italiano.

Os outros palhaços por aí, eles apelam para os defeitos, ou a pessoa é careca ou é gorda. Então, eles querem tirar proveito em cima daquilo. É o cuidado que eu tenho. Eu jamais vou falar de uma pessoa da plateia de modo pejorativo. Eu sempre posso tirar uma palhinha dele, mas eu vou pedir alguma coisa pra ele, vou ouvir ele, mas jamais tocar no defeito dele.

Tem que ter suas restrições pra saber até onde ele pode pisar. Senão, em vez de ele se tornar engraçado, ele vai se tornar ridículo. Uma mulher, por exemplo, eu sempre me dirijo à mulher, pode ser

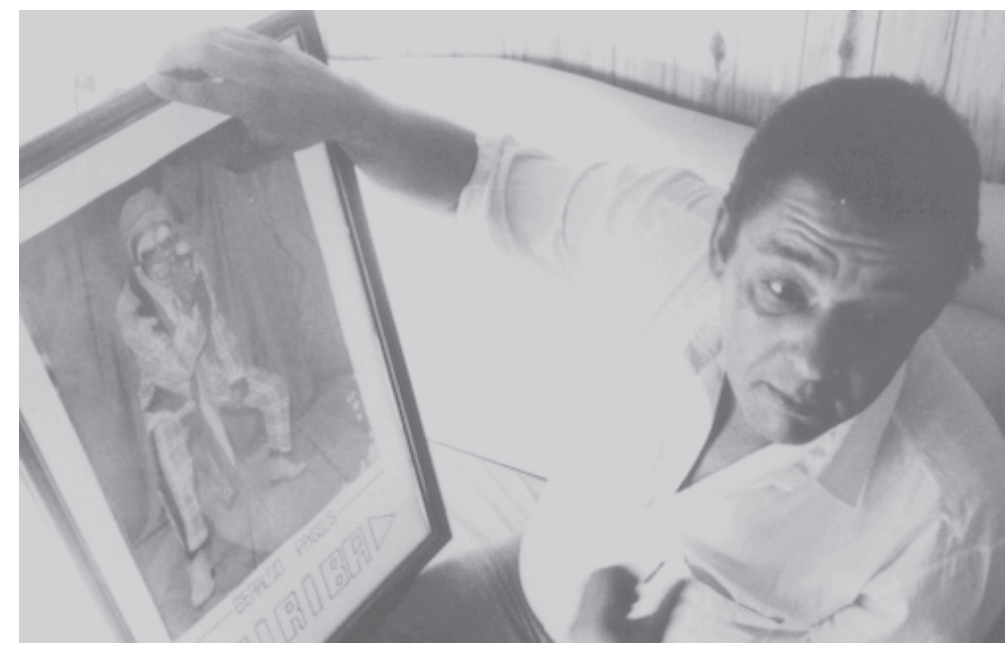


casada, solteira, eu sempre me dirijo com carinho. Tinha até uma senhora de 70 e poucos anos que falou: "Depois do meu marido, você foi meu único namorado”. Quer dizer, ela vinha ao espetáculo, eu mexia com ela, sabia que ela era viúva, eu chegava pra ela e dizia: "Coisinha fofa, meu tesouro". Trabalhando, mas nunca esquecendo dela.

Vaia, graças a Deus, eu nunca recebi. Não sei como eu me sentiria se recebesse uma vaia. Recebi crítica.

O drama... o pessoal diz: "É pra chorar, não vou”. Quer ir pra dar risada, pra esquecer. Então, o drama... a gente tem uma preparação enorme, tem dramas lindos, mas para enriquecer o teu ego. Só.

(...) Ele é bem despojado, fala bastante bobagem. Eu acho que meu personagem é bem alegre, tudo para ele é alegria.

Observando e experimentando. Eu acho uma coisa tão desagradável ali, em cima do palco, tu vai tentar terminar uma piada e teu escada larga uma outra em cima, procura te cortar o final da piada, o desfecho da piada. Espera... a plateia tava dando risada e você falou, ninguém escutou. Depois que passa o tempo não adianta falar mais, não dá mais risada.

Os textos são muito antigos. Então, a gente vai adaptando aqui, coloca uma piadinha aqui, outra ali... 



\section{9 \\ Circo Maravilha}

\section{O espetáculo}

Arame alto; Puxa-Puxa e Batatinha em "Poroite"; Magia; Lira; Puxa-Puxa e o Apresentador em "Cidade de trás pra frente"; Corda indiana; Bicicleta; Bonecos cômicos e Malabares.

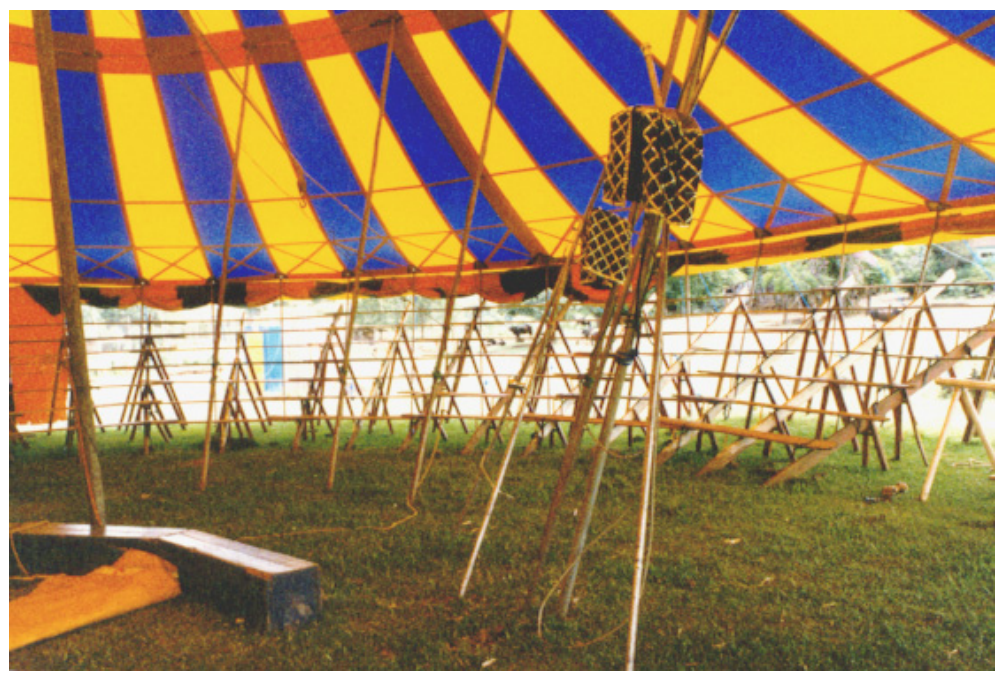




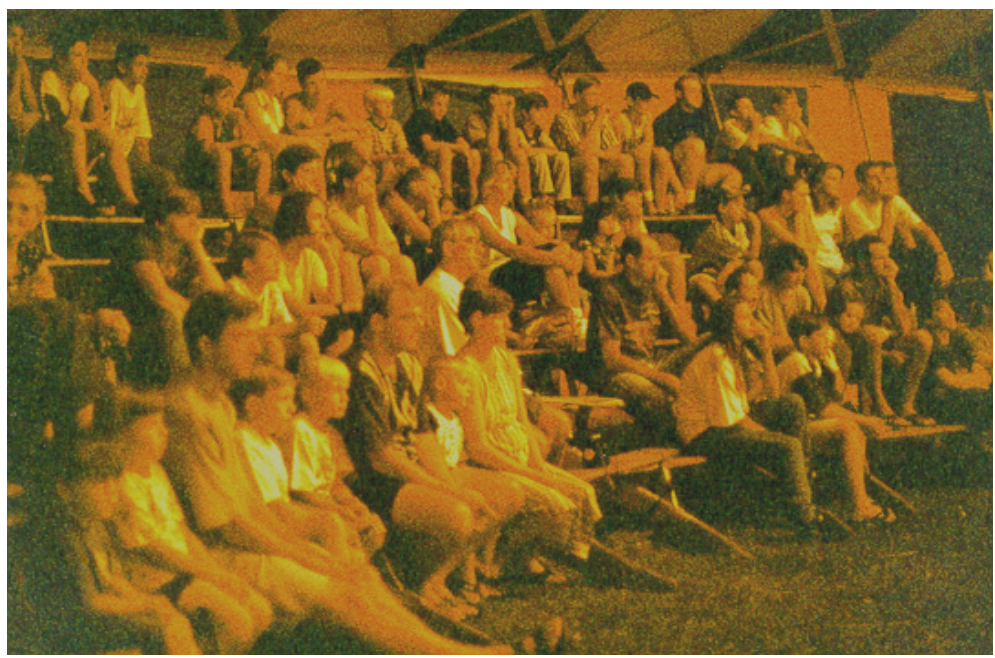

O Circo Maravilha foi visitado em 2 de fevereiro de 1999, na cidade de Boa Vista do Buricá-RS. No contato inicial, foi possível realizar a entrevista com o palhaço Puxa-Puxa e com sua parceira, Batatinha, uma garota que, na época, tinha 12 anos de idade, filha do proprietário do circo e apaixonada pela arte do palhaço. À noite, assistiu-se e fotografou-se o espetáculo, que foi o último da praça, portanto, com as características próprias da ocasião. Neste caso, o Globo da Morte já estava desmontado. O circo tinha estreia marcada para a sexta-feira seguinte, em Campo Novo-RS.

O Circo Maravilha era pequeno (18 metros x 24 metros) e muito bem-arrumado, aparentando uma cuidadosa organização. A área de atuação dos artistas concentrava-se em um picadeiro, devidamente demarcado por caixotes. O público acomodava-se em arquibancadas simples, de madeira. O espetáculo, apesar de singelo, acompanhava a organização do circo.

\section{Puxa-Puxa}

Puxa-Puxa teve duas participações no espetáculo. A primeira, com a Batatinha, no "Poroite". Na segunda, Batatinha não se apre- 


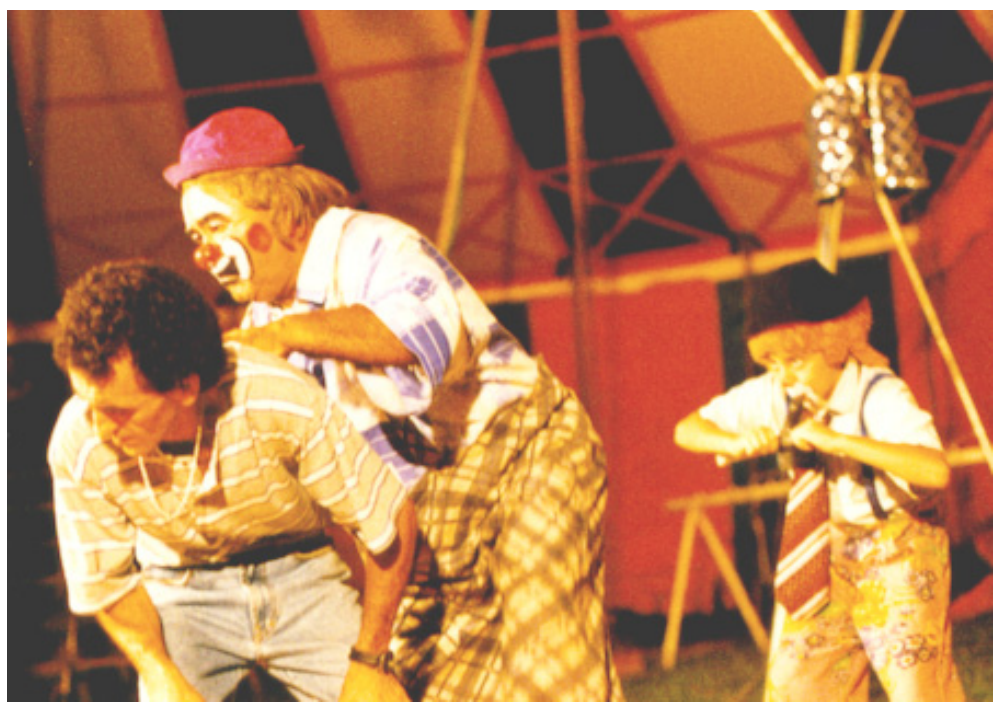

sentou, pois preparava-se para o seu número de malabares. PuxaPuxa levou a entrada "A cidade de trás pra frente", com a participação do Sr. Joel, proprietário do circo e apresentador do espetáculo.

Puxa-Puxa foi criado por Mario Esteves Martins, nascido em Catuípe, então distrito de Santo Ângelo-RS, em 12 de abril de 1944. Aos 18 anos, resolveu seguir o circo. Aprendeu a profissão de palhaço no circo-teatro. Embora tenha se afastado da profissão por dezesseis anos, e foi ser caminhoneiro, não pensava em abandonar mais o circo, mesmo com todas as dificuldades que enfrentava.

Puxa-Puxa era um palhaço discreto e de extrema expressividade, tanto corporal como facial. Ele não fazia uso de gestos obscenos, nem de palavrões. Sua interpretação era despojada, simples e precisa. Era o típico palhaço ingênuo, a quem todos enganam. O raciocínio era deveras lento, retardando em muito a compreensão daquilo que o parceiro em cena tentava lhe dizer. Sua maquiagem era alegre, com destaque para o largo sorriso.

Batatinha foi criada por Marcela de Queiroz. Na época, tinha 10 anos de idade. Ela desempenhou com eficácia sua parte de escada. A menina brilhou no picadeiro, tanto como palhaça como em seu malabares: irradiava alegria, otimismo e amor por sua profissão. 


\section{Entrevista}

Mario: Eu nem sabia o que eu ia fazer no circo. Eu entrei numa comédia e fui ficando por lá. Aí, depois eu comecei a fazer número de circo... fazia o vulcão. Eu fazia Crom, pra depois apresentar o espetáculo.

Minha família toda, quase toda, nasceu em circo. Eu tenho dez filhos e naquela época já tinha a televisão (risos). Quando eu tava parado, eu morava perto do trem e o barulho me acordava. Aí, então, são dez: seis gurias e quatro rapazes. Inclusive, as gurias, todas elas continuaram trabalhando em circo.

Eu trabalhava com outro nome. Um rapaz da Bahia me deu o nome de palhaço. Eu trabalhava com o nome de Gaiato. Depois, eu passei a trabalhar com o nome Puxa-Puxa. Faz mais de vinte anos.

Eu fazia escada. Um dia, o dono do circo, que era o palhaço, ficou doente. Aí, falaram pra mim: "Pinta a cara”! Aí eu perguntei: "Mas vai dar certo?" O circo lotado... eu pintei a cara, agradei e gostei. Isso foi em 68.

Eu acostumei a trabalhar com o meu patrão e ele não gostava de pimenta. Então, eu apreendi a fazer assim. Mas, se quiser, eu faço, eu apimento. Não precisa, não precisa agradar com pimenta. Se a gente levar as coisas certinhas, não precisa de pimenta.

Marcela: Comecei há quatro anos atrás... Circo Colombo. Eu falava: "Deixa eu entrar de palhaço, eu gosto tanto!". Aí um dia ele [Sr. Mario] falou: "Já que tu gosta de entrar de palhaço, então entra". Aí eu comecei a fazer o Batatinha.

Eu uso uma camiseta de manga curta, com botão na frente, e uso também uma calça de palhaço, larga, que era do meu pai, quando ele era palhaço.

Meus colegas, quando eu estudo, não sabem quem sou eu. Eu não falo. As professoras sempre falam: "No final da aula, a Marcela vai sentar numa cadeira e qualquer pessoa que quiser fazer uma pergunta faz". Só o personagem que eu não conto, porque eles começam a rir de mim. Os guri, principalmente, é muito gozador. Aí eles começam a me chamar de cabelo de aço, aí eu não falo. 


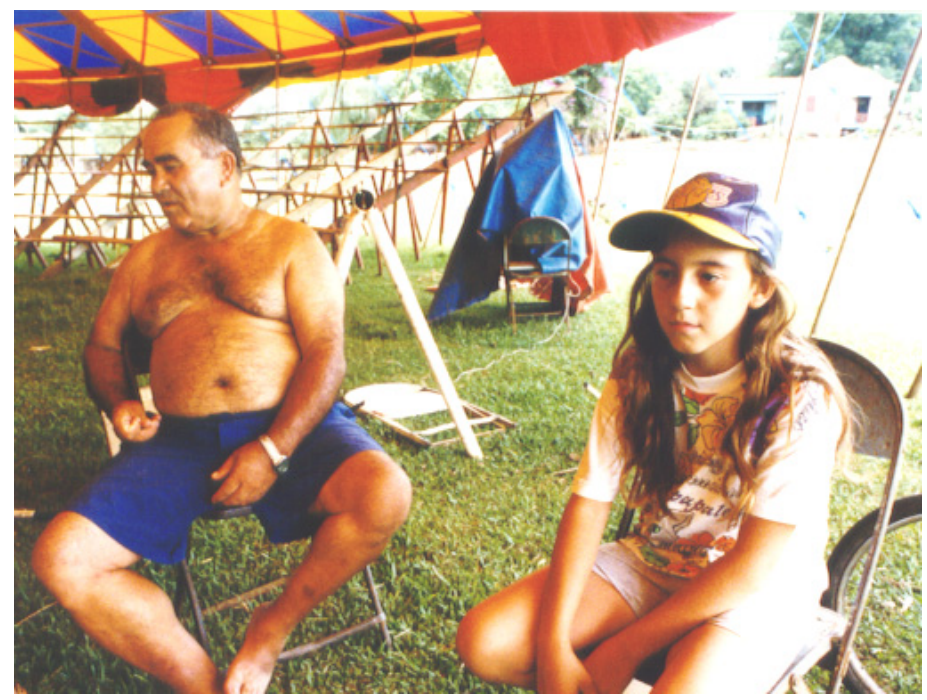

Mario: A gente trabalha junto, agora. Aí, ela chega e fala: "Qual a gente vai levar hoje?” Aí, eu falo tal... vira as costas e sai ... aquela tá boa. O pai dela manda sempre eu dizer pra ela antes, pra ela poder se arrumar, porque ela cuida do barzinho da frente. Isso aqui é uma espoleta, nem era pra ser nome Batatinha, era pra ser Espoleta. Ela sai do número dela e já vai ajudar a mãe dela no barzinho. Termina o intervalo, já vem prontinha pra fazer capilar ou malabares. É espoletinha mesmo.

Marcela: No começo, eu fico na cadeira. Começa o espetáculo, eu vou me arrumar pro palhaço. Depois, eu volto pra me arrumar pro Malabares. Depois, eu me arrumo de novo para Força Capilar.

Mario: Eu tive uma experiência muito ruim, uma vez. Eu tô levando a entrada da bancada e um rapaz quase me jogou pra baixo com um coice. Porque se você quer agradar tem que agradar com que faz, não com a outra pessoa. Mas eles querem agradar assim, com palavrões, com pimenta, mas eu não gosto, nunca gostei. Às vezes, um cara na bancada faz uma piadinha... eu respondo, só aquilo.

Marcela: Quando ele teve que visitar o filho dele que ficou doente, meu pai teve que se pintar de palhaço. Aí, ele teve que me ensinar a levar um número novo. 


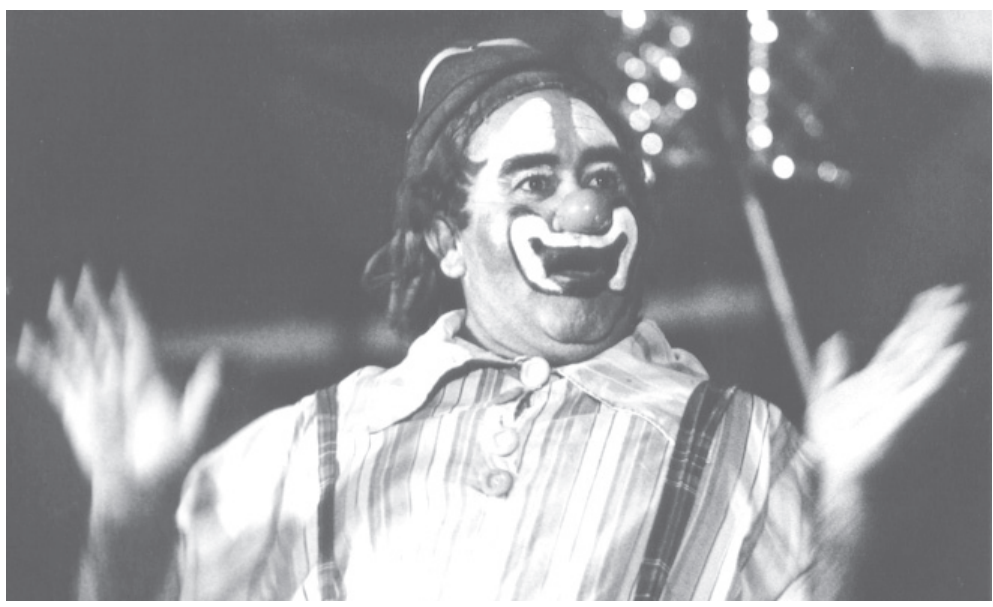

Mario: Viajei na última hora. Estreamos na sexta, e no sábado tive que viajar. Às vezes, quer levar coisa diferente, então a gente combina antes, é assim, assado. Mas com ela não tem problema, pega tudo na hora. É rapidinho, muito inteligente. Às vezes, a gente aumenta. Ontem mesmo eu aumentei a reprise. Não com ela, com ele [referindo-se ao pai dela]. Eu aumentei porque eu vi que tava bom, o povo era bom, então eu aumentei um pouquinho. Botei umas piadas no meio. Se eu vejo que tá ruim, não adianta. Não é aquilo ali e pronto.

Marcela: Eu também comecei a inventar umas coisas, que agradou. Quando um inventa. o outro vai atrás.

Mario: Não adianta deixar parado. Eu acho que a inovação que o palhaço tá fazendo o povo não tá pegando ainda. Então, eu tenho o estilo daquele palhaço antigo e as reprises tudo antigas. A juventude que não assistiu, não assistia circo naquela época, tá assistindo hoje. Aqueles que gostam, né. Então, minhas reprises são todas daquele tempo lá atrás.

A televisão matou muito. Agora não sei como é que tá, porque não assisto mais televisão. Os Trapalhões mataram muito o circo levando aquelas entradas, reprises de circo, tudo, tudo, eles tavam levando tudo. Então, o palhaço não tem opção. Quem olha a televisão, vê, depois esquece na hora. Mas acontece que fica ruim pra gente. 


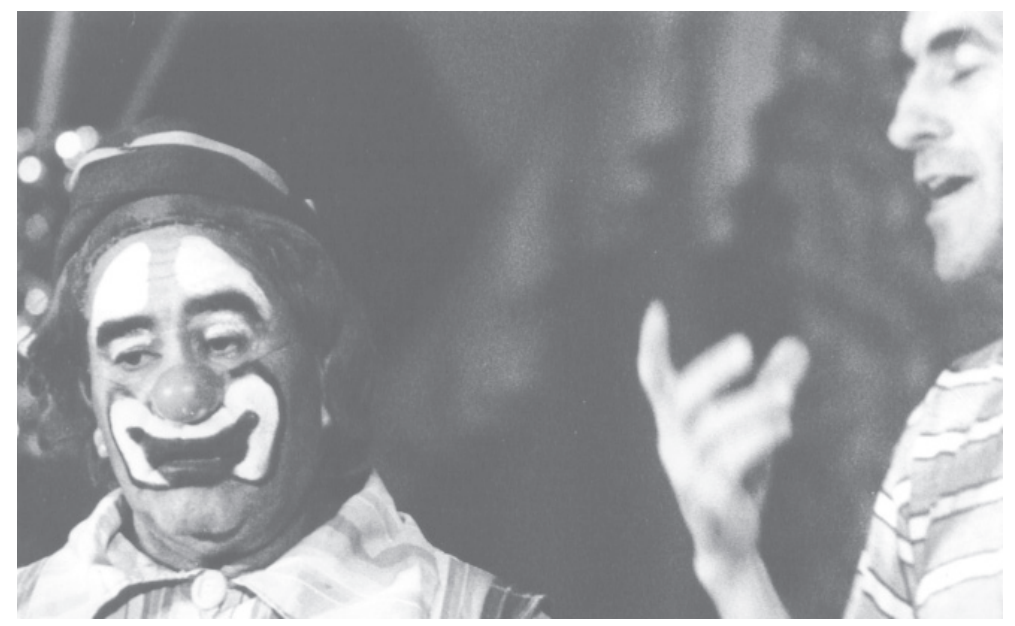

Eu, na minha parte, fico sentido, às vezes. E agora, com esse mágico mascarado, que eles tá fazendo... tá acabando com os mágico tudo. Como é que faz, tá mostrando tudo!? É muito dinheiro que tá correndo, isso aí é antiético. Não sei no que vai dar. Mas o circo, por enquanto, ele tá indo aos trancos e barrancos, mas tá indo. Não sei daqui uns anos mais, não sei!

Na cidade grande o povo tem muita opção pra ir. É muita discoteca, muito baile, todo dia. Anuncia segunda-feira tem baile, terça, quarta, quinta, sexta, sábado... então, o povo tem pra onde ir. Então, chega um circo em cidade grande, do nosso porte aqui, ninguém toma conhecimento. No interior, baile é de quinze em quinze dias. Então, chega o circo, a cidade que gosta, então eles vão. Aí eles dizem assim, que não tem dinheiro, mas vão num baile ali, a cerveja três real, cinco real o ingresso, e estão ali. Ali eles têm dinheiro, mas no circo não. 



\section{0 \\ TEATRO BIRIBA/Adriano}

O Teatro Biriba foi visitado nos dias 3 e 4 de fevereiro de 1999, na cidade de Santa Rosa-RS. A companhia dedicava-se, majoritariamente, à encenação de obras cômicas, comédias, chanchadas e esquetes. Alguns dramas eram também encenados, porém em menor quantidade. Vale lembrar que existem, atualmente, duas companhias de teatro sob a lona com o nome Biriba. Ambas são de um mesmo núcleo familiar: os Passos. A anterior, já documentada, é

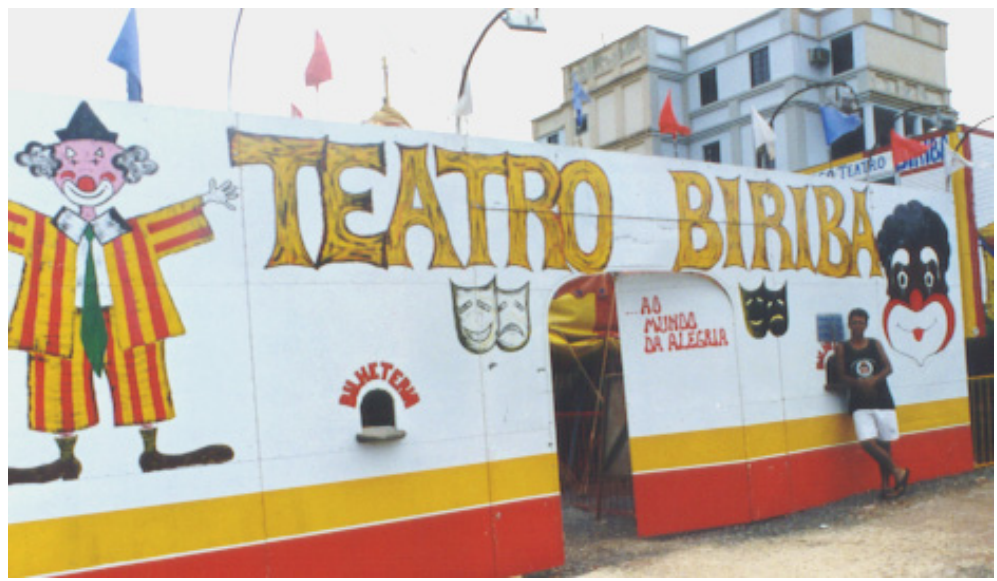



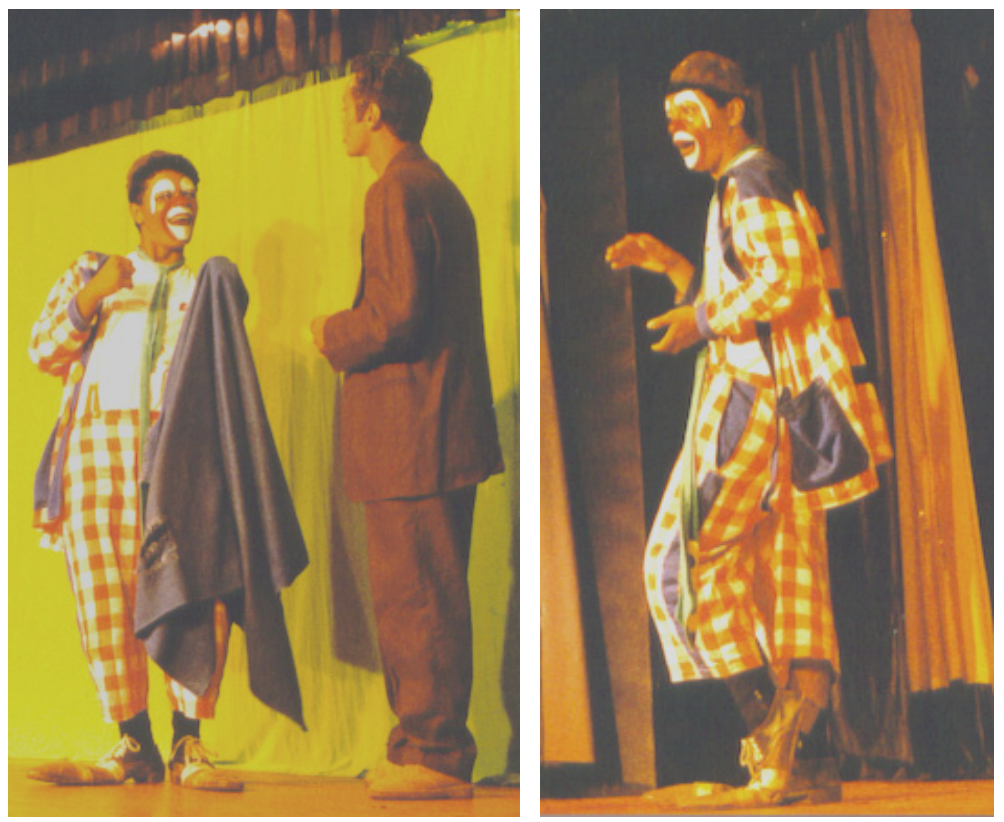

dirigida por Geraldo; esta é comandada por sua irmã, Aparecida, ou simplesmente Cida, como é conhecida.

A lona do Biriba era de, aproximadamente, 26 metros x 32 metros. Seu interior era montado para alcançar o propósito do palco à italiana. A cortina alcançava quase que todo o palco, restando um avanço de aproximadamente um metro de boca de cena. Em seguida, começavam as cadeiras. Atrás, uma arquibancada completava a plateia. A vara de iluminação frontal era composta por 21 holofotes. Além dela, havia iluminação de fundo e de pino.

\section{Comédia do dia: Biribinha em "Não aperta, Aparício"}

O espetáculo do Teatro Biriba, na noite de 3 de fevereiro de 1999, constou de uma comédia, Biribinha em "Não aperta, Aparício", um 
show com bateria e guitarra, dançarinas e intérpretes e, por fim, um esquete, "Morrer pra ganhar dinheiro".

As comédias, quase sempre, trazem o nome do palhaço da companhia no título. Esta não fugiu à regra e teve como personagem principal o Aparício, interpretado pelo palhaço Biribinha. No primeiro ato, a cena apresentou um senhor recém-casado com uma mulher jovem. Ele tinha um filho adolescente com uma outra mulher, que escondia de sua atual esposa. O filho, contudo, veio ao encontro do pai. Aparício (palhaço Biribinha), um velho amigo de infância e adolescência, chegou a sua casa e acabou assumindo, por imposição atrapalhada do marido, a paternidade.

O recém-casado morava com a sogra, que era "viúva": o marido se perdera em uma viagem. Não se sabe, portanto, se estava vivo ou morto. A velha queria se casar novamente e colocara anúncio em um jornal. Por este motivo, apareceram na casa o Aparício e o Filho.

No Segundo Ato, a sogra está casada e totalmente transformada: ela se apresentou com peruca, óculos, minissaia, enfim, se transformara (caricaturalmente, é claro) em uma jovem. Veio apresentar seu novo esposo. Aparício chega e a empregada julga ser ele o marido da sogra. Imediatamente, encaminha-o para o quarto da velha, para as núpcias, criando a maior confusão. Em seguida, aparece o Filho, o atual esposo da Sogra. Assim, ele fica sendo sogro de seu verdadeiro pai e pai de sua madrasta. A confusão se generaliza, até que o antigo marido da sogra ressurge para desfazer todo o equívoco.

Toda a ação se voltou para a interpretação do palhaço, motivo central de todo o riso. A exemplo dos esquetes e reprises, o texto em si mesmo não apresenta tiradas cômicas: além das falas e marcações de entrada e saída de cena, ele encaminha os encontros e desencontros. A graça só parcialmente está no texto escrito. A eficácia cômica desses encontros e desencontros, contudo, depende da forma de atuação do palhaço. Este tem a liberdade de improvisar. Muitas vezes, o palhaço insere trechos de esquetes e entradas que são do conhecimento dos outros atores, e a encenação toma um outro rumo. A peça, então, acaba sendo um fio condutor, um eixo genérico a partir do qual a ação se desenrola. Neste aspecto, a participação do apontador (o pon- 
to) é essencial: nos momentos necessários à retomada do enredo, ele reintroduz o texto, para que haja continuidade do espetáculo.

Por dedicar-se exclusivamente ao teatro, o Teatro Biriba apresentava-se com cenários adequados a cada peça. Nesta relatada, o cenário era uma sala de estar da família, com sofá, poltrona, mesa etc. Além dos elementos cenográficos descritos, também se contava
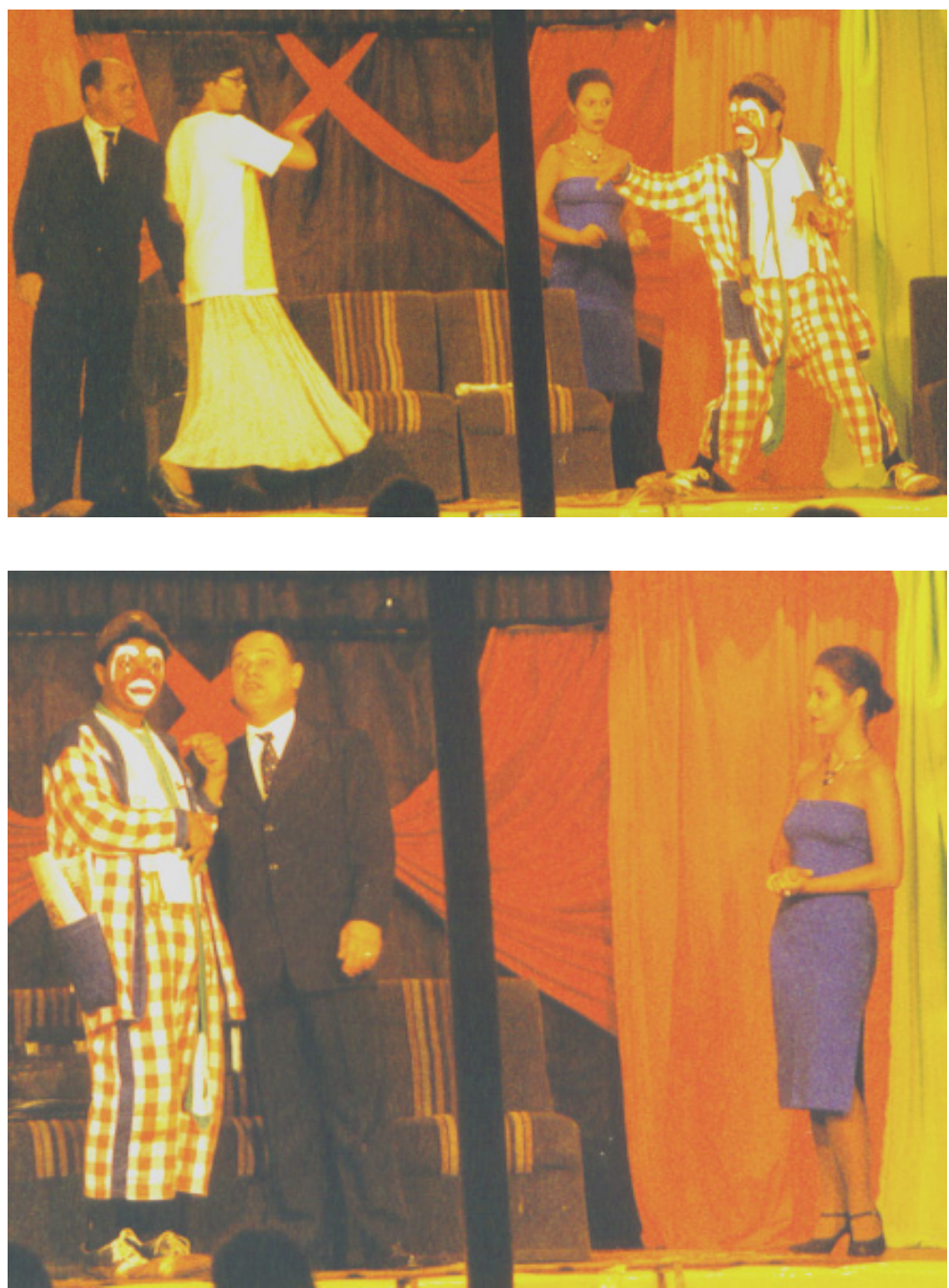


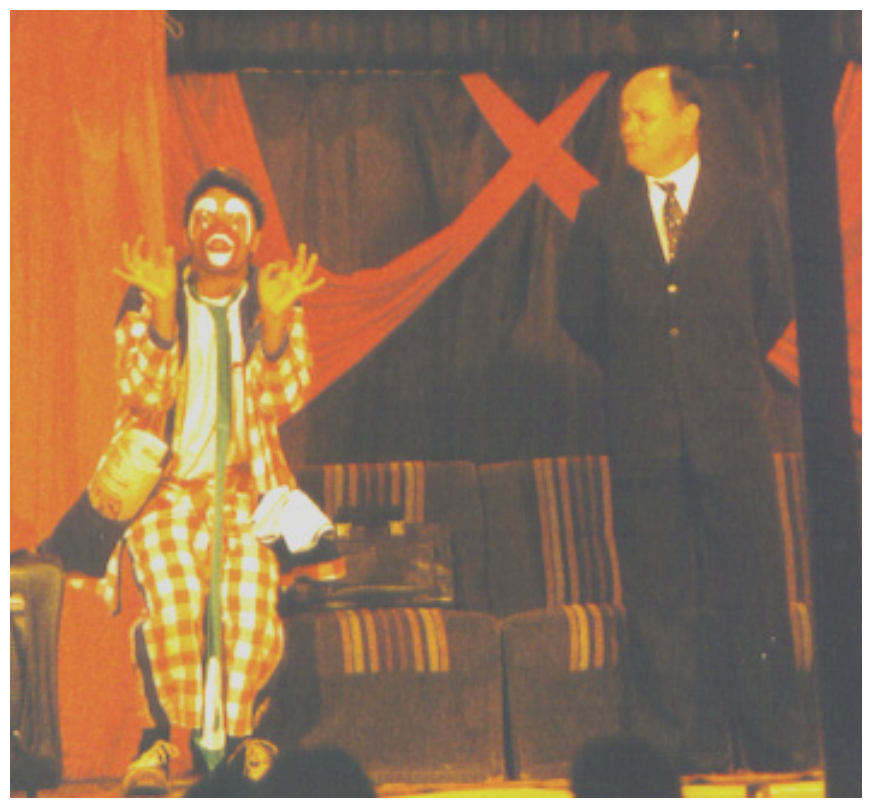

com a presença de um telão de fundo, que fazia referência ao ambiente exterior. Comédia ou drama, o fundo do palco não se prestava à entrada e saída de personagem: como em muitos teatros, os pontos de entrada e saída eram laterais.

\section{Biribinha}

O palhaço da companhia Teatro Biriba apresentava-se como Biribinha. Ele é Franco Adriano Passos Rosa, neto do Biriba, formador da companhia. No Circo di Monza, o palhaço, Geraldo Santos Passos, também tinha o nome de Biribinha, e vem a ser tio deste último. Atualmente, Geraldo adotou o nome de Biriba.

A entrevista investigou o processo de criação e concepção da personagem. Nesse processo, o colocar-se diante do espelho para a maquiagem tem um papel preponderante. A maquiagem é um dos momentos de concentração e preparação da personagem. Para alguns 
artistas, esse processo é lento, meditativo, como um ritual de iniciação que se dá a cada função, a cada espetáculo. A correria que antecede o acender das luzes e as diversas funções que cada elemento assume na organização do circo e no espetáculo propriamente dito nem sempre propiciam adequadamente os minutos de atenção para com a personagem. Entretanto, os palhaços preocupam-se sobremaneira com esse momento de contato com a individualidade do artista e a do palhaço/personagem. Esse tempo de introspecção pode ser decisivo para a boa performance em cena. Escondido em uma máscara/ maquiagem o artista revela-se. Talvez neste ponto resida uma das diferenças entre os palhaços da atualidade e as personagens/máscaras da Commedia dell' Arte italiana: estas estão asseguradas pela tradição de figuras/conteúdos coletivos; os palhaços apresentam traços de uma individualidade. Biribinha já tinha a noção desse momento.

Biribinha tinha uma indumentária próxima à do avô, Biriba. A maquiagem também. Em cena, Biribinha apegava-se a gestos e poses demarcados. $\mathrm{O}$ gesto preparado com atenção, envolvendo os mínimos detalhes e todas as partes do corpo e do rosto, encaminhava melhor o riso. $\mathrm{O}$ artista tinha a noção da importância deste tempo de preparo do gesto.

Biribinha dominava com maestria o recurso do "à parte", especialmente no gestual. $\mathrm{O}$ gesto dirigido à plateia, ainda que abrupto, conseguia estabelecer o intervalo necessário para o devido distanciamento do enredo e do texto (já que este, em si, não traz muitos momentos cômicos) e buscava nos mecanismos não emocionais do público um riso qualificado e, assim, dava ao palhaço e sua interpretação o grande lugar da comicidade.

Depois da comédia, Biribinha apresentou o esquete "Morrer pra ganhar dinheiro".

\section{Entrevista}

Nasci em 30 de novembro de 1973, na cidade de Pomerode, e desde que nasci tô atuando no circo-teatro. No primeiro dia que 


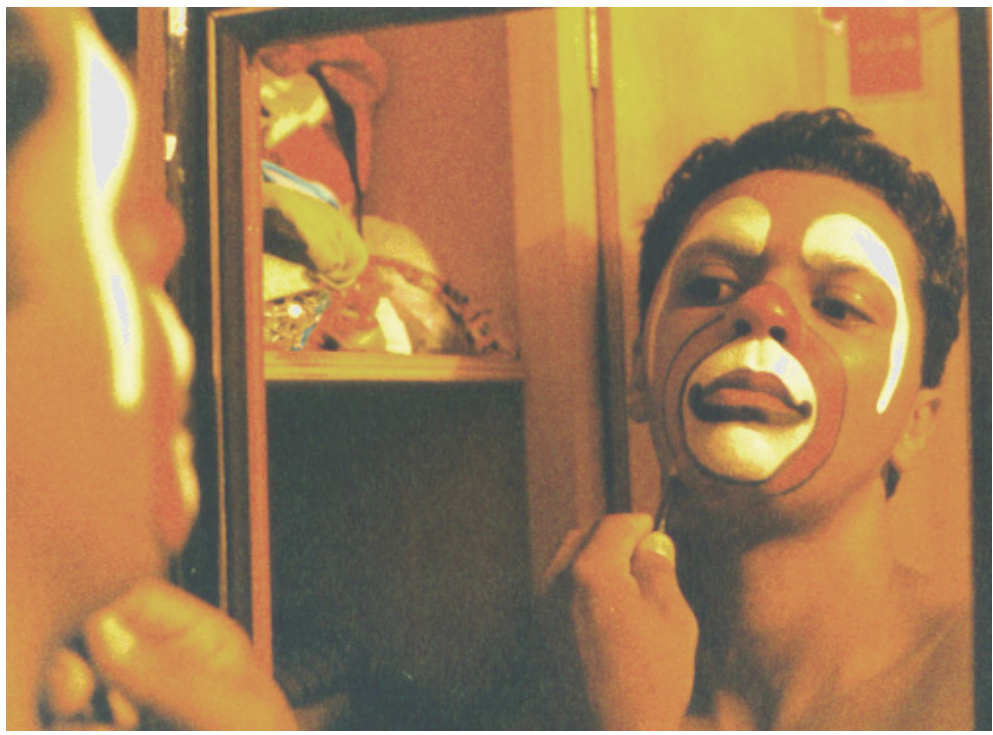

eu voltei pra casa, eles precisavam de um nenê pra peça e já me colocaram.

Quando você começou a fazer o palhaço Biribinha? No dia 12 de junho de 1992, mas antes disso eu já fazia palhaço infantil, nas matinês. De 89 a 92, eu fiz palhaço infantil. Meu nome era Bimbo. Depois, quando meu vô morreu, eu comecei a fazer o palhaço Biribinha.

Hoje em dia, a criança não quer mais saber de Sítio do Pica-Pau Amarelo. A mentalidade da criança mudou. A gente sentiu que precisava dar uma mudada nisso. Então, a gente tinha que colocar um pouco mais de malícia. Não pode extrapolar também, falar coisa direto, mas colocar um duplo sentido.

Cada cidade tem o seu jeito de trabalhar. De acordo com cada público tu vai mudando o teu jeito. Isso é até bom, porque tu não fica bitolado num jeito só. Quando a gente chega na cidade, a primeira coisa que eu faço, eu procuro um "bragatiano" - que eles chamam militar aqui - e pergunto pra ele: "Qual é a vila que a polícia mais baixa, que tem o maior índice de criminalidade, que é a vila mais famosa?". "Qual é a casa de mulheres, a zona mais famosa?". 
"Qual é aquele - porque toda cidade tem um louco - aquele louco que anda falando alto sozinho pela rua?”. Eu procuro assimilar isso no espetáculo. Também peço nome do prefeito, do vereador mais famoso, do médico ginecologista do posto de saúde mais famoso... Eu procuro fazer as coisas assim: pesquisar a cidade para aí incluí-la no nosso espetáculo, pra chamar a atenção do povo.

Tinha um senhor que ia assistir o espetáculo e eu sempre mexia com ele e ele gostava, nunca reclamava. Daí, tem uma música que a gente faz, "A prova da Manuela, o Manuelaelaelaelaela". A gente vai fazendo desafio, o meu irmão puxava um verso eu terminava outro. No final, ele falava: "Eu queria ser um rei no quintal da Manuela", e o final do verso é assim: "Eu queria ser água pra escorrer no rego dela”. Só que em vez de eu falar eu queria ser a água, eu falei o nome daquele senhor. Ele deu risada, me aplaudiu de pé. $\mathrm{O}$ véio gostou. No outro dia, ele veio fulo da cara comigo. O que é que eu tava pensando, que ele não era mais criança, uma água pra passar na "buceta" da mulher: "Não mexa mais comigo, tá pensando o quê??" Daí ele não foi mais no teatro. Um dia eu encontrei ele numa roda de amigos, ele falou assim: "Ah! Biriba, eu não fui mais lá porque tu não mexeu mais comigo”. Não entendi a do homem.

O nosso repertório ele tá grande, mas ele não tá o que a gente queria. Hoje em dia, o que o pessoal quer mais é comédia e comédia a gente tem umas 50 só. Drama a gente até teria mais uns 30 pra apresentar. Mas eles querem mais é comédia, então tu tem que trabalhar mais com a comédia.

Segunda-feira nós apresentamos uma peça, um drama. Nosso espetáculo é peça, show e esquete. Eles assistiram à peça, depois o show e a esquete. Quando eles saíram, a gente ouviu: "Mas a gente tem que escolher o dia pra vir, porque hoje o que valeu só foi o final do espetáculo". Então, eu não sei o que aconteceu com o povo, a mentalidade do povo. Não sei se a Revolução de 64 tirou totalmente a abertura das pessoas, fechou a mente das pessoas. De lá pra cá, o tempo foi passando e o drama foi sendo jogado de lado. Tá incutido na cabeça do pessoal que drama é ruim e comédia é boa. E não adianta a gente lutar contra todo mundo, né. A gente, infelizmente, tem que 
ser comercial. A gente tem que pensar é na nossa barriga, no nosso estômago, tem que viver. Se tu for querer colocar goela abaixo o drama, eles não vão. Eles vão procurar outro ramo de diversão. Aí a gente vai perder o público também.

"A maldição do lobisomem", que era um drama, a gente, apesar do passar do tempo, o pessoal foi adaptando aqui, ali e ela virou a maior comédia que nós temos no teatro. Era drama, há 50 anos atrás. Daí, foi fazendo adaptação e virou comédia.

O palhaço, no nosso espetáculo, é o que chama a atenção do público. O palhaço é o personagem principal. Tanto é que o nome da personagem, que é o nome do teatro, o nome das peças, leva o nome do palhaço na frente. Tudo gira em torno do palhaço. Se não tem o Biribinha, eles já ficam meio assim: "Ah, não tem o Biribinha nessa peça aí! Não mais é comédia”.

Nós temos 90 esquete feita. Esquete nós temos mais do que peça. Tanto é que quando a gente fica muito tempo na cidade, que as peças ficam mais escassas, a gente começa a emendar uma esquete na outra e anuncia "As trapalhadas de Biribinha", ou o "Biribinha segura o tcham", e daí a gente vai inventando os nomes e emendando as esquetes. E tem aceitação.

A gente é muito visado. Porque, como tem gente de circo boa, como tem gente de circo ruim, tem médico bom, médico ruim, advogado bom, advogado ruim. Então, a gente não pode generalizar tudo. Mas pra nós, não. Todo mundo de circo é ladrão, ou eles só vêm pra roubar o teu dinheiro, eles generalizam muito, circo, teatro, parque, todo mundo é ladrão. 



\section{1 \\ Teatro Serelepe}

Em Rosário do Sul-RS, nos dias 6 e 7 de fevereiro de 1999, foi encontrado o Teatro Serelepe. Semelhante às companhias Biriba, Serelepe também se dedicava ao teatro sob a lona. O circo era pequeno, com cadeiras e arquibancadas, palco frontal, cortina até o limite do palco e boa iluminação. Igualmente aos outros que se de-

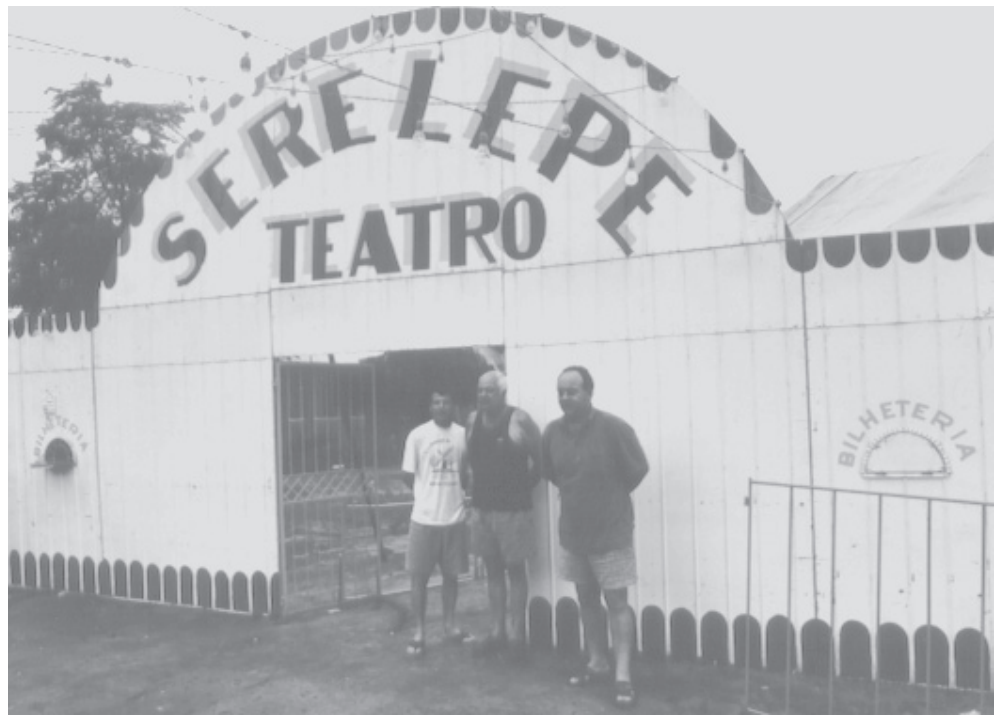


dicam ao teatro, a cena era composta por telão de fundo, bambolinas e saídas laterais.

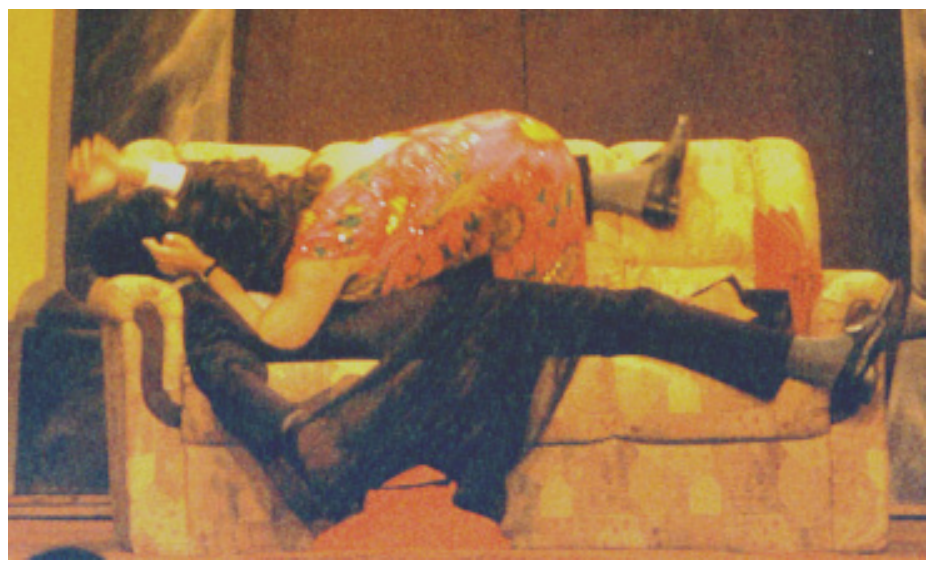

\section{Comédia do dia: "Essa velha tem fogo no fogo"}

A comédia anunciada e encenada, "Esta velha tem fogo no fogo", era a mesma vista em Santa Rosa, no Circo Teatro Biriba. Lá, incluíram o nome do palhaço no título; aqui, enfatizaram a personagem da sogra. As personagens são as mesmas: Raul, o patrão recémcasado; Vitória, sua esposa; Violeta, uma mulher chantagista; Alfredo, o filho que Raul não quer revelar à atual esposa; Carola, a doméstica; Ambrosina, a sogra; Aparecido, o sogro desaparecido; Aparício, amigo de Raul, interpretado pelo palhaço Serelepe. O cenário, com telão ao fundo, representava uma sala de estar de uma casa de família de classe média.

\section{Serelepe}

Na peça, Serelepe se apresentou como um caipira, com chapéu de palha todo desfiado, um paletó xadrez e calça listrada, ambos nas 


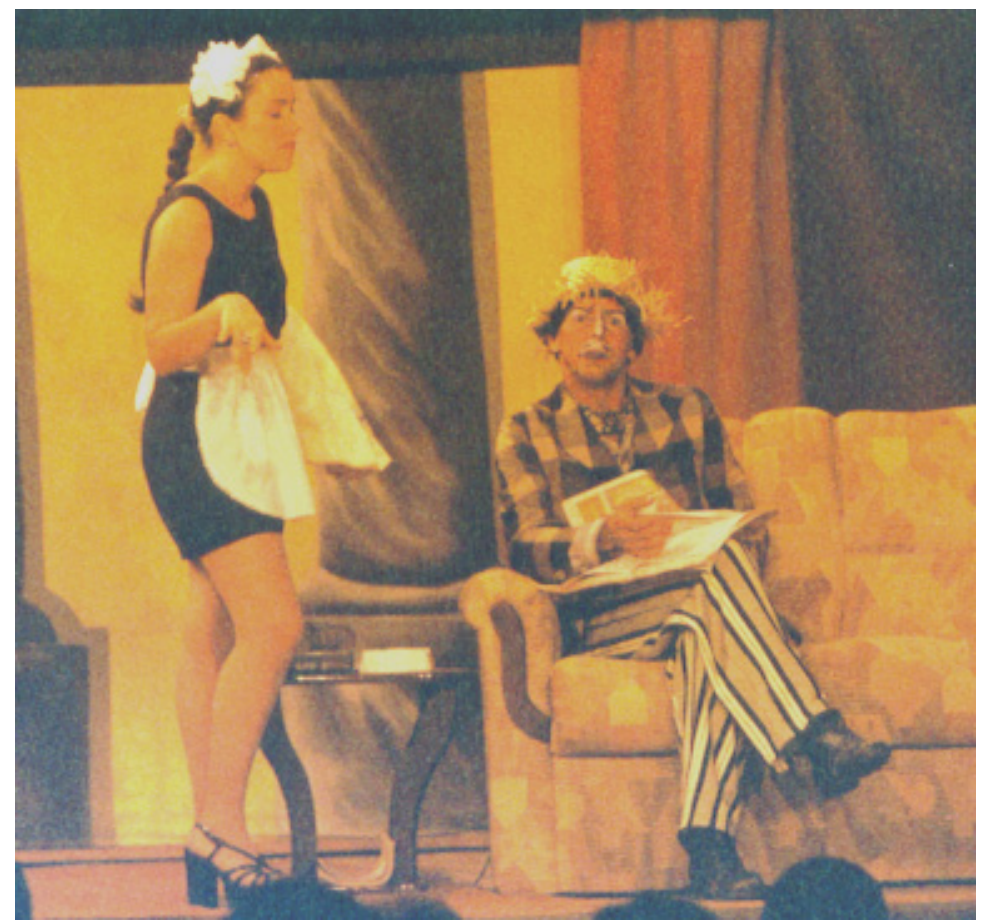

cores preta, branca e cinza. A maquiagem evidenciava os traços caipiras: barbinha rala, por fazer, e bigode, com destaques para a pintura branca e um pouco de vermelho. Quanto à interpretação, Serelepe mostrou-se bastante preso ao texto, com poucas saídas improvisadas. Os ângulos da luz frontal e o chapéu utilizado faziam com que uma parte de seu rosto ficasse na penumbra, inibindo a visão do público. Serelepe entrou com um microfone na lapela, o que provocou um desnível entre sua voz e a das outras personagens.

Serelepe fez uso intenso da triangulação com o público para buscar o riso e a graça. Comentários, expressões idiomáticas, reações diretas com a plateia, gestos alusivos à sexualidade foram constantes. Outro recurso fartamente utilizado foi o da mecanização do corpo humano, enfatizando a repetitividade e a abobalhação do homem. Mas, no central, o grande recurso do riso, na peça, é a confusão do enredo e de papéis sociais que as personagens assumem, a cada mo- 


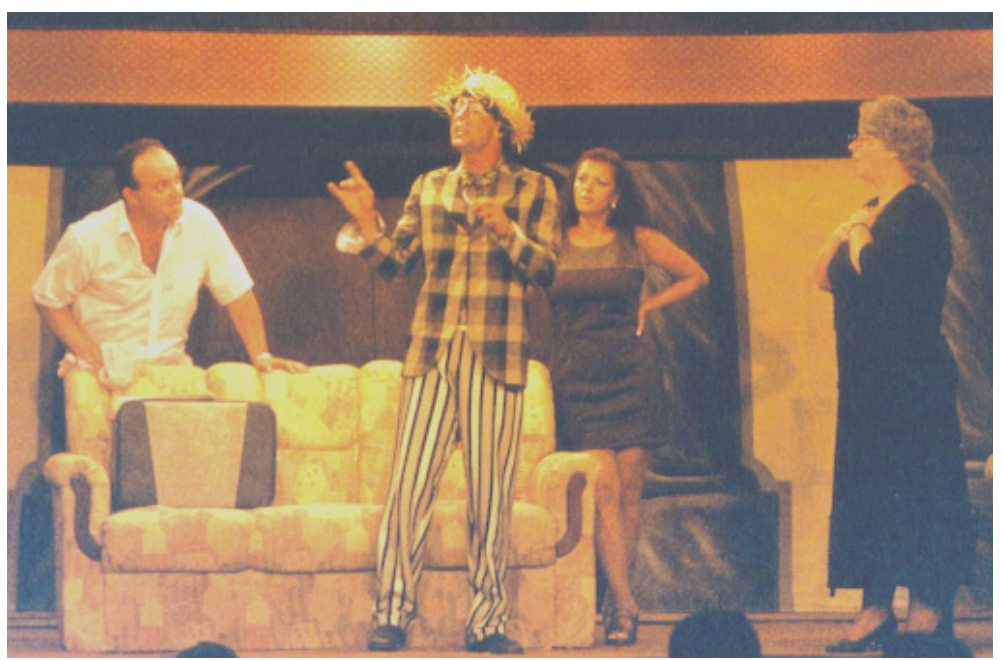

mento, de acordo com a situação: pai à força, no caso do Serelepe; o casamento inesperado da velha com Alfredo, filho legítimo de Raul, genro da velha; e assim por diante.

$\mathrm{O}$ apontador do texto teve presença marcante na peça. Em vários momentos, os atores perderam-se em cena e o ponto recuperou o roteiro original, o que foi notado pela plateia. Pôde-se ouvir um espectador comentar com seu amigo: "Você está percebendo que tem duas vozes falando!?".

Na segunda parte, o Teatro Serelepe apresentou um show musical, com guitarra e bateria, alguns cantores e cantoras e um pequeno coro de vozes femininas.

Em seguida, para finalizar o espetáculo do dia, foi apresentado um esquete cômico com Serelepe. Desta feita, ele se apresentou com sua caracterização própria: macacão, paletó e gravata, todos muito folgados e grandes.

O esquete apresentado, "Trajes da mulher", faz referência a uma briga de casal, por conta de um vestido que a mulher deseja: negro, fechado até o pescoço, comprido até o calcanhar, porém, decotado atrás, até a altura das nádegas, e nas laterais com uma abertura que vai do calcanhar até a cintura. $\mathrm{O}$ marido se nega a dar o presente. 


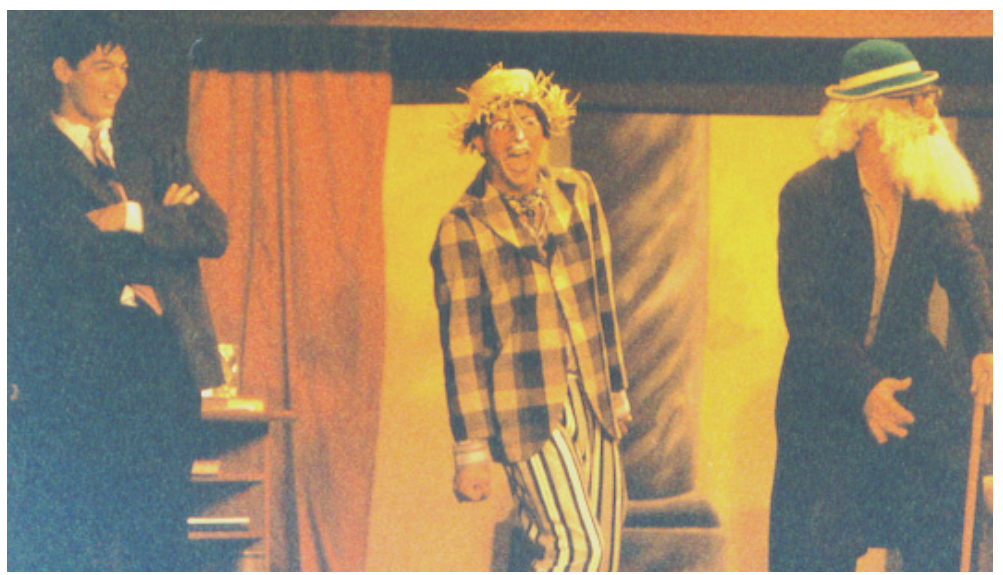

Ambos pedem a opinião do Serelepe. Ele vai concordando com a mulher, até chegar na abertura lateral. Também não concorda com o modelo do vestido. $\mathrm{O}$ casal briga e a mulher volta à casa dos pais. $\mathrm{O}$ marido recorre ao amigo Serelepe para ajudá-lo a fazer com que a mulher retorne. Primeiro, tentam telefonar, ou melhor, Serelepe faz uma confusa ligação, quando termina falando apenas com a telefonista. A comicidade em torno do telefone e da telefonista passa a ocupar o enredo.

Em seguida, os dois tentam escrever uma carta à mulher. Serelepe vai ditando. Primeiro, uma carta com palavras duras: "pauladas", "porradas" etc. Depois, com palavras doces: "meu docinho de coco... minha bananada (indica o pênis) não pode viver sem a sua marmelada" etc. Finalmente, com palavras carinhosas e amorosas, que saem de dentro: "fígado", "coração", "tripas" etc. Para finalizar, forjam uma doença do marido: ele engoliu a língua e está mudo. Ensaiam a farsa e a cada momento um detalhe prejudica o desfecho feliz. Por fim a mulher retorna, encontra o marido e o Serelepe mudos. Ela anuncia que ganhou na loteria e ambos gritam eufóricos. Cortina. 


\section{Entrevista}

Marcelo Benegoto de Almeida, o Serelepe, nasceu em Santana do Livramento-RS, em 29 de junho de 1969. Atua como palhaço da companhia desde 1994.

Fui escolhido pelo pai e tô aí há quatro anos. Eu herdei o nome dele. Eu uso microfone porque eu perdi a minha voz quando eu tinha 12 anos. Eu trabalhava num grupo de teatro em Curitiba e fazia três espetáculos por dia. Terminava o espetáculo, eu molhava a cabeça com água gelada e, naquela época, na mudança de voz, eu forçava muito a garganta e fui perdendo a voz e fiquei rouco. Trabalhei no Teatro Guaíra seis meses. Me serviu muito. O diretor era uma pessoa bacana e eu aprendi muito... aquele negócio que você ensaia três meses. Não é como a gente que ensaia duas vezes e já tá levando. Lá é um teatro muito elitizado. Eu gosto mais do povão, gosto da risada alta, do pessoal aplaudir, tem que pedir silêncio. Lá não, o pessoal entra, fica quieto, assiste o espetáculo e vai embora. Não

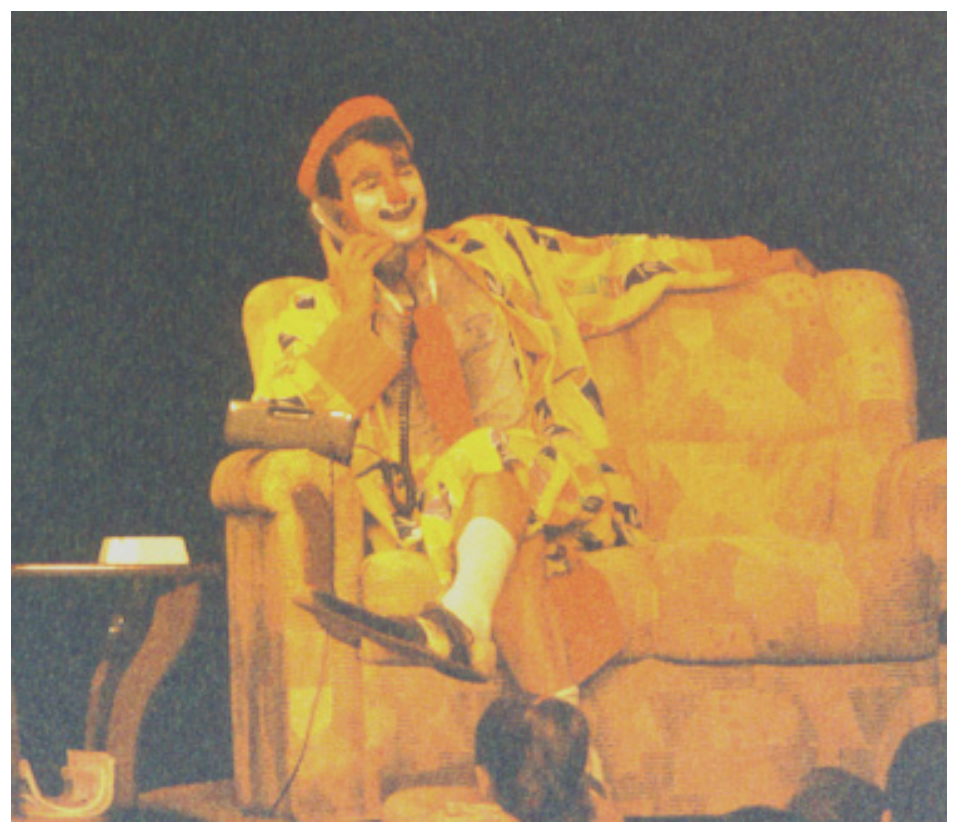


existe esse calor. Em Curitiba, nós trabalhamos com as quatro paredes. Aqui não: nós trabalhamos com três paredes. A quarta parede não existe para nós, porque o trabalho é interativo com o público.

Eles querem uma coisa mais obscena. Eles querem um gesto mais forte, eles querem um palavrão no meio da piada. Mesmo as crianças que frequentam o teatro, mesmo porque, na televisão eles mostram coisa muito pior. Eu me considero um tipo de palhaço meio bagaceiro, como dizem. No dia da estreia, eu não faço muito gesto,

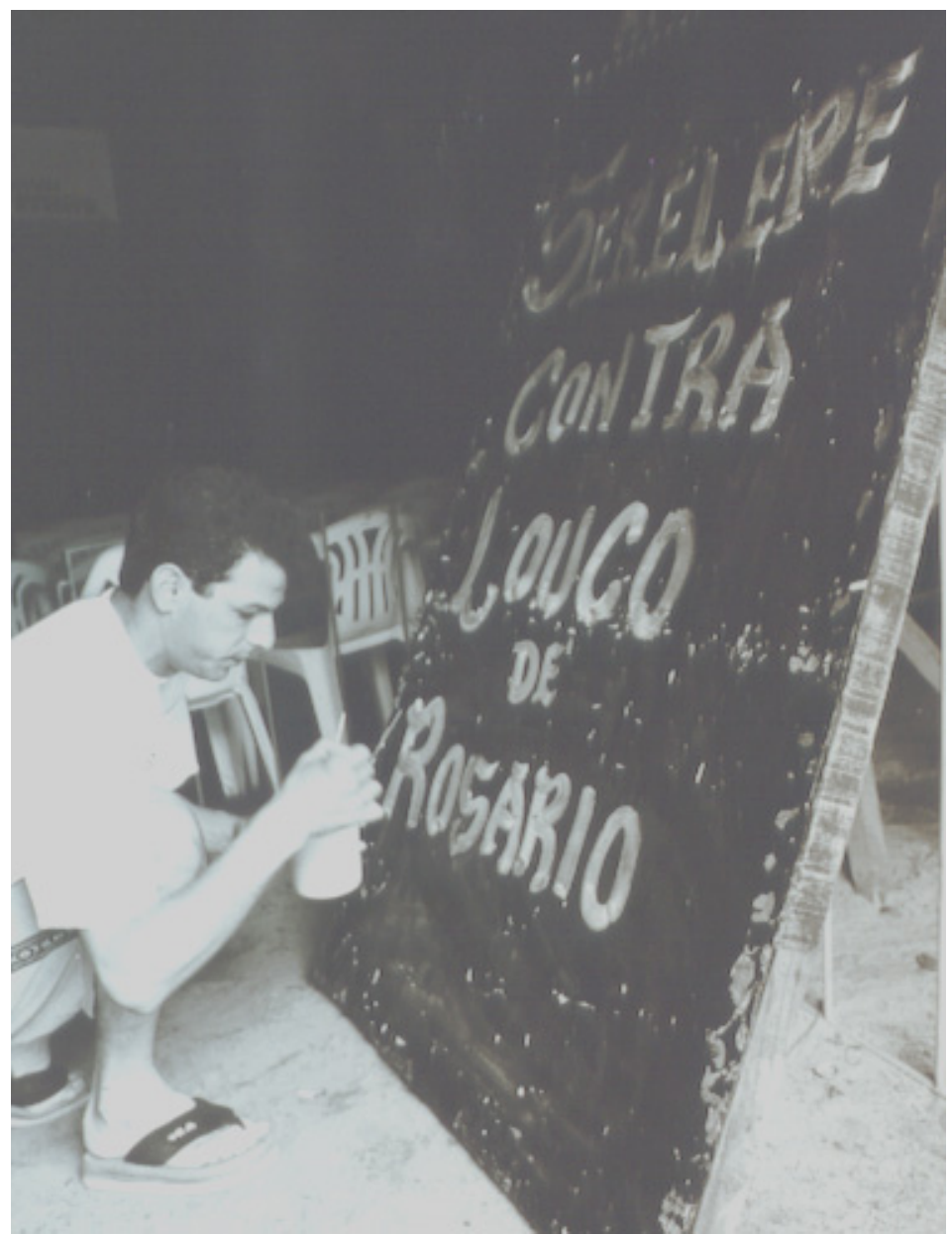


não digo palavrão, pra testar a plateia. Largo uma de vez em quando, pra ver como que é o público, se o público vai aceitar ou não. Tem público que não aceita, logicamente. Aí, tem que se controlar, não pode fazer gesto, não pode dizer palavrão, mas se tu ver que o público aceitou, chegou a bater palma em cena, tu pode falar o que quiser.

Porque a comédia, ela vem num pique assim, subindo, o pessoal vem dando risada, dando risada, depois para! Aí cai. Depois, pra levantar aquele pessoal de novo é a coisa mais difícil do mundo. Tem que ter um certo pique no palco.

A maioria das comédias nossas é na base do improviso, o conteúdo, o roteiro é só mesmo pra gente acompanhar. Quem puxa a graça é o escada, o palhaço só dá o desfecho da piada. Tem peça aí que precisa ser atualizada, com texto muito antigo. Escritores do tempo em que o arco-íris era preto e branco. A gente vai atualizando o texto dele pra modernizar um pouco mais, pra ficar de fácil entendimento do público.

No circo, o que mais aparece são aqueles números aéreos, de magia. O palhaço aparece só pra completar. Aqui não, o palhaço é o espetáculo, essa é a diferença.

Mas o povo não quer saber de chorar, ele já levanta de manhã chorando. 


\section{2 \\ Teatro Bebé}

O circo do Teatro Bebé era de lona nova, de sistema tensionado, tipo castelo, e quadrada (21metros x 21 metros). A plateia era composta apenas de cadeiras, e o chão era recoberto por um tablado. $\mathrm{O}$

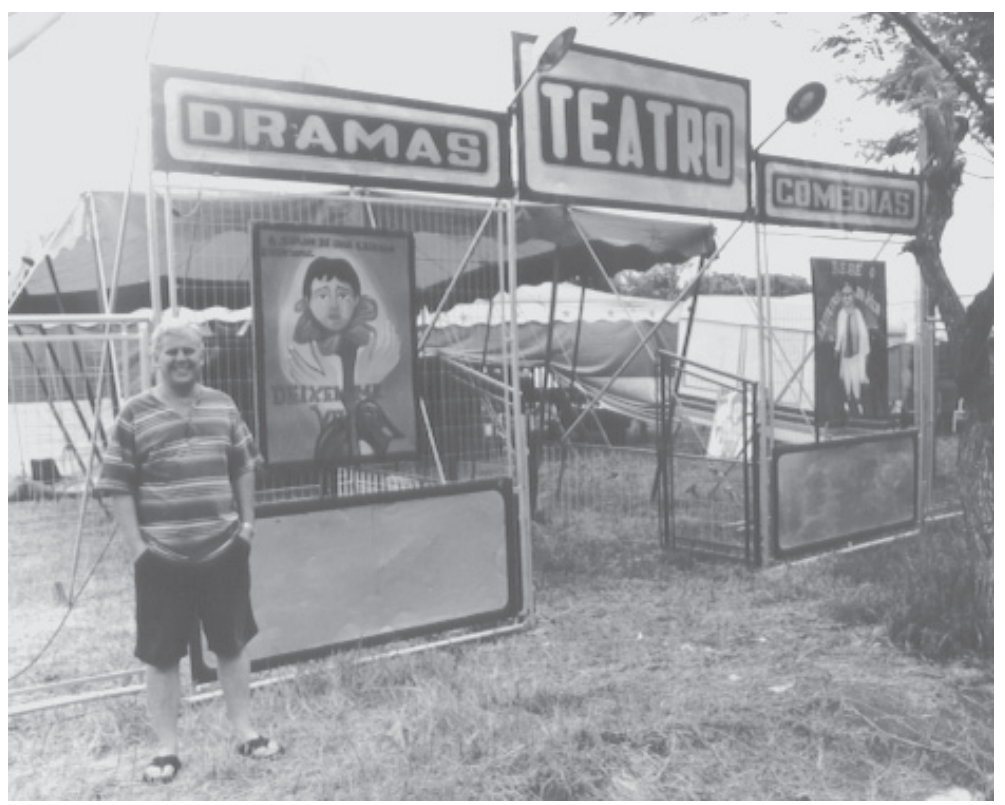




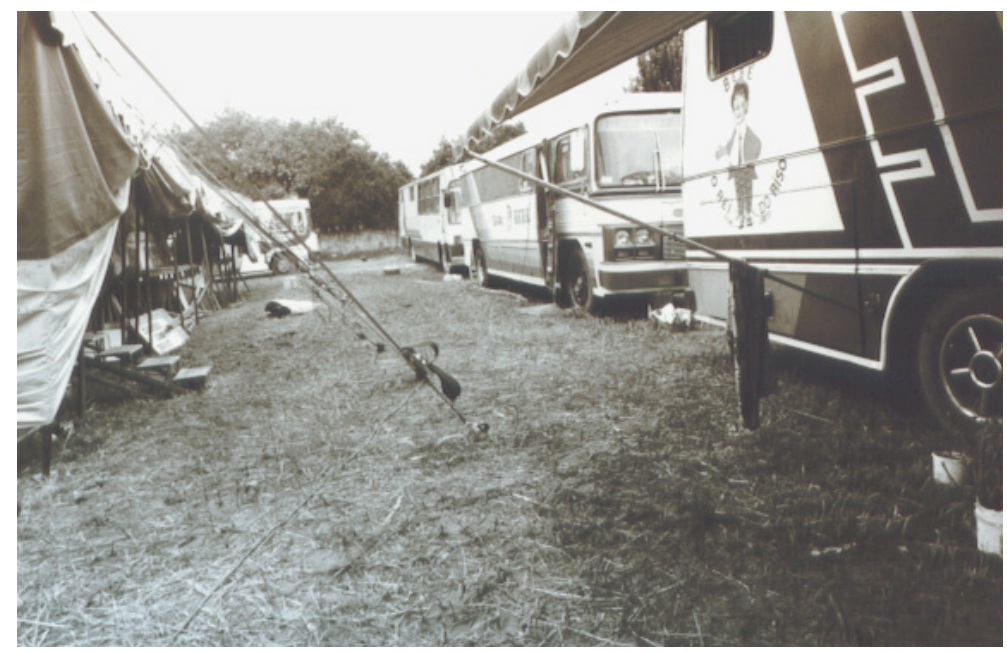

palco era frontal e tinha uma cortina arredondada e dourada. A companhia dedicava-se exclusivamente ao circo-teatro, com predomínio das comédias. Foram vistos dois espetáculos do Bebé, em Restinga Seca-RS. No primeiro dia, a companhia apresentou a comédia "Bebé e o soldado recruta". No segundo, 8 de fevereiro de 1999, foi apresentado um melodrama, "O padre e o assassino", seguido de um esquete, "Bebé, o empregado do barulho", o mesmo visto no Teatro do Serelepe. Tanto a comédia como o drama e o esquete estão detalhados e analisados no Capítulo 6, "O palhaço e o grotesco", no livro Palhaços, São Paulo: Ed. Unesp, 2003, p.163-84.

\section{Entrevista}

José Renato de Almeida, o Bebé, nasceu em Ponta Grossa-PR, em 1955. Trabalha como palhaço desde os 15 anos. Levando um estilo apimentado, Bebé consegue dosar as brincadeiras com o público. Considera importante a maquiagem adequar-se ao rosto do artista. Segundo ele, sua personagem representa suas frustrações. Bebé, embora esteja satisfeito com sua profissão, reclama muito das condições hostis dos circos pequenos. 


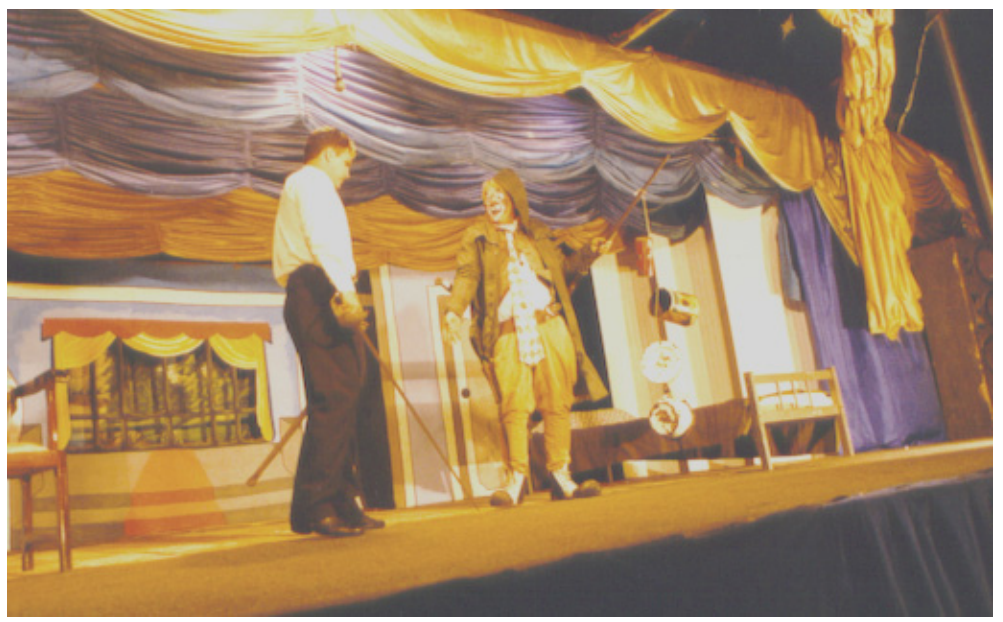

\section{Bebé}

O público gaúcho, se não tem o palhaço, para eles, não tem graça, tem que estar com a cara pintada. Eu não achava que dava pra isso, mas a sobrevivência, aquele negócio de ter que sobreviver já com filhos, porque eu casei com 15 anos. Eu trabalho com a mulher e os filhos.

Tínhamos pavilhão até 1987. Aí eu vi o circo e pensei comigo: "puxa vida, eu com um cirquinho desses trabalhando, só eu e minha família, o que desse na bilheteria, pipoca, maçã, ficaria tudo para a família, poderíamos sobreviver até tranquilamente!" Fizemos um nome e estamos sobrevivendo deste nome até hoje. Mas apoio mesmo, só o público.

$\mathrm{Eu}$ acho que o governo deveria dar mais incentivo pra gente. A gente é muito marginalizado. Eles não sabem o bem que a gente traz pra cidade. Às vezes, eu chego na cidade, pergunto pro vizinho se pode ceder uma água. Água, meu Deus do céu!! Vai na Corsan, aqui no Rio Grande do Sul, e os caras não querem ligar. A gente fica sem água.

Eu casei muito cedo. Meus irmãos, parentes, disseram que eu ia ser o corno mais novo da família. Quer dizer, com 15 anos eu já ia 
164 MARIO FERNANDO BOLOGNESI
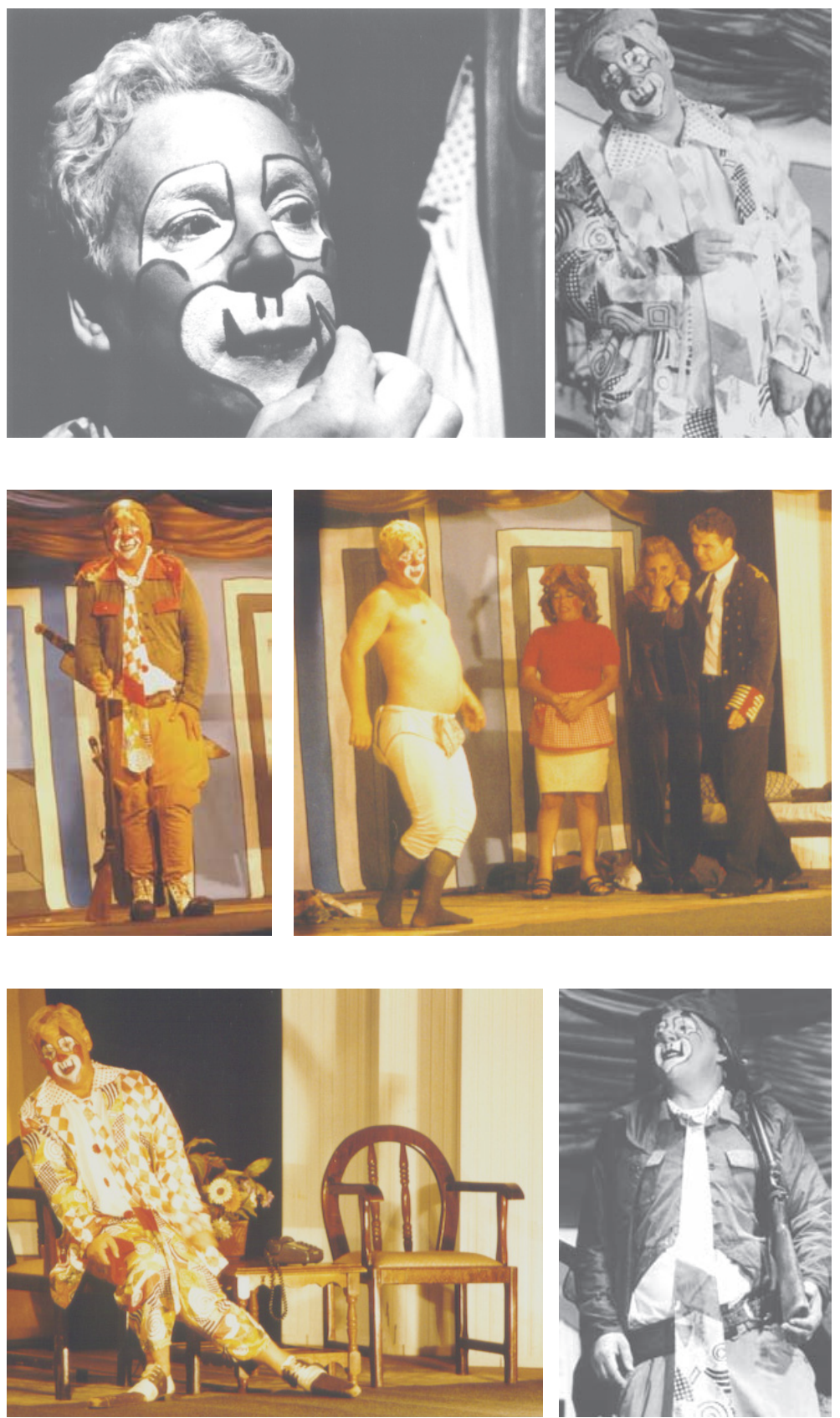

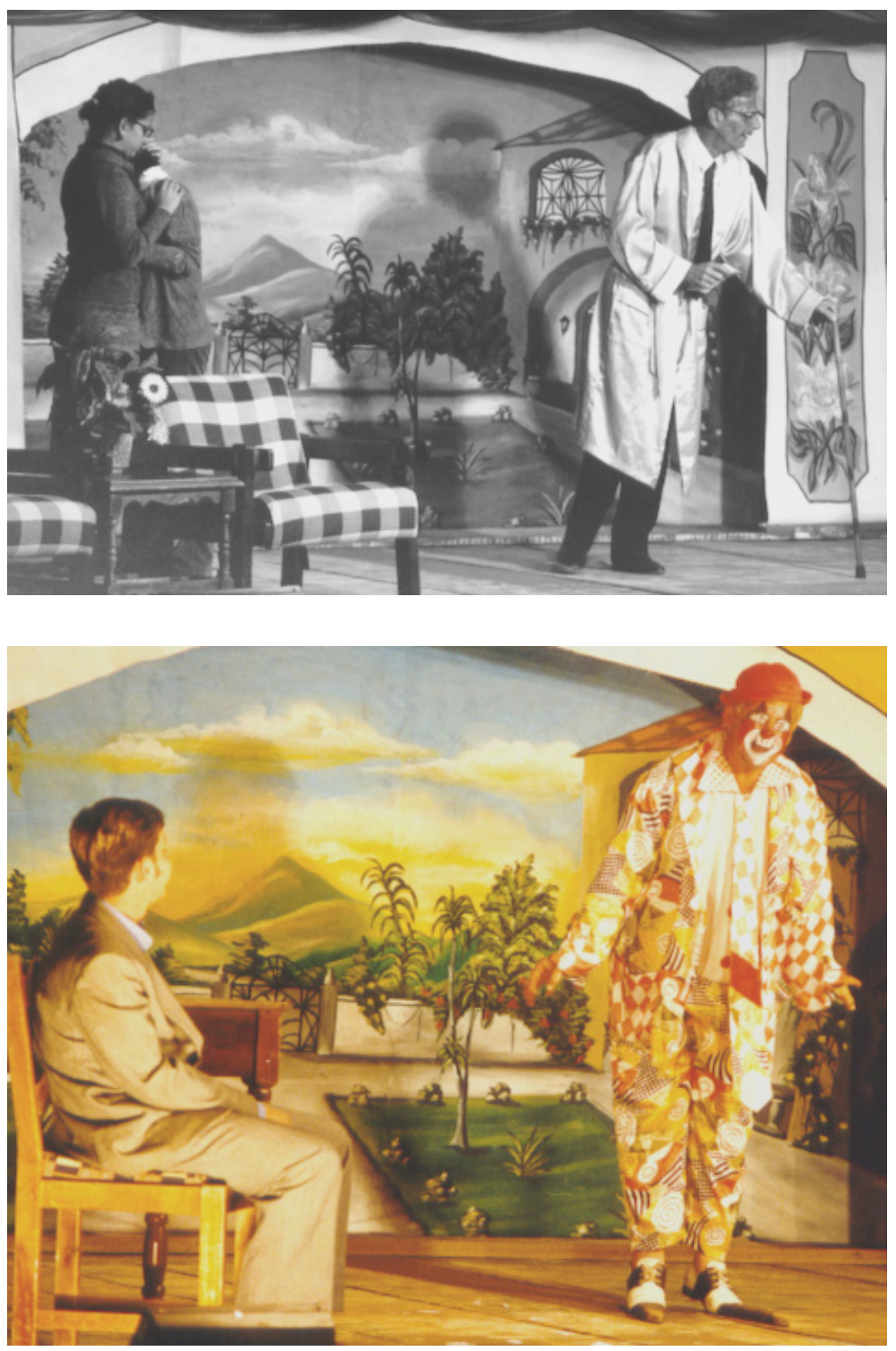
ser corno. Touro eu não podia ser. Eu tinha que ser uma coisa pequena, um cabrito. Quando eu entrei com a minha esposa na igreja, na hora da marcha nupcial, eles faziam assim: Bé Bé Bébébé (no ritmo da música). Eu ficava bravo, xingava, mandava eles pr'aquele lugar. E ficou, porque todo apelido que a gente não gosta, fica.

Eu posso não ter a roupa toda, mas o meu chapéu eu tenho que ter. Cada um tem uma loucura. Tem que ter o meu chapeuzinho vermelho. Eu sou do estilo que palhaço tem que ser "chinelão". A roupa bem limpinha, mas não pode ser muito afrescalhada.

Fui mudando a maquiagem. Eu tenho um primo, em Garopaba, que foi um grande cômico, Tareco. Aposentado, agora. Quando eu decidi ser palhaço, eu me baseei nele. Até fico com tristeza, ele tá com 68 e não tem nada, uma gaita só. Às vezes, eu encontro ele na frente do espelho sentado, chorando. Minha pintura é praticamente baseada na dele. Essa pintura se assimilou muito com o meu rosto. Meus olhos realçam muito, dá um brilho incrível. O palhaço é uma coisa alegre, sorridente. A própria pintura, a boca pra cima, é sinal de alegria.

Como que você define o perfil do Bebé? Ele é malicioso, carente, espontâneo. Ele é alegre, sobretudo muito alegre. Quando a pessoa casa muito cedo é privado de muitas coisas. Então, eu acho que no Bebé eu ponho tudo pra fora. O personagem supre minhas deficiências. Às vezes falo coisas que na minha vida atual eu não falo. Quando eu tô revoltado com alguma coisa, eu aproveito o Bebé pra falar. Ele é minha válvula de escape.

Tu fala uma coisa, plateia dá risada. De repente, surge uma outra coisa, plateia dá risada. Aí, você volta no texto, e assim você vai explorando. A hora que dá aquela parada, tu entra no texto de novo. Na hora que surge uma nova gafe, você aproveita pra fazer. Eu privilegio os chavões.

Eu fiz uma apresentação em circo de picadeiro. Pra mim foi chocante. Picadeiro é muito diferente, é mais mímica, elasticidade. Mas eu não servia pra isso. Eu, se um dia tivesse um circo grande, eu faria um palco em cima de rodas. Tem que dar valor ao palhaço. Se 


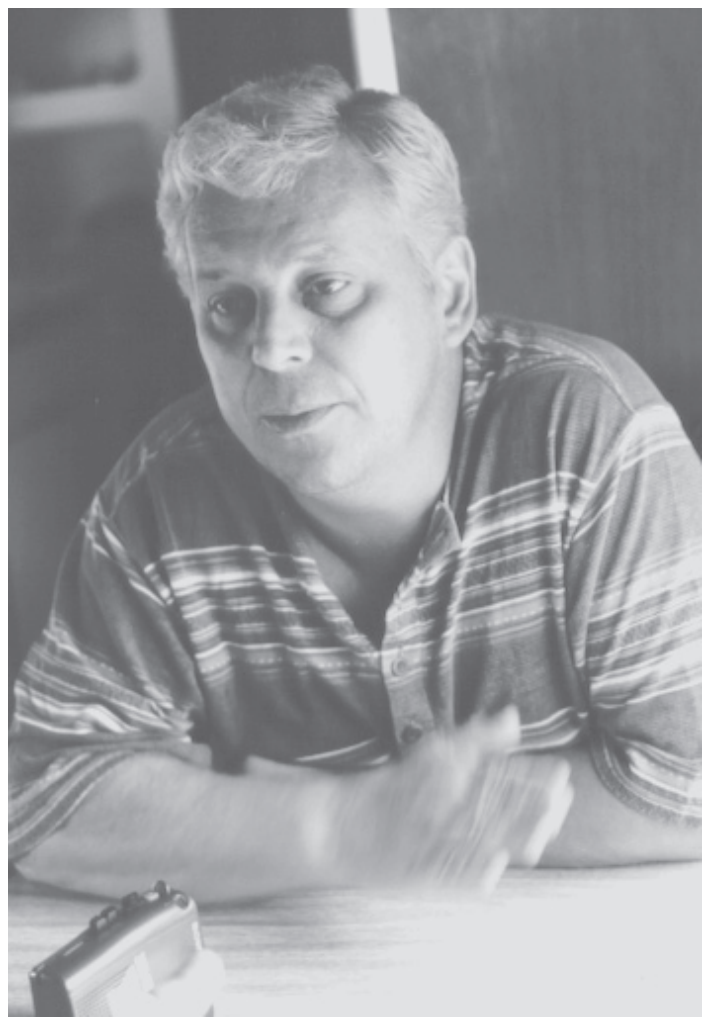

me dissessem, "você vai ter que fazer o picadeiro", eu acho que mandaria fazer um palco.

A alta comédia tem um centro só: um velho caçador, o velho cômico, uma caricata. Uma alta comédia não pode ter palhaço. A comédia com palhaço tem o script. A chanchada tem o palhaço, mas não tem o script. 



\section{3 \\ Teatro Popular de Curitiba PISKA-PISKA}

Em Campos Novos-SC foi encontrado o Teatro Popular de Curitiba Piska-Piska. Era um pavilhão, com estrutura de madeira, com as laterais e a cobertura de folhas de zinco. Um palco frontal, com aproximadamente 10 metros de boca, estava à disposição de uma plateia de 300 lugares, com cadeiras plásticas. Uma cortina de veludo vermelho escondia, antes do início do espetáculo, o interior do palco.

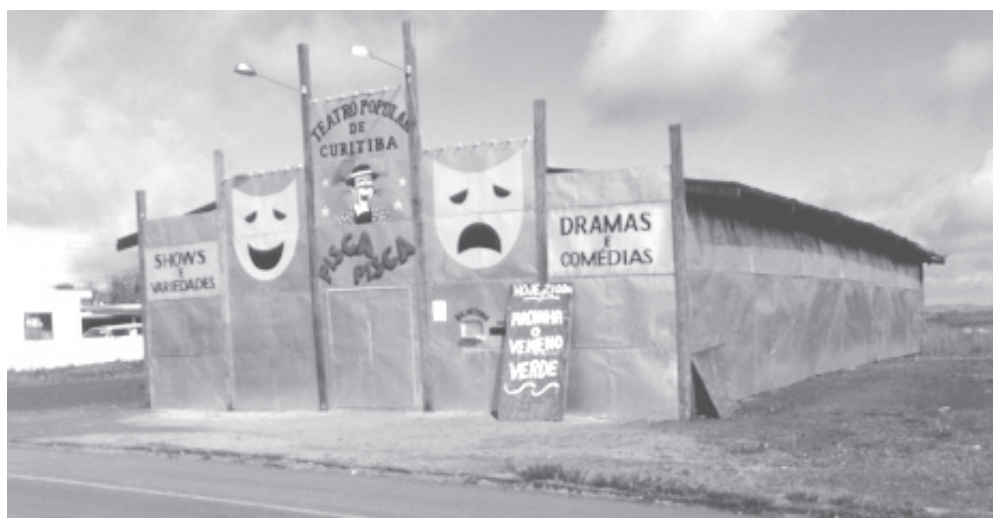




\section{Comédia do dia: "Piska-Piska no espeto"}

A comédia encenada em 10 de fevereiro de 1999, em Campos Novos-SC, pelo Teatro Popular de Curitiba, foi "Piska-Piska no espeto". Título original da obra: "Amor e comédia", de autor desconhecido. As personagens são: Gaspar, um ensaiador de teatro; Laura, sua esposa e primeira atriz da companhia; Terezinha, a empregada do casal; Poeta Carlos, o autor da peça a ser encenada; PiskaPiska, o criado do ensaiador.

No Primeiro Ato, o ensaiador está nervoso com a mulher, porque alguns de seus atores anunciaram que faltariam ao ensaio. Resolve sair para resolver outros problemas e diz à mulher que, se acaso o Poeta viesse, eles deveriam ensaiar a cena quatro, do segundo ato, uma cena de amor. Antes que isso aconteça, a empregada entra para uma pequena arrumação na sala da casa, mobiliada por um sofá à direita da plateia e uma poltrona à esquerda. Não havia telão algum no fundo. Em seguida, entra o criado Piska-Piska, que se engraça com a Terezinha. Juram amor e prometem se casar em breve. Mas Terezinha adverte, com uma faca na mão: se for traída fará uso do instrumento e colocará Piska-Piska no espeto. O Poeta chega (Piska-Piska chama-o de "pateta"). Era uma figura caricata, com maquiagem farsesca (do mesmo modo que a empregada). Aproveita a situação para ensaiar a cena de amor e, ao mesmo tempo, declarar sua queda pela primeira atriz. Antes do fim desejado pelo Poeta, em um momento acirrado da cena de amor, o casal é interrompido pelo Piska-Piska. Tumulto geral. Laura abandona a cena. O Poeta fica a sós com o palhaço e pede-lhe para entregar um bilhete à patroa. Sai o Poeta e retorna Terezinha. Vendo que está a sós com a empregada, e como irá se casar com ela, Piska-Piska resolve pedirlhe um "adiantamento" do casamento, ou seja, um beijo. Uma longa cena de trapalhadas se sucedeu. Quando, finalmente, Piska-Piska vai beijar a empregada, surge o patrão e o palhaço, de olhos fechados, acaba beijando-o.

No Segundo Ato, com idêntico cenário, o ensaiador, ainda mais nervoso, explica ao criado Piska-Piska o que é o teatro. Faz uma des- 

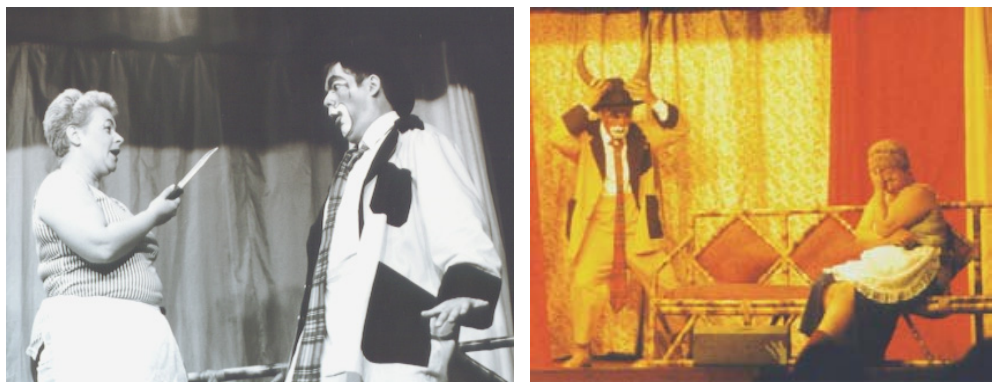

crição dramatizada de um teatro de ópera, desde a entrada até o foyeur, as frisas, camarotes, plateia, palco, cortina, fosso e orquestra, até chegar nas personagens. Passa então a representar, sozinho, uma cena de adultério. Em cada momento, representa uma personagem. Primeiro, a atriz; depois, o seu amante; finalmente, o marido que chega. O criado presta atenção a tudo, tomando algumas bordoadas, evidentemente. Sai o patrão e entra Terezinha. Piska-Piska reproduz à empregada o que é o teatro. Desta feita, o exemplo é o próprio pavilhão, desde a chegada na cidade, a montagem, a bilheteria, a plateia, o palco e as personagens. Tudo com muita paródia e gozação. Finalmente, vai representar as personagens, de acordo com os motivos anteriores, mas desta vez com zombaria. A cena era hilariante. O palhaço termina dançando com a empregada. Entra Laura e resolve ensaiar a cena de amor com o Piska-Piska. A cena termina com o casal marcando um encontro clandestino, no caramanchão. Piska-Piska leva tudo aquilo a sério e se entusiasma com a possibilidade de ser amante da patroa. Antes de tudo terminar, Terezinha entra em cena, com a mesma faca, ameaçando o criado. A patroa sai e restam os dois em cena. O noivado se rompe. Na sequência, o palhaço lembra-se de entregar o bilhete do poeta. Esquece, no entanto, quem é o destinatário (no caso, sua patroa/amante) e termina entregando-o ao patrão, Gaspar. Este se exaspera e quer tirar tudo a limpo. Todos em cena. Piska-Piska ainda não sabe o que está se passando e chama a patroa para irem ao caramanchão. Terezinha revela tudo e o palhaço sai perseguido. Fim. 


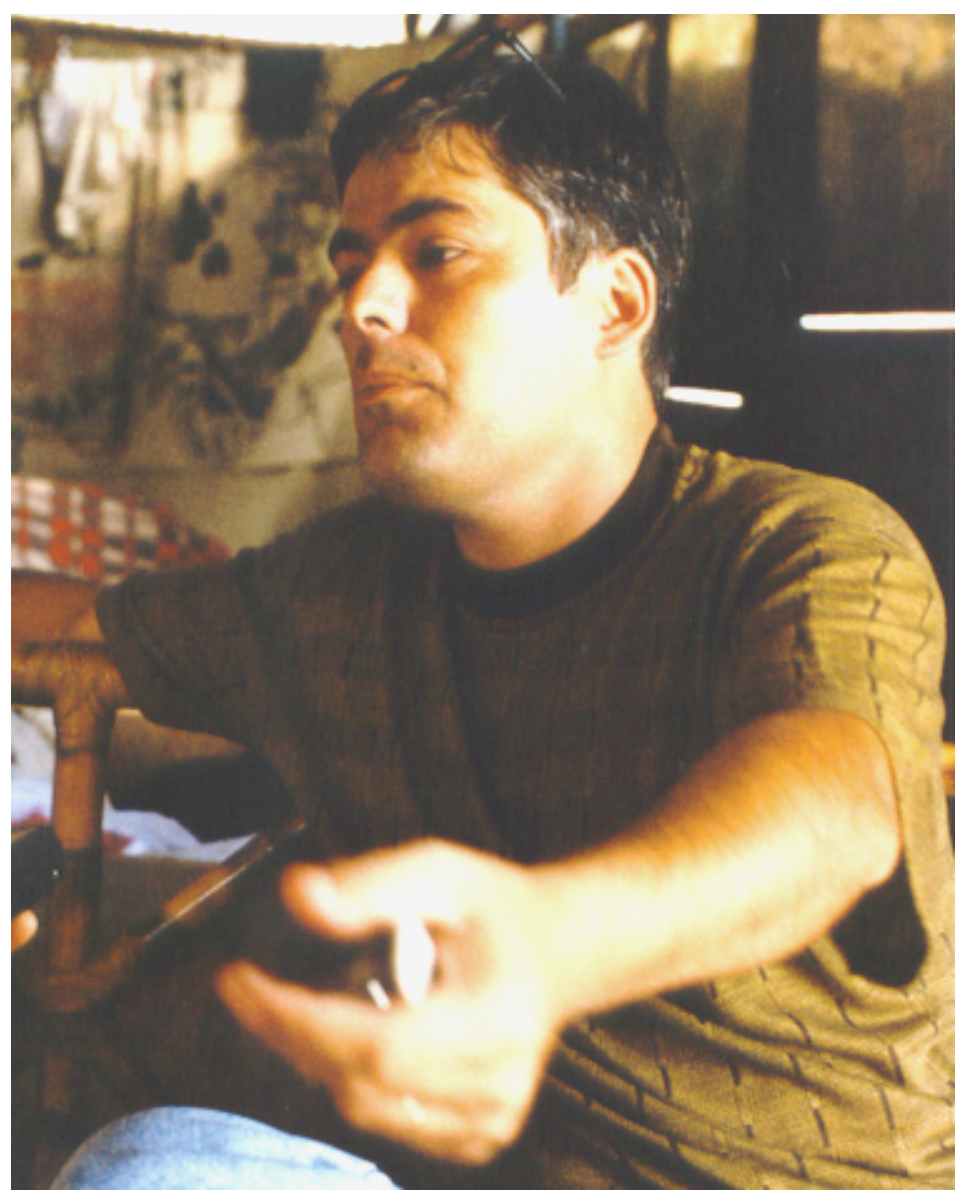

\section{Entrevista}

Gilson Pereira de Oliveira nasceu em Curitiba-PR, em 7 de julho de 1968. Interpreta o Piska-Piska desde os 10 anos de idade. Piska-Piska contou a sua experiência com o teatro fora do circo, tendo, como ele diz, conhecimento dos dois lados: teatro e circo. Ele tem curso superior de artes cênicas. Atuou em diversas encenações teatrais, tem sua própria companhia e encena melodramas e comédias circenses. 


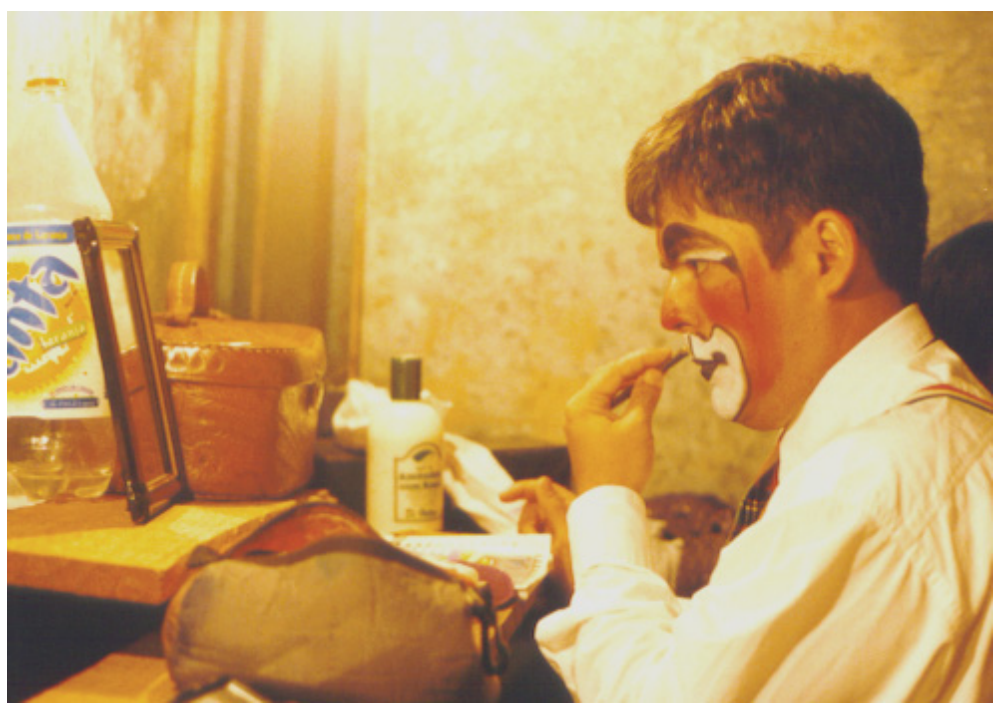

\section{Piska-Piska}

Hoje eu já não tenho tanto, mas na época eu tinha o problema de piscar rápido. Meu pai me batizou de Piska-Piska. Esse personagem que eu criei - eu não poderia deixar de falar - a gente sempre se inspira num ídolo. Eu sempre gostei muito do Biriba, seu Geraldo, o pai e avô dos Biribinhas, que estão dando continuidade ao trabalho dele. A gente sempre vai pegando o próprio estilo, mas eu comecei me inspirando no Biriba.

Eu procuro usar a segunda intenção. Pode até dar uma apimentada, mas com duplo sentido. Eu acho que pra você falar um palavrão em cena tem que ter um certo dom. Dercy Gonçalves fala um palavrão que não fere o ouvido dos outros. Ela tem um jeito todo especial. Eu costumo tomar bastante cuidado com isso.

Essa maquiagem passou por mais ou menos três ou quatro processos. Antes eu usava o branco em cima. Aí eu passei para o preto. Foi uma questão de se sentir bem.

Esse toque do Gilson, a parte infantil da minha maquiagem, é uma maquiagem de palhaço de circo. Porque dá pra diferenciar o 
palhaço de circo do cômico. O trabalho que eu faço hoje é de cômico. A maquiagem tem esse toque para o lado infantil, apesar de eu fazer um cômico pra adulto. Me identifiquei muito com as crianças, através da maquiagem, e acabei deixando.

Sempre tentam tirar o palhaço pra bobo, mas ele acaba se dando bem no final. Existe aquela mistura, malandragem, esperteza, mas nunca maldade.

Tem certas peças que a gente não tira do repertório, porque eles pedem. Tem certos trabalhos que eu procuro dar uma forçada, porque, dizem, o Brasil é um país que não tem passado. E eu acho que até concordo um pouco com isso, temos grandes valores na música brasileira e estão esquecidos aí. Eu procuro sempre resgatar. Às vezes falam: "O ébrio, de 1960? Isso aí já era!" O pessoal que conheceu a história, os mais velhos, e tem o pessoal que precisa conhecer. Vamos montar, pra que eles fiquem conhecendo. É a nossa tarefa, a nossa função. Eu procuro levar ele de época, até mesmo na questão do figurino.

Uma vez, eu tava fazendo um teste no Teatro Guaíra, pra uma peça, com o Ademar Guerra. Nós estávamos na sala de espera e eu tava conversando com uma menina que tinha feito faculdade de arte cênica. Eu também fiz faculdade de arte cênica, em Curitiba. Eu comecei a falar sobre o teatro, o tipo de teatro que eu fazia, teatro pavilhão, tal. Ela falou pra mim: "Desculpe eu ser sincera com você, mas eu acho uma falta de respeito com o público, você levar uma peça por dia". Eu falei: "Por quê?". "Falta produção, falta ensaio, falta tudo, eu acho impossível isso, eu acho que é falta de respeito." Eu falei pra ela: "Ô moça, você me desculpe, mas eu acho falta de respeito você fazer tantos anos de faculdade e acabar trabalhando pra uma pequena parte elitizada". Tem muita gente que nasceu, cresceu, já se criou e morreu dentro de Curitiba e não teve oportunidade de entrar lá dentro pra assistir um espetáculo. Acho falta de respeito, de consideração, esquecer desse público que não tem acesso ao Guaíra. Se eles não podem ir até o teatro, o teatro vai até eles.

O pavilhão sempre teve essa tradição: a gente sai um pouco fora do texto, brinca. A improvisação é uma das coisas mais difíceis. 
CIRCOS E PALHAÇOS BRASILEIROS 175

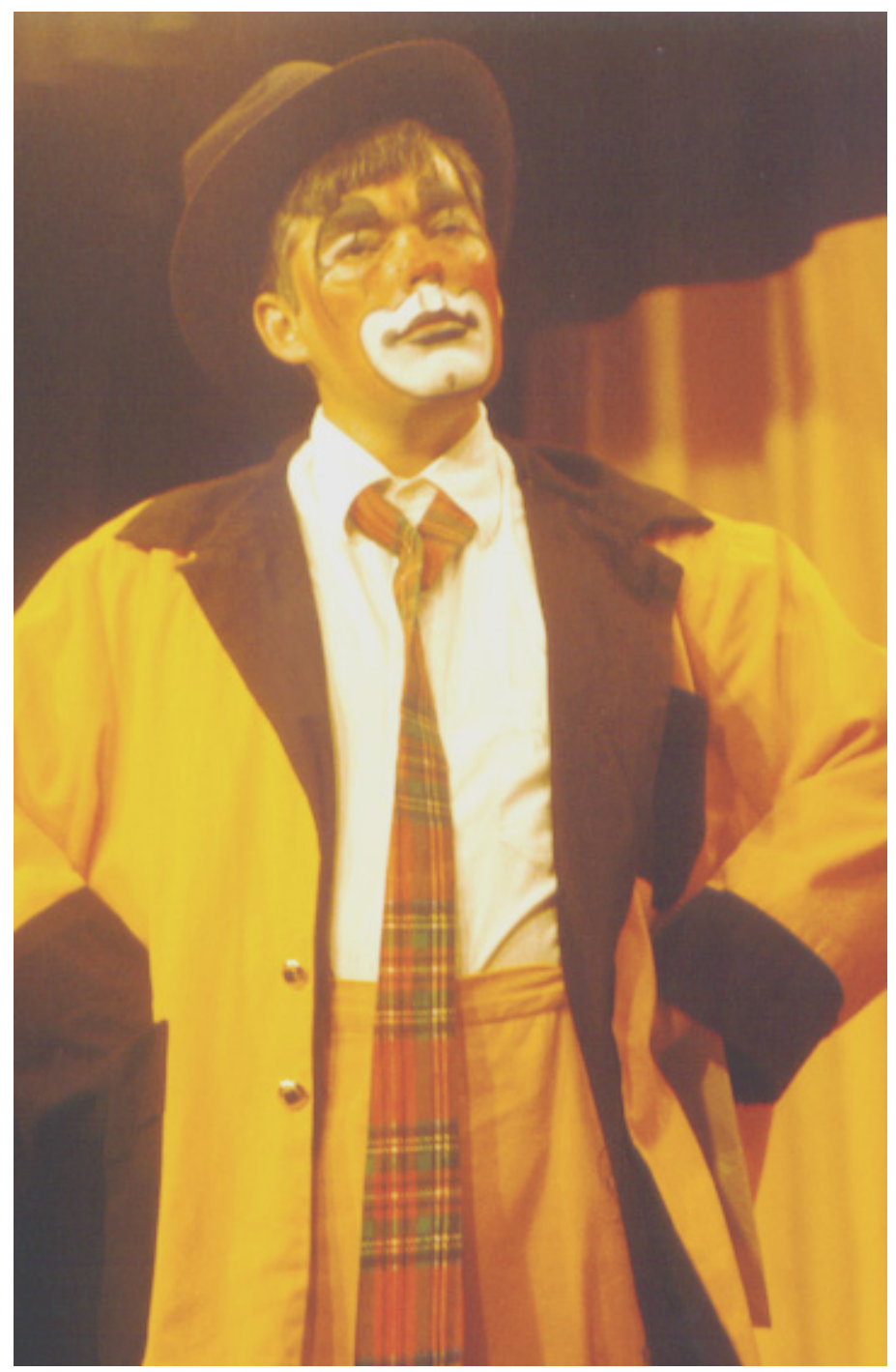


Quando acontece alguma coisa errada e você não sabe improvisar, fica parado em cena, fica uma coisa chata. A improvisação é muito importante pra todos os cômicos. No caso meu, é fundamental.

Infelizmente, ainda existe um grande preconceito; uma das coisas que eu ainda sinto e sinto muito é a questão do preconceito. Até mesmo com essa história dessa moça. Existe todo tipo de teatro, o teatro de rua, o teatro pavilhão, o teatro mais tradicional, o teatro mais moderno, o teatro de bonecos, e eu acho que todos têm o seu valor. Infelizmente, os alunos que estão saindo das escolas, eles saem com aquela coisa global, eles saem com preconceito. Deveria ser colocado na faculdade um pouco mais dessa nossa história, para que as pessoas pudessem, como o Ademar Guerra falou: "Procurem conhecer, viver, porque é uma grande escola!”.

O meu objetivo é esse: facilitar o acesso das pessoas mais carentes ao teatro. E está dando certo. 


\section{4 \\ Circo di Mônaco}

\section{Espetáculo}

Primeira parte: Adagas; Chupetinha em "Cidade de trás pra frente"; Fogo; Chupetinha e Soneca em "O boxe”; Trapézio Fixo; Soneca e "A Pensão da dona Estela".

Segunda parte: Rola-rola; Pirulito e o Dói-dói; Magia; Pirulito e Soneca no "Quadro vivo"; com a participação da plateia; Passagem nos trapézios.

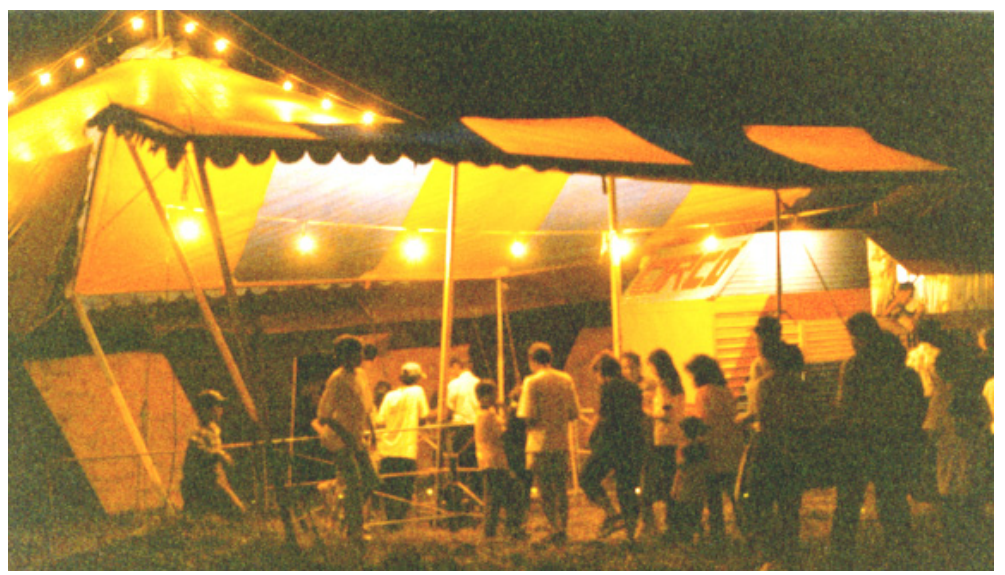



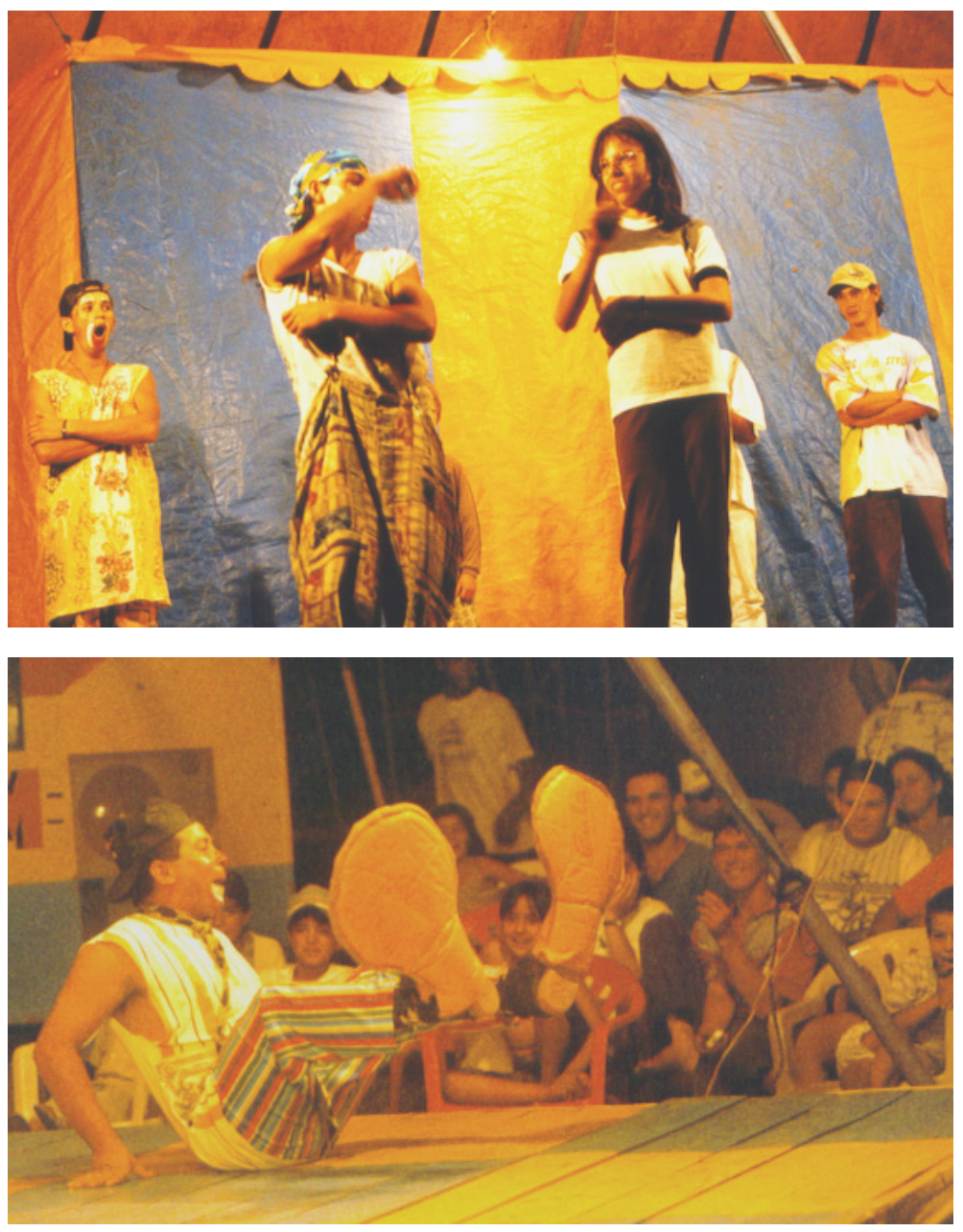

O Circo di Mônaco foi visitado em Pinhão-PR, em 12 de fevereiro de 1999. O circo era pequeno (18 metros x 24 metros) e dedicava-se ao espetáculo de variedades. A lona era surrada, com estrutura precária. O pequeno circo, apenas com cadeiras, estava lotado.

Os palhaços do Circo di Mônaco não se destacavam pelo visual. A maquiagem era das mais simples. Como os artistas tinham outras funções no espetáculo, Chupetinha (abaixo, à esquerda), por exem- 
plo, o primeiro palhaço, também fazia a magia e cuidava da lanchonete. Soneca (acima, à direita) e Pirulito participaram dos números de trapézio. O desempenho na interpretação também era frágil. Eles atentavam apenas para o encadeamento verbal das entradas e reprises, para salvaguardar a piada por meio da linguagem falada. 



\section{5 \\ Circo Balão Mágico}

\section{O espetáculo}

Primeira parte: Parada de mão com equilíbrio sobre cadeiras; Batatinha e o Apresentador em "Magia com patos"; Globo da Morte (com um aprendiz); Adagas; Batatinha e Coca-Cola em "O fotógrafo”; Trapézio em Balanço; Lira; Contorção; Pêndulo; Paródias musicais.

Segunda parte: Corda indiana; Macaca; Táxi Maluco; Globo da Morte.

O Circo Balão Mágico foi visitado na cidade de BandeirantesPR, em 21 e 22 de agosto de 1999. Tratava-se de um circo de médio porte, de dois mastros, com boa estrutura física. Em seu interior, o espaço era dividido entre um modesto picadeiro, um setor de cadeiras e arquibancadas. $\mathrm{O}$ espetáculo era composto apenas de números circenses.

\section{Batatinha}

Batatinha tinha 12 anos de idade e começou a entrar no picadeiro, como palhaço, aos 10. Sua performance foi contida, com excessi- 
182 MARIO FERNANDO BOLOGNESI

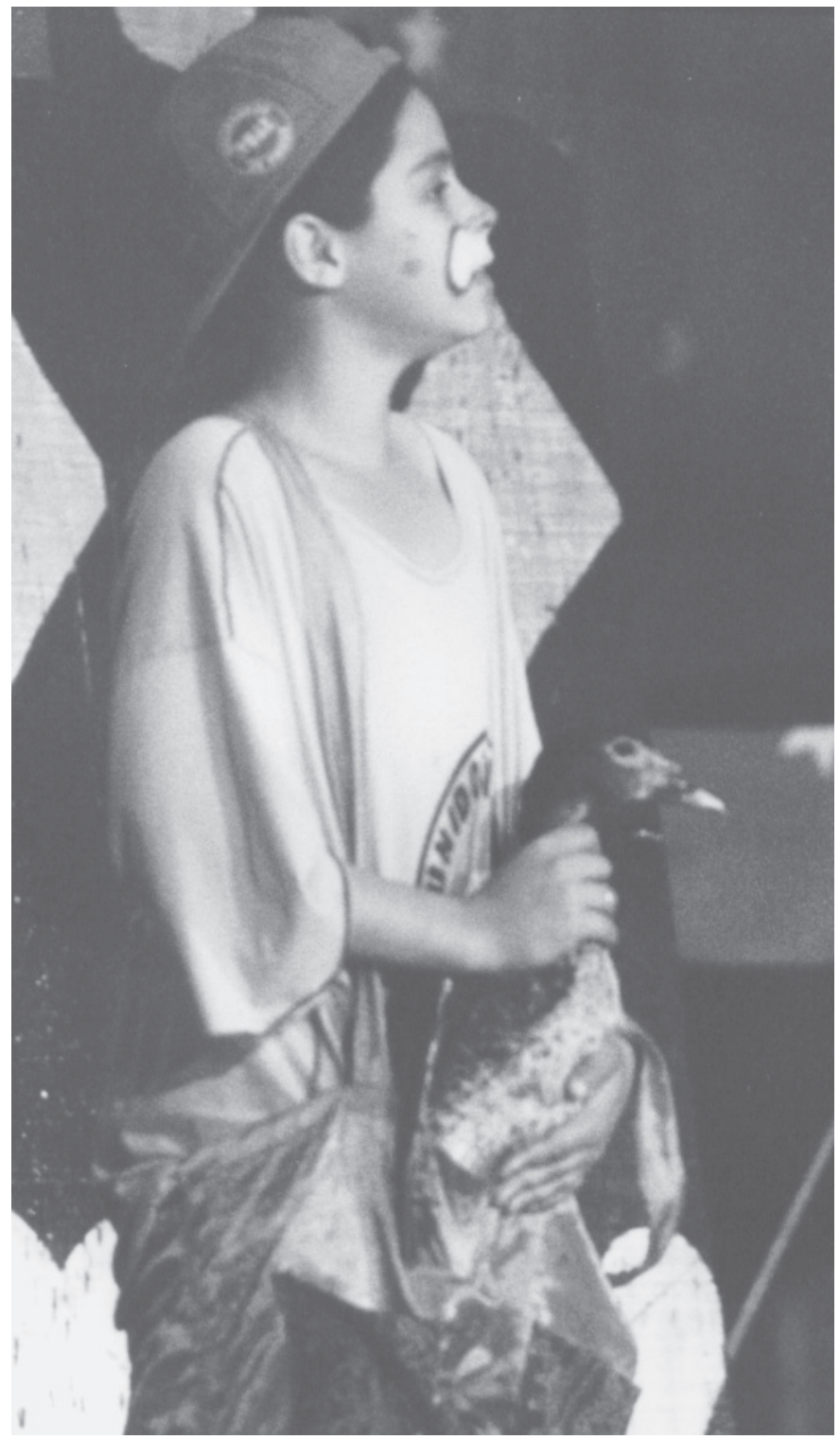



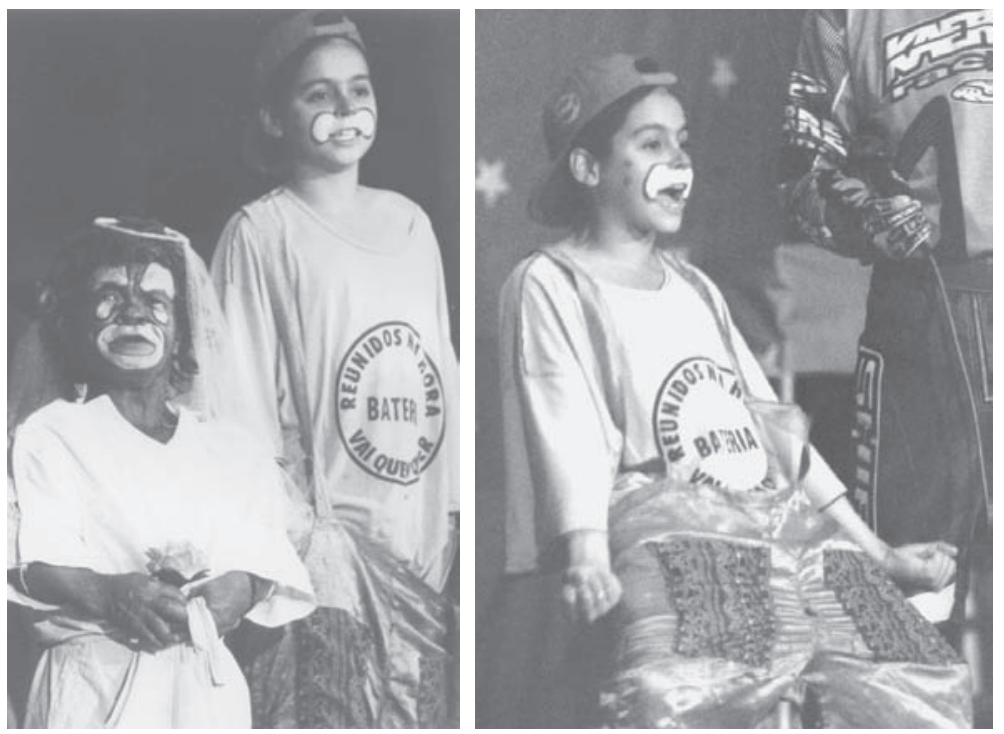

vo apelo a gestos sexuais. Sua indumentária era pouco elaborada. Nos três espetáculos assistidos, o macacão de estampas finas se repetiu. Camiseta e bonés, o mais simples possível, alternaram-se. A mesma camiseta que usava no cotidiano servia de figurino. A maquiagem, muito simples, repetiu-se.

A primeira aparição do Batatinha em cena resumiu-se, nos três espetáculos, a um pequeno jogo de piadas, acrescidos da reprise "A magia com patos". Na segunda, fazendo parceria com o anão CocaCola, predominou a entrada do "Fotógrafo", quando Coca-Cola era a noiva. Batatinha, entretanto, não se vestiu a caráter, ou seja, não se preocupou com um figurino que fizesse lembrar o papel de noivo, para o qual fora destacado. 



\section{6 \\ Garden Circo}

\section{O espetáculo}

Primeira parte: Giro; Dublagem da Tiazinha; Motoca em "A coisa mais forte do mundo"; Contorção; Dublagem; Babalu em "Poroite"; Corda indiana; Dublagem.

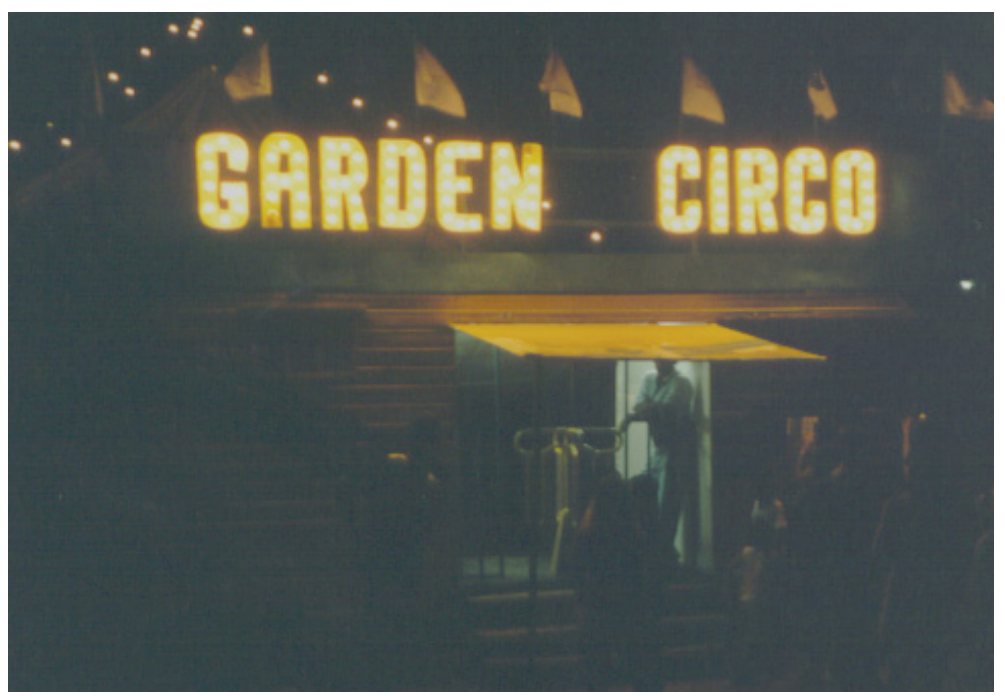


Segunda parte: Comédia, "O casamento do palhaço Babalu".

O Garden Circo foi visitado na cidade de Bayeux-PB, em 29 de dezembro de 1999. O Garden era pequeno, com dois mastros e aproximadamente 18 metros x 22 metros, nas cores vermelha e azul. Um conjunto de arquibancada, dupla na parte central e simples nas laterais, compunham o principal acomodamento da plateia. Uma pequena cerca de madeira separava a arquibancada das poucas cadeiras. No picadeiro, uma pequena esteira indicava a parte central onde se desenrolou o espetáculo. Uma cortina nova, de lona plástica, na mesma cor da lona de cobertura, com grandes listras, completava o cenário da casa de espetáculo. As luzes internas eram precárias.

\section{Motoca}

Acompanhando a tônica do espetáculo, o palhaço Motoca não apresentou uma performance que pudesse segurar o ímpeto do público. Aliás, com participação ruidosa, às vezes ofensiva aos artistas,

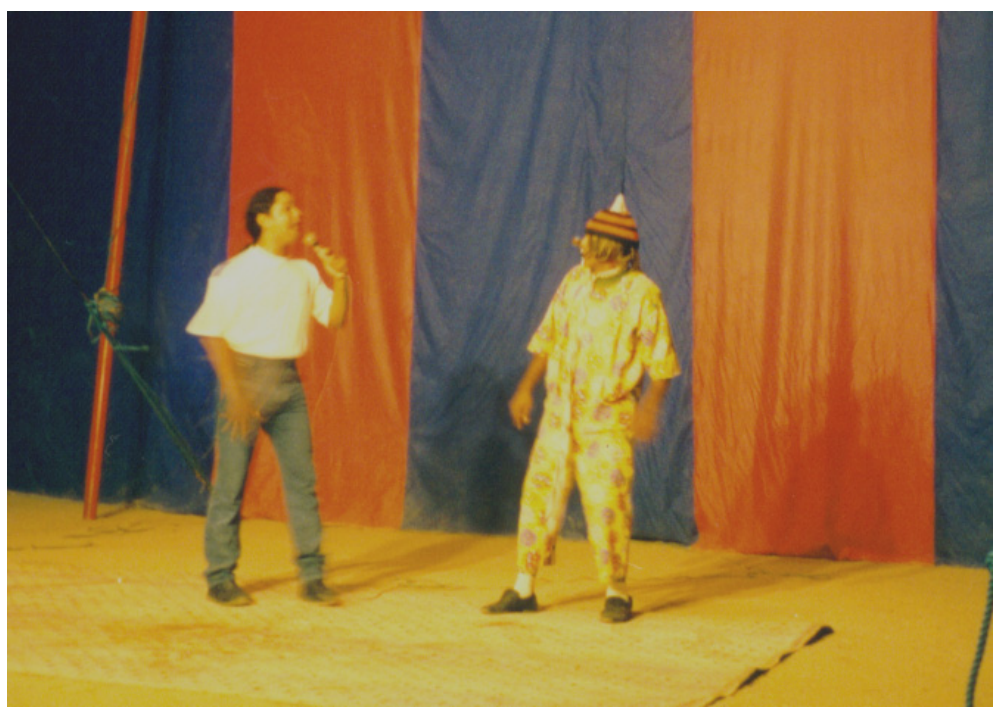


certos setores da plateia se sobressaíam ao espetáculo. O ruído intenso do público teve como resposta o uso do microfone, por parte dos cômicos, mesmo sendo um circo pequeno. Houve uma "competição" de ruídos, o que comprometeu bastante o espetáculo apresentado. Motoca não apresentou uma personagem característica. Fez do roteiro das entradas e de suas piadas a âncora necessária para o riso. Contudo, este aporte foi insuficiente, uma vez que a maioria deles e suas respectivas piadas são de conhecimento do público. Se o texto falado não vem acompanhado de uma performance convincente, não ocorre o efeito cômico. Motoca não conseguiu superar esse impasse.

\section{Babalu}

Babalu, por sua vez, apresentou um maior traquejo de picadeiro. Inicialmente alvoroçado, o público foi aos poucos sendo conquistado pelo palhaço. Sua performance foi bastante "apimentada", como ele mesmo afirmou, com alusões fálicas, tendo como suporte a gravata, o cabo de uma vassoura e até mesmo os dedos das mãos. A roupa vermelha e verde-escura não se destacava diante do predomínio vermelho/azul da cortina e da lona do circo.

Quando chegou o momento da comédia, o público estava um pouco mais contido, mas jamais quieto: a todo instante ocorriam intervenções variadas, às vezes dando motivo à improvisação, outras, querendo competir com os artistas. Babalu demonstrou dominar aquela prontidão necessária para manter a atenção do espectador.

\section{O casamento do Babalu}

Babalu, pai rigoroso e enérgico, tem uma filha. Um pretendente vai visitá-la. O pai faz tanto alarde antes de entrar em casa, que provoca pânico na filha e no namorado. Na primeira entrada, o moço se esconde sob a mesa e a filha diz ser o cachorro (improvisação em 

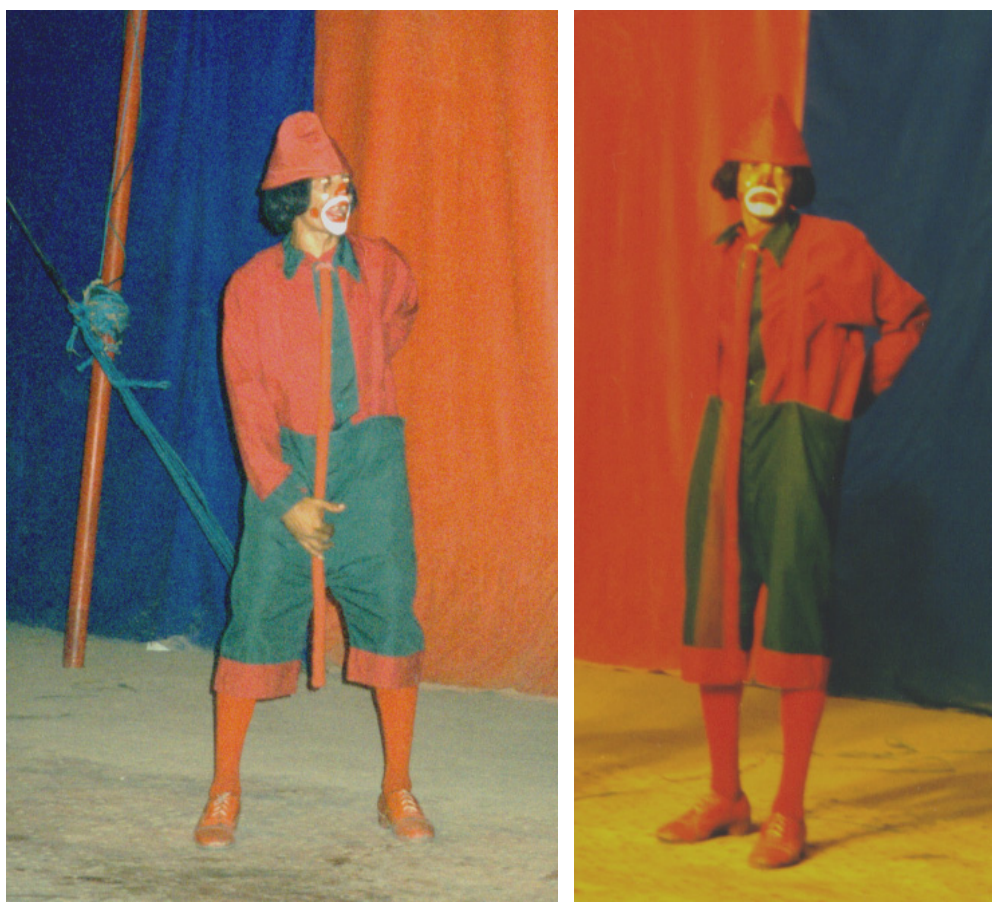

torno do cachorro). Na segunda, o moço transforma-se em santo, sendo coberto com a toalha da mesa. Novamente, improvisação em torno do santo, que se movia e provocava a desconfiança do pai. Depois, o namorado transforma-se em um rádio, coberto com o mesmo pano, cantando algumas canções e imitando a transmissão de um jogo de futebol. No quarto momento, o pretendente transforma-se em sombra do palhaço. Cena hilariante com uma refeição de farinha de mandioca. Finalmente, o moço acaba com todos os disfarces e revela suas intenções. O pai nega o casamento. Como Babalu é viúvo, o moço oferece-lhe a irmã em casamento: vão fazer um casamento coletivo. A irmã entra em cena, plenamente tipificada: velha, feia, debochada, desdentada, enfim, ridícula. A partir de então, a cena direciona-se ao convencimento para que Babalu se case com a irmã, composto de várias improvisações. Uma em particular chamou a atenção: Babalu interpreta um típico político populista, 
prometendo absurdos ao povo sofrido do lugar, como, por exemplo, acabar com o sol e com isso com o sofrimento do calor e da seca.

Ao final do espetáculo houve uma tentativa de conversa com Babalu. Seu nome: Marcos Miguel do Nascimento. Vinha da Bahia, juntamente com o circo. Homem fechado, de poucas palavras, completamente distante daquela espontaneidade apresentada no picadeiro. Não houve entrevista produtiva.

O primeiro espetáculo visto no Nordeste já expôs uma característica dos circos da região: geralmente as companhias são compostas de mais de um palhaço. Raríssimas vezes eles trabalham em conjunto. Como há uma preferência por entradas faladas, os palhaços apresentam-se com um mestre de pista. Além disso, os primeiros palhaços que se apresentam são, em geral, os mais fracos. O palhaço principal da companhia tem sua aparição na parte final do espetáculo. 



\section{7 \\ Circo Gitano}

\section{O espetáculo}

Adagas; Tutuca em "Cidade de trás pra frente"; Dublagem; Trapézio em Balanço; Malabares; Dublagem parodiada, com Tutuca; Dança - Rumba; Biliscada e Tutuca em "O caveirão"; Dublagem - Madona do Nordeste; Arame bambo; Bombinha em "Abelha, abelhinha"; Escada giratória.

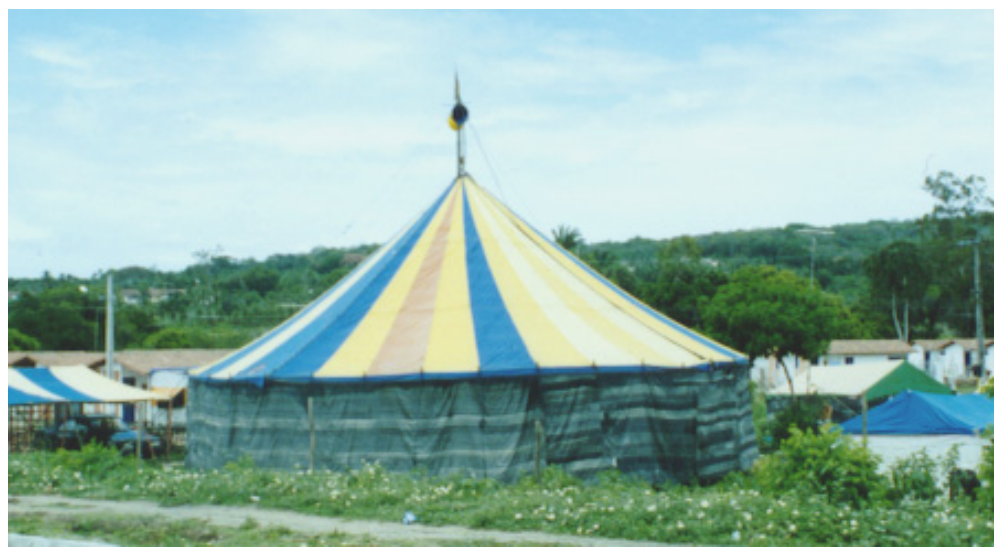




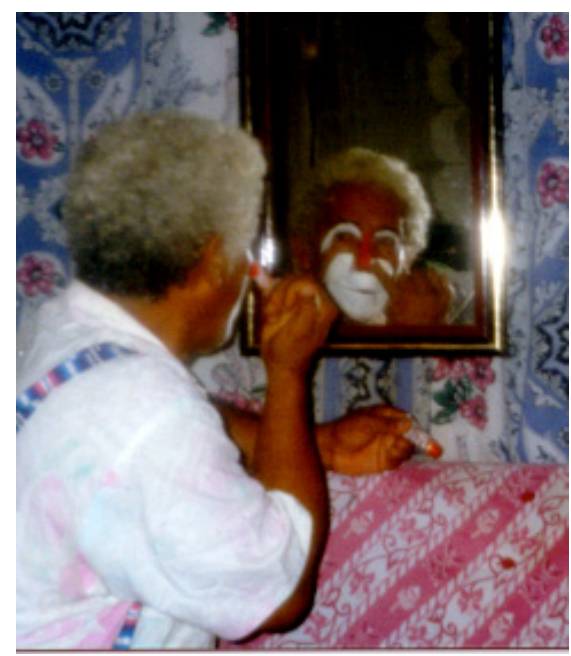

\section{Tutuca}

Walace Ferreira Viana, o Tutuca (abaixo, à direita), tinha 14 anos. Filho do proprietário, Biliscada, ele era simpático no picadeiro e, em pleno aprendizado, ainda estava apegado a gestos corriqueiros e à piada prevista no roteiro das entradas. A roupa, bastante colorida, contrastava com o fundo negro da cortina. Deslocou-se muito pouco pelo picadeiro e ainda não possuía o tempo cômico devidamente assentado. Interagia precariamente com o público e não trabalhou o congelamento dos gestos. Sua voz, contudo, era bem projetada. Havia, no entanto, um contraste entre o tipo "esperto" que aparentava ser e o raciocínio lento que a entrada, "Cidade de trás pra frente", requer. Além de palhaço, Walace participou do espetáculo como aramista e também integrou a equipe da escada giratória.

\section{Bombinha}

Neubis Bezerra de Assis (abaixo, à esquerda), além de apresentar-se como malabarista e atirador de facas, também participou do 


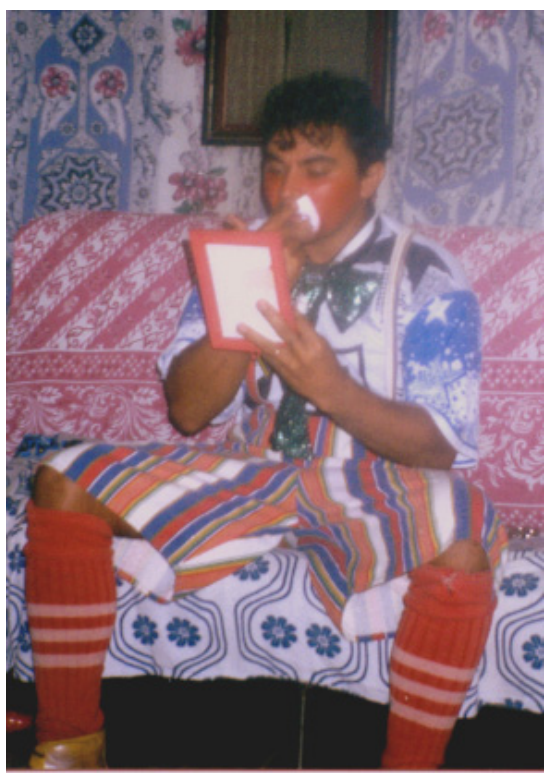

espetáculo como palhaço. Sua vestimenta era modesta: camisa estampada, gravata cintilante, macacão pequeno listrado, meias longas e sapatos simples. Participou da "Abelha, abelhinha". Se não possuía qualidades exuberantes de cômico, ao menos foi eficiente nos poucos recursos que manipulou, como por exemplo a cadência rítmica da graça. Não se pode dizer que tivesse conhecimento técnico do domínio e interação com o público, mas, em compensação, não se apegou a recursos de "riso garantido", tais como a exploração de gestos e falas obscenas. Aliás, todas as três apresentações dos palhaços primaram pela ausência de recursos fáceis, de apelo a temas e gestos explicitamente sexuais. Quando esteve presente, o que se viu foi a exploração do duplo sentido.

\section{Biliscada}

O proprietário do circo, Roberto Ferreira Viana, interpretou o palhaço Biliscada (acima). Sua performance foi depurada, sintética, 
194 MARIO FERNANDO BOLOGNESI

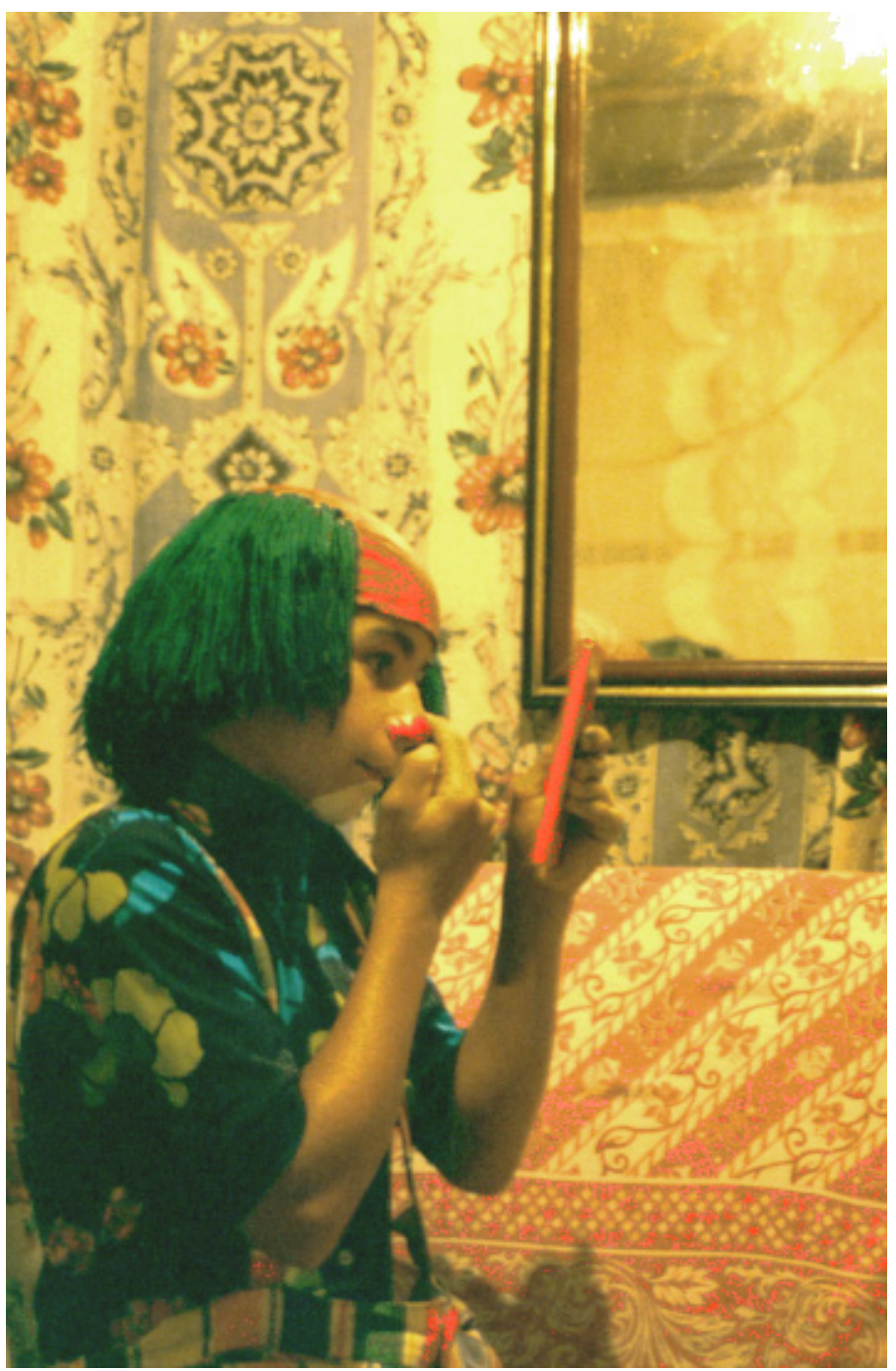



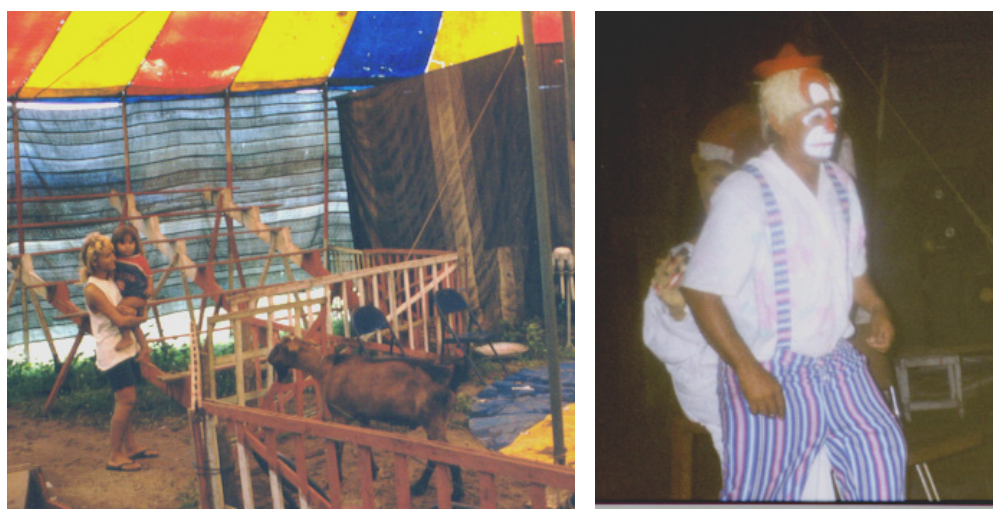

com gestos trabalhados adequadamente para o objetivo cômico. As roupas eram simples, compostas de uma camisa não muito larga e de um macacão listrado e curto. Os sapatos eram desproporcionais, típicos do Augusto. A maquiagem acompanhava os traços clássicos do palhaço, com peruca e rosto ampliado. Um pequeno chapéu evidenciava a cabeça enorme. Este tipo de maquiagem, no geral, "esconde" o homem para "revelar" o artista e sua personagem. Participou com Tutuca de "O caveirão". A cada ação do fantasma, ele paralisava o gesto e buscava uma expressão facial precisa que, para o caso em questão, deve transparecer dubiedade: mostrava o medo e, ao mesmo tempo, alardeava coragem. 



\section{8 \\ POP CIRCO}

\section{O espetáculo}

Primeira parte: Arame; Espigão em "A natureza"; Dublagem; Faísca e Espigão em "O piano"; Dublagem; Perlotinha em "Dói-dói”; Dublagem; Paródia dublada - Gal de Costas.

Segunda parte: Corda indiana; Magia; Táxi Maluco, com os três cômicos.

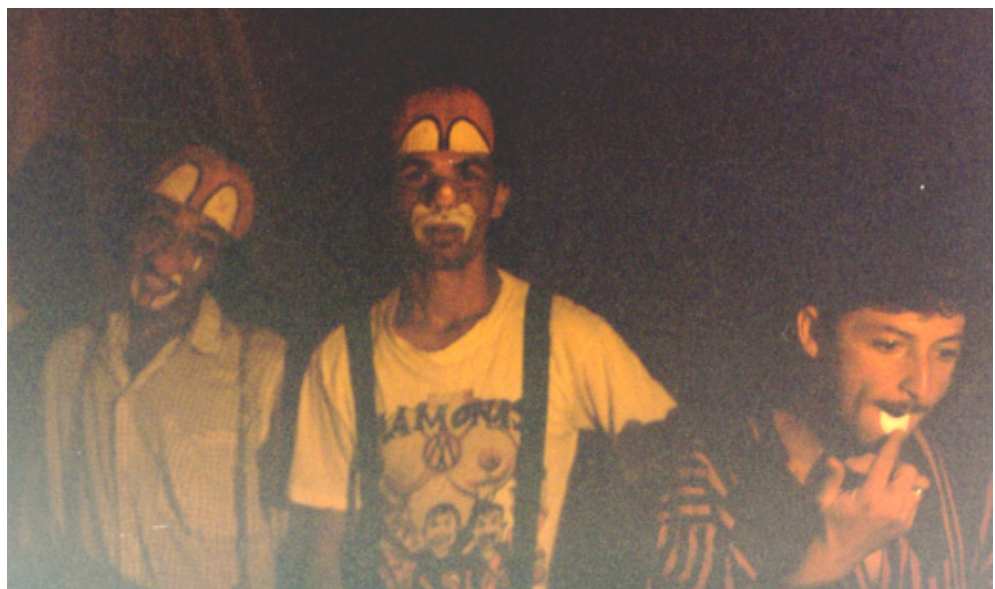




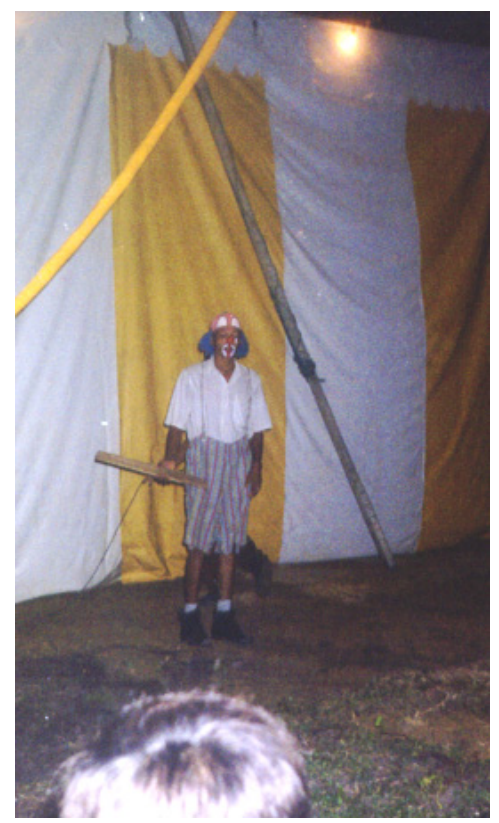

O Pop Circo, instalado em Baía da Traição-PB, previa sua estreia para dia 7 de janeiro de 2000. Ela foi, no entanto, adiada porque o trabalho de recuperação da lona, a costura de pequenos rasgos, o tapar buracos e o conserto de trechos de palomba não conseguiram ser terminados a tempo. A estreia ficou adiada para o dia seguinte, sábado, 8 de janeiro.

$\mathrm{O}$ circo era pequeno, de dois mastros, com uma lona com boa aparência, nas cores amarela e azul, medindo 18 metros x 26 metros. O público acomodava-se em arquibancadas simples e em duas dúzias de cadeiras, separadas por uma cerca de madeira. Uma cortina vistosa, nas mesmas cores da cobertura, dividia a área de espetáculo dos bastidores. Não havia demarcação de picadeiro, nem ao menos um tapete. As apresentações ocorriam diretamente no chão.

O espetáculo tinha poucos números, excesso de dublagens e um trio de cômicos. Cada um dos palhaços teve uma participação no espetáculo, quase sempre em entradas, e seu partner nem sempre era outro palhaço. Havia, também, uma certa hierarquia de impor- 
tância (e também de qualidade) entre os palhaços. O melhor palhaço participou do espetáculo na última entrada.

\section{Espigão, Faísca e Perlotinha}

Espigão e Faísca não tinham uma marca definida de palhaço: vestiam-se, maquiavam-se, mas não apresentaram uma caracterização particular. Perlotinha, por sua vez, foi um pouco mais apurado na roupa, nos sapatos e na maquiagem. Trabalhou os gestos com um pouco mais de preocupação. Mas, no geral, todos eles se apegaram à graça que advém do roteiro, da piada prevista para o final. Espigão mostrou seu melhor desempenho nos números de paródia, Gal de Costas, e no Táxi Maluco. Em ambos, apresentando-se travestido - no primeiro, de mulher; no segundo, de homossexual , o artista demonstrou o seu potencial de ator, assumindo plenamente suas personagens, desafiando as observações insinuantes da plateia, sem deixar a personagem de lado. $\mathrm{O}$ mesmo empenho não se deu quando se apresentou como palhaço. 



\section{9 \\ Circo Raniere}

\section{O espetáculo}

Primeira parte: Bailado; Trapézio em Balanço; Dublagem; Bailado, com cantora e baterista; Dublagem; Rola-rola; Xuxu em "O filho pródigo"; Dublagem; Bailado; Dublagem; Pirulito em "Cidade de trás pra frente" e "A natureza".

Segunda parte: Cantor Adriano Freitas, da localidade.

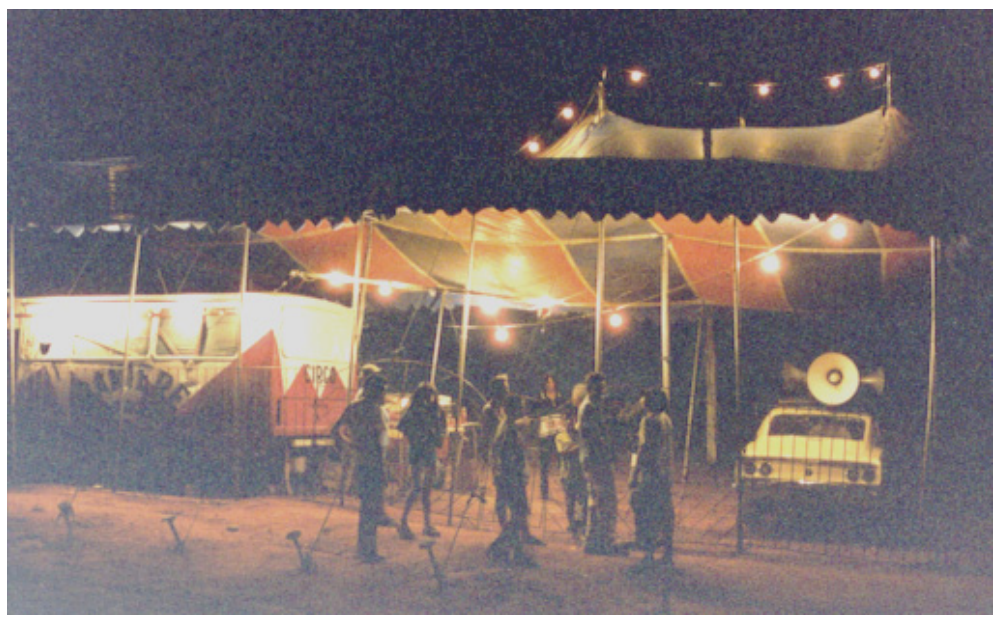




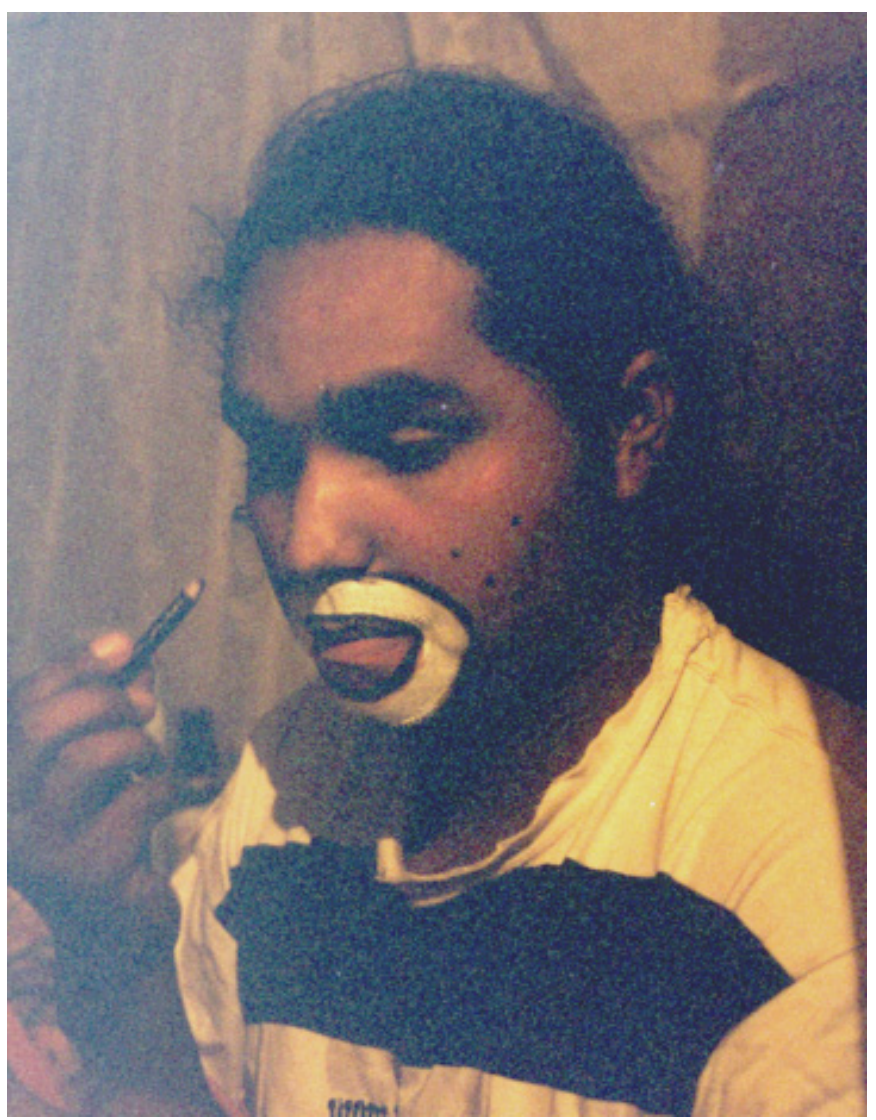

O Circo Raniere foi encontrado no distrito de Rafael, município de Caruaru-PE, em 10 de janeiro de 2000. Era um circo médio, de 28 metros x 36 metros, nas cores azul e vermelha, tanto o pano de cobertura como a cortina. O espaço de espetáculo era composto por um palco de 8 metros de boca e 6 metros de profundidade. A iluminação era muito fraca, o que comprometeu a qualidade das fotografias. O público acomodava-se em uma ampla arquibancada, separada das cadeiras por uma cerca de ferro. O espetáculo do Circo Raniere foi quase que totalmente composto de números de dublagens, com as cinco garotas do circo. Números circenses foram apenas dois: Trapézio em Balanço e Rola-rola. 
Os palhaços da companhia eram o Xuxu (José Evaristo da Silva, 58 anos, na época, e palhaço desde os 13) e Pirulito (José Ronaldo Evaristo da Silva, tinha 22 anos, atuando como palhaço desde os 6). Xuxu fez um tipo matuto, retardado e às vezes esperto. Em sua roupa predominava o tom vermelho. Pirulito apresentou um tipo próximo de um moleque, com raciocínio lento. Eles exploravam predominantemente a graça das piadas faladas, com expressões corporais sem muita elaboração. 



\section{0 \\ Circo Mágico Alakazan II}

Em São Lourenço da Mata, no Grande Recife, estava o Circo Mágico Alakazan II, visitado em 12 de janeiro de 2000. Ele estava montado em um bairro próximo ao centro. Era um circo de 30 metros, de um mastro apenas, com a lona bastante avariada. A estrutura era extremamente precária. O circo estava montado, mas não estava apresentando espetáculos. Segundo informações de um funcionário, única pessoa no circo, não havia previsão de retorno das apresentações.

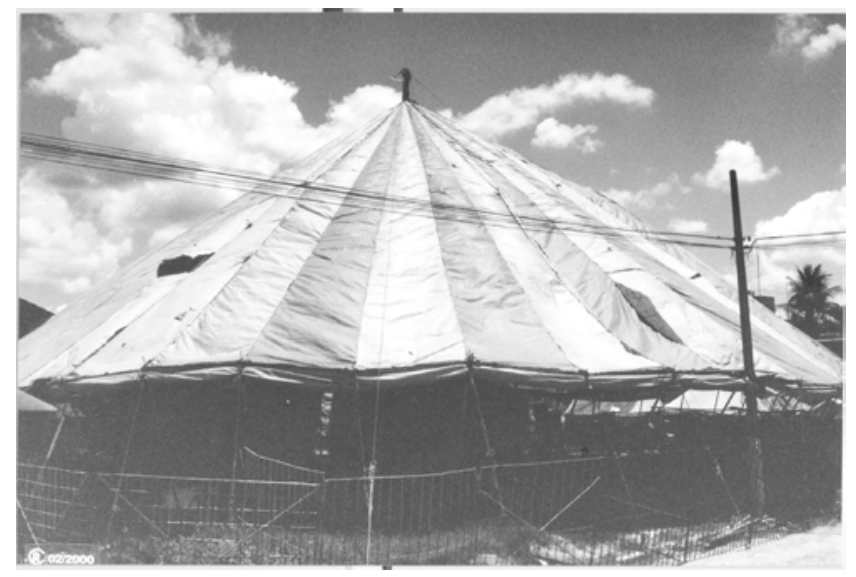





\section{1 \\ Circo Washington}

\section{O espetáculo}

Primeira parte: Bailado; Cesto; Lira; Fuxico e Gostosinho em "Poroite"; Arame alto; Dublagem cômica - Pau de sebo e Risoleta; Balé Aéreo; Salsicha em "Sonâmbula"; Rola-rola; Dublagem cô-

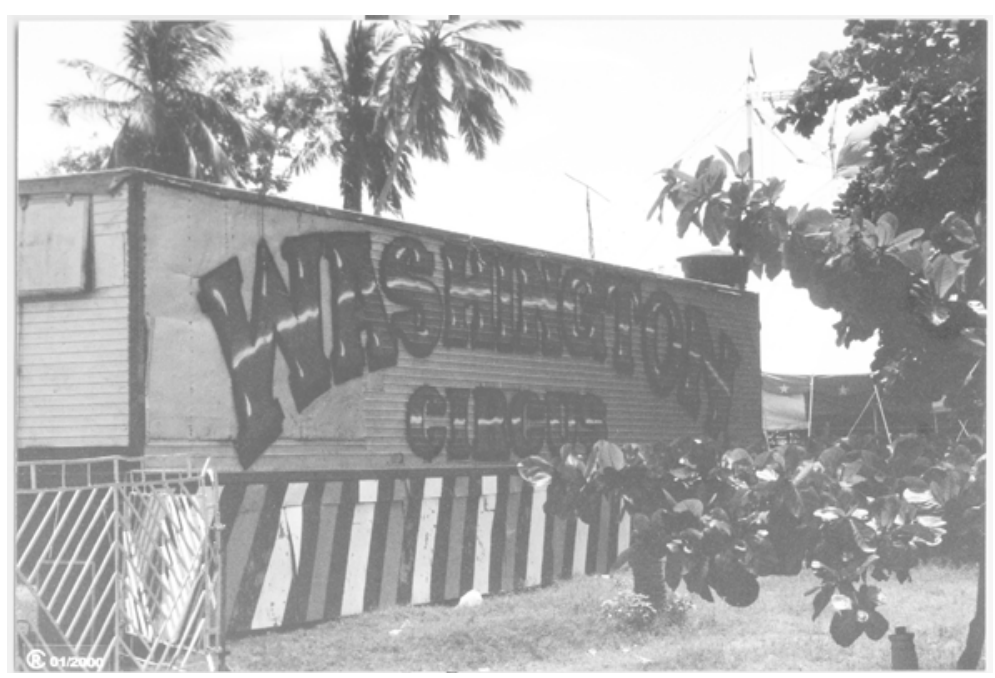




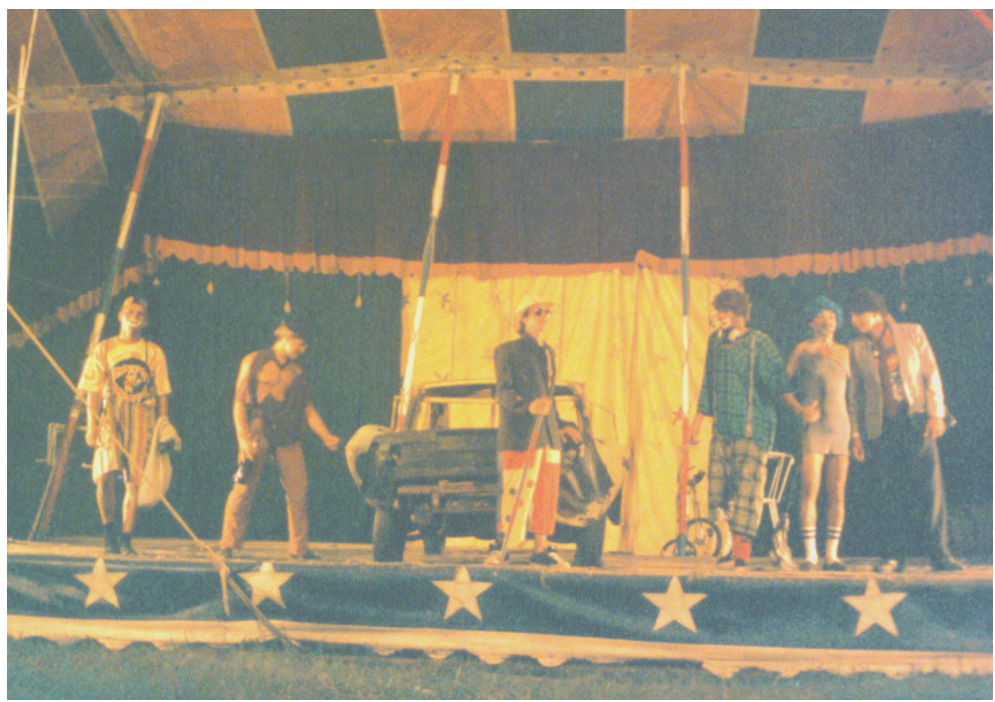

mica - Gostosinho; Cão amestrado; Sukita em "O filho pródigo"; Pêndulo.

Segunda parte: Trapézio Voador e Táxi Maluco.

São José da Coroa Grande é um município litorâneo, ao sul do Estado de Pernambuco, divisa com Alagoas. O Circo Washington estava montado no centro da cidade. A companhia foi visitada nos dias 13 e 14 de janeiro de 2000.

O circo era grande, de quatro mastros e cúpula, com aproximadamente 50 metros x 60 metros de área interna. A lona era azul e vermelha, com tempo razoável de vida. A frente do circo era fechada pelas carretas de transporte, com desenhos com temática circense. A entrada do público dava-se por uma escada, passando pelo interior de uma dessas carretas. Ao descer, o espectador encontrava uma praça de alimentação.

O espaço interno era composto por arquibancadas, setor de cadeiras e camarotes. Um grande palco abrigava os principais números do circo. Uma primeira cortina verde-escura, recoberta por um babado bordô, separava o espaço de cena dos fundos do circo. Quan- 

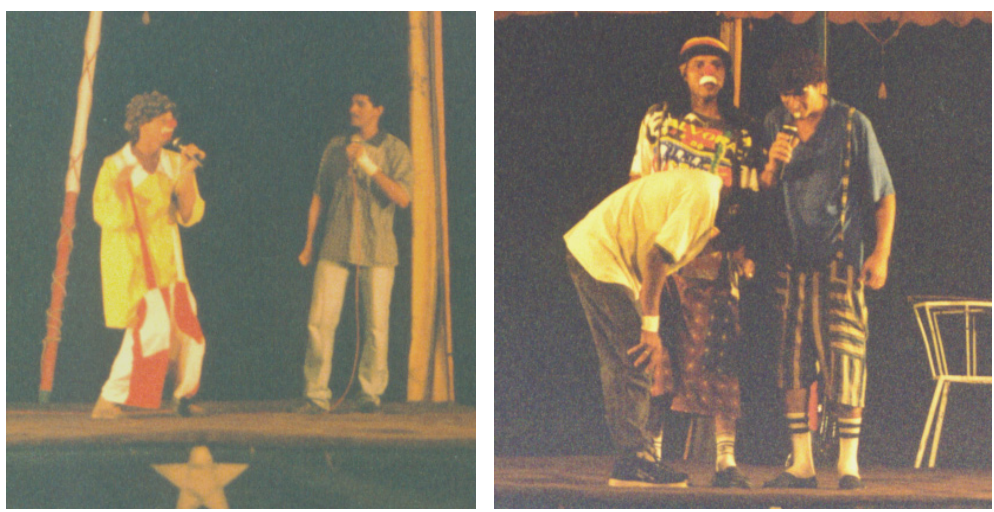

do ela se abriu, uma outra, amarela com muitas estrelas, amenizava o tom escuro do palco. À frente do palco, um grande espaço "vazio" (que coincidia com a cúpula da lona) estava a descoberto. Caberia um bom picadeiro, mas servia apenas como lugar de passagem aos artistas que tinham seus aparelhos e números montados sob a referida cúpula. Os palhaços, inclusive, pouco exploraram esse espaço, o que daria uma aproximação maior com o público. O circo não possuía recursos de efeitos luminosos, mas a luz geral branca era suficiente. A estrutura administrativa da companhia era predominantemente familiar. Programado para as 21 horas, o espetáculo atrasou 35 minutos.

Os palhaços do Circo Washington eram bastante versáteis. As reprises e entradas que levaram são conhecidas: "Poroite", "O filho pródigo" e "Sonâmbula". Foram, contudo, executadas com apuro. Os palhaços participaram em outros momentos do espetáculo, especialmente Gostosinho, em dublagens. Todos eles estavam envolvidos na apresentação do Táxi Maluco.

Todos os palhaços eram da mesma família: Gostosinho era Wilson Barros Silva; Fuxico, seu tio, Wilson Silva; Welington Barros Silva, o Salsicha, irmão de Gostosinho, tinha, na época, 36 anos de idade. Trabalhava como palhaço desde os 15 anos; Sukita, Washington Barros Silva, irmão de Wilson e Welington, seguia os passos estilísticos do irmão mais velho, Salsicha. 


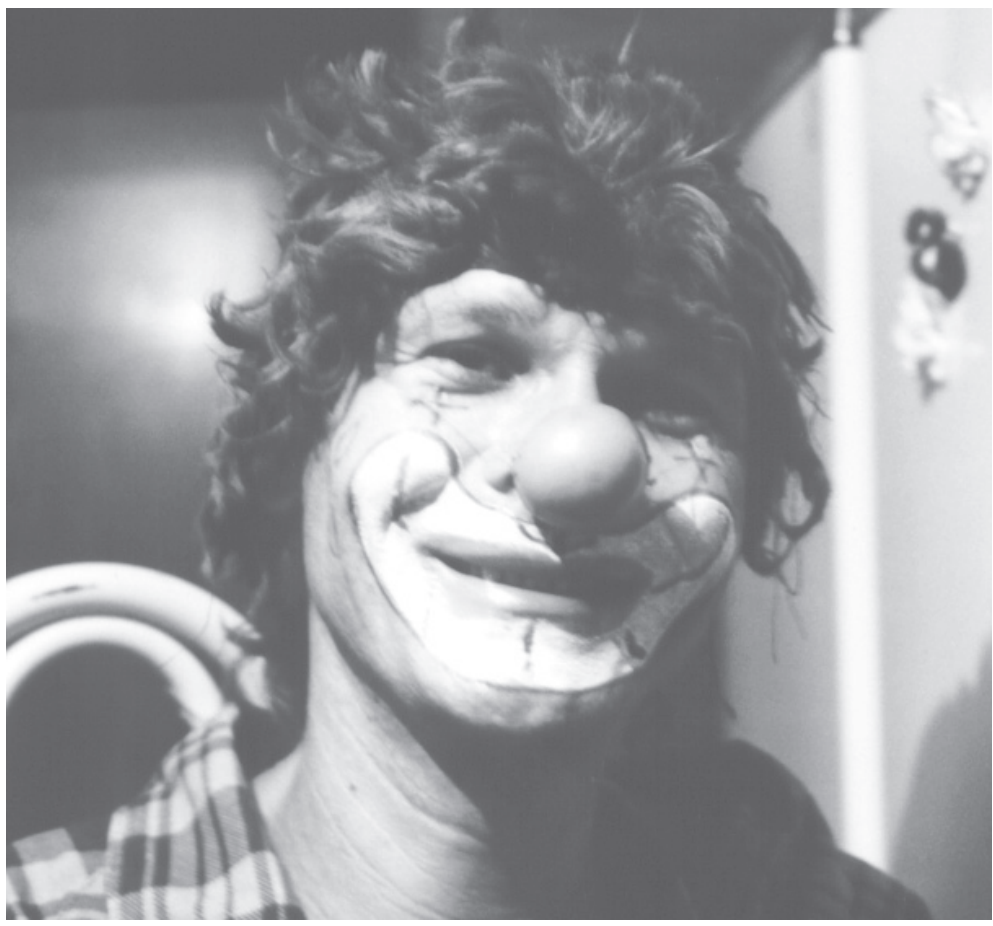

\section{Salsicha}

Salsicha (à esquerda) foi o palhaço da companhia que apresentou a melhor performance. Trabalhou a personagem de forma completa, procurando a devida adequação entre gesto, roupas e voz. Salsicha era um moleque abobalhado, de raciocínio lento, medroso e sem jeito. Foi, evidentemente, inspirado na personagem homônima televisiva que atua no desenho animado Scooby Doo. Em nenhum momento, ele se desfez da personagem. Ele trabalhou o repertório de acordo com sua caracterização. Para tanto, fez as devidas adaptações do roteiro ao tipo eleito.

O principal limite em sua atuação foi dado pela necessidade de uso do microfone, que terminou inibindo o desempenho corporal. Esse é, contudo, um costume nos circos nordestinos, mesmo nos 


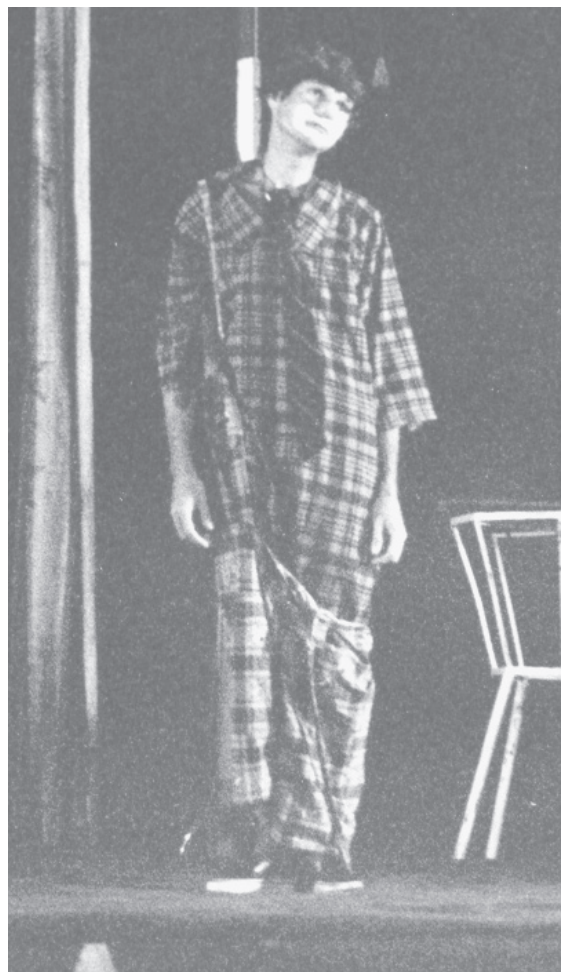

pequenos. Salsicha tinham plena consciência disso. Em suas palavras, justificou o uso do aparelho tendo em vista a atitude ruidosa do público circense do Nordeste. O domínio do público por meio do microfone induziu a uma expectativa de silêncio da plateia. Isso, certamente, terminou constrangendo aquilo que, no circo, diferencia a relação da cena com o público, ou seja, o constante diálogo e interferência mútua de um com o outro. $\mathrm{O}$ público incentiva e abusa da atuação do palhaço. Ele cria situações a cada instante, o que estimula o desempenho descontraído e improvisado do palhaço. A participação da plateia na atuação do palhaço, que é apontada por muitos artistas como essencial à arte cômica do picadeiro, terminou intimidada pela força da reprodução eletrônica da voz. Nos circos do Nordeste, a voz se sobrepunha ao corpo, sendo o principal elemento da ação cômica. 



\section{2 \\ Circo de Las Vegas}

\section{O espetáculo}

Primeira parte: Pratos bailarinos; Parada de cabeça no trapézio; Cheirosinho em "Cidade de trás pra frente"; Corda; Dublagem; Tranca; Gostosinho em "A flor maravilhosa".

Segunda parte: Dublagem com o palhaço Cheirosinho; Escada japonesa; Táxi Maluco.

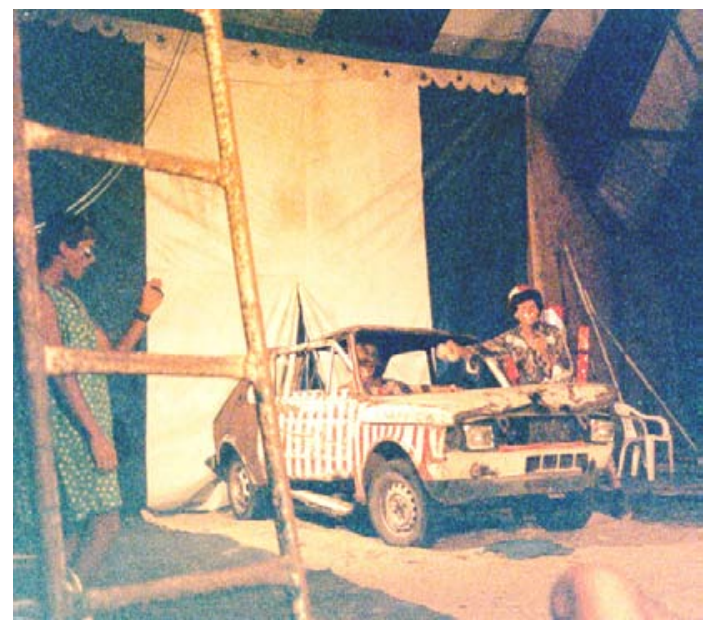



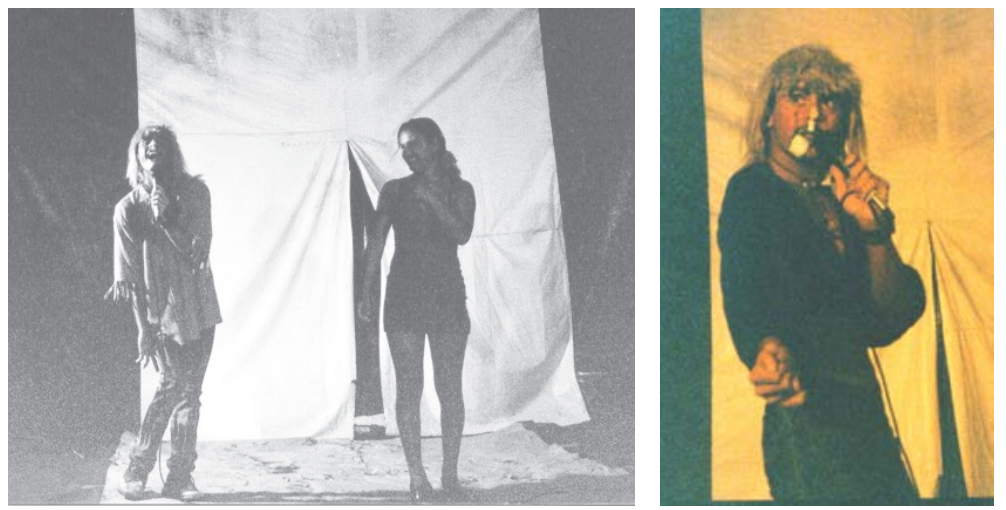

O Circo de Las Vegas era pequeno, de dois mastros, com aproximadamente 22 metros x 30 metros. A lona azul e branca era nova, porém com um grande rasgo, em função de ventos fortes na localidade de Serrambi, município de Ipojuca-PE, ocorridos no início de janeiro de 2000. O público acomodava-se em algumas cadeiras e em arquibancadas. Um tapete surrado demarcava o espaço do picadeiro. A iluminação era fraca. O espetáculo foi visto em 15 de janeiro de 2000 .

A companhia era familiar. Os números apresentados diferiam dos habituais. A família tinha tradição em números de Tranca e Escada japonesa (escada equilibrada sobre os pés, com um volante fazendo evoluções a toda altura). O espetáculo apresentou, também, paradas de cabeça em trapézio (parado, em balanço e, finalizando, com o trapézio girando).

\section{Cheirosinho e Gostosinho}

Os palhaços Cheirosinho (Robson Melo da Silva, na época com 18 anos) e Gostosinho (Kildo Brandão, 22 anos) eram parecidos, tanto na vestimenta como no modo de atuar. Diferiam, no entanto, na maquiagem. Cheirosinho tinha o queixo branco, pintado perpendicularmente; Gostosinho trazia o branco apenas no bigode. Em cena, 
resumiam-se a buscar o riso a partir das piadas contadas. Havia pouca gesticulação e quase nenhum trabalho corporal. Ambos tinham um bom carisma com o público.

Gostosinho protagonizou o número de paradas de cabeça sobre o trapézio. No Táxi Maluco, Cheirosinho interpretou um homossexual.

\section{Linguiça}

O palhaço Linguiça (Cleber Silva Brandão, na época com 38 anos) era o proprietário do circo. Durante o espetáculo atuou como Apresentador quase que todo o tempo. Maquiou-se para participar do Táxi Maluco, na função de motorista. Apresentou uma característica peculiar, trabalhada de acordo com a personagem. Era muito lento ao falar, com os gestos acompanhando o mesmo ritmo, induzindo a morosidade do raciocínio. O rosto e o corpo acompanhavam essa característica da personagem. Infelizmente, ele não participou do espetáculo em entradas ou reprises. 



\section{3 \\ Circo Pallesty Itália}

\section{O espetáculo}

Corda indiana; Cães amestrados; Dublagem; Birrinha em "Morrer pra ganhar dinheiro"; Rola-rola; Dublagem; Contorção; Birrinha em "O beijo no escuro"; Chicotes; Dublagem; Monociclo; Paródias e dublagens.

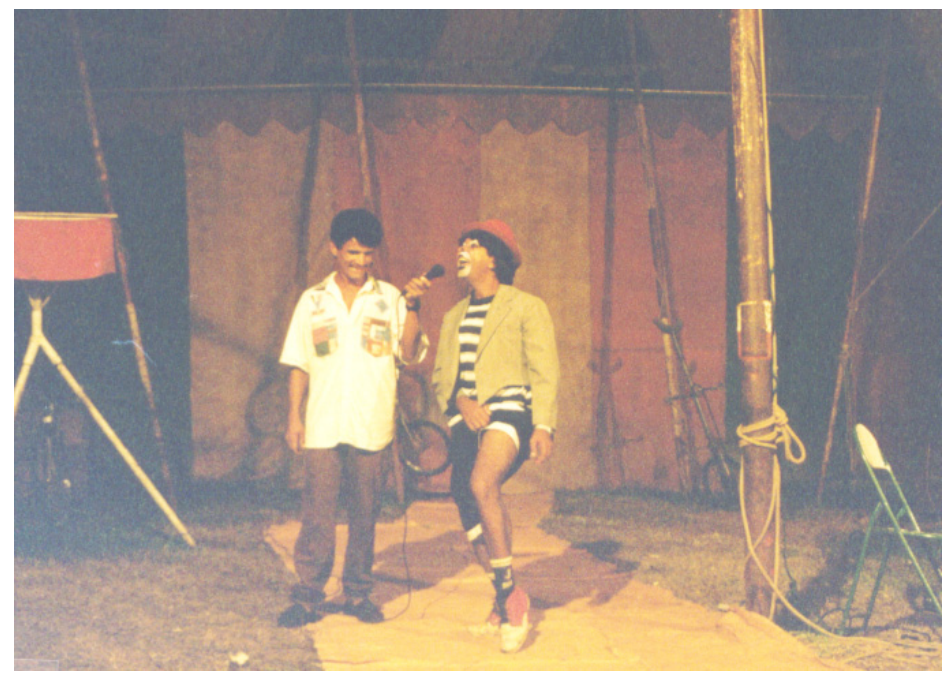


O Circo Pallesty Itália, de um mastro apenas, tinha 30 metros de diâmetro. A lona era azul e amarela. Um tapete amarelo, surrado, estendido desde o limite da cortina até as proximidades das cadeiras, servia de espaço cênico. As poucas cadeiras estavam separadas da arquibancada por uma cerca de madeira, sem pintura. O espetáculo foi visto e fotografado no dia 17 de janeiro de 2000, em Porto Calvo-AL.

Ao entrar no recinto, antes do início do espetáculo, notava-se um grande número de aparelhos, todos bem-dispostos e bem aparentados, ainda que simples na pintura e nos arranjos. A iluminação era bastante precária.

Apesar de modesto, o Circo Pallesty Itália tinha um bom espetáculo, com grande variedade de números. Desde o momento em que adentravam ao espaço cênico, os artistas tinham uma postura elegante: estavam sempre sorrindo, com um gestual leve e com constantes agradecimentos à plateia.

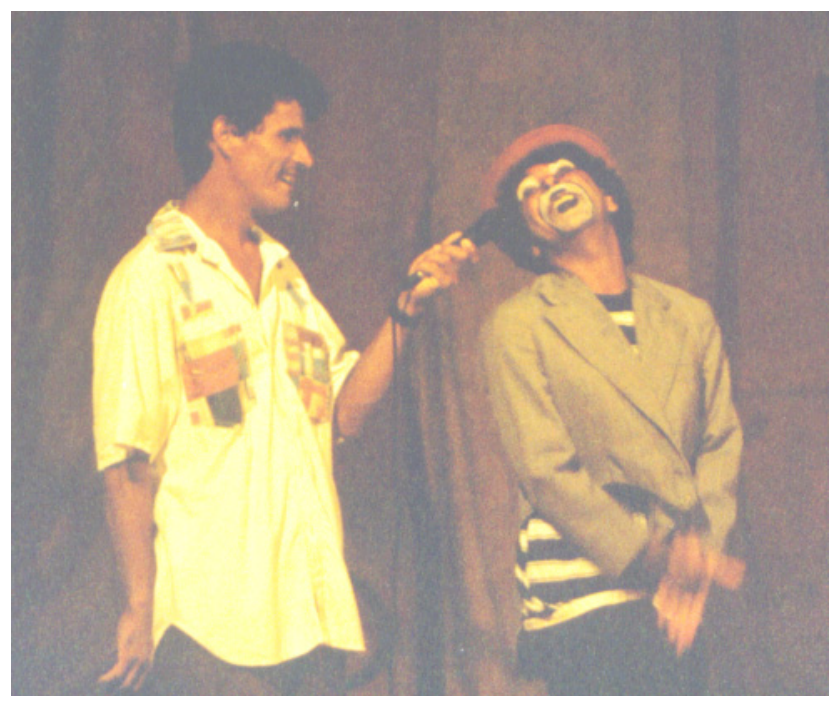




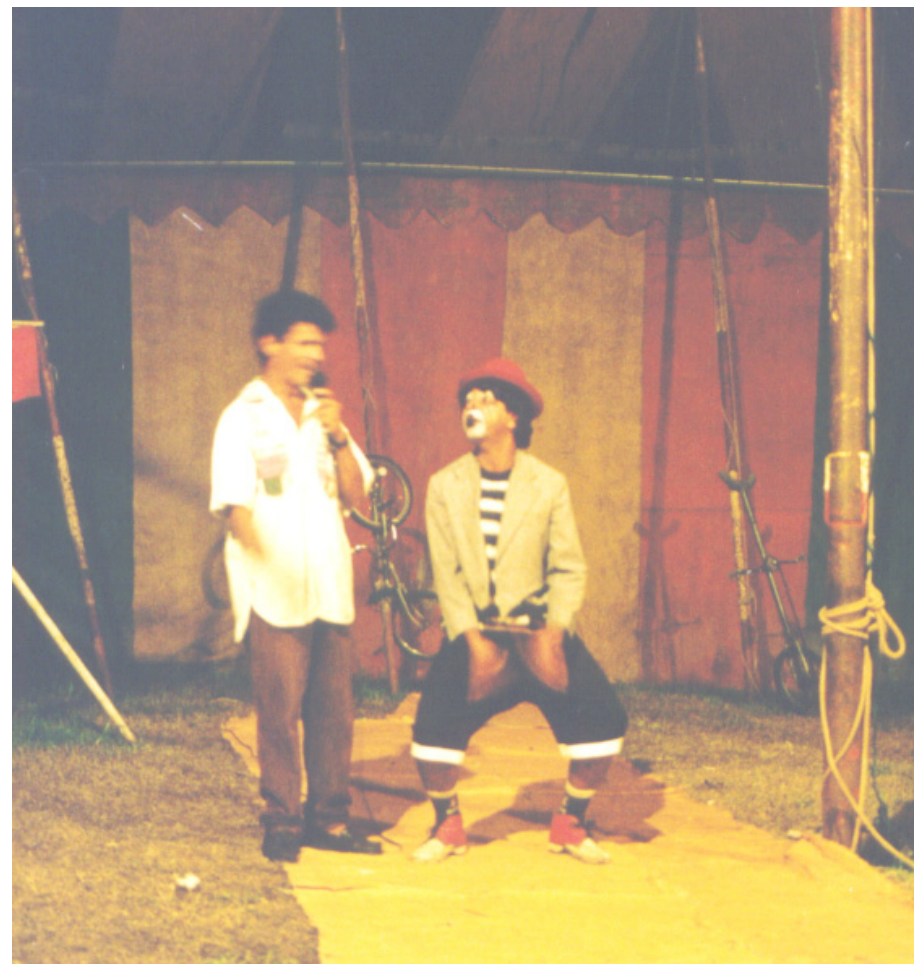

\section{Birrinha}

José Carlos da Silva, o Birrinha, na época contava 46 anos. Trabalhava como palhaço desde os 9 anos de idade. Era bastante discreto, contido e, às vezes, tímido. Movimentava-se pouco e concentrava-se mais nas piadas com as correspondentes expressões faciais. $\mathrm{O}$ limite do gesto estava diretamente ligado à imposição do microfone. A roupa era simples, nas tonalidades branca e preta. Da maquiagem, ressaltavam os lábios pretos, que se sobressaíam nas expressões do rosto. Participou das entradas "Morrer pra ganhar dinheiro", antecedida da "Disputa dos santos", e do "Beijo no escuro". Conseguiu conter a euforia do público sem apelo algum a obscenidades, tanto gestual como as de texto. Explorou o duplo sentido das falas e gestos. 



\section{4 \\ Circo Real Bandeirantes}

\section{O espetáculo}

Monociclo; Dublagem; Dublagem cômica; Arame bambo; Fogo; Dublagem; Equilíbrio; Dublagem; Caçolão em "O jornal”; Dublagem; Chocolate em "O morto que não morreu”.

O Circo Real Bandeirantes estava em Marechal Deodoro-AL. O circo possuía um mastro apenas, para uma lona de 22 metros de cir-

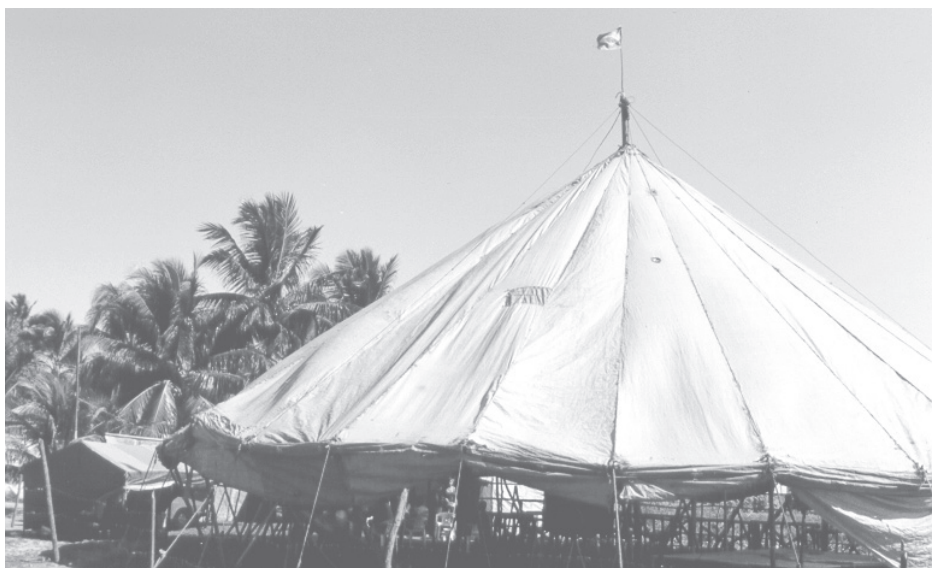


cunferência. A lona era velha e apresentava muitos furos. No interior, uma cerca de madeira dividia a pequena arquibancada das nove cadeiras que a companhia possuía. Um pequeno palco de três metros de boca, por dois de profundidade, era o principal espaço de apresentação. Com muita frequência, os artistas desciam do palco e ocupavam o chão em torno do mastro, próximo às cadeiras. Os aparelhos se destacavam pela precariedade. $\mathrm{O}$ arame bambo estava fixado por duas cruzetas de paus, com dois metros de altura. $\mathrm{O}$ artista que equilibrava objetos no queixo fazia uso de uma cruz de pau de lenha: um menino da plateia sentou-se na cruz e o artista equilibrou-os.

A precariedade do circo e dos aparelhos estava também presente na roupa e na performance dos artistas. Muitos deles apresentaramse com suas roupas cotidianas, surradas, com chinelos de dedos. Apenas as mulheres se maquiaram e, mesmo assim, com uma base apenas.

O espetáculo tinha excesso de números de dublagens. As moças abandonaram o palco, em direção à plateia. Lá, sentaram-se no colo dos espectadores, incitando-os a uma dança erótica. O Circo Real Bandeirantes colocou em cena, para dublagem, um homossexual do lugar, conhecido de todos, sem a menor noção de ritmo e de palco.

\section{Chocolate}

Washington Júnior, o Chocolate (à esquerda e, abaixo, no monociclo), tinha 18 anos de idade e se apresentava como palhaço desde os 10. Sua roupa era um macacão estampado e desbotado. Maquiagem simples. Usava sapatos grandes, feitos por ele mesmo com um pedaço de madeira (sarrafo), recoberto por um pano preto. Além de explorar o riso das falas, Chocolate esboçava um gestual mais trabalhado, procurando adequar-se ao texto. Participou do espetáculo nos números de monociclo e do equilíbrio sobre o queixo. 
CIRCOS E PALHAÇOS BRASILEIROS 223
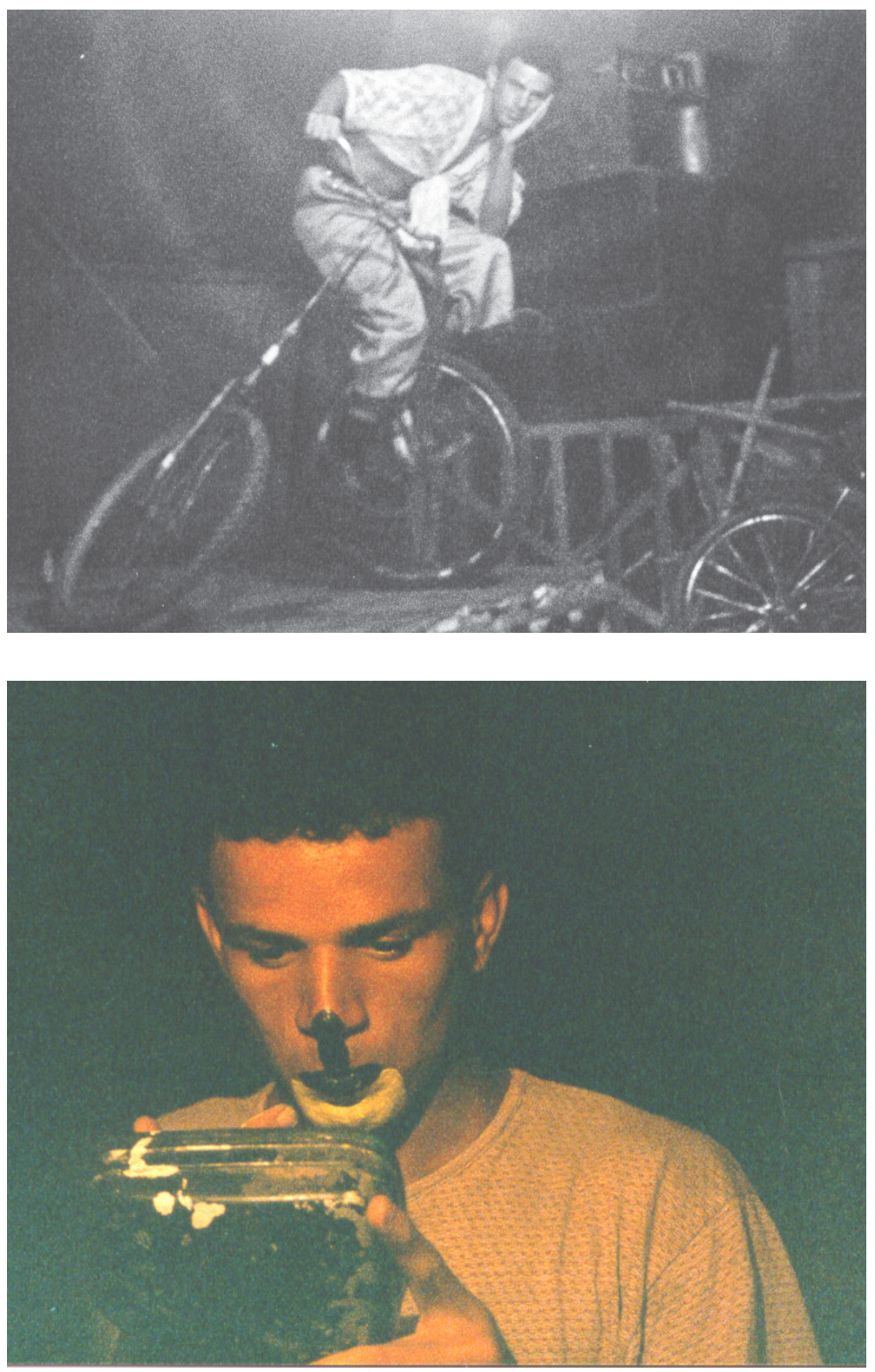


\section{Caçolão}

André Valentim dos Santos, o Caçolão (à direita), tinha 20 anos de idade. Ele iniciara na arte do palhaço havia um ano. Sua caracterização apresentava traços interessantes. $\mathrm{O}$ nariz era alongado e esverdeado. A roupa e a maquiagem acompanhavam a tonalidade verde, permanecendo, contudo, a precariedade da vestimenta. No geral, apegava-se - como a maioria dos palhaços vistos no Nordeste - na graça que advém da piada falada. Além de palhaço, André entrou no espetáculo no número de fogo e ainda acompanhou os outros palhaços nas entradas. Ele encenou "O jornal", diferente daquela já conhecida: vai rasgando aos poucos o jornal, lendo-o por partes,

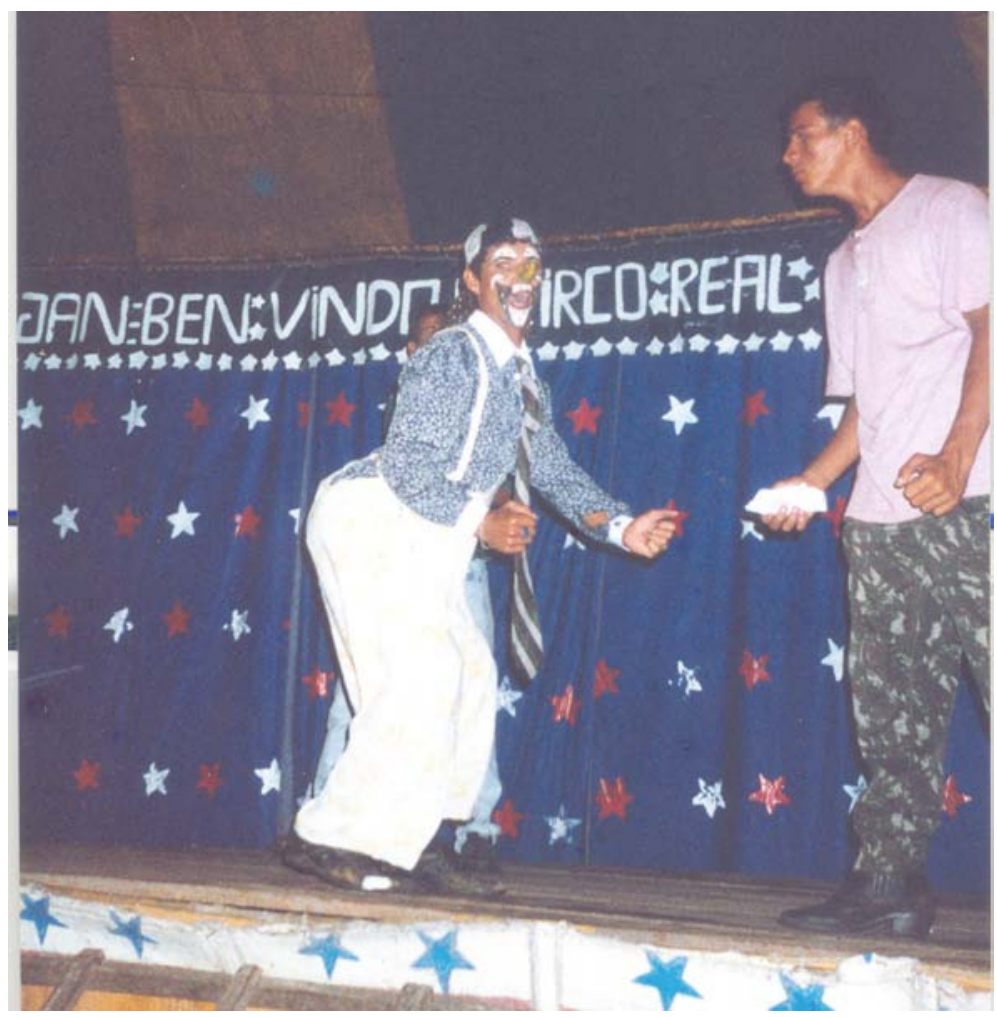




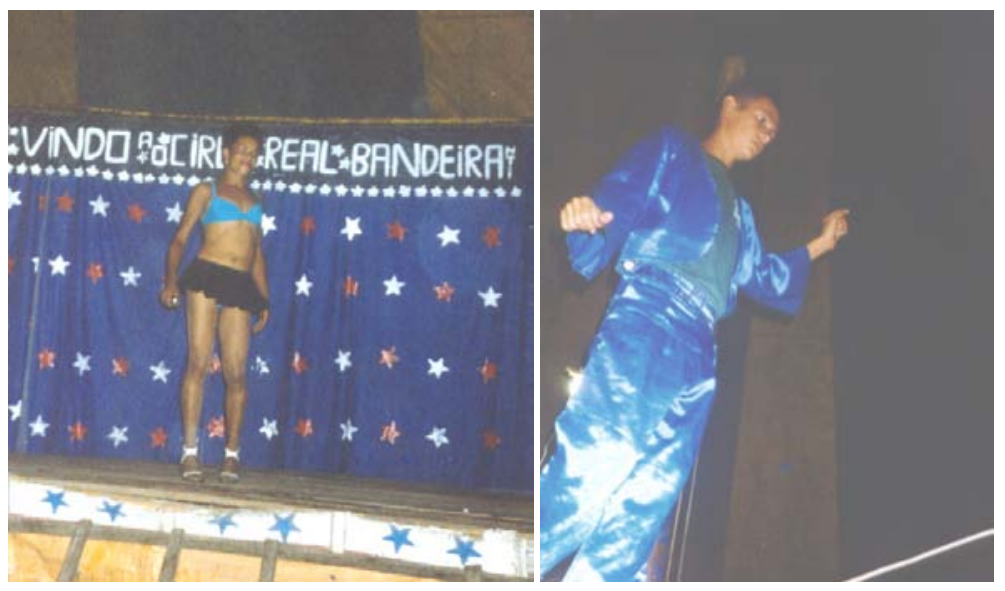

misturando notícias e frases, com efeitos interessantes. A gestualidade, contudo, manteve-se apegada a gestos com fortes conotações sexuais, especialmente nas referências fálicas, acompanhando a disposição do nariz. 



\section{5 \\ Circo Estrela}

\section{O espetáculo}

Corda indiana; Dublagem; Futrica em "Cidade de trás pra frente" e "Namoro na praça"; Dublagem; Monociclo; Malabarismo; Dublagem; Tranca; Paródias com Futrica; Lira.

O Circo Estrela foi contatado a partir do Real Bandeirantes. Ambos estavam na mesma localidade. O Estrela estava chegando à

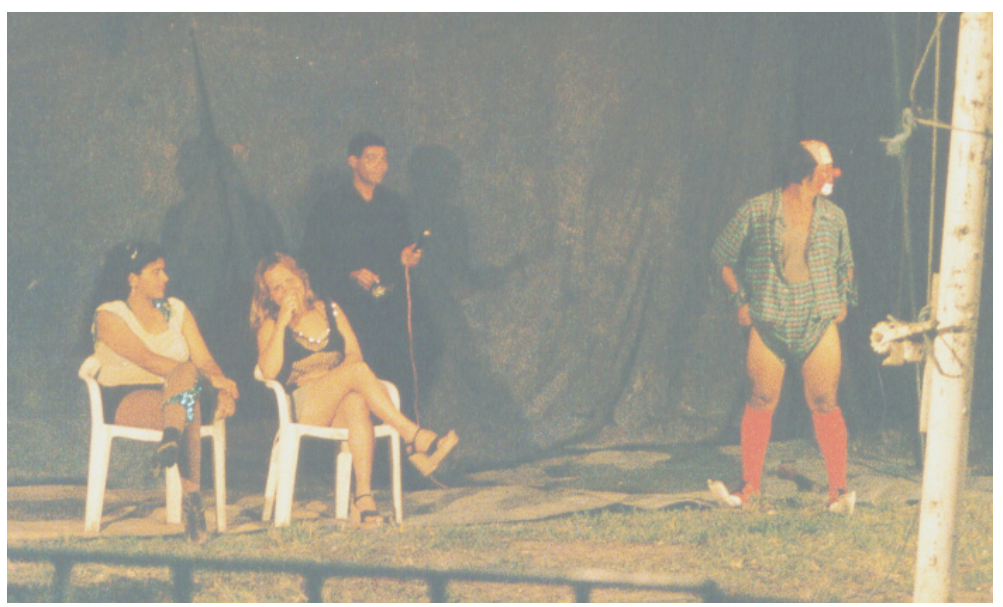


cidade e instalou-se próximo ao centro de Marechal Deodoro-AL. O circo tinha 30 metros de diâmetro, com um único mastro. Não era tão precário como o anterior mas, mesmo assim, as instalações eram modestas. Não tinha palco e os artistas apresentaram-se sobre a grama. Os recursos de iluminação eram deficitários. Os de som, ao contrário, foram suficientes para superar o tumulto da plateia.

O espetáculo não era tão rústico, como o do Real Bandeirantes. Os aparelhos eram construídos em ferro e madeira, porém com acabamento precário. Para não fugir à regra, as dublagens ocuparam boa parte do espetáculo. A exceção ficou por conta do palhaço. No Circo Estrela, Futrica participou de todas as entradas.

\section{Futrica}

Lucélio Leite da Silva, o palhaço Futrica, tinha 27 anos de idade e dedicava-se à arte do palhaço desde os 15 . Teve uma boa performance em cena e não se apoiou apenas no riso das piadas. Apresentou uma mobilidade corporal adequada ao tipo esperto que desempenhou.

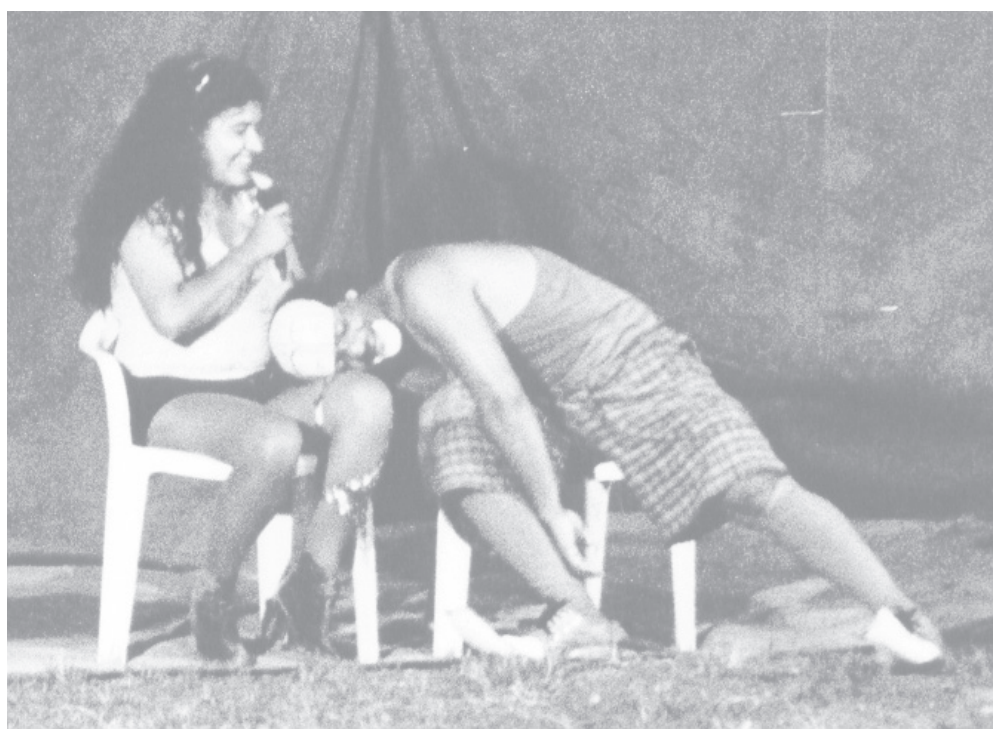




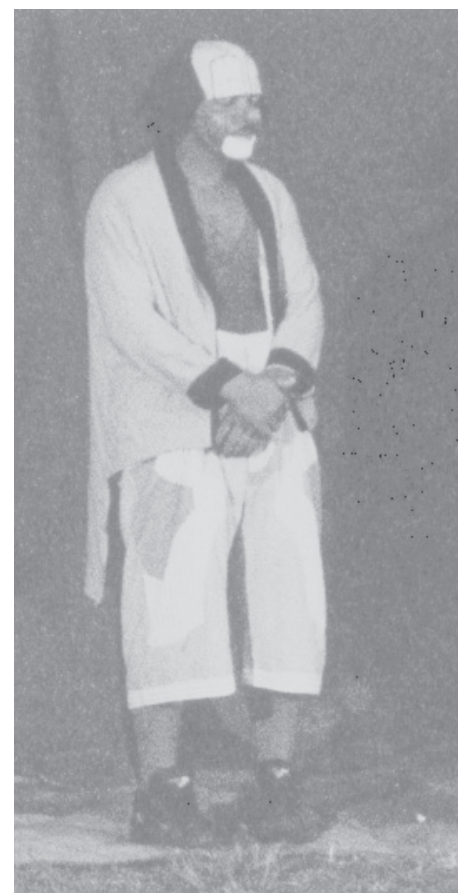

Sua entrada durou cerca de trinta minutos. Após cativar a plateia, foi "costurando" uma entrada à outra ("Cidade de trás pra frente" e "Namoro na praça”, com a música Quando eu estava em Paris etc.).

Futrica entrou no espetáculo acompanhando outros números (Malabarismo e as Trancas), com outra roupa. Para finalizar, parodiou músicas, envolvendo pessoas da plateia. Ele foi a grande atração do espetáculo do Circo Estrela: simpático, cativante, conseguiu trazer o completo relaxamento da plateia. Esquivou-se soberbamente dos gracejos e impropérios que o público lhe dirigiu. Não fez uso contínuo de gestos sexuais, mesmo explorando corporalmente o duplo sentido das piadas, especialmente na "Cidade de trás pra frente", quando o mestre de pista diz o nome dos lugares e o palhaço repete-os às avessas: "Eu passei em Pau d'Alho"; "Eu passei alho no.... ah! Não, arde muito!” etc. 



\section{6 \\ Circo Shalom}

\section{O espetáculo}

Parada de mão; Dança; Monociclo; Pebolim e Real em "Aprender a namorar"; Lira; Dublagem; Pipo; Pebolim e Real em "Caveirão"; Magia; Corda indiana; Facas; Pipo e Pebolim em "A bomba"; Arame alto.

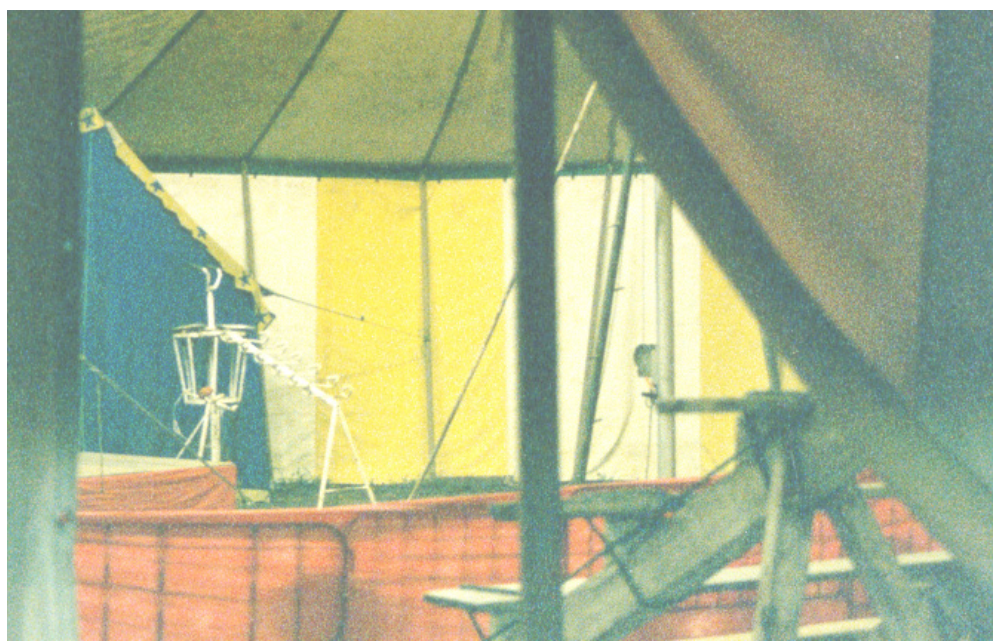


Às margens da rodovia BR-101, em Cruz das Almas-BA, estava instalado o Circo Shalom. Com dois mastros, o pequeno circo alcançava as dimensões de 20 metros x 26 metros. A lona, amarela e branca, era nova. $\mathrm{O}$ espaço de cena dividia-se entre um pequeno palco e um picadeiro, sem tapete.

O espetáculo não fez uso abusivo das dublagens. Elas existiram, sem apelos à exposição do corpo feminino. Prevaleceram, no espetáculo, os números circenses, que foram apresentados com proezas, a exemplo das Paradas de mão e do Arame alto.

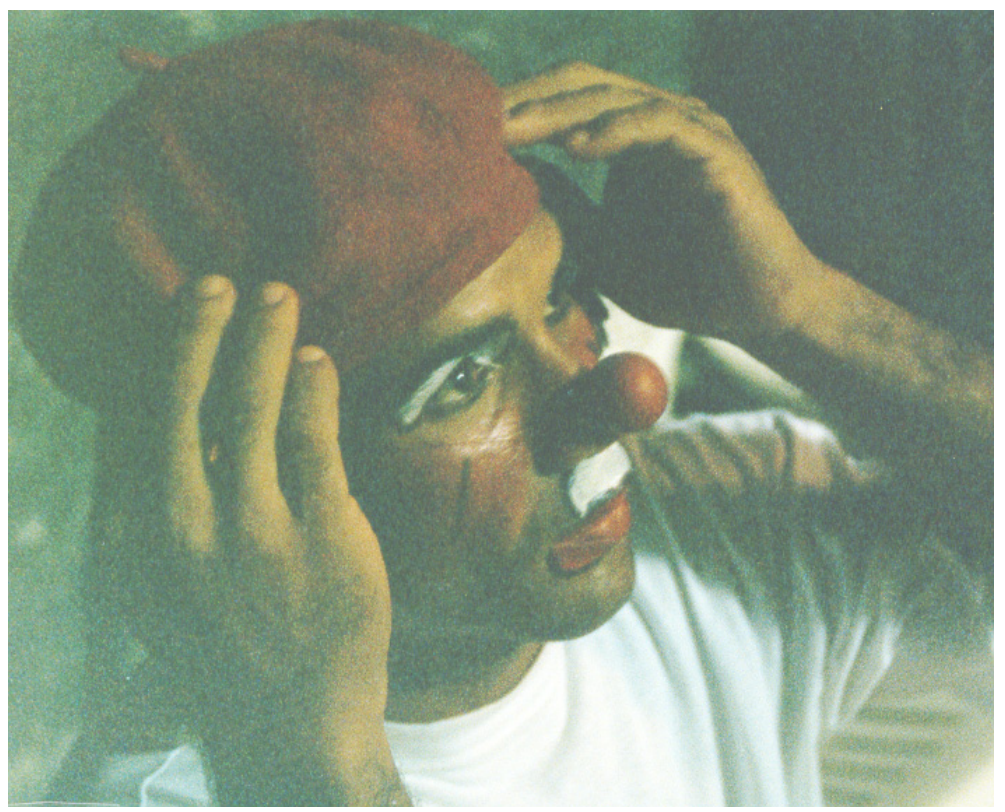

\section{Pipo}

Pipo foi concebido por Cleberson Macedo da Silva, o proprietário do circo. Ele tinha 30 anos de idade e havia cinco anos interpretava o Pipo. Seu traje era bastante vistoso. O artista revelou que nunca teve preferências por ser palhaço, já que sempre se dedicou a números acrobáticos, que continuava a desempenhar. Ele fez a abertura 
do espetáculo com Paradas de Mão. Também era trapezista voador, mas não era possível desenvolver este número em seu pequeno circo. Seu desempenho cênico como palhaço não fez uso de expressões de apelo sexual, observação que se aplica também aos outros dois palhaços da companhia.

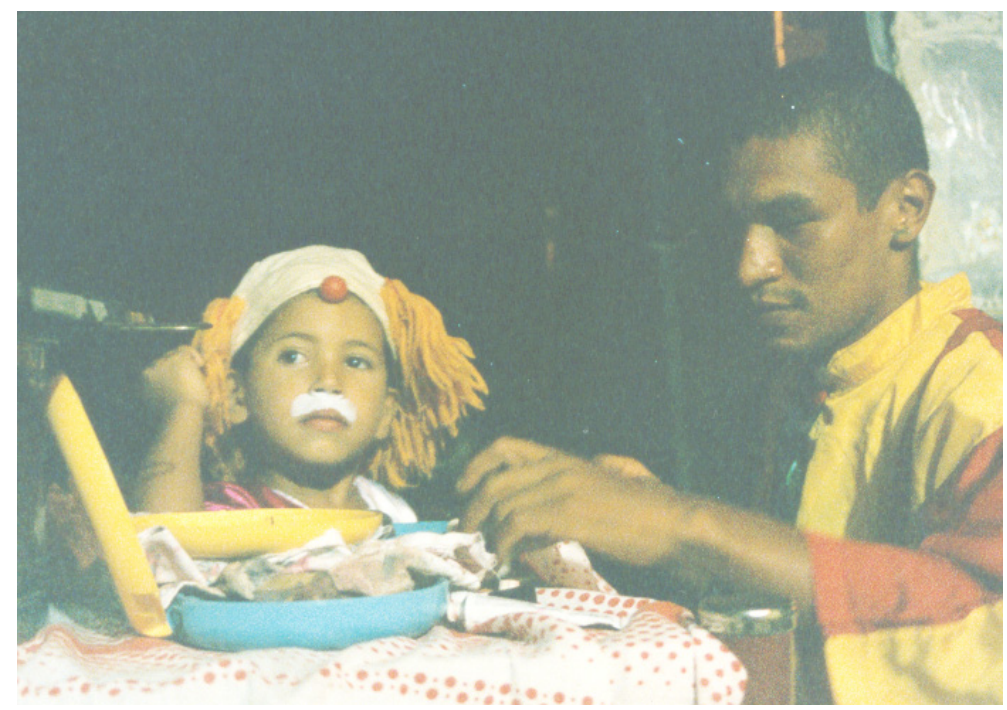

\section{Pebolim}

Cleber Brito da Borda, o Pebolim, tinha, na época, 23 anos. Desde a infância desempenhava a função de cômico. Iniciou na profissão acompanhando o seu pai. O aprendizado, portanto, foi totalmente empírico, no contato constante com o público. Pebolim se transformou em cena. A timidez do cotidiano cedeu lugar a um ator expressivo, com gestual largo e expandido. 


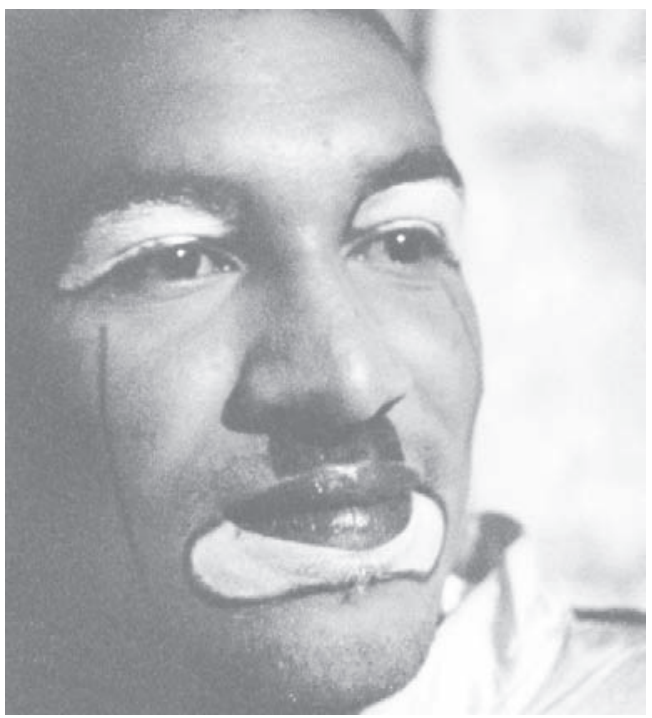

\section{Real}

O menino Lucas da Silva da Borda, aos 5 anos de idade, fazia o palhaço Real. O nome surgiu porque a data de seu nascimento coincidiu com a implantação do Plano Real. Lucas é filho de Cleber e foi desde cedo para o picadeiro porque não havia quem cuidasse do garoto quando o pai estava trabalhando. Real foi bastante seguro em cena. Manteve a atenção aos detalhes, com uma comunicação constante com a plateia. Não tinha uma caracterização firme da personagem. Estava em processo de formação, mas já apresentava uma característica fundamental à profissão: atenção ao tempo do riso da plateia.

No espetáculo noturno de 21 de janeiro de 2000, Pipo e Pebolim levaram à cena as entradas "Aprender a namorar" e "A bomba". $\mathrm{Na}$ última participação, os dois associaram-se ao menino Real e encenaram "O caveirão”. Eles se apegaram ao microfone, apesar das pequenas dimensões do circo. Esse recurso inibiu o desempenho corporal dos artistas. Contudo, mesmo com esse limite, os palhaços 


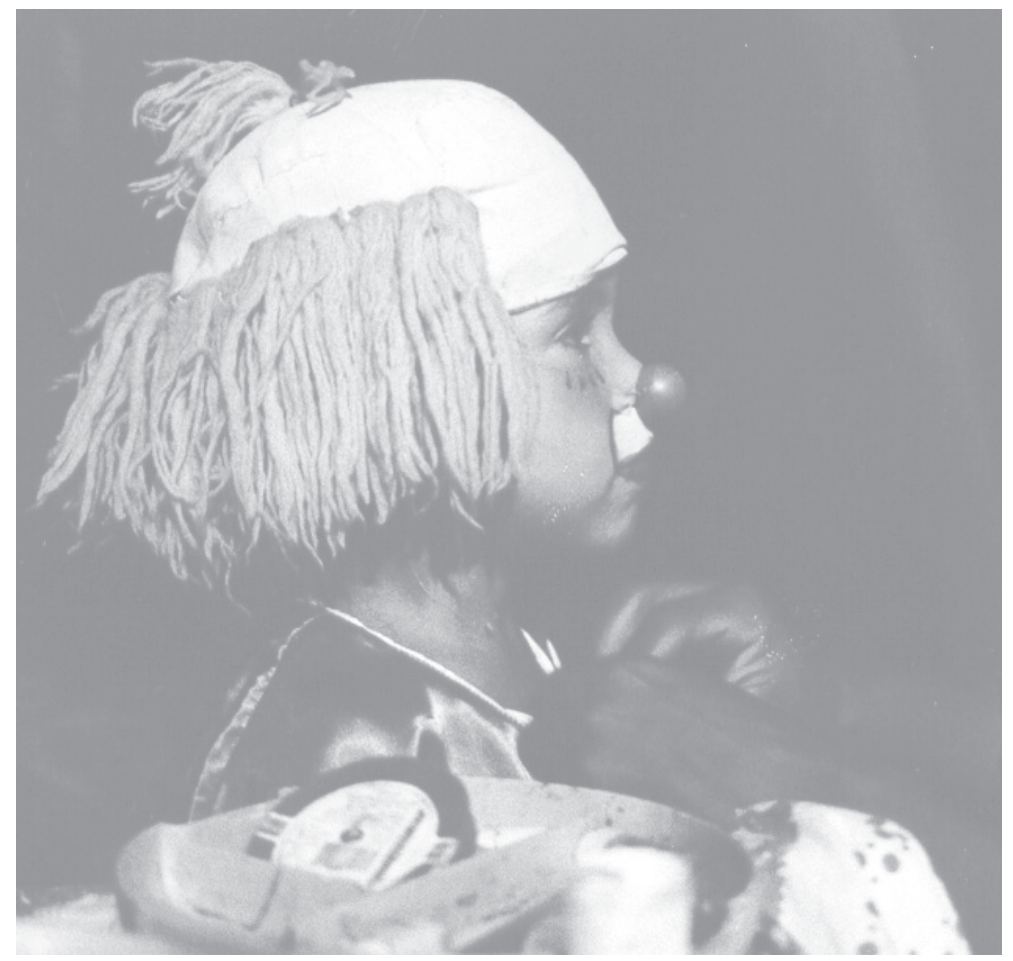

tiveram uma performance precisa. O tempo cômico, por exemplo, foi observado com rigor a todo instante. Ademais, principalmente Pebolim (mais) e Pipo (menos) conseguiram estabelecer um diálogo cênico com a plateia, o que motivou a improvisação a partir dos roteiros básicos das entradas. 



\section{7 \\ Parque Circo las Vegas}

\section{O espetáculo}

Leões; Cacareco em "Equilíbrio de bule e xícaras"; Cão amestrado; Cabra amestrada; Cacareco e Faísca em "Magia com dados"; Magia; Cacareco e Faísca em "Mágico árabe"; Pôneis amestrados; Avestruz; Cesto espacial; Cacareco e Faísca em "Salto mortal com a lata na mão”; Macaca amestrada; Laços e chicotes; Globo da Morte.

O Parque Circo Las Vegas foi visitado em 6 de junho de 2000, na cidade de Cáceres-MT. A companhia apresentava uma característica diferenciada: conjuntamente com o circo, funcionava um número significativo de aparelhos de parque de diversão. O público pagava um ingresso único e tinha acesso aos dois ambientes. Na hora programada, o serviço de som anunciou a paralisação dos brinquedos do parque para o início do espetáculo circense.

A lona do Parque Circo Las Vegas era grande, com aproximadamente 50 metros x 60 metros, nas cores vermelha e branca. Era um circo oval, com cúpula. Em seu interior, como espaço de representação, havia um picadeiro de 13 metros de diâmetro. O público acomodava-se em cadeiras e arquibancadas, que não estavam separadas por cercas. 
238 MARIO FERNANDO BOLOGNESI
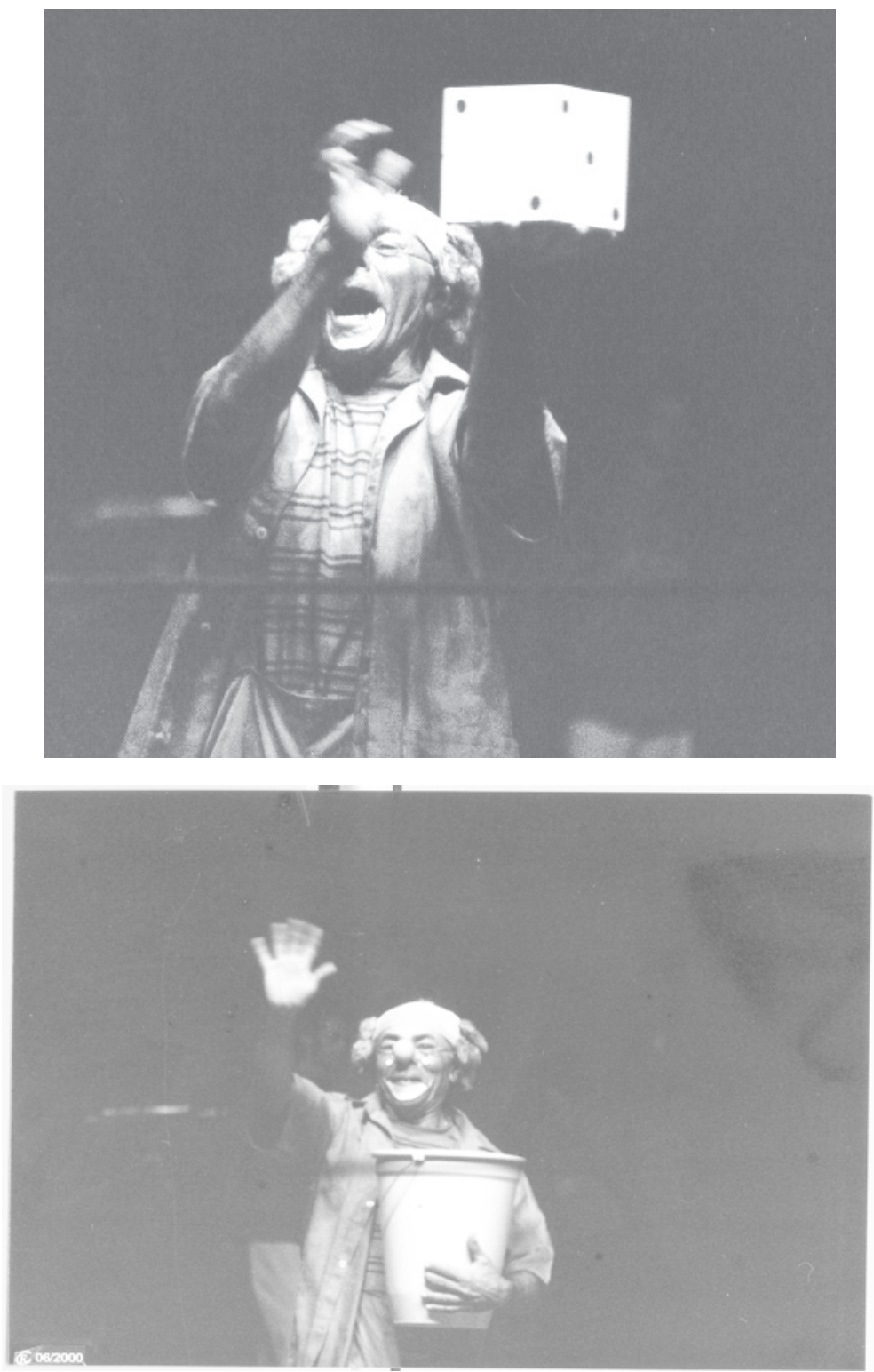
No espetáculo, havia um predomínio de animais, amestrados ou não. Os artistas vestiam-se luxuosamente, porém faltava-lhes a devida presença cênica. A maioria deles era da família proprietária do empreendimento. Os números eram inacabados e simples, do ponto de vista das técnicas circenses.

Os palhaços Cacareco e Faísca fizeram o máximo esforço sem conseguir a retribuição do público. Faltava-lhes personagem e presença em cena. Faísca, principalmente, não conseguiu sequer esconder que estava improvisando na função. Ele entrou no primeiro número do espetáculo como domador dos leões.

\section{Cacareco}

Aluisio Fidele Dias, na época com 52 anos de idade, criou o Cacareco quando tinha 37. Apesar da experiência, seus recursos corporais e vocais deixaram a desejar. Esforçou-se sobremaneira para fazer-se ouvir o que acabou provocando uma voz rouca e monótona. As reprises levadas à cena eram, todas elas, paródias de números circenses. Sua roupa predominantemente vermelha praticamente desapareceu diante da cortina e da lona, também vermelhas. 



\section{8 \\ Circo Rostok}

\section{O espetáculo}

Primeira parte: Bailado homenageando os palhaços; Malabares; Dândis; Parafuso em "Pescaria" e "Cidade de trás pra frente"; Lira; Cães amestrados; Força Capilar; Parafuso em "Pensão da dona Estela”; Globo da Morte.

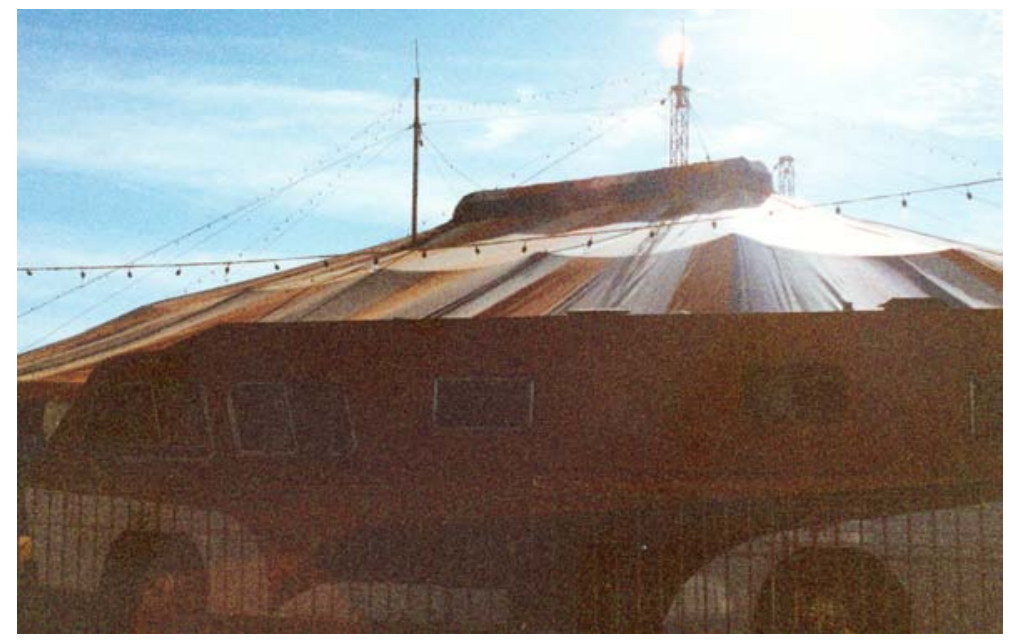




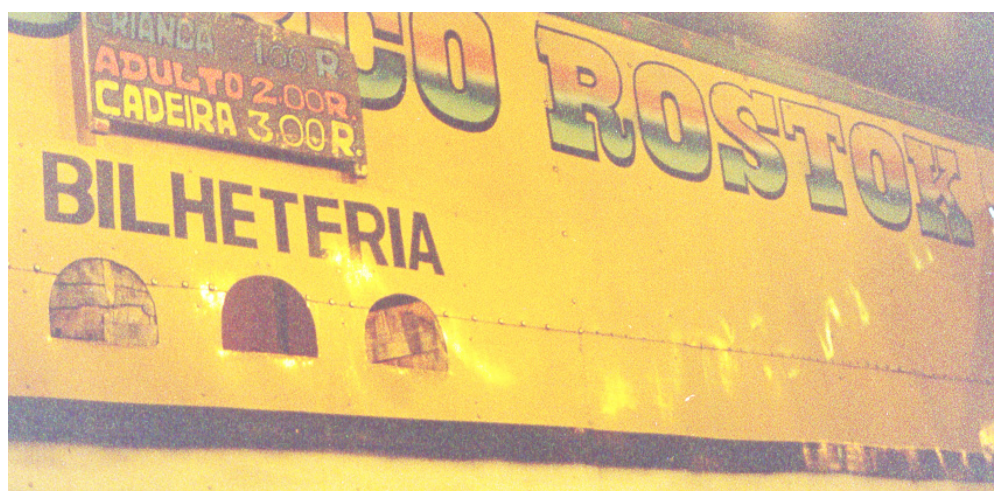

Segunda parte: Leões; Magia Árabe; Arame bambo; Parafuso em "A bomba"; Trapézio Voador.

O Circo Rostok foi visitado nos dias 16, 17 e 18 de junho de 2000, na cidade de Urupês-SP. A lona do circo era nova. O circo media aproximadamente 40 metros x 50 metros. O espaço cênico era composto de um picadeiro cujo tapete surrado destoava do brilho original da lona. Uma cortina de veludo bordô, apresentando um bom tempo de uso, dividia o espaço do espetáculo dos bastidores.

A administração do circo era predominantemente familiar, embora alguns artistas fossem contratados para abrilhantar o espetáculo, o que era o caso do palhaço Parafuso.

Os espetáculos vistos (três noturnos e uma matinê) apresentaram pouquíssimas variações. Havia um predomínio de números circenses, entrecortados por entradas e reprises. A exceção ficou por conta do espetáculo noturno do domingo, quando a segunda parte dele foi substituída pela representação de uma comédia, "Parafuso, empregado do barulho”, roteiro também apresentado por Bebé, no Circo Teatro Bebé.

Os números circenses não apresentaram muitas dificuldades técnicas. Porém, foram executados com esmero e empenho por parte dos artistas. Se não dominavam as mais difíceis proezas acrobáticas ou as mais exuberantes habilidades de equilíbrio ou de malabaris- 

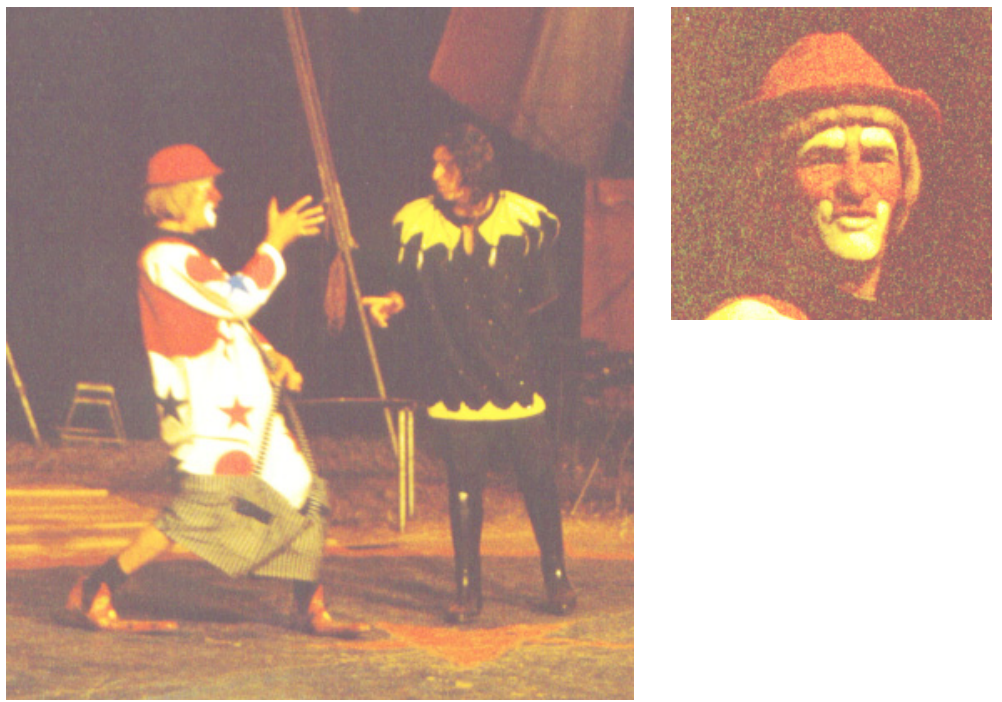

mo, os artistas apresentaram-se com um figurino bem cuidado e com uma energia cênica contagiante, o que terminava por superar as deficiências técnicas.

\section{Parafuso}

Túlio Pereira, o palhaço Parafuso, tinha 51 anos de idade. A personagem foi criada quando o artista tinha apenas 9 anos. Desde então, a personagem/palhaço vem se aprimorando, tanto na vestimenta e na maquiagem como, principalmente, na interpretação.

Parafuso usava uma peruca de cabelos claros, não muito longos, e uma careca. Sobre ela, um chapéu-coco. A vestimenta era composta de uma imensa camisola, com cores, desenhos e frases que se modificavam a cada aparição em cena. Uma quase que minúscula bermuda, presa por enormes suspensórios, cobria a parte do corpo que corresponde à canela. Os sapatos eram grandes e coloridos.

Parafuso demonstrou ser um palhaço predominantemente teatral, que sabe valorizar as ações físicas e as piadas que o roteiro in- 
244 MARIO FERNANDO BOLOGNESI
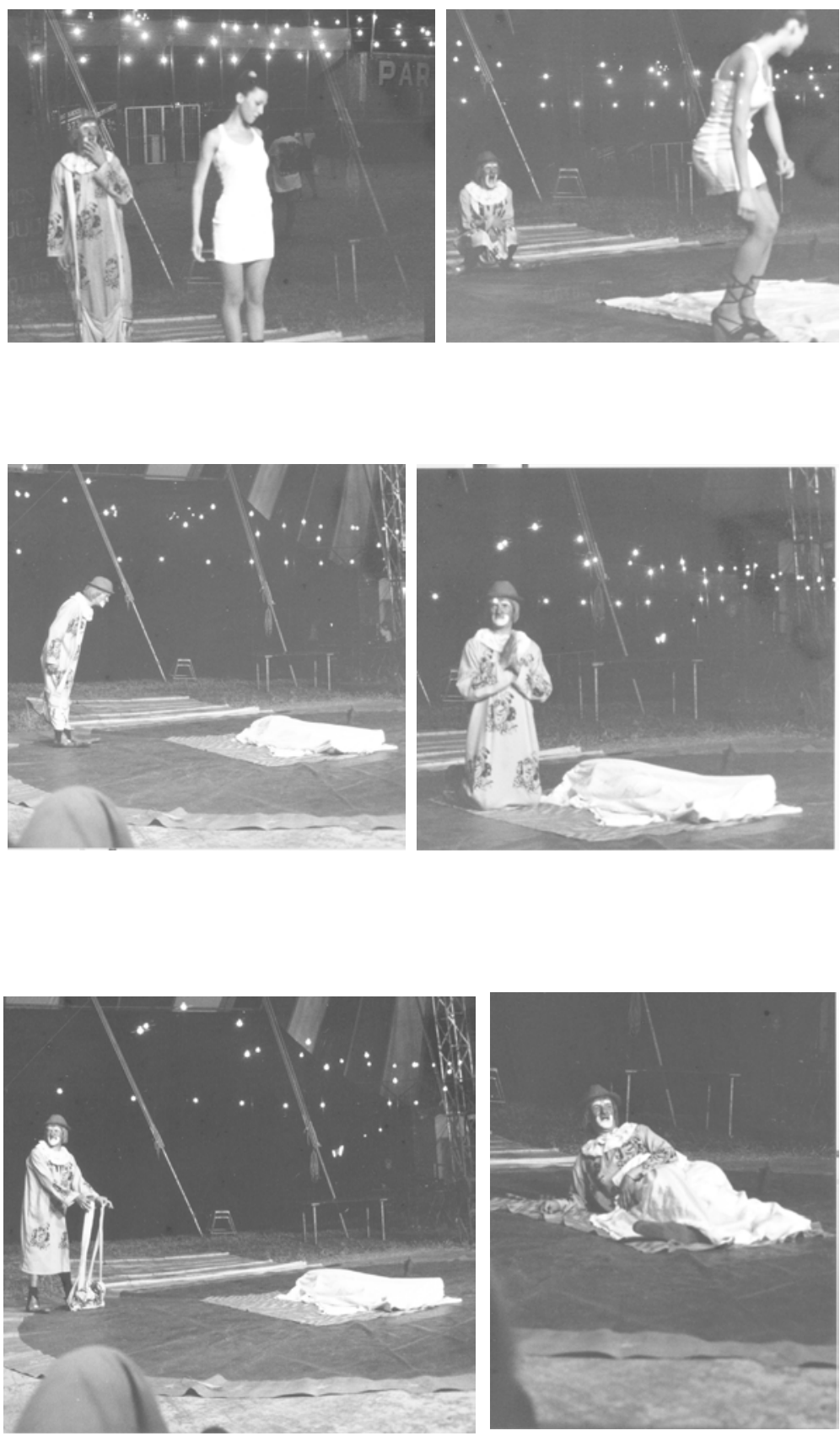
duz. O artista dominava o uso da palavra no picadeiro. Valorizava a palavra ao transferir seus motivos e intenções para as respectivas expressões corporais e faciais. Os gestos, construídos aos poucos, iam evoluindo até ganharem a devida densidade e grandeza com o momento culminante da piada. Personagem rico em gags, ele não as repetia: usava-as com a devida consciência, de forma a retirar delas toda a graça possível. A cada situação, um novo trejeito era trabalhado, enfatizando quase sempre o raciocínio lento da personagem.

$\mathrm{O}$ artista aproveitava as situações que seus companheiros de cena e o público proporcionavam, para uma improvisação livre e descontraída. Em cena, o tempo todo estava atento aos motivos variados que a representação e a interação com a plateia podiam proporcionar. As respostas da plateia eram imediatas e até pareciam sincronizadas e coordenadas a partir de uma batuta invisível, acionada pelo artista. Os próprios artistas coadjuvantes não conseguiam conter o riso diante das facécias do palhaço. Com essas qualidades nem é preciso salientar o seu perfeito domínio do tempo cômico, que possibilitava o relaxamento que o riso provoca e a preparação conflituosa para a próxima gargalhada.

Na próxima página, fotos de Parafuso, em "Pensão da dona Estela".

A comédia apresentada no domingo à noite, "Parafuso, o empregado do barulho", é tradicional do repertório circense. O conflito básico gira em torno da esposa que quer de presente uma minis-

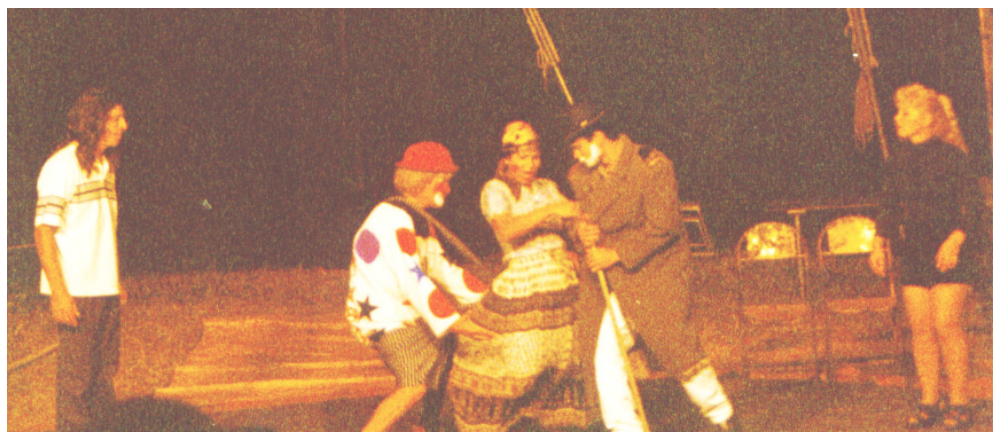




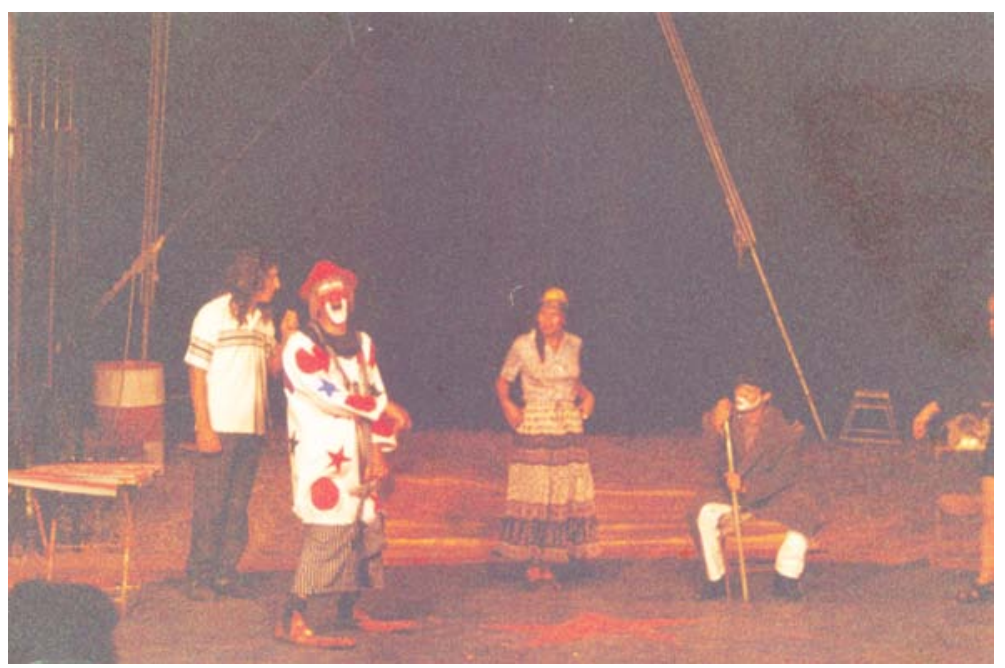

saia que está na moda. $\mathrm{O}$ marido não quer dar o presente à mulher. Ela ameaça deixar a casa e retornar para os pais, que são chamados para opinar sobre a questão. O pai não diz nada e a mãe apoia a vontade da filha. Diante da insistência em não dar o presente desejado, a mulher arruma as malas e vai embora. O palhaço, empregado da casa, é chamado para ajudar a resolver este primeiro conflito. Contudo, ele só traz confusão, em um jogo constante entre carregar a mala da patroa e atender a ordem negativa do marido. Depois de tomar um bofetão da mulher, o palhaço cai e reclama insistentemente seu infortúnio. A mulher abandona a casa.

Sós, em casa, patrão e empregado comentam a atitude da mulher, ora condenando-a, ora sendo compreensivos. O palhaço pontua cada opinião com casos contados e gestos que enfatizam o momento. Porém, com a alternância das ênfases aos comentários sobre a mulher, o palhaço termina se comprometendo com o patrão.

Depois do quiproquó que se forma a partir das opiniões diversas que se alternam, o marido resolve escrever uma carta à esposa, buscando a reconciliação. Desajeitado, o palhaço tenta rabiscar algumas palavras, por sua própria conta. O resultado é desastroso. $\mathrm{O}$ patrão assume a escrita, com as interferências do palhaço. $\mathrm{O}$ texto 


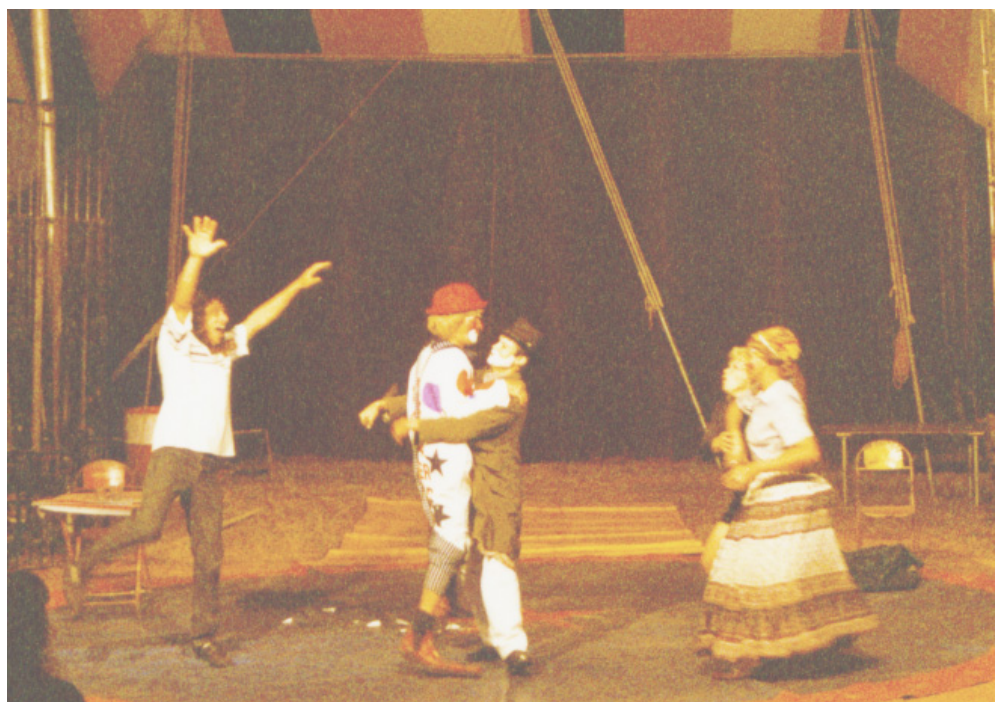

da carta resulta engraçadíssimo, assim como se torna cômico o vaivém em torno da remessa da carta.

A mulher retorna à casa. A comédia finaliza com a reconciliação do casal e com a tentativa do palhaço em conquistar a velha. Está preparado o encontro dos dois mas, no último instante, o palhaço abraça o velho. 



\section{PARA FinAlizAR...}

Esta é uma obra que não se encerra. Seu objetivo é documental e procurou registrar o real estado dos espetáculos desenvolvidos em lonas circenses, portanto itinerantes, em diversas regiões do País. Ela apenas apresentou um microcosmo do universo circense brasileiro, movente e vivo. Algumas companhias deixaram de existir, outras modificaram seus espetáculos, fundiram-se, mudaram seus nomes... A constante transformação é a característica da arte circense.

A amostragem apresentada é suficiente para identificar as diversas modalidades de espetáculos daqueles anos. Além das habilidades circenses, encontravam-se shows musicais, teatro (nas modalidades drama, comédia, esquetes, chanchadas entre outras), show de calouros, dublagens, exibição de animais (domésticos ou não), tourada etc. Até um teatro de pavilhão foi possível documentar. Em todos, no entanto, estava presente o palhaço em diversas participações espetaculares: pilhérias, gags, números de habilidades, paródias musicais, excêntricos musicais, entradas, reprises, esquetes, comédias, só para citar algumas.

Nas diversas regiões do Brasil, o circo desempenha o papel de produtor e difusor da cultura, especialmente para aquelas localidades desprovidas de outros equipamentos culturais. Ele recebe maior aceitação entre as camadas mais pobres da população. Provavelmen- 
te, a pluralidade e a diversidade dos espetáculos venham ao encontro dos anseios populares. O espetáculo circense é plenamente aberto e receptivo às mais diversas e contrastantes manifestações culturais. Ele não se rege pelo estigma da obra enclausurada em si mesma; ele não se deixa levar pelo referencial estético da obra dada à apreciação. O circo incorpora em seu espetáculo o público.

O panorama aqui apresentado pode e deve ser ampliado. É importante dar voz a esses artistas anônimos. Novas tendências são experimentadas pelas artes circenses, o que provoca (e continuará a provocar) mudanças em seu formato. Isso evidencia sua característica mutante. 
SOBRE O LIVRO

Formato: $14 \times 21 \mathrm{~cm}$

Mancha: 23,7 $\times 42,5$ paicas

Tipologia: Horley Old Style 10,5/14

$1^{\text {a }}$ edição: 2009

EQUIPE DE REALIZAÇÃO

Coordenação Geral

Marcos Keith Takahashi 